Вищий навчальний заклад

«Університет економіки та права «КРОК»

\author{
Д. І. Ткач
}

\title{
Журналістика в Угорщині: загальне та особливе
}


УДК 070(439)

T48

\author{
Схвалено Вченою радою \\ Університету економіки та права «КРОК» \\ (протокол № 6 від 25.06.2020)
}

Реиеензенти:

В.А. Денисенко - доктор історичних наук, професор, завідувач

кафедри журналістики, видавничої справи, поліграфії та редагування

Університету «Україна».

О.Г. Таукач - головний редактор наукового журналу «Зовнішні справи»

\title{
Ткач Д.І.
}

T48 Журналістика в Угорщині: загальне та особливе:

Монографія / Д.І. Ткач. - К.: «КРОК», 2020. - 300 с.

ISBN 978-966-170-042-9

У монографії проаналізовано загальні та особливі риси журналістики в Угорщині, розпочинаючи з XVII сторіччя і закінчуючи сьогоденням. Показано, як за ці часи народжувалася, проходила період становлення та розвивалася угорська журналістика. Особливу увагу приділено друкованій пресі, газетам і журналам, наводяться приклади роботи журналістів за різних політичних умов. Досліджено також нові форми журналістики: Інтернет, блоги і твітер в Угорщині та їх вплив на медіасферу. Підкреслено, що протягом усього періоду існування журналістики в Угорщині влада завжди прагнула використовувати 3МІ у власних цілях.

Для студентів, аспірантів, викладачів факультетів журналістики, міжнародних відносин ВНЗ та всіх тих, хто цікавиться історією ЗМІ й Угорщини.

Присвячується моєму кращолу угорськолу другу Надзвичайнолу та Повноважнолу Послу Угорщини Кешкень Ерно, з якил ми розпочинали розбудовувати украӥнсько-угорські відносини у 1991 рощі 


\section{Зміст}

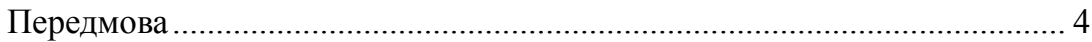

1. Виникнення угорської журналістики .................................................... 7

2. Журналістика у період 1918-1945 pp. ................................................... 31

3. Журналістика у період 1945-1956 років ............................................... 57

4. Журналістика Угорщини під час революції 1956 року.......................... 80

5. Журналістика в Угорщині за соціалістичних часів

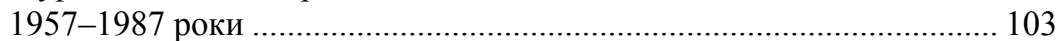

6. Журналістика Угорщини після зміни політичного режиму

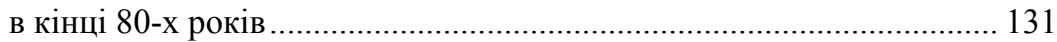

7. Медіаправо в Угорщині на сучасному етапі ...................................... 156

8. Медіаполітика за часів урядування Фідес-УГС в Угорщині .............. 180

9. Електронні засоби масової інформації в Угорщині: сучасний стан . 206

10. Масмедіа Угорщини про проблеми в українсько-угорських відносинах, пов'язані із Законом про освіту .................................... 239

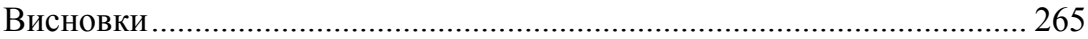




\section{Передмова}

Журналіст працює у сфері комунікації, він є ії органічною складовою, він збирає, узагальнює та передає інформацію загалу. У сфері комунікації (спілкування) беруть участь усі без винятку люди, але тільки журналіст займається цим професійно у вироблених віками формах - журналістських жанрах, призначених для донесення певної інформації споживачам.

Ще ніколи журналісти не були такі важливі для суспільства, ніж в епоху інформаційного вибуху. Ще ніколи не існувало такої нагальної потреби у компетентному, критичному та наочному входженні в цю складну і водночас цікаву професію.

Професія журналіста у всьому світі має загальні риси, вона вимагає глибоких знань у різних галузях, майстерності в аналізі тієї чи тієї ситуації, володіння творчим натхненням та вміння витримувати психологічну напругу, вміння йти на обдуманий ризик при виконанні професійних функцій. У кожній країні цей фах має свою специфіку, ті особливі риси, які притаманні журналісту з урахуванням національного характеру, культури, мови та народних традицій. 3 одного боку, він $є$ представником всесвітньої комунікації, який через засіб масової інформації виходить у люди, своєю творчістю здатний впливати на маси, використовуючи загальноприйняті форми і методи журналістської професії, а з іншого - представником своєї національної спільноти з притаманними йй властивостями, які, безумовно, впливають на нього.

Тому надзвичайно цікавим видається вивчення та узагальнення досвіду іноземних держав у становленні та розвитку журналістики, іï сучасного стану. В нашому випадку ми вибрали Угорщину. Чому саме цю країну?

Як Україна, так і Угорщина $є$ постсоціалістичними країнами, які магістральним шляхом розвитку визначили побудову демократичного суспільства на засадах ринкової економіки. Звичайно, спільна мета $є$ доброю основою для взаємодії.

Обидві країни задекларували свої наміри щодо інтеграції в європейські та євроатлантичні структури. Угорщина надає по- 
стійну допомогу Україні в їі європейських та євроатлантичних прагненнях.

Геополітичний фактор. Сусідні Україна та Угорщина належать до регіону країн Центральної та Східної Свропи. Вони тісно пов'язані спільними інтересами у сфері безпеки у широкому розумінні цього поняття - від військової до екологічної. У розвитку економіки обох країн значне місце відводиться включенню їх у європейську мережу транспортних коридорів - автомобільних, залізничних та водних.

Економіки двох країн у соціалістичну добу були досить взаємопов'язані. Хоч після розпаду РЕВ Угорщина переорієнтувалася на економічне співробітництво із західними країнами, Україна для угорців залишилася досить привабливим партнером. Традиційно розвивається співробітництво прикордонних територій.

Відносини обох країн в історичному минулому не обтяжені конфліктами та проблематичними питаннями. Досить безхмарно розвиваються взаємовідносини і на сучасному етапі.

3 більшості гострих міжнародних питань позиції України та Угорщини практично збігаються або дуже близькі. Це дає можливість зовнішньополітичним відомствам обох країн проводити узгоджену лінію як у міжнародних, так і в регіональних організаціях.

Завдяки цим та іншим факторам, виваженим, скоординованим і цілеспрямованим спільним зовнішньополітичним діям обох країн Україні та Угорщині впродовж 90-х років вдалося створити основу цілісної системи взаємовигідного партнерства та добросусідських відносин. Вона охоплює весь комплекс українсько-угорського співробітництва у всіх без винятку сферах, а для іiі реалізації розроблено дієвий механізм координації діяльності двох держав як на двосторонньому рівні, так і на міжнародній арені.

На жаль, в останні роки стан українсько-угорського співробітництва погіршився через нерозуміння українською владою значення охорони прав угорської нацменшини в Україні. Мається на увазі право на здобуття освіти на всіх рівнях рідною мовою. Останнім часом відбулися переговори між керівниками 
дипломатичних відомств обох країн, які вселяють надію на те, що компроміс буде знайдено.

Угорська журналістика бере свій початок з 1705 року, коли було надруковано першу газету під назвою Magyar Merкúr (Угорський вісник). 3 того часу угорська масмедіа відігравала важливу роль у політичній боротьбі за владу, захисті держави від зовнішніх ворогів, мобілізації населення на вирішення соціально-економічних проблем і т. ін. Усі ці події відбувалися під пильним оком угорської журналістики. Звичайно, кожен історичний період (чи то революції 1848 р., 1919 р., 1956 р., чи то подій, пов'язаних з важливими змінами, які відбувалися 3 угорським суспільством у кінці 1980-х - початку 1990-х рр.) наклав на журналістику свій відбиток. Але незаперечним $є$ те, що угорська журналістика всі ці роки відігравала і відіграє значну роль у суспільно-політичному житті країни. Така сталість - історично сформована угорська традиція.

Дана монографія «Журналістика в Угорщині - загальне та особливе» присвячена дослідженню становлення розвитку та сучасному стану угорської журналістики, починаючи з XVII сторіччя і закінчуючи XXI сторіччям, і є системним дослідженням реакції угорської журналістики на політичні зміни, що відбулися за всі ці часи.

Науково-практичне значення монографії полягає в тому, що в ній типізований матеріал, який може бути використаний у науковій та навчальній роботі з підготовки журналістів та медіадослідженнях. Зібрана й оброблена в монографії інформація не тільки уточнює і доповнює наукові знання про загальну систему преси та журналістики в Угорщині, а й виявляє особливості iii становлення, розвитку та сучасного стану.

Монографія може бути цікавою для вчених-унгарістів, дослідників зарубіжних масмедіа, журналістів-міжнародників. Робота може бути використана при підготовці лекцій з курсів «Історія зарубіжної журналістики», «Міжнародна журналістика», «Медіаправо», «Масова комунікація та інформація» для підготовки фахівців у галузі «Журналістика». 


\section{Виникнення угорської журналістики}

Для того щоб зрозуміти, на якому історичному тлі виникла угорська журналістика, зробимо короткий екскурс у ті роки, коли вона зароджувалася.

У 1703 році Ференц Ракоці II підняв повстання проти імпеpiї Габсбургів за незалежність Угорщини. 1 травня 1711 р. повстанська армія капітулювала під м. Сату Маре. У цей же день була укладена угода про припинення антигабсбурзького повстання. У місті Сату Маре іії підписали головнокомандувач військ Ференца Ракоці граф С. Каролі та генерал угорського імператора П.І. Пальфі.

Після Сатмарського миру Угорщина знову ввійшла до складу імперії Габсбургів.

Державні збори могло створювати закони спільно з імператором. Адміністративні завдання виконувалися самостійними угорськими наказами, Радою намісництва, Угорською Королівською Казною і Угорською Королівською Канцелярією. Однак більшість важливих для країни рішень народжувалися у вищих органах імперської адміністрації.

У 1711 році вступив на престол король Угорщини Карой (Карл) III. Він не мав синів, тому розпорядився, щоб після його смерті трон перейшов його дочкам, які повинні були успадковувати країни імперії в неподільному вигляді. На Державних збоpax (угорський парламент) 1722-1723 рр. угорське дворянство затвердило успадкування по жіночій лінії і висловило згоду на те, щоб Угорщина та її суміжні частини нероздільним і невіддільним чином були пов'язані з іншими провінціями імперії (Прагматична санкція). 
Після смерті Карла III війська прусського короля Фрідріха II зайняли Сілезію - одну з найбільш промислово розвинених провінцій імперії Габсбургів. Королева Марія Терезія на Пожоньских (Братислава) Державних зборах звернулася за допомогою до дворянства, яке проголосувало за надання в армію новобранців і за сплату військового податку. Завдяки війні за австрійську спадщину, потім семирічній війні (1740-1748 рр.; 1756-1763 рр.) вдалося запобігти втраті подальших територій.

Незважаючи на епідемію, чисельність населення в період 1720-1787 років зросла вдвічі й до кінця сторіччя досягла 10 мільйонів осіб. Щільність населення в північних і західних районах була набагато вищою, ніж на територіях, відвойованих у турків. Значна частина населення жила в селах або сільських містечках.

XVIII століття в Угорщині було добою економічного підйому. Вітчизняними посередниками під час поширення ідей освіти були угорські студенти, які повернулися додому після навчання в нідерландських, італійських і німецьких університетах. Вплив освіти, проте, виявлявся головним чином серед аристократії та інтелігенції. Для угорської науки і культури цієї епохи поки ще характерне вживання латини, але поступово вже ширилася потреба в поширенні угорської мови. Вплив французьких енциклопедистів виявлявся і в літературі, присвяченій опису країни. Нова система виховання «Ratio Educationis» (1777 р.), що передбачала єдину організацію навчання в дусі освіченого абсолютизму, була введена монархом не у вигляді закону, а наказним шляхом.

Коли зійшов на престол після Марії Терезії Йосиф II, він мав намір урізати владу дворянських станів. У роки свого правління він увів низку прогресивних реформ. У той же час через видання декрету про введення діловодства в імперії виключно німецькою мовою (1784 р.) і скасування місцевого самоврядування в Угорщині Йосип II втратив і більшість своїх угорських прихильників.

Леопольд II, що став його наступником, упорядкував зовнішньополітичне становище імперії і на Державних зборах 1790-1791 років - уклав угоду з угорцями. Ференц I, який зай- 
няв трон після Леопольда II, скасував усі прогресивні закони свого попередника щодо освіти.

У 1795 році відбулася розправа з угорським якобінським рухом, що ставив собі за мету проведення громадських реформ i досягнення незалежності країни, - це на три десятиліття поклало кінець реформістським рухам.

Ференц I після 1812 року не скликав Державні збори і керував країною наказним шляхом. Після видання в 1821-1822 роках указу про внесення військового податку сріблом по країні прокотилася нова хвиля протесту. Правитель придушив цей рух, але на 1825 рік скликав Державні збори. На цьому зібранні граф Іштван Сечені заявив про пожертвування всього свого річного доходу на створення Угорського Наукового Товариства, Академії. Цей символічний жест поклав початок доби реформ.

Важлива мета політичної еліти полягала в економічній модернізації країни та впровадженні буржуазних реформ. Опозиція, що виступила проти реформ, уперше заявила про себе як самостійна група на Державних зборах 1832-1836 років. Її найбільш видатні особистості - Ференц Кьолчеі, Ференц Деак, Міклош Вешшелені, Лайош Кошут - хотіли об'єднати справу громадських і економічних перетворень з ідеєю самовизначення нації. Створенням у 1846 році Консервативної, потім у 1847 році Опозиційної партії було розпочато формування політичної партійної системи в Угорщині.

У цю добу стрімко зростала кількість газет і журналів. Становленню культури на угорській мові сприяло проведене в першій половині сторіччя оновлення угорської мови. Поширенню єдиної відродженої мови сприяли оголошення угорської мови державною мовою (1844 р.) і збільшення кількості газет та книг.

У середині 19-го століття Угорщина разом з Трансільванією та військовими прикордонними областями налічувала десять мільйонів жителів, у тому числі тільки чотири мільйони угорців. Значна частина міського населення складалася 3 німецькомовних жителів. У вільних королівських і сільських містах в значній мірі збільшувалася частка єврейського населення.

Після спалаху взимку та навесні 1848 р. європейських революцій до влади в Угорщині прийшла ліберальна реформістська 
опозиція. Під керівництвом графа Лайоша Баттяні був сформований перший угорський відповідальний уряд і сформульовані найважливіші закони (звільнення кріпаків, народне представництво, рівність перед законом, свобода друку, рівність віросповідань і т.д.). Усі ці закони були затверджені Фердинандом V. У вересні 1848 року в Угорщині почалася Революція. Лайош Баттяні був призначений головою Ради міністрів, після його відставки виконавчою влада перейшла до Комітету оборони Угорщини, який був обраний Державними зборами.

У середині грудня 1848 року збройні сили Австрії розпочали наступ, на початок січня 1849 року імператорська армія зайняла більшу частину Угорщини. Навесні 1849 року революційна армія відтіснила імператорські війська до прикордонних областей. Після проголошення незалежності Лайош Кошут став верховним правителем Угорщини і сформував уряд Семере. Австрія звернулася за військовою допомогою до царської Росії, i до середини серпня революція була розгромлена збройними силами, які в два $з$ половиною рази перевищували армію повстанців.

Над ватажками й учасниками революції була вчинена жорстока розправа: в Пешті був страчений голова Ради міністрів Лайош Баттяні, а в Араді - тринадцять вищих офіцерів угорської армії. Загалом було страчено 145 революціонерів. У 1850 році стан облоги змінився на більш лояльну буржуазну монархію, ця влада від імені Міністра внутрішніх справ Олександра Баха отримала назву «бахівської системи».

Усі спроби революціонерів, що ставили собі за мету досягнення національної незалежності, закінчилися провалом. За підтримкою порядку стежили армія і жандармерія. Були введені австрійський кримінальний кодекс, система оподаткування й остаточно скасоване кріпосне право (1853 р.). За десять років сума прямих податків зросла в чотири рази. У період 1849-1867 рр. завдяки імперській програмі модернізації збільшилася довжина залізничних ліній і зросла кількість зарубіжних інвестоpiв.

У 1859 році французький імператор Наполеон III вступив у союз з П'ємонтським герцогством і в битві під Сольферіно 
розгромив імператорську і королівську армії. Ця поразка вирішила долю бахівської системи. Австрійський імператор Франц Йосиф I восени 1860 року вже обіцяв відновити конституційне правління, потім у 1861 році скликав угорські Державні збори, однак, оскільки обидві його партії прагнули до відновлення стану 1848 року, Державні збори було імператором розпущено.

Нова система правління - «Провізоріум» - повернулася до абсолютистської форми. Найбільш авторитетний угорський політик Ференц Деак навесні1865 року заявив у газетній статті, що нація готова погодитися із законами 1848 року, якщо їх буде гарантувати імператор Франц Йосиф.

Улітку 1866 року вибухнула війна Пруссії та Італії проти Австрії. Австрійська армія зазнала катастрофічної поразки від прусського війська під Кеніггрецем. Деак і його прихильники, однак, і після поразки не збільшили своїх вимог, та в 1867 році був укладений так званий компроміс - Австрійсько-угорська угода.

Новоутворена після укладення компромісу нова державна формація представляла собою союз двох рівноправних держав: Австрійської імперії та Королівства Угорщини. Королівство Угорщина об'єднувало всі території історичної Угорщини. Трансільванія возз'єдналася з Угорщиною, військові прикордонні провінції були скасовані. У 1868 році була досягнута хорватсько-угорська угода. Обидві половини імперії мали своє законодавство, уряд, адміністративне управління і правосуддя.

Кількість промислових підприємств за сорок років зросла в одинадцять, а число зайнятих на них працівників - у шість разів. 3 галузей промисловості в найбільш сприятливому становищі перебувала харчова промисловість, у гірській промисловості значно збільшився видобуток вугілля і залізної руди. У галузі машинобудування особливо важливу роль відігравало транспортне, харчове та сільськогосподарське обладнання.

Економічний розвиток і зростання потреб у галузі освіти перетворили й зовнішній вигляд країни. Завдяки залізничним лініям скоротилися відстані. Зовнішній вигляд і структура Будапешта, який об'єднав у собі в 1873 році Буду, Пешт і Обуду (Стара Буда), наслідували приклад європейських міст. 
Питома вага угорської нації завдяки добровільній асиміляції міського німецького та єврейського населення значно збільшилася і в 1910 році, якщо не брати до уваги Хорватію - вже перевищувала половину населення. Приблизно по десять відсотків населення становили німці й словаки, шістнадцять відсотків румуни, два з половиною відсотка - серби.

Національний закон 1868 року визнав політичною нацією тільки угорців, офіційною державною мовою стала угорська. У той же час у внутрішніх справах самоврядування, у внутрішньому листуванні, на нижчих рівнях адміністрації і в судах допускалося користування мовою інших національностей. Держава повинна була подбати про те, щоб кожна нація могла отримувати початкову та середню освіту рідною мовою. Приватні особи, муніципалітети й церкви могли створювати національні школи, культурні та господарські об'єднання.

28 червня 1914 року в Сараєво було вбито спадкоємця престолу Австро-Угорської монархії ерцгерцога Франца Фердинанда і його дружину. Через місяць після сараєвського замаху 28 липня Монархія оголосила війну Сербії. До середини серпня у війну вступили Росія, Німеччина, Франція й Англія.

У 1916 році війська Монархії були відтіснені новим наступом російської армії. Під впливом цих подій Румунія також оголосила війну Монархії, і їі війська вторглися в Трансільванію. Об'єднані збройні сили Німеччини й Австро-Угорщини зупинили наступ російської армії, завдали важкої поразки Румунії та окупували більшу частину країни. У 1917 році Росія через революцію вийшла зі складу воюючих сторін. Ця перевага, однак, незабаром була компенсована втручанням Сполучених Штатів Америки на боці країн Антанти. У боях війни економічні та людські ресурси Монархії поступово виснажувалися. Після настання жовтня 1918 року Монархія змушена була підписати в м. Падова угоду про перемир'я. Через кілька днів Міністр об'єднаних збройних сил оголосив про розпуск загальної армії.

У ніч з 23 на 24 жовтня була створена і Національна рада Угорщини, на чолі якої стояв граф Міхай Каройї - єдиний послідовний прихильник антивоєнної політики. Історія преси - це частина політичної та літературної історії нації. Ширше: історія 
культури, але водночас і більше - особлива якість. Преса - це особлива інституційна система, особлива функціонуюча громадська думка та рефлексивна структура, засіб масової комунікації.

У ХІХ столітті історію преси розглядали лише як допоміжну науку історико-літературних досліджень. Однак спробуємо визначити те, що насправді робить пресу конкретною інституційною системою, а також розкрити функціонування та історичний розвиток цієї конкретної інституційної системи.

Перший угорський періодичний журнал Mercurius Hungaricus був започаткований через два роки після того, як найстарша газета у світі, попередник Wiener Zeitung, побачила світ. Віденська газета, як й інші газети, дозволені та створені європейським абсолютизмом того часу, знаходилася під безпосереднім впливом імператора та його уряду. Саме він війну Ракоці за незалежність оголосив державною таємницею із забороною щось про неї писати в газетах. Для протидії цій імперській пропаганді було створено Mercurius Hungaricus, з другого випуску - Mercurius Veridicus ex Hungaria. Це була газета партії Ференца Ракоці Другого, лідера антигабсбурзького руху в Угорщині початку XVIII ст., і обраного Принца Трансільванії. Це видання було частиною опору Австрійській імперії (1703-1711 pp.) [1].

314 квітня 1705 року газета вийшла в світ, відразу ставши офіційним органом визвольної боротьби Ракоці, яка до того моменту тривала вже два роки. Видавалася вона угорською мовою для угорських читачів, а також на латині, виключно для зовнішньополітичних цілей. 3 періоду 1705 по 1710 рр. було випущено шість друкованих та рукописних примірників. 3 січня по травень 1710 р. було започатковано регулярний щомісячний випуск видання.

Газета зазвичай публікувала звіти про війну на п'яти сторінках. В Угорщині та для угорських читачів вийшли ще дві газети латинською мовою. На той час у країні читацька аудиторія була латинсько- та німецькомовною, і ці газети також слугували для освітніх цілей. Це для того, щоб протестантські студенти, які навчалися в університетах німецькою мовою, змогли познайомитися 3 життям країни. Студенти з матеріалів преси могли 
ознайомитися з географією, політологією, історією та мовознавством.

З 1730 року розпочався випуск газети Buda, а з 1765 року Preßburger Zeitung, перша газета, що постійно виходила (в той же час газета, яка проіснувала найдовше в історії Угорщини: 3 1764 р. по1929 р.)[2].

На той час газети повідомляли новини без оцінок, коментарів чи навіть спроби групувати їх за темами, що робило газети не цікавими для вдумливого читача.

Народження преси країни та угорської нації у складі імпеpiї Габсбургів відбулося в той час, коли цей референтний газетний тип уже зазнавав трансформації по всій Європі. Преса перейшла від простого передавача інформації до аналітичного, дискусійного матеріалу, який формує думку.

Була ще одна важлива передумова трансформації, що призвела до розквіту преси в імперії Габсбургів, а саме - трансформація цензури. Цензура тривалий час перебувала в руках католицької церкви, точніше ордену єзуїтів. Під час правління Марії Терезії було реорганізовано придворний цензурний комітет без участі єзуїтів.

Видатну роль у створенні угорської журналістської школи того періоду відіграв А.Л. Шльозер (A.L. Schlözer). Вихователь великого покоління державних діячів та науковців німецького Просвітництва, сам видатний історик і критик, він не лише навчав мистецтву читання газет у дусі Просвітництва, але й інтерпретував правила та можливості журналістики й редакційної роботи. Наріжним каменем його поглядів було те, що газетам слід прагнути писати правду, а журналіста не можна звинувачувати, якщо написане буде неправдою. Журналіст не може гарантувати правдивість своїх новин, але повинен збирати та розслідувати їх. Правильна поведінка - це дивитися на газету як на збірку новин і думок, які надходять з різних галузей та різних джерел[3].

У 1780 році Матяш Рат заснував Magyar Hírmondó, яка виходила двічі на тиждень щосереди і щосуботи. Цей вісник не відповідав формальним ознакам Віденського офіційного вісника та угорських і німецьких газет, а скоріше, був схожий на журнал, 
маючи вигляд книги. Рамки референтного газетного типу були замінені вільнішим порядком новин та повідомлень залежно від характеру матеріалу. За перший рік існування у нього було 320 абонентів, переважна більшість 3 великих міст, у наступні роки це число зросло до 4500. У 1788 році Magyar Hírmondó припинив свою діяльність[4].

II. Йосип у 1780 році скасував газетні привілеї в Угорщині, тому Відень тимчасово став центром видавництва друкованих видань угорською мовою.

Початок угорськомовної журналістики також пов'язаний 3 Віднем, у 1786 році був надрукований Magyar Musa як додаток до Magyar Kurir. Це був перший часопис, виданий угорською мовою. Його публікували двічі на тиждень. Зміст складали вірші, але, крім них, друкувалися доробки відомих письменників тієї доби[5].

3 лютого 1787 p. Magyar Hírmondó також опублікував у Братиславі додаток угорською мовою під назвою Magyar Musa. В основному він друкував статті, літературні дослідження та огляди книг.

У 1806 р., окрім єдиного у Відні Magyar Merkurius, у Пешті стала видаватися газета Hazai Tudósítások, але за тієї умови, що вона може публікувати лише вітчизняні новини. Її редактор Іштван Кульцар був письменником, який створив колектив журналістів для спільної праці. Незважаючи на свій літературний інтерес, він заснував не журнал, а газету, оскільки вважав, що 3 усіх видань газета працює якнайкраще і швидше. Через два роки після заснування газети повітова рада надала дозвіл на публікацію в газеті закордонних новин. 31808 р. назва газети змінилася на Hazai és Külföldi Tudósítások, потім з 1840 р. вона діяла під назвою Nemzeti Újság. У 1818 р. у неї було 800 підписників[6].

Угорські репортажі відігравали важливу роль у мовних освітніх рухах початку століття, включаючи битву за оновлення мови, відому в угорській літературній та мовній історії як аркадський позив, це була фактично перша реальна дискусія в пресі в масштабі країни.

У 1825 році граф Юзеф Дессеффі започаткував журнал 
Felső Magyar Országi Minervá. Цей квартальний часопис набрав 403 передплатники у перший рік, через три роки їх було лише 278. На той момент він був одним із прибічників свободи преси, хоч із елементами консерватизму. В 1828 році граф Іштван Сечені друкувався в журналі, іронічно висміюючи консервативні погляди частини авторів часопису. В свою чергу, пропонував слідувати так званому англійському стилю, а саме Edinburgh Revue. Цікавим є те, що угорські журнали наслідували цю модель протягом наступного півстоліття[7].

Редактори іншого журналу, Пал Семере та Ференц Кольцей, дали назву Élet és Literatura (пізніше змінено на Muzárion, 1826$28,1829,1833)$. Цей часопис публікував представників еліти молодої літератури. Публікація на його сторінках досліджень на теми критики, естетики та історії дає право його назвати творцем угорської романтики.

Літературні альманахи, що з'явилися в Угорщині як популярний тип видання, також відігравали роль у вкоріненні журнальної літератури, і вони забезпечували читання художньої літератури для різної публіки, насамперед для читачок-жінок. Найважливішим і найвимогливішим представником цього виду літературного видання була Aurora під редакцією Каролі Кішфалуді у Пешті з 1821 року.

Граф Іштван Сечені почав процедуру ліцензування Jelenkor газети у 1829 році, у 1832 році вийшов перший примірник цього видання. Jelenkor символізує початок нової ери в історії угорської преси: вона спочатку видавалася в традиційній формі 3 двома колонками, але 31836 р. - за наполяганням Сечені - перейшла до великого англійського триколонного газетного формату. Про суспільний попит на видання говорить досі небачена кількість примірників: у 1835 р. передплачувало понад 3000, а в 1837 р. - понад 4000[8].

Масмедіа, яку видавав Сечені, була заснована на угорській традиції преси, але приблизно у той самий час була започаткована спеціальна газета, що виросла, зокрема, з рукописної кореспонденції угорської опозиції. Це започаткував Лайош Кошут у Парламентських звітах (1832-36). Ідея парламентської газети була озвучена в 1830 році, але через цензуру не була здійснена. 
Кошут випустив рукописну газету, яка не підпадала під цензуру. Він зі співавтором Йосифом Йосифом створили «кабінет», в якому 25 бідних, а пізніше, 40 бідних студентів-юристів копіювали газету, це саме і була кількість передплачених примірників.

Улітку 1833 р. Кошут купив друкарський прес у Відні та виготовив 69 літографованих копій газети. Влада негайно забрала прес, оштрафувала Кошута, але пообіцяла почати процес на отримання дозволу на друк.

Кошут розпочав процес отримання дозволу на друкування парламентської газети і таки добився її видання. У 1836-37 роках менше, ніж за рік, газета, яка вийшла всього лише у 23 випусках, набувала все більшого поширення: вона збільшила кількість передплатників із стартових 51 до 160.

На початку 1837 р. Л.Кошут був заарештований за політичну діяльність і ув'язнений на три роки за державну зраду. 3 в'язниці Кошут був звільнений у 1840 році. Народ зустрів його захоплено: 10000 форинтів були зібрані за передплатою й піднесені йому у вигляді національного подарунка.

Після звільнення і відновлення здоров'я, що погіршилося в результаті поганих умов утримання в ув'язненні, в січні 1841 року Кошут був призначений головним редактором Pesti Hírlap - нового видання, що згуртувало навколо себе ліберальних і радикальних демократів, які прагнули до національного визволення.

Pesti Hírlap зосередився на серйозних, хвилюючих, пристрасних публікаціях та повітових доповідях, закордонні новини також друкувалися у журналі, а столичні публікації стали популярними завдяки їх авторам. У побутовій та соціальній сферах газета друкувала гострі матеріали, тим самим викликала незадоволення влади. Кошут також змінив звичний бароковий публіцистичний тон, замінивши його живою, авторитетною мовою, з використанням інструментів ораторського мистецтва. Кошут жив виключно для своєї редакційно-публіцистичної праці, віддаючи всю свою енергію цій діяльності.

Pesti Hírlap швидко завоював читацьку аудиторію як у Пешті, так і в провінції. Починаючи з тиражу 60 примірників, че- 
рез чотири роки, на початку 1844 року, газета вже друкувала 5200 екземплярів[9].

Стурбований успіхами Кошута, австрійський уряд організував проурядову угорську газету Világ, яка конкурувала 3 газетою Кошута. Однак такі дії тільки посилювали інтерес до нового лідера угорського національно-визвольного руху і підтримку його з боку народу. Те, що саме Кошут очолив революційне крило угорської політики, визнав сам граф Сечені, який стверджував, що виступи Кошута неминуче призведуть до революції.

Полемізуючи з Кошутом, Сечені в 1841 р. написав блискучу за формою і змістом статтю «Народ Сходу». Починаючи хронологічний відлік від азіатської прабатьківщини угорців (звідси й назва статті), Іштван Сечені далі плавно перейшов до сучасного стану Угорського королівства: «У руках Лайоша Кошута щотижнева газета (...) - не що інше, як саме гостра зброя, але вона - і в цьому-то вся біда - не очистить Батьківщину від того шлаку, який нагромадився в іiї організмі, а вб'є іiі і таким чином приведе угорців не до слави, а до загибелі. (...) автор діє прямо за французьким зразком. Цей зразок є не що інше, як той шлях, по якому йшли, починаючи від Мірабо, Демулен, Дантон, Сен-Жюст, Марат, Робесп'єр, аж до героїв сучасної французької пропаганди: Ламенне, Пера, Анфантена й ін., які самі по собі в більшості хороші люди, а багато з них непідкупно-чесні та сповідують простоту, що межує з цинізмом, але, заблукавши на помилкових шляхах, підказаних серцем і почуттями, де не панує вже здоровий глузд (а це найкраща відправна точка!), (...) вони врешті-решт впали в таке сліпе безумство, що, слідуючи своїм безглуздим мріям про благо людства, про благо своїх ближніх, залили людською кров'ю вівтар Батьківщини ... ».

У 1844 році уряд непрямими шляхами (через суперечку 3 приводу виплати заробітної плати) змусив Pesti Hírlap звільнити Кошута [10].

1 березня 1848 р. у м.Братислава, де засідали угорські Державні збори, прийшла звістка про революцію в Парижі. 3 березня в зборах $з$ полум'яною промовою виступив Кошут, який зажадав негайного здійснення ліберальної програми реформ, 
введення Конституції і формування відповідального перед парламентом уряду.

15 березня делегація угорського парламенту відправилася до Відня для передачі петиції, прийнятої на основі програми Кошута. У той же день почалося повстання в Пешті: під впливом опублікованих «Дванадцяти пунктів» Йожефа Іріні та «Національної пісні» Шандора Петефі студенти і міська інтелігенція оточили адміністративні установи міста й змістили муніципальну владу. Вимогами повсталих у Пешті, у першу чергу, стали введення свободи друку, скасування цензури.

Ш. Петефі писав у своєму щоденнику вночі: «Угорська свобода сьогодні народилася, бо сьогодні кайдани впали $з$ преси».

Зразу після перемоги революційних сил розпочався процес створення нових 3МІ. Найбільш було започатковано радикальних газет, хоч їх вплив на населення був незначний. 19 березня виходила газета революційної молоді Marczius Tizenötödike, потім 6 квітня Reform, через чотири дні Die, потім 2 травня Kolozsvári Opposition, a 1 червня - Radical Lap знову в Пешті. Більшість 3 них були недовговічними, наприклад, Köztársasági Lapok, що вперше вийшли 11 жовтня і прожили лише 12 видань, або Jövő, започаткована в грудні 1848 р., проіснувала місяць.

Усі ці видання мали невеликі наклади, так, одна з найбільш значущих газет Marczius Tizenötödike залучила лише 733 підписники. Reform мала 110 абонентів.

У той же час ліберальні газети змогли набрати щонайменше в десять разів більше передплатників, навіть під час занепаду Pesti Hírlap - 2554, близька до уряду Pester Zeitung - 2811, Kossuth Hírlapja - 4214.

Уряд Баттяні створив першу офіційну газету угорською мовою - Közlöny, яка виходила як щоденна газета з 8 червня 1848 року до кінця війни за незалежність. Її редактором був Адольф Гюрман. Він публікував офіційні повідомлення, об’єктивні звіти про суспільно-політичне життя, виступи у парламенті на основі записів стенографістів, створив досить детальний розділ закордонних новин[11].

Був також досить грунтовний розділ закордонних новин. 3 іншого боку, йому разюче не вистачало обгрунтування дій уря- 
ду, пояснення подій чи заходів, а також аналітичної журналістики, що, можливо, було пов'язано з відсутністю консенсусу в самому уряді. Офіційна газета друкувалася у 4500 примірниках.

Кошут також видавав свою газету Kossuth Hírlapjá, яку peдагував Йожеф Байза. 31 червня 1848 року вона виходила як щоденна газета. У часописі працювало близько 50-60 журналістів, більшість яких співпрацювали з Кошутом раніше. Газета детально розповідала про ситуацію в країні, соціальне положення населення, детально повідомлялися новини із закордону. Внизу останньої сторінки були розміщені оголошення. Kossuth Hírlapjá став практично рупором, що підтримував війну за незалежність. На кінець року щодня друкувалося понад 5000 примірників[12].

У 1948 році було випущено багато видів газет. Саме тоді народилися народні газети - Táncsics під редакцією Васа Геребена, вийшло друком майже 3000 примірників, Nép Barátja, яка інформувала про життя провінції, Charivari (Dongó), повідомляла про війну за незалежність.

Після поразки революції імперський уряд видав тимчасовий регламент (липень 1851 р.) щодо регулювання діяльності преси, а у травні 1852 р. був виданий закон про пресу. В цьому документі було визначено дані про тираж, а також регламентувалося право видання книг, умови та спосіб отримання дозволів на публікацію газет і журналів.

Розділ 22 Закону про пресу встановлював принципи та форми покарання. Відповідно до цього розділу, якщо періодичне видання постійно виступає проти імператора, єдності й цілісності імперії, релігії, моралі або фундаментальних основ суспільства взагалі, а його діяльність несумісна з підтримкою громадського спокою та порядку, такому друкованому органу направляється письмове попередження. У подальшому його діяльність може бути призупинена на три місяці розпорядженням губернатора країни, яка входить до імперії. Припинення на більш тривалий період роботи видання або його закриття може бути здійснене лише урядом.

У розділі VIII Закону про пресу було визначено тих, кого можна притягнути до відповідальності за «злочин чи проступ- 
ки, вчинені друкованим органом «. У ньому говориться, що редактори, друкарі та розповсюджувачі, навіть якщо їх вину не вдасться довести, можуть бути покарані за «прояв належної уваги та турботи до змісту публікацій». Тобто, завдяки цій спільній відповідальності Закон ще більше зміцнив практику самоцензури, яка і так була притаманна діяльності преси.

Ефект закону незабаром став очевидним, коли у 1853 році збільшилася кількість нових газет. Розділ 22 було застосовано проти угорської газети місцевою владою лише в одному випадку - в лютому 1858 р. після низки закликів та попереджень про порушення закону.

Історія угорськомовної преси за період десяти років після поразки війни за незалежність доводить, що переможці також мали рахуватися 3 національною культурою та національним духом, які розквітли під час революції. Хоча серед угорців вдалося знайти тих, хто брав участь у імперській антиугорській політиці, вони не змогли створити справжню, цілком надійну та лояльну урядову платформу. I хоч у заголовку Budapesti Hírlap розміщувався двоглавий орел імперії, в самій газеті друкувалися статті представників національної інтелігенції з революційним минулим.

Після поразки революції в Угорщині розпочали видавництво політичних часописів, а саме: Pesti Napló, Magyar Sajtó, a Magyar Hírlap, Budapesti Hírlap, Idők Tanúja. Друкувалися також частково або повністю політичні щотижневики - Politikai Újdonságok, що спочатку було доповненням до Vasárnapi Újság, Magyar Néplap та Magyar Postája[13].

За винятком Коложвара, у провінції виходили щотижневі газети зі статтями та новинами на адміністративні, економічні й соціальні теми місцевого значення. 31857 року Дьор, Арад, Баяа та Сегед випускали власні газети.

У 1850 році було засновано газету Pesti Napló, що стала видатним явищем у масмедіа того часу. Спочатку часопис видавався молодими інтелектуалами, вихідцями з народу, але потім він потрапив до рук журналістів, які представляли консервативну національну опозицію. Під час дворічного керівництва редакцією Яноша Тьорека основна увага приділялася проголо- 
шенню національної єдності, заснованої на матеріальному та інтелектуальному процвітанні. Потім у редакційний період барона Зигмонда Кемені вона стала рупором «пасивного опору», пошуку компромісу на основі політики партії Ференца Деака. Ця національна політика єдності й спільних зусиль об'єднала навколо Pesti Napló однодумців, які зробили цей часопис унікальним явищем в історії угорської преси. Його журналісти правдиво висвітлювали все інтелектуальне життя Угорщини тієї доби. Спочатку газету передплачували 3100 підписників, але $з$ рубежу десятиліття і до середини 1860-х років їх уже було 6000 [14].

Уряд Баха наполягав різними способами на створенні та підтримці офіційної газети угорською мовою. Таким часописом став консервативний Magyar Hírlapot, в заголовку якого був імператорський двоголовий орел, а зміст складався з офіційних новин, в іншому він був схожим на інші політичні газети.

У ці роки угорська преса процвітала та доводила свою життєздатність у всіх видах і сферах масмедіа. Ситуація вітчизняної німецькомовної преси була різною: центральна влада більш-менш підтримувала ці газети, розповсюджувала їх, a чиновники, міські німецькомовні громадяни, читали їх. Але ця преса була провінційною пресою імперії, в якій свою кар'єру розпочали з часом видатні угорські журналісти та письменники. Дві офіційні газети в Угорщині, які видавалися найдовше, - це «Pressburger Zeitung», що виходила у Братиславі, та «Pester Zeitung», започаткована в 1849 році[15].

До середини 1860-х років угорська преса стала важливим політичним чинником у дусі діючих принципів демократії як гарант політичної гласності. Хоча вона діяла лише в межах політичної еліти та соціально привілейованого класу, у вузькому розумінні чи навіть у рудиментарній формі, але за принципами, вже без соціальних обмежень.

Ідея австро-угорського компромісу була прийнята угорською громадськістю, і компроміс був знайдений значною частиною у пресі. Виключним досягненням Ференка Деак, батька Австроугорської угоди 1867 року, було те, що він зміг переконати націю, яка плекала політику в традиціях незалежності й більшість 
якої сприймала політику як опір і повстання, у необхідності компромісу. Створена таким чином політична система проіснувала більше півстоліття. Це було б неможливо без діяльності преси, що була сприйнята громадськістю як авторитетна.

Деак опублікував статтю у великодньому випуску Pesti Napló у 1865 році, де він аргументував необхідність та можливість пошуку компромісу, саме 3 цього він розпочав переговори між Габсбурзьким судом та провідними угорськими політиками.

Після 1867 року уніфікована преса імперії Габсбургів була скасована, а угорська преса отримала свободу.

Державні збори Угорщини зробили зміни у законі про пресу 1852 року, які стосувалися наступного. Присяжні, які контролювали правопорушення в пресі, затверджувалися на королівській або повітовій колегіях. Відтоді Пешт, Косег, Надьсомбат, Дебрецен і Епереш, Ердей, Марошвашархей мали право затверджувати присяжних, що було розумним рішенням з угорської точки зору та з точки зору угорських населених пунктів. У результаті можна стверджувати, що між 1867 та 1875 роками угорська преса мала найвільніший час для своєї діяльності.

Причин для цього було кілька. Розділ 14 Закону про пресу надав серйозний захист громадянському суспільству, це стосувалося як опозиції, так і етнічних меншин. Згідно з цим документом заборонялося переслідувати політичну опозицію.

Цікавим $є$ той факт, що угорський уряд, який прийшов до влади на хвилі боротьби з абсолютизмом, робив спроби обмежити свободу преси. Деякі члени уряду очікували, що преса, як і у часи імперії, буде знаходитися під примусом цензури. Наприклад, Міністр юстиції Болдіжар Хорват хотів зняти депутатську недоторканність із журналістів, які були членами Державних зборів.

Таким чином, після 1867 року уряд так і не зміг здійснити політику утиску преси. За дев'ять років 13 угорських опозиційних газет було притягнуто до кримінальної відповідальності, але 5 були виправдані. Навіть сама кількість обвинувальних актів була дуже низькою, в порівнянні з іншими країнами АвстроУгорської монархії. За один рік у Чехії за правопорушення у 
сфері преси було ув'язнено 18 осіб, тоді як в Угорщині було призначено лише 3 тюремних вироки.

Уряд мав у своєму розпорядженні більше позитивних інструментів контролю над пресою, таких, як дотація газет, придбання певної кількості примірників для державних установ.

На масштаби свободи преси впливало регулювання розповсюдження газет. У часи Міністра внутрішніх справ імперії А.Баха газети можна було продавати лише підпискою. Уже в червні 1867 р. було видано указ, який уповноважував місцеву поліцію дозволити продаж продукції преси на вулиці. Бібліотекарі могли без будь-яких обмежень продавати газети та журнали.

За півтора десятиліття, що пройшли після 1867 року, керівним принципом функціонування преси було слугуванню партійній політиці. Насамперед це стосувалося масмедіа правлячої партії, газети якої: Pesti Napló, A Reform, Jankó Borsszem були високої якості. Ці часописи редагували та писали буржуазні й освічені інтелектуали-журналісти[16].

Після 1867 року Pesti Naplón зазнала серйозних змін, не втрачаючи своєї центральної ролі, відокремилася від прямої партійної політики, ставши незалежною газетою, тим самим посилила свій вплив на читача.

Найважливішими політичними щотижневими газетами правлячої партії були: Magyar Néplap, Hírmondó, Heti Posta.

У 1875 р., коли партія Деака та лівоцентристська партія об'єдналися в Ліберальну партію, на той час Pesti Napló és A Hon були провладними газетами. Однак, справи цих двох видань ішли не дуже добре, кількість примірників неухильно падала. Не отримали вони підтримки і з боку парламентської більшості, оскільки та не вірила у політичні та пропагандистські можливості преси[17].

1 березня 1869 року Лайош Чернатоні запустив нову програму газети малого формату під назвою A Honból és Ellenőr. Ця газета створила нову школу в історії угорської преси: її мета - не служити громадськості, не збільшувати знання та інформування читачів, а свідомо маніпулювати ними $\mathrm{i}, 3$ цією метою, використовувати всі засоби недобросовісного інформування,від 
наклепу до погроз. У влучній редакції Кальмана Міксата, відомого журналіста, депутата Державних зборів, «отруєна зброя почала вкорінюватися в пресі». Майже у всіх опозиційних виданнях з'явилися молоді журналісти, які підтримали цю небезпечну традицію угорської преси[18].

У 1874 р. газету консервативної течії партії Ференца Деака, Közérdek, редагував Імре Галас, один із найвидатніших публіцистів тієї доби. Наступного року, коли Консервативна партія була сформована під час партійних дезінтеграцій та перетворень, вона продовжувала діяти під назвою Kelet Népére. Замість ліберальних доктрин він поставив практичну політику знизу вгору на своєму прапорі. Наприкінці 1878 р. партія об'єдналася в Помірковану опозицію, а з 1879 р. газета видавалася під назвою Magyarország. Часопис жорстоко критикував уряд Тиси за корупцію у сфері державних замовлень, передусім на основі ретельного встановлення фактів та аналітичної журналістської роботи[19].

Імре Галас - висококваліфікований провідний журналіст Угорщини, свого часу також реформував стиль політичної газети. Найважливішим його нововведенням була модернізація редакційної роботи. Редакції угорських газет - не в останню чергу через вплив Кошута на початку 1840 -х років - протягом трьох десятиліть сповідували публікації, що нагадували політичні виступи.

Імре Галас запропонував обговорення серйозних тем проводити тоном, близьким до живого дискурсу, використовуючи різноманітність сюжету, його різнобарвність і доступний стиль.

У цей же період народилися види угорської преси поза політикою. Її журналісти замінили сучасним угорським політичним анекдотом та міськими побутовими жартами. Часопис редагував Адольф Агай протягом майже чотирьох десятиліть, і його першим засновницьким складом були члени Кола любителів кави. Його карикатури малювали відомі того часу художникиграфіки та багато популярних живописців тієї пори. 3 цих постатей виникла розважальна соціографія, насамперед про міські суспільні верстви та представників шляхти. 
Окрім газети Vasárnapi Újság, Magyarország és a Nagy Világ, народилася сімейна газета 3 певним суспільним інтересом. Окрім недільної газети, що стосується угорських протестантських культурних традицій, цей часопис поширює національні ідеї та розглядає суспільство й сім'ю країни як єдине ціле[20].

3 кінця 1850-х років стали видаватися бюлетені та наукові журнали окремих професій. Одним із них був журнал Національної угорської промислової асоціації Anyagi Érdekeink , започаткований з 1879 року, який став одним із найважливіших журналів економічної політики, тиражем 2000.

У 1870-х рр. місцева газета виходила приблизно в третині міських округів: угорськомовна політична преса розвивалася переважно в Східній та Південній Угорщині й Трансільванії, а німецька преса - переважно на саксонських територіях Трансільванії та в містах Західної Угорщини. Угорськомовні газети, що видавалися у вказаних регіонах, набули виняткового значення, оскільки ці частини країни були традиційно орієнтованими на опозицію, а самі опозиційні партії розглядали ці газети як важливий елемент партійної роботи з населенням.

Кількість примірників провінційної преси, яку підтримували партії, становила близько тисячі, а кількість тих, що субсидуються урядом чи адміністрацією регіону, коливалася від 5 до 600. Найважливішими провінційними газетами періоду після 1780 року були: Nagyvárad, Debrecen, Alföld, Magyar Polgár[21]

За три 3 половиною десятиліття 3 1980-х років швидкий економічний розвиток посилив роль промисловості та міст, а добре функціонуюча система державної освіти, заснована на обов'язковій освіті, збільшила кількість людей, які вміють читати. Разом ці умови заклали основу для швидкого розвитку преси та дозволили видавництву газет стати бізнесом. Стрімке зростання угорської преси можна побачити за такими цифрами: у 1870 р. кількість газет, доставлених поштою, становила 15,5 млн, у 1905 р. - понад 154 млн. Згідно з іншим підрахунком, у 1909 році кожна людина, яка вміла читати і писати в Угорщині, отримувала 50 примірників на рік.

Майже півстоліття панування політичної преси партій закінчилося зміцненням незалежної преси, заснованої на інтер- 
есах бізнесу. Зміна була суттєвою. Домінування турботи політичної партії про своє майбутнє та залежність від партійної ідеології утримували газети в екзистенційно вразливому становищі, оскільки їх діяльність, керівництво, склад та зайнятість журналістів визначалися зовнішнім владним аспектом, і ніщо не звільняло газети від їх утручання.

Недобросовісне служіння виключно партійним інтересам, маніпулювання читацькою аудиторією досягли такого ступеня в епоху Іштвана Тиси, Прем’єр-міністра Королівства Угорщини, що поява ділової преси виявилася рятівником суспільної моралі.

Коли кількість газет та преси зростала, коли різні вимоги до преси окреслювалися, різні органи влади прагнули регулювати відносини з пресою у відповідних галузях. Оскільки нападки на журналістів і пресу зростали, виникла необхідність у створенні адвокатських контор, організацій із соціального захисту діяльності газетярів та організацій їх самоосвіти.

У 1880 р. народилася Асоціація журналістів, у 1896 році була заснована Будапештська асоціація журналістів. Пенсійний інститут угорських журналістів був створений у 1881 році. Через десятиліття народився Otthon - об'єднання письменників та журналістів. У 1906 році було створено Національну асоціацію сільських журналістів. За 1903 рік було створено Національну асоціацію католицьких письменників та журналістів, а наступного року Національну асоціацію угорських видавців газет, пізніше - Асоціацію журналістів.

Огляд організацій чітко показує окремі групи інтересів i професій преси, журналістів, газетних видавців та рекламних агентств. Особливий інтерес викликає те, які групи журналістів вважали за потрібне в цей час інституціоналізувати свої окремі інтереси: католицькі журналісти, закордонні кореспонденти та спортивні журналісти й т.ін.

3 часу після 1867 року часто виникало питання про недоліки Закону про пресу, і завжди був впливовий політик чи політична сила, яка вважала, що преса занадто вільна. Наприклад, улітку 1913 року, Іштван Тиса, глава угорського уряду, ледь вступив на цю посаду, заговорив про необхідність регулювання 
преси. Незабаром він виніс відповідний закон парламентським комітетам восени цього ж року для обговорення. Була величезна хвиля протестів, тому що ця пропозиція була зроблена без попередньої професійної консультації, і було дозволено лише дуже вузькі дебати. Але всі ці протести були безрезультатними, 11 квітня 1914 року Державні збори прийняли новий закон (т. XIV.). Сучасники заявили, що це не «закон про пресу», а «закон про націоналізацію преси». Відповідно до закону, систему поліцейської інформації про пресу довелося реорганізувати: поліцейський відділ преси було ліквідовано, було підготовлено спеціальну інструкцію щодо контролю за медіа. У провінції була зроблена спроба повністю заборонити розповсюдження інформації про діяльність поліції та прокуратури. У результаті цих й інших непродуманих кроків ситуація стала настільки загрозливою, що стару систему довелося відновити[22].

Цей закон не проіснував багато часу, щоб суттєво вплинути на угорську пресу. Прем'єр-міністр видав Указ 12.001 / I 1914 року, а саме «Положення про введення цензури під час стану війни». Цим документом вводилися суворі обмеження діяльності масмедіа в Угорщині.

Нижче наводиться таблиця 3 даними про кількість примірників найважливіших угорських газет, які видавалися у період між 1890 та 1910 роками. Тираж надається в тисячах штук.

\begin{tabular}{|l|c|c|c|}
\hline \multicolumn{4}{|c|}{ Табличя 1 } \\
\hline A Nap & $\mathbf{1 8 9 0}$ & $\mathbf{1 9 0 6}$ & $\mathbf{1 9 1 0}$ \\
\hline A Nemzet & & $60-80$ & $80-90$ \\
\hline Alkotmány & 6,2 & & \\
\hline Az Újság & & 8 & 9 \\
\hline Budapest & & 28 & 58 \\
\hline Budapesti Hírlap & 25 & 45 & 45 \\
\hline Budapesti Napló & 28,8 & 54 & 65 \\
\hline Egyetértés & & 22 & 15 \\
\hline Esti Újság & 16 & & 38 \\
\hline Friss Újság & & $70-80$ & $80-100$ \\
\hline Keresztény Magyarország & & $170-180$ & $170-180$ \\
\hline
\end{tabular}




\begin{tabular}{|l|c|c|c|}
\hline Kis Újság & 15 & $170-180$ & $150-180$ \\
\hline Magyar Állam & 6,8 & 15 & \\
\hline Magyarország & & 35 & 46 \\
\hline Neues Pester Journal & 28,5 & 34 & 34 \\
\hline Népszava & $20-22$ & 35 & \\
\hline Pester Lloyd & 15 & 18 & 15 \\
\hline P L. Abendblatt & & 21 & 18 \\
\hline Pesti Hírlap & 26,9 & 54 & 60 \\
\hline Pesti Napló & 8,4 & 32 & 45 \\
\hline Új lap & & $15-20$ & $30-35$ \\
\hline
\end{tabular}

Джерело: Buzinkay Géza. Kis magyar sajtótörténet. https://mek.oszk. $\mathrm{hu} / 03100 / 03157 / 03157 . \mathrm{htm}$

Виникнення угорської журналістики у XVII-XVIII століттях було пов'язане 3 надзвичайно важливими подіями у житті угорського суспільства. Демократична революція 1848 року за незалежність від Австрійської імперії, підписання у 1867 році Австро-угорської угоди, початок війни 1914 року докорінним чином вплинули на створення та подальший розвиток національної преси. На початку XIX століття угорські масмедіа стали відігравати ключову роль у суспільно-політичному житті країни.

\section{Література}

1. Molnár, Miklós: A Coincise History of Hungary. p. 154.

2. Alois H. Pichler: Entstehung der «Pressburger Zeitung», herausgegeben zum 150. Jahrestage, Carl Angermayer, Pozsony-Pressburg 1913.

3. A. L. Schlözer's öffentliches und Privat-Leben, von ihm selbst beschrieben. - Göttingen, 1802.

4. Bokor József (szerk.). Magyar Hirmondó, A Pallas nagy lexikona. Arcanum: FolioNET (1893-1897, 1998.). Hozzáférés ideje: 2011. április 14 .

5. Magyar Musa https://www.arcanum.hu/hu/online-kiadvanyok/ Lexikonok-a-pallas-nagy-lexikona-2/m-1120C/magyar-musa-114D2/6. A magyar sajtó története. Föszerk. Szabolcsi Miklós. Budapest: Akadémiai K. 1979-1985. 
7. Felső-Magyarországi Minerva http://www.kislexikon.hu/felsomagyarorszagi_minerva.html

8. A Jelenkor digitalizált kötetei a REAL-J-ben http://real-j.mtak.hu/ view/journal/Jelenkor.html

9. Kókay György, Buzinkay Géza, Murányi Gábor: A magyar sajtó története. Budapest. Sajtóház kiadó. 2001.

10. Кошут Лайош. https://ru.wikipedia.org/wiki/ Кошут Лайош

11. Közlöny https://mediatortenet.wordpress.com/2014/11/30/ kozlony-1848-1849/

12. Kossuth Hírlapjá https://adtplus.arcanum.hu/hu/collection/ KossuthHirlapja/

13. A magyar sajtó megerősödése https://mek.oszk.hu/04700/04727/ $\mathrm{html} / 322 . \mathrm{html}$

14. Lengyel Géza. Magyar újságmágnások. Budapest: Akadémiai Könyvkiadó, 127. o. (1963) Irodalomtörténeti füzetek 41. szám

15. Alois H. Pichler: Entstehung der «Pressburger Zeitung», herausgegeben zum 150. Jahrestage, Carl Angermayer, Pozsony-Pressburg 1913.

16. A FIATAL LIBERÁLNACIONALIZMUS SAJTÓJA http://mek. oszk.hu/04700/04727/html/436.html

17. Budapest lexikon I. (A-K). Főszerk. Berza László. 2., bőv. kiad. Budapest: Akadémiai. 1993. 23. o.

18. Bokor József (szerk.). Ellenör, A Pallas nagy lexikona. Arcanum: FolioNET (1893-1897, 1998. Hozzáférés ideje: 2010. július 25.

19. Kelet Nép https://books.google.com.ag/books?id=ruV6AAAA MAAJ\&printsec $=$ frontcover $\# \mathrm{v}=$ onepage $\& \mathrm{q} \& \mathrm{f}=$ false

20. I. AZ «ENCIKLOPÉDIAI» LAPTÍPUS KIALAKULÁSA https://mek.oszk.hu/04700/04727/html/476.html

21. Cziráki Zsuzsanna: Az erdélyi szászok története. Erdélyi szász irodalomtörténet. Kozármisleny: Imedias. 2006.

22. 1914. évi XIV. törvénycikka sajtóról https://net.jogtar. hu/ezer-ev-torveny?docid=91400014.TV\&searchUrl=/ezer-evtorvenyei $\% 3$ Fpagenum $\% 3 \mathrm{D} 37$ 


\section{2. Журналістика у період 1918-1945 рр.}

Для того щоб зрозуміти процеси, які проходили у журналістиці Угорщини у період 1918-1945 рр., зробимо невеликий екскурс в історію країни на цьому етапі.

Участь Австро-Угорщини у Першій світовій війні призвела до колапсу економіки і падіння влади Габсбургів. Країни Антанти підтримали об'єднавче стремління слов'янських народів Австро-Угорщини й претензії Румунії на Трансільванію. Нездатність центрального уряду впоратися з відцентровими процесами і стрімким падінням рівня життя, а також неминучість військової поразки призвели до так званої «революції хризантем» у Будапешті, внаслідок чого в листопаді 1918 року Угорщина стала незалежною республікою. При владі опинилися ліберальні сили під керівництвом Міхая Карої, які провели низку демократичних реформ, проте вони серйозно не вплинули на ситуацію в країні в умовах хаосу та триваючого наступу сил Антанти.

20 березня 1919 року представник Антанти в Будапешті Фердинанд Вікс вручив урядові вимогу залишити всі території, на які претендували сусіди Угорщини. Щоб не приймати ці принизливі умови, уряд пішов у відставку, й президент Карої 21 березня передав владу Угорської соціалістичної партії (УСП), що виникла в результаті об'єднання соціал-демократів і комуністів.

УСП проголосила Угорську радянську республіку, сподіваючись на допомогу Радянської Росії в боротьбі з Антантою. Нова влада провела форсовану націоналізацію підприємств, банків, житлового фонду та приступили до соціалістичних перетворень у сфері сільського господарства.

На зовнішньополітичній арені угорської Червоної Армії вдалося зупинити наступ чехословацьких військ і навіть ство- 
рити на нетривалий час Словацьку радянську республіку. Разом 3 тим, через новий виток громадянської війни на території колишньої Російської імперії на допомогу угорській революції не зуміла прийти російська Червона Армія, підтримки якої угорські комуністи надавали вирішального значення.

Одночасно з цим у самій Угорщині стали організовуватися контрреволюційні сили, що користувалися підтримкою Антанти. У результаті союзні держави зробили ставку на колишнього командувача австро-угорським ВМФ адмірала Міклоша Хорті, який зумів створити боєздатні збройні формування, що могли забезпечити наведення порядку в інтересах Антанти. Ці сили вступили в Будапешт після того, як звідти вийшли румунські війська, під натиском яких угорська Червона Армія була змушена відступити із зайнятих позицій, а уряд - бігти з країни.

У 1920 році М. Хорті став регентом Угорщини під час відсутності монарха. Дві спроби останнього імператора АвстроУгорщини Карла IV захопити владу в країні не увінчалися успіхом, і М. Хорті став фактично повноправним керівником держави при збереженні колишнього титулу. В 1920 році також було підписано Тріанонський мирний договір, за яким Угорщина позбавлялася двох третин своєї колишньої території (це були території нинішньої Словаччини, Воєводини, Хорватії, Закарпатської України, історичні області Трансільванія, Банат, Парціум, Марамуреш, Бургенланд). За кордоном проти своєї волі виявилося до третини етнічних угорців.

Надалі усунення наслідків нав'язаного несправедливого миру і відновлення територіальної цілісності стало одним 3 наріжних каменів ідеології консервативного режиму Хорті: будь-які крайні заходи у внутрішній політиці виправдовувалися необхідністю возз'єднання всіх угорців. Другою підставою політичної системи хортизму стала внутрішня консолідація, подолання викликаного подіями недавнього минулого розколу. Спираючись на типові для міжвоєнної Східної і Центральної Європи авторитарні методи, використовуючи при необхідності збройні сили й поліцію, переслідуючи комуністів, режим Хорті зумів домогтися відчутної політичної стабільності. Найбільшим впливом у країні користувалася колишня еліта, включаючи 
землевласницьку, що виключало можливість як би там не було помітної аграрної реформи, вкрай необхідної в умовах земельного голоду, що зачіпало більшість селян.

Зовнішня політика Угорщини в цей період була цілком спрямована на повернення колишніх територій. Угорщина після відомих коливань стала союзницею нацистської Німеччини, яка проводила ревізію принципів Версальсько-Вашингтонської системи міжнародних відносин, складовою частиною якої був Тріанонський мирний договір. У 1938-1940 роках за підсумками двох Віденських арбітражів Угорщина приєднала Південну Словаччину, Закарпаття та Північну Трансільванію, а навесні 1941 року захопила в Югославії область Бачку. Керівництво Угорщини чітко усвідомлювала небезпеку односторонньої орієнтації на Німеччину, однак альтернативи (крім розгрому за польським сценарієм) не існувало.

27 червня 1941 року країна вступила у війну проти СРСР. Після розгрому 2-ї угорської армії в ході радянського контрнаступу на Дону в січні 1943 року розпочалися спроби вийти 3 війни. 3 метою припинення можливих нелояльних дій щодо Третього рейху в березні 1944 року Угорщина була окупована німецькою армією, а при спробі вийти з війни в жовтні того ж року М. Хорті був зміщений з поста і замінений лідером ультраправої організації «Партія схрещених стріл» Ференцом Салаші, що встановив у країні фашистський режим.

У вересні 1944 року Червона Армія вступила на територію Угорщини, повне звільнення якої завершилося 4 квітня 1945 року. Салашісти втратили владу під натиском радянських військ, надавши разом 3 німецькими окупаційними військами запеклий опір, що спричинило за собою колосальну економічну шкоду і великі людські втрати.

3 закінченням Першої світової війни угорська преса потрапила в кардинально нові умови. Угорськомовне населення зменшилося на третину, тобто потенційна читацька аудиторія знизилася саме на таке число. Міста, в яких функціонувала угорська преса, такі як Кложвар, Арад, Темешвар, Нодьварад, Ужгород та Сабатка, опинилися за кордоном Угорщини, потрапили під юрисдикцію іноземних держав. Потрібно зазначити, 
що у попередні десятиліття 3 цих міст вийшло багато талановитих угорських журналістів.

Структура влади і уряду була повністю змінена, все більше революційних хвиль $з$ протилежними ідеологіями слідували одна за одною. Кожний новий уряд вимагав беззастережної підтримки від прес і у той же час вимагав від журналістів відповіді, чому вони працювали на попередніх керманичів. Таким чином, період, коли угорська преса діяла за загальноєвропейськими нормами, закінчився. Від неї вимагали брати участь у політичній боротьбі.

Попередня епоха 3 погляду структури, функціонуючих механізмів та технології преси закінчилася - на авансцену історії вийшли нові 3МІ. 3'явилися способи прискорення зв'язку, телеграф та телефон, друкарські винаходи, необхідні для газетного друку, включаючи фотографію, а також можливості її публікації й різні процеси друку зображень.

Значні зміни відбулися і в журналістській професії, з’явилися спеціальності: редактор, помічник редактора, редакційний публіцист, портфоліо, репортер, кореспондент, редактор новин, графічний художник, графічний редактор. Народилися нові види журналістської стилістики: сенсаційна преса, таблоїдна, бульварна, жовта журналістика. Після Першої світової війни революційні новини доходили до читача незалежно від традиційної преси.

Уже на урочистостях, присвячених тисячоліттю Батьківщини, у 1906 році публіка насолоджувалася документальними кінофільмами, але Перша світова війна зробила кінематограф повноправним учасником медіасередовища. Першу угорську кіностудію було створено в 1924 році, й відтоді їі головним завданням було виробництво Magyar Híradó, угорських новин.

Хоча Тивадару Пушкашу вдалося ознайомити публіку з радіо з 1893 року через свого телефонного кореспондента, стрімкий розвиток цього виду масмедіа відбувся після винаходу у 1901 році Гульєльмо Марконі - італійським вченим і винахідником - «батьком радіо». Спочатку воно застосовувалося у галузі пошти та судноплавства, а потім під час Першої світової війни у військових комунікаціях. Одночасно із заснуванням європейських радіокомпаній у 1924 р. розпочалися регулярні 
угорські радіопрограми. Швидкість радіоновин оцінила угорська публіка під час економічної кризи 1929-31 рр. - це стало загальною потребою під час Другої світової війни, не в останню чергу через можливість отримання західних новин.

Перші телепрограми відбулися ще в 1925 році, майже одночасно в Англії, Америці та Німеччині, а через десять років регулярні трансляції розпочалися в Берліні. Цей засіб масової інформації почав діяти в Будапешті лише в 1954 році.

Після Першої світової війни кіно, радіо та телебачення - новинки світу комунікації зайняли достойне місце в історії преси.

Після закінчення війни уряд Міхая Кароя був змушений підтримувати цензуру в пресі, введену на початку війни, але 7 грудня 1918 р. він видав указ про відновлення свободи преси (Народний акт № 21918 р.) [1].

Цим він скасував воєнну цензуру та запровадив продаж преси на вулиці. На той момент це було не більш, як декларація, аніж крок практичної значущості, оскільки брак паперу не дозволяв створювати нові газети та журнали.

Після того, як 21 березня 1919 року до влади в Угорщині прийшли комуністи, вони прийняли Конституцію Радянської Республіки, стаття 8 якої містила положення щодо свободи преси та ролі преси у суспільстві. У Основному Законі було сказано, що у Радянській Республіці робітники можуть вільно висловлювати свої погляди у письмовій та усній формах, преса, яка слугувала як засіб поширення капіталістичного мислення та затьмарення пролетарської свідомості, перестає функціонувати. Надалі преса не буде залежна від капіталу, і Радянська Республіка забезпечить, щоб соціалістична ідея вільно поширювалася по всій країні [2].

Таке тлумачення свободи преси означало жорстку диктатуру, контроль над пресою та націоналізацію преси, що, до речі, Рада здійснювала $з$ самого початку своєї діяльності. Десятки газет скасовували щотижня, до червня 1919 р. їх ліквідували більше двохсот. Залишилося лише п’ять будапештських та 25 провінційних газет як органи влади на місцях. Літературні, молодіжні й жіночі журнали виживали порівняно краще, але і в цьому випадку здійснювалася жорстка цензура. 
Справами преси займалося Управління преси, яким керував старий соціал-демократичний журналіст Ференц Гондор. Усі функції масмедіа були організовані та регулювалися централізовано, під керівництвом партійних комітетів. Тим часом, наприкінці березня Андор Габор та Міклош Коша отримали доручення розробити правила цензури. 30 квітня роль Управління 3 преси перебрала на себе новостворена Національна рада 3 інтелектуальної власності. Головою іiі був народний уповноважений з питань народної освіти Шандор Шабадош, до складу ради входили Тодор Карман (науковий відділ), Арнольд Хаузер (директор мистецтва) та Лайош Фюлеп, який представляв відділ літератури.

Через тиждень після повалення Угорської Радянської Республіки уряд Іштвана Фрідріха випустив постанову, в якій забороняв усі періодичні видання. Протягом двох років були прийняті декілька нових урядових указів, що регулювали питання преси, включаючи створення Міжвідомчого комітету з питань преси (1920 р.), поки нарешті у грудні 1921 р. прем'єр-міністр Королівства Угорщини Іштван Бетлен не відмінив надзвичайний контроль над пресою. У цій справі особливу роль відіграв угорське телеграфне агентство (УТА). У цьому ж році розпочалася конкуренція між кабінетом прем'єр-міністра та міністерством закордонних справ за керівництво УТА, яке остаточно вирішив Тібор Екхардт, прескерівник урядів міст Арада і Сегеда, на користь кабінету прем'єр-міністра.

Капітан Міклош Козьма, начальник управління пропаганди, розвідки та реагування Генерального штабу Сегеди, був призначений главою УТА. Козьма залишався керувати цим органом до 1941 року, з невеликими перервами. 3 Тібором Екхардтом, який керував відділом преси в Сегеді, було домовлено, що у провінції повинен працювати надійний журналіст з УТА, щоб тільки через нього інформація могла потрапити до вітчизняної та зарубіжної преси. Міністерствам також було доручено направити свої повідомлення в УТА. На початку 1921 р. Уряд приватизував УТА з допомогою Угорського національного економічного банку, заснованого Козьмою, потім підписав з ним контракт, i таким чином УТА стала урядовим офіційним інформаційним 
агентством і навіть медіасилою через інші його підприємства (Magyar Advertiser, Hungary National Corporate, Telefonhírmondó Rt. (Тобто радіо, газета Radio Life, компанія газети Szatmár i Bereg). УТА міг діяти як приватна компанія для іноземних інформаційних компаній та декларував свою незалежність на національному рівні.

У 1920-х роках, під час уряду Бетлена, контроль над пресою повернувся до ліберальної традиції доби дуалізму. Хоча були деякі заборони на газети Újság, Világ, надання державних субсидій, особливо для провінційної преси, відіграло більшу роль. Хоча були тривалі спроби прийняти новий Закон про пресу, що обмежує свободу преси, ці потуги блокувалися Будапештським синдикатом газет, і закон Бетлена залишався незмінним.

Систему підтримки преси продовжив Дюула Гембос, але кошти були сконцентровані в рамках пресвідділу Кабінету прем'єр-міністра на чолі з Іштваном Анталем.

Під час правління уряду Кальмана Дарані у 1938 р. був прийнятий Закон № XV.15 «Про підвищення балансу соціальноекономічного життя», значна частина якого стосувалася регулювання життя преси. У розділі 2 говорилося про те, що потрібно створити преспалату, однією з умов їі діяльності було те, що видавець, редактор та журналісти газет можуть бути членами цього органу. Відповідно до розділу 4 Закону, «євреї можуть бути допущені до складу палати преси, а також палати театрального мистецтва та кінематографії, лише в таких пропорціях, щоб їх кількість не перевищувала двадцяти відсотків від загальної кількості членів цих органів» [3].

Закон про створення медіапалати був виданий Белою Імреді 28 серпня 1938 року, паралельно з цим були опубліковані вказівки щодо його виконання. Трансформацію структури преси офіційно назвали «Зміною охорони», згідно з цим документом медіапалата перейшла під керівництво пресслужби прем'єр-міністра. Її керівником був призначений головний редактор напівофіційної газети Függetlenség Міхай КоложвариБорча. На основі Закону1939 № IV «Про обмеження публічного та економічного простору євреїв» він уже сформував Палату журналістів, у якій кількість євреїв склала лише 6\%[4]. Міхая 
Коложвари-Борча було страчено у 1946 році як військового злочинця.

30 квітня 1939 року Будапештський вісник опублікував список членів Палати. Їх налічувалося 1522 особи - це на триста п'ятдесят менше, ніж відхилених. Палата мала автономний статус, таємним голосуванням обрала свого президента Коложвари-Борча.

Паралельно зі створенням преспалати Міністерство внутрішніх справ переглянуло газетні ліцензії, в результаті чого такі газети, як Est Group (The Est, Hungary, Pesti Napló) були частково скасовані та частково передані уряду, переважна більшість журналістів єврейського походження, особливо з лівими поглядами, не були допущені до преспалати, що означало їх повне виключення з життя преси.

1 вересня 1939 року прем'єр-міністр Пал Телекі оголосив надзвичайний стан, що означало, серед іншого, введення цензури преси та зменшення кількості газет. У той же час він створив окремий офіс 3 контролю за пресою для перевірки іноземної масмедіа. Указом від 10 грудня 1939 р. (10800/1939 ME) він послабив цензуру, тепер редактор мав право вирішувати, чи слід подавати статті до органу цензури, чи ні. Цей захід спровокував напади як нілашистів усередині країни, так і гітлерівської Нiмеччини, хоча угорський уряд обмежував свободу лівої преси.

Постанова уряду від 28 серпня 1940 р. значно розширила цензуру на всі види преси і включила до Комітету з цензури, крім представників прокуратури, Кабінету прем'єр-міністра, міністерств оборони, фінансів, закордонних справ та Генерального штабу. Цензура провінційної преси здійснювалася місцевими прокурорами разом з поліцією.

31941 по 1944 роки, і до німецької окупації, Антал УлленРевіцький був керівником пресслужби прем'єр-міністра та паралельно Міністерства закордонних справ, очолював Комітет 3 контролю за пресою. У політичній ситуації, яка склалася на цей час, концентрація влади у медіасфері дозволила продемонструвати німцям, що їх вимоги до суворої цензури преси виконуються. 3 іншого боку, це було необхідно для того, щоб показати англосаксонським державам, що угорців примусили до таких 
дій. Кожна газета мусила мати так звану книгу замовлень, яку щоденно контролювала цензурна комісія.

Комітет з контролю за пресою відніс друкування деяких тем до виключної компетенції його глави. Наприклад, згідно з приписом на початку 1942 р.; «Цензура дозволяє лише статтю про зовнішню політику, на друк якої дав дозвіл пан Уллен-Ревіцький». Останній особисто перевіряв пресрелізи основних політичних заяв. Однак навіть такі суворі заходи цензури не влаштовували ні німців, ні нілашистів, що безперервно нападали на угорський уряд за надто поблажливий контроль над пресою.

Подальша німецька окупація Угорщини одним махом скасувала подвійність контролю над пресою, і навіть значну частину угорської преси.

А тепер коротко про газети, які виходили у період 1914 1945 років. Офіційною газетою Радянської Республіки була Vörös Újság, під редакцією Кароя Янчо, а потім Ласло Рудаша. Під час окупації румунських військ, які розгромили Радянську Республіку, у Будапешті могла з’являтися лише офіційна Reggeli Újság . Серед старих щоденників - Budapesti Hírlap, Az Est, Friss Újság, Kis Újság, Magyarország, Magyar Újság, Neues Politisches Volksblatt, Neues Pester Journal, Népszava, 8 Órai Újság, Pester Lloyd, Pesti Hírlap, Pesti Napló, Új Lap, Az Újság, Világ és a hetilapok közül a Hétfői Napló, Szabad Szó és a Volkstimme [5].

У 1925 р. у країні було видано 934 газети, з них 618 - у столиці та 316 - у провінції. У 1942 р. уже працювали 1379 газет, 779 - у столиці та 600 - у провінції, що свідчить про потужний прогрес провінційної преси. До 1933 р. Об'єднана партія не мала офіційного друкованого органу, християнська національна ідеологія мала декілька різних напрямів. Католицьку радикальну позицію вперше озвучив проповідник єзуїтів та політик Бела Банга, який з вересня 1919 р. заснував декілька газет, щоб відсунути «руйнівну єврейську пресу» на другий план. Új Nemzedék (1919-44), Nemzeti Újság (1919-44), Új Lap (1919-44), Gondolat - літературно-політичний журнал та Képes Krónika журнал 3 малюнками[6].

У 1933 році для підтримки цих видань була заснована компанія «Центральна преса». Це потребувало регулярної фінансо- 
вої підтримки преси з боку уряду, у 1930-х - понад двісті тисяч пеньго на рік, - хоча Új Nemzedék, було рентабельне, бо виходило у 77000 примірниках та стало однією з найвидатніших сторінок доби.

У 30-х роках католицька преса мала суперечки з офіційною політикою у все більшій кількості областей: спочатку з питань німецької орієнтації, а потім з питання арійської раси, першість якої вона не визнавала. 3 часу введення в дію єврейських законів вони відкрито відступали від концепції уряду, вважаючи, що ці законодавчі акти занадто лояльні до євреїв - хоча підтримка інших принципів внутрішньої політики уряду залишалася незмінною. Єпископське керівництво очікувало, що католицька преса буде триматися подалі від екстремізму, але це також включало утримання від відкритої критики окремих церковних осіб. Це застереження кілька разів стосувалося журналу генерального директора компанії «Центральна преса» графа Дьорджі Сечені, Korunk Szavára. Заснований у 1931 році, цей часопис поєднав ідеї легітимності, демократичних прагнень, християнського лібералізму та невпинного антинацизму.

Szózat (1919-26 та 1940-44, у 1926-31 виходив під назвою Magyar Újság) був започаткований з метою підтримки контрреволюційних урядів. Його розпочав Ференц Улейн, один $з$ лідерів асоціації «Південний», а його першим головним редактором перейшов Ендре Байчі-Желінський. Газета від 1923 року відійшла від підтримки уряду, щоб підтримати праву опозицію.

У двадцяті роки декілька угорських газет стали сповідувати расистську ідеологію (Nemzeti Élet, Vitézek Lapja, Nemzeti Figyelő, Pesti Újság), до них приєдналася й аграрна газета. Всі ці часописи не мали великого впливу на читацьку аудиторію, одна лиш Pesti Újság, яка видавалася під редакцією Золтана Мешко. щотижня (1929-42) була більш помітним явищем у пресі того часу. Расистська та католицька преса виступили одна проти одної на початку 1920-х років, після того, як расисти звинуватили католицьку пресу в зраді справи, центральні угорські газети успішно врівноважили вплив расистської преси[7].

Magyarság (1920-44) - часопис, що фінансувався графом Дюлою Андраші, був заснований Іштваном Мілотаєм та 
Шандором Петьо для створення національної єдності правого кшталту. Інколи газета служила расистам реформаторського кольору, в інший час вона була принциповим католиком, який відстоював національні інтереси (наприклад, коли нападав на так званих ліберальних представників реформаторської церкви), а також налетів на графа Куно Клебельшберга, як надмірного ліберала.

Прихід до влади в Німеччині Гітлера також спричинило кризу цієї газети. Петьо відкрито висловив своє побоювання 3 приводу того, що німецькі нацисти прагнуть до експансії. 3 іншого боку, Іштван Мілотай журналіст $з$ праворадикальними поглядами, разом з декількома колегами навесні 1934 р. на прохання Дюли Гомбоша (прем'єр-міністра Угорщини) заснував явно прихильну до нацистів проурядову газету Új Magyarságot. 31938 р. перетворилася у рупор праворадикальної ідеології. У цей час Угорщина пішла за нацистським та антирадянським напрямком, у той же час прагнучи узгодити легітимізм та лібералізм. На початку 1938 року було оголошено, що Magyarság стає щоденною газетою націонал-соціалістичного руху, і ії головним редактором став Калман Хубай, один із лідерів нілашистів, Шандор Петьє та кілька журналістів, які виступали проти руху нілашистів, вийшли з редакції [8].

Прихід до влади Дюли Гомбоша також збільшив кількість та вплив захисників расизму всередині уряду. За часів прем'єрміністра Королівства Угорщини Іштвана Бетлена (1921-1931pp.) Budapesti Hírlapés та 8 Órai Újság були газетами, близькими до уряду, але в 1933 році новий керівник пресслужби Іштван Антал встановив напівофіційну Függetlenséget (1933-44) з постійною субсидією для рішучого впливу на середній клас у провінції. Калман Хубай став його редактором, а газета видавалася зусиллями в основному молодих журналістів, які приїжджали 3 провінції. Соціальна демагогія газети знайшла резонанс у цільової аудиторії, вона сягнула 70000 примірників за один рік. Його незалежною парою була Esti Újság (1936-44), яку також редагував Хубай [9].

Після анексії Німеччини й Австрії Хорті та його уряд одноголосно прагнули послабити залежність від фашистів та посла- 
бити крайню праву орієнтацію урядової преси. Калман Хубай був знятий з посади в обох газетах. I хоч головний редактор Esti Újság Тибореш Янош Маккая змінив звучання газети у потрібному напрямку, Міхалій Колошвари-Борча став новим редактоpoм Függetlenség[10].

У середині 30-х років було випущено низку газет, які сповідували нілашистську ідеологію. Газета Золтана Мешко, Szava Szava (1932) спершу стала прихильником націонал-соціалістичної ідеї, потім різні фракції нілашистів започаткували свої газети (Kitartás, Magyar Szocializmus, Nyilaskereszt, Összetartás, Szittyakürt, Virradat, Egyedül Vagyunk stb.). Найважливішою з них була Pesti Újság (1939-42). Багато молодіжних тижневиків і журналів хотіли відігравати певну роль у національній освіті молоді: з католицького боку (Zászlónk, Emericana, Ébresztő, Az Erő), з протестантського боку (Református Diákmozgalom). 3 державною підтримкою друкувалися Levente, Ludovikás Levente. Хоча Дежо Сабо був однією 3 найвпливовіших провідних фігур расової ідеології, близько 1923 р. він заснував журнал Élet és Irodalom. Журнал нападав як на уряд, так і на расистів [11].

Під редакцією Тормай Сесіля у 1922 році був започаткований часопис Napkelet для християнської та національної генерації письменників і був створений для противаги Заходу. Хоча його авторами були престижні письменники та вчені, він не зміг досягти значної кількості примірників. Журнал Magyar Szemle (1927-44) за редакцією Дюли Секфю, за підтримки Іштвана Бетлена набув ще більшого значення. Пізніше його головним редактором став Шандор Екхардт. Hungarian Quarterly та Nouvelle Revue de Hongrie надавали докладну інформацію про Угорщину за кордоном. Після березня 1944 року вони були заборонені [12].

Що стосується ліберальних газет, то їх підтримували банки й велика промисловість, таку підтримку інші отримували від партій або у вигляді державних субсидій. GYOSZ (Національна асоціація промисловців) та TÉBE (Асоціація ощадних банків і банків) зберегли ту пресу, яка їх підтримувала, вони отримували вигоду від реклами, у тому числі платну, та постійні публікації в економічній колонці газет. У 1930-ті роки політика 
підтримки GYOSZ-TÉBE змінилася; коли раніше газети групи Est-konszern були на першому місці, тепер на перший план вийшли антинімецькі: Magyar Nemzet, a 8 Órai Újság, Az Újság. Підтримку отримали також католицькі газети.

Серед ліберальної політичної преси та таблоїдів видатну роль відіграв літературний керівник газет Est Лайош Мікеш, особливо в якості культурного оглядача газети Pesti Napló. Világ послідовно залишався радикальним буржуазним часописом, який виступав з різкою критикою уряду. Нарешті, у 1926 році, через його статті про політичний контекст справи про друкування фальшивих франків в Угорщині (відома справа підробки франків в Угорщині в 1925 році), уряд заборонив газету, незважаючи на те, що звинувачення у «національній образі» було визнано судом необгрунтованим.

У той час редактор Геза Фелекі та співробітники його редакції придбали Magyar Hírlapot, але вони не змогли дати йому ладу. У 30-ті роки більшість ліберальних газет були обов'язково радикалізовані внаслідок ідеологічного тиску на них. Дьордь Балінт у 1929 р. активно публікується у Pesti Naplóban. У другій половині 1930-х років, особливо після утворення палати преси, уряд остаточно скасував ліберальні 3МI, які, вдруге з часу медіаполітики Іштвана Тиси - прем’єр-міністра Угорщини, насаджували у пресі політичну нетерпимість та авторитаризм [13].

25 серпня 1938 р. Шандор Петьо випустив свою нову газету Magyar Nemzetet, яка відстоювала єдність угорської нації. Гасло газети звучало так: «Угорська нація бореться за те, щоб Угорщина була угорською країною». Він розпочав 3 видання двадцяти тисяч примірників на день, а у 1942 році вийшов друком у п'ятдесят тисяч екземплярів. Часопис став прибутковим як господарське підприємство, та завдяки своїй популярності він зміг ще більше збільшити кількість примірників: у 1943 році його тираж збільшився до 60000 примірників на день.

Szellemi honvédelem, що виходила в недільних випусках i під редакцією Золтана Сабо, мала персональний образ та була дуже ефективна за змістом. Шандору Петьо довелося піти з цієї посади, тоді Дюла Хегед зайняв посаду редактора на три роки. Szellemi honvédelem відрізнялася послідовною і сміливою по- 
зицією, тому іï кілька разів закривали, після вторгнення в Угорщину Німеччини іiі заборонили[14].

У кінці двадцятих років 3'явилося об'єднання народних письменників. Їх інтелектуальною базою та зразком для наслідування була творчість Ендре Байчі-Жілінського та Дежо Сабо. Байчі-Жілінський започаткував щотижневик Előörs (1928-32), а потім, як продовження, Szabadságot (1932-44), в якому опубліковано, крім інших, цілу низку представників провінційної літератури, а саме: Геза Фея, Дюла Іллієш, Янош Кодолані, Імре Ковач. Народні письменники створили Válasz (1934-38), тепер також за участю Ласло Немета, а в 1939 році вони придбали Szabad Szó - щотижневик, який розпочав редагувати Пал Сабо. У ньому публікувалися народні письменники, що звертаються до ідей народовладдя, тоді як ті, що стояли на крайніх правих поглядах, публікувалися в Új Magyarság. Невідома форма журналу, яка з'явилася раніше, яку писав і видавав лише редактор, отримала розповсюдження серед народних письменників. Такими були журнали Сабо Дежьо, Тапú Ласло Немета (1932-36), журнали Ердеі Йожефа та Нодь Лайоша [15].

3 літературних журналів Nyugat залишався журналом найвищого рівня та найвищого літературного зразка. У двадцятих роках його редактором був Ерн Осват, після його смерті його перейняли Міхай Бабіч і Зсігмонд Моріч з метою об'єднання «розділеної літератури». У 1929 році було започатковано тижневик Toll, який півроку редагував Бела Жолт. Цей радикально налаштований реформаторський часопис характеризувався вимогливим змістом, дуже широким різноманіттям журналістів та надзвичайно малою кількістю примірників. Він проіснував до 1938 року [16].

Наступним літературним журналом був Literatura, який започатковано у 1926 році. Це був ліберально-літературний та критичний журнал. Високоякісними журналами для творчої інтелігенції в ті часи були: Független Szemle (редактор Жако Амбpo), Századunk (редактор Вамбері Рустем), Szép Szó(редактори Йожеф Аттіла, Ігнотуч Пал, Фей то Ференц). Дві дуже успішні газети для широкої громадськості були Tolnai Világlapja та Színházi Élet (ред. Шандор Інце) [17]. 
Флагманом соціал-демократичної преси продовжувала залишатися газета Népszava. Вона пережила весь міжвоєнний період, хоча було два роки, коли проти неї було порушено 347 позовів у судах. Її тривалий час редагував Іллієш Монуш, з 1939 р. Арпад Сакаіч.

Після Першої світової війни у державах, які отримали згідно 3 Тріанонською мирною угодою угорські території, розвинулося значне активне життя угорської преси. У Чехословаччині видавалася Prágai Magyar Hírlap, була газетою опозиційних угорських партій. Її почали друкувати в Ершекуйварі, потім у Комаромі та, нарешті, у Братиславі. У 1922 році з'явилася провладна газета Reggel, яка була трансформована у Magyar Világ. Kassai Munkás (1907-37) був спочатку часописом соціал-демократів, а потім комуністів. Католицькі молодіжні журнали Mi Lapunk. Új Szó (1929, 1932-33) були літературними часописами, що симпатизували соціал-демократичним та комуністичним ідеям. А Magyar Írás (1932-37) друкував твори великих угорських письменників, це був ліберально-літературний та критичний журнал [18].

У Югославії було видано значну кількість угорських газет і журналів. Найважливіші з них: «Bácsmegyei Napló», що виходила 31932 року в Суботиці; газета Újvidéki Reggeli Újság, Kalangya - літературний журнал, який видався більше десяти років та мав епохальне значення в угорській літературі в Югославіï; Híd (1934-41) відіграв важливу роль у міжкультурному діалозі.

Було також багато переважно короткотривалих угорських газет у Трансільванії. Румунія зібрала в собі найрізноманітніші напрямки преси. Brassói Lapok розпочалася як додаток до коложварської Keleti Újság у Клуж-Напоці, й там з'явилася Ellenzék, заснована Міклошом Бартою (1919-40), як Erdélyi Szemleutódjaként, Жігмонд Ременік започаткував Pásztortüzet Napkelet (1921-44), трансільванський журнал, який видавався найдовший час. Особливим був короткотривалий часопис Дьорджі Санто Periszkóp, який мав на меті представити угорськомовній публіці західноєвропейський літературний авангард. Дитячий часопис Cimbora, який видавав Бенедек Елек 3 1922 року, став популярним журналом з високим тиражем[19]. 
У 1926 р. Барон Янош Кемені запросив у замок Маросвець 26 угорських письменників, щоб узгодити всі їх суперечності та об'єднати їх в інтересах угорської культури. Журнал Erdélyi Helikon виріс із цієї визначної ініціативи (1928-45).

Трансільванські молоді письменники започаткували журнал Erdélyi Fiatalo - це часопис із широким світоглядом та соціалістичною орієнтацією, який редагував Ласло Дієнеш, а потім з 1926 року Габор Гала протягом трьох років. Мав своїх журналістів в Угорщині, Югославії та Чехословаччині. Мав тираж у 1000-1200 примірників.

Наймолодші письменники видавали свій журнал Termés у Коложварі (1942-44).

Комуністична еміграція спочатку видавала щоденну газету під назвою Magyar Újság (1920-24), а в Москві видавалася газета Szó, щоб агітувати полонених угорців. 3 вересня 1944 p. Радянська армія також видавала газету під назвою Magyar Újság, наступником якої стало Új Szó [20].

19 березня 1944 р. Німеччина окупувала Угорщину. Через три дні ліберальна, незалежна та ліва преса були заборонені. Двом німецьким чиновникам та партійним функціонерам, які приїхали сюди, було доручено переробити угорську пресу на нацистський німецький зразок. Постанова Уряду від 6 квітня 1944 р. уповноважувала прем'єр-міністра призупинити або припинити діяльність будь-якої газети чи журналу в інтересах суспільства.

Державним секретарем 3 питань інформації став Міхай Колошвари-Борча, а після захоплення влади Салаші, головним редактором Összetartás, став Ференц Фіала, представник нілашистів. Незабаром у первісному вигляді з'явилися лише дві газети нілашистів, але до облоги Будапешта радянськими військами залишилися лише тижні.

Під час тривалої облоги Будапешта не з'явився інший медіапродукт, окрім листівок. Життя преси вже почалося в східних частинах країни, і перші газети почали з'являтися: Néplap, в Ceгеді в 15 листопада 1944 року. На наступний день після визволення Пешта від німецької окупації в столиці, 19 січня 1945 р., була започаткована газета Szabadság, яка видавалася щоденно, 
редакторами були Йодеф Дарвас, Дюла Калаі та Лайош Зілані звичайно, цей часопис контролювали комуністи. Комуністичні журналісти газети вперше зіткнулися з радянською цензурою, коли вони хотіли виступити проти жорстокостей окупаційних російських військових. Ерньо Геро - один із керівників комуністичної партії, був категорично проти найменшої критики в бік Червоної армії. У перші дні стало зрозуміло, що свобода преси, принаймні, що стосується Радянської армії, не працює[21].

А тепер повернемося до ще однієї цікавої сторінки в історії масмедіа міжвоєнного періоду Угорщини, а саме створення та функціонування радіо.

У 1925 році в Угорщині було прийнято Закон про радіо, який мав видатне значення для розвитку правового середовища радіомовлення. Перша справді сучасна радіорегламентація Угорщини, відповідаючи на всі важливі регуляторні питання епохи, народилася за європейськими стандартами. 1 грудня того ж року угорське «мовлення» вперше випустило свою програму. Ця епохальна подія вимагала дійсно гарного правового регулювання. Це було реалізовано Указом К. М. 32.250 / 1925 р. (XI. 10.). 1925 р. Про державний бюджет 1925 р.: IX. тс. Стаття 24 (2). Цей документ уповноважує міністра комерції всебічно регулювати радіоемісію (включаючи виробництво, розповсюдження, володіння, передачу обладнання та пристроїв і встановлення певних кримінальних положень). Однак цей документ був унікальним тим, що надавав міністру такі повноваження, що, всупереч принципу законодавчої ієрархії, він міг приймати нормативні акти у цій царині. Саме у світлі цього мандату народився новий «Указ про радіо», який навіть порівняно з низкою іноземних зразків був значно прогресивнішим.

Перше сучасне законодавство Угорщини, що регулює повсякденне життя електронної преси, значною мірою спиралося на регламенти регулювання попередніх років. Воно зберігало всі достоїнства, набуті за роки діяльності радіо, та виправляло недоліки необхідними детальними правилами.

У радіотехнічному праві державна ексклюзивність випливає з існуючого реєстру телеграфного закону, оскільки радіо задумувалося як тип телеграфа. 
Забезпечення виключного права держави у цій сфері включало пріоритет виконання завдань державного управління, охорону громадської безпеки, забезпечення громадського порядку та безпечну доставку «надзвичайно» важливих і конфіденційних комунікацій. Важливість ролі держави посилювалася також аргументом того, що головна мета - не заробляти прибуток, а надавати якісну послугу. За характером застереженого права випливає, що відносини між державою та ліцензіатом не були приватноправовим договором, а публічно-правові відносини встановлювалися на основі ліцензії, заснованої на публічному акті. Надання ліцензії регулювалося на розсуд Міністра, ця широка влада лише підсилювалася правилом про те, що при здійсненні свого рішення відмова чи анулювання ліцензії або будь-яка інша супутня вигода, а також інші обмеження, жодна претензія не може бути подана, поки держава виконує вищезазначені положення.

Початок регулювання електронної преси в Угорщині. Указом було сформульовано спеціальні правила для операторів радіопередавачів, тобто для «мовників». Важливим елементом теми $\epsilon$ те, що законодавство розмежовувало т. зв. радіомовну станцію для загальнодоступного користування, тобто «радіопередавач» від служб, інституціоналізованих не для громадського використання, та для певних спеціальних (суспільних інтересів) цілей та потреб. У той час, як покликання «радіомовного» передавача $є$ так званим радіомовленням для всіх, хто уповноважений встановлювати та керувати приймальним обладнанням, їх можна зрозуміти (наприклад, це власне радіомовлення), тоді як специфіка різних типів мовників полягає лише в тому, що його діяльність може бути дозволена лише обмежувальним шляхом для конкретних суспільних інтересів чи інших благородних цілей.

Недержавні передавачі та пов'язані з ними радіоприймачі можуть також експлуатуватися в приватних цілях, для приватного користування, з відповідним дозволом, з обмеженням, що установка і підтримується для таких цілей, що може мати лише металопровідну інфраструктуру. Два типи передавачів також показують різницю в дозволі їх встановлення. Право на вста- 
новлення «податку на мовлення», оскільки, як уже згадувалося, вважалося державним монополістом, належало виключно до La Poste, i якщо Поштове відділення, яке представляє органи державної влади, не запустило таку послугу, не створило станцію або призупинило іiі роботу з будь-якої причини, ліцензіати приймальних пунктів не мали права на відшкодування збитків. Однак держава може передати свої зарезервовані права на мовлення у формі ліцензії, квазі-орендуючи їх. Такі договірні відносини можна розглядати як особливі приватно-правові оренди, що не грунтуються на приватній автономії сторін, а як публічно-правові оренди публічного характеру, що впливають на державне верховенство.

Перші широкомовні передачі почалися в Угорщині навесні 1924 року з Наукового інституту Королівської пошти. Під керівництвом технічного директора Бернарда Пашко кілька радіоаматорів з числа працівників інституту зібрали передавач потужністю 250 Вт. Увесь інвентар студії, що розташовувалася на горищі, складався зі столика з саморобним мікрофоном і піаніно. Природно, через малу потужність передавача більш-менш стійкий прийом був тільки в декількох районах Будапешта. Проте досвід визнали вдалим, і Королівська пошта вирішила створити Національне радіо. Перша програма вийшла в ефір 1 грудня 1925 року через студію на вулиці Ракоці, потужність передавача «Телефункен» склала 2 кВт, що забезпечувало досить стійкий прийом в Будапешті й ближніх околицях. На момент початку мовлення було 17072 абонентів, рік по тому їх число зросло до 56383 осіб. 1920-ті роки не дарма назвали героїчною добою в історії радіомовлення. Передачі велися виключно в прямий ефір, тому були неминучі різного роду накладки.

Незабаром після початку регулярного мовлення Національне радіо вирішило застосувати новинку - зачитувати новин на два голоси: чоловічий і жіночий. Диктори-чоловіки вже були в наявності, а для жіночого голосу найняли актрису одного будапештського театру.

У 1927 році Національне радіо отримало новий передавач «Телефункен» потужністю 3 кВт і перебралося в новий Будинок радіо на вулиці Шандор. Однак і тепер хороший прийом 
був не далі 50 км від Будапешта, тому на високому пагорбі в Лакхеде (на околиці Будапешта) почалося будівництво нового передавального центру. 29 квітня 1928 р. передавач потужністю 20 кВт почав роботу, для розміщення антен звели металеву 150 м радіощоглу. На жаль, і новому передавачеві не вистачало потужності, тому вже через рік у Лакхеде почалися монтажні роботи. Нову радіостанцію, побудовану за останнім словом техніки, урочисто відкрили в грудні 1933 року. Висота підйому антени становила 314 м, а потужність передавача 120 кВт, і нова радіостанція, яка отримала назву «Будапешт I» не мала рівних у світі. 20 кВт передавач також залишився в роботі. Він отримав назву «Будапешт II» і вів мовлення на столицю. Нарешті програми національного радіо можна було приймати на всій території країни і число радіопередплатників Королівської пошти перевищило 300 тис. осіб. Однак був нюанс, майже дві третини слухачів мали детекторні приймачі й проживали в столиці або столичних передмістях. На решті території Угорщини сигнал «Будапешта I», як і раніше, був занадто слабкий для доступних детекторних апаратів, а чотири слабких ретранслятори в провінційних містах стану не покращували. Прийом національного радіо був можливий тільки на лампові приймачі, яких у провінції налічувалося менше 50 тис. штук. Проте, на тисячу жителів в Угорщині доводилося вже 43 радіоприймачі, в той час, як у Польщі - 25, в Румунії - 12, в Югославії - 11 і в Болгарії - 3 .

Загалом Радіо Угорщини йшло в ногу з часом: новини; концерти сучасної, класичної та національної музики, в тому числі за заявками слухачів; трансляція опер з Королівського театру, щоденні «Жіночі поради» $з$ відповідями на листи слухачок, діти слухали розповіді й казки Дядечка Оскара і Дядечка Бергенгоца.

Уже з грудня 1925 року щонеділі передавали католицьку заутреню, а дещо пізніше почалася трансляція служб і головних протестантських сповідань Угорщини: кальвіністів, унітаріан та лютеран. Корінні відмінності в догматах не завадили церквам без суперечок домовитися про «свої недільні» ефіри. Прикметно, що на відміну від керівників Радіо Угорщини, отці церкви відразу усвідомили, які величезні можливості радіо у 
сфері пропаганди, так і необхідність докорінної зміни формату для пристосування служб та проповідей до радіомовлення. Урочисті й вивірені до дрібниць недільні служби ніяк не піддавалися скороченню заради сітки мовлення. Залишалися проповіді, однак і до них потрібно підійти по-новому. Образно кажучи, якщо в церкві священник проповідь виголошував, то з радіослухачами він розмовляв за допомогою приймача.

Творчі пошуки увінчалися повним успіхом. У 1936 році вийшла збірка католицьких радіопроповідей під традиційною угорською назвою «Неопалима купина», яка протягом декількох років витримала кілька видань. Кальвіністський збірник радіопроповіді називався так само традиційно - «батіг, що бичує» - і також користувався не меншою популярністю.

Проте поступальний розвиток національного радіо було порушено покладеним на нього в 1933 році обов'язком «боротися і захищати національну культуру», помітне місце в якій займала музика. Поставлену задачу радіо стало вирішувати «в лоб» - більшу частину сітки мовлення відвели під народну музику, причому час щоденного мовлення значно скоротився. Беручи ці досить дивні на нинішній погляд рішення, керівництво радіо виходило з власних уявлень про слухачів, їх переваги і смаки.

На перший погляд, національний ефір надійно захищав мовний бар'єр. Однак переважна більшість дорослого населення Угорщини володіло німецькою мовою - державною мовою, яка канула в Лету двоєдиної монархії, і командною мовою цісарсько-королівської армії. Вельми численними були національні та релігійні меншини, для яких німецька і зовсім була рідною. Тільки дунайських швабів в Угорщині було понад пів мільйона. Першою недобре запідозрила Королівська пошта, в якій різко впало число нових передплатників на радіо. У відповідь посилили боротьбу з радіозайцями, ввівши поквартирні та побудинкові обходи з наклейкою на радіоприймачі контрольних марок абонентської оплати. I слухачі почали «голосувати налаштуванням радіоприймачів». Німецьке або австрійське радіо ловили заради гарної сучасної і класичної музики, в тому числі й угорських композиторів. Люди вільних професій налаштовувалися на ВВС або Радіо Франції. У великих кількостях ви- 
никли «радіокафе» і «радіокорчми», куди після роботи дружно йшли прості люди. Там їх чекали потужні радіоприймачі з хорошими антенами, і відвідувачі влаштовували вечори прослуховування далеких країн. Загалом, як сухо відзначала таємна поліція: «радіоприймачі й радіопередплата купуються тепер виключно для легального прослуховування закордонних станцій». На той час в Угорщині склалася потужна радіопромисловість, що спеціалізувалася на випуску висококласної апаратури. «Велика четвірка» радіозаводів складалася з фірм «Оріон», «Філіпс», «Стандард» і «Телефункен». Флагманом був завод «Оріон», що належав національному капіталу, на його частку припадало більше половини річного випуску приймачів. При цьому всі технологічні ланцюжки замикалися на угорських виробників комплектуючих, причому національна промисловість самостійно освоїла розробку і виготовлення радіоламп. Командні висоти займала фірма «Тунгсрам», згідно з картельною угодою іiі частка на європейському ринку радіоламп становила 12\%. Фірма належала угорському капіталу і вела активну експансію за кордон, побудувавши, наприклад, радіоламповий завод у Голландії.

У другій половині 1930-х років річний випуск радіоприймачів Угорщини становив понад 100 тис. апаратів, однак низький платоспроможний попит усередині країни змушував виробників орієнтуватися на зовнішні ринки. Понад три чверті приймачів експортувалися в десятки країн, причому угорські фірми займали міцні позиції навіть на найбільшому в Свропі, дуже вимогливому і високо конкурентному, німецькому ринку. Прикметно, що випуск радіоприймачів тривав аж до німецької окупації Угорщини в жовтні 1944 року. Постачання приймачів і радіоламп за кордон організували через Іспанію й Туреччину, $\mathrm{i}$ вони були найважливішим джерел валютних надходжень.

Поворот на краще стався лише в 1938 році, коли на прикладі сусідньої Австрії угорські правлячі кола переконалися, наскільки потужним знаряддям є радіопропаганда. Щоденна сітка мовлення була повністю змінена і іï привели у відповідність до сучасного на той час німецького рівня. До того ж програми державного радіо стали розглядатися як спрямовані й на закор- 
донних угорців. Тому в тому ж році почав регулярну роботу короткохвильовий передавач, який мовив угорською на Балкани.

Одночасно з удосконаленням мовлення потрібно вирішити проблему з доступом населення до самих радіопрограм. На перший погляд, можна було скористатися вдалим досвідом Італії та Німеччини щодо програми «народного радіо», однак і німецькі, й італійські «народні приймачі» продавалися за ціною значно нижчою собівартості, а різниця покривалася державою. За польським прикладом можна було налагодити масовий випуск дешевих детекторних приймачів. Але для цього потрібна густа мережа досить потужних радіопередавачів, на створення й експлуатацію якої у Королівської пошти не було коштів. Ефективним рішенням був би розвиток дротового мовлення, тим більше товариство «Телефон Хіромондо», включене на початку 1920-х років до складу Радіо Угорщини, напрацювало величезний технічний досвід у цій царині . Разом з тим, технічні обмеження не забезпечували гучномовну передачу, а створення відокремленої мережі дротового мовлення також вимагало значних коштів. Використання для дротового мовлення телефонних ліній, за прикладом німецького драхтфунка, не мало сенсу, власники міських телефонів уже мали приймачі.

Розробку народного приймача здійснила фірма «Оріон». Ціну продажу встановили в розмірі 43 пенге (48 пенге в розстрочку на два роки) при собівартості 30 пенге. Крім того, річна абонентська плата знижувалася до 1 пенге. Проте за іншими даними собівартість приймачів становила 57,3 пенге, тому різницю, що утворилася, спільно брали на себе радіозавод і електромережеві компанії. Конструкція повторювала німецький прототип, однак для подальшого здешевлення був виключений діапазон довгих хвиль (тим більше, радіо Угорщини мовило тільки на середніх хвилях) і роз'єми для підключення додаткових пристроїв-шпаркрейсів. Дволамповий радіоприймач виконувався за схемою прямого посилення, для підвищення чутливості й вибірковості прийому в схему було введено так званий «зворотний зв'язок». 3 хорошою антеною приймач забезпечував прийом більшої частини європейських радіостанцій. Народні приймачі випускалися в двох варіантах: тільки 3 мережевим 
живленням (чотири різних напруги) і з додатковим батарейним. На відміну від підкреслено суворого дизайну німецького прототипу, футляр народних приймачів був виконаний у так званому національному стилі.

Про початок програми народного радіо було оголошено 19 квітня 1939 року, коли Королівське міністерство торгівлі, Королівська пошта і найбільші радіозаводи країни - «Оріон», «Філіпс», «Стандард» і «Телефункен» - уклали угоду про виготовлення і збут до кінця року 20 тисяч радіоприймачів стандартизованої конструкції. Радіоприймачі першого замовлення розпродали вже за кілька тижнів, а 31 січня 1940 року в продаж надійшло друге замовлення 325 тисяч штук. Усього ж до німецької окупації виготовили близько 130 тисяч народних приймачів.

Однак, незважаючи на вжиті заходи, кількість радіоприймачів у країні росла повільно. Якщо в 1935 році їх налічувалося 352902 шт., то в 1940 році - 499368 шт. Однак сталося якісне оновлення парку, число детекторних приймачів зменшилося майже втричі й склало 66638 шт.

Друга світова війна найдраматичнішим чином позначилася на Радіо Угорщини: в листопаді 1944 року німці підірвали щогли радіостанції в Лакіхеде і знищили унікальний передавач, а Будинок радіо сильно постраждав під час вуличних боїв у Будапешті. Починати довелося 3 самого початку, вцілів лише найперший 2 кВт передавач, 3 якого почалося регулярне мовлення. Його вивели з роботи ще в 1928 році, й він пережив війну, зберігаючись у розібраному вигляді на складі. Старий передавач швидко зібрали, і за допомогою радянських фахівців Радіо Угорщини відновило мовлення вже 6 червня 1945 року. Сучасний вигляд Угорське радіо набуло після націоналізації в 1949 році, коли були створені радіостанції «Кошут»- державне радіо, і молодіжна радіостанція «Петефі» (згодом до них додалося - передає класику - радіо «Барток» і радіо «Данко» - передає легку музику). Однак проблема забезпечення доступу населення до радіопрограм, як і раніше, зберігала гостроту. Тому програму зі створення народного радіоприймача оголосив уже новий уряд Ракоші [22]. 
Таким чином, міжвоєнний період став зародженням угорської журналістики, заснованої на демократичних принципах. Незважаючи на авторитарну владу Хорті, в країні існували газети та журнали різних політичних спрямувань від крайніх правих до крайніх лівих. Цей досвід наслідували в дуже важливий час для угорської державності, після падіння соціалістичного ладу в період - 1989-1990рр., використовується він і сьогодні, коли в Угорщині панує практично однопартійна влада.

Багато філософських ідей, політичних та громадських концепцій, що виникли в період між 1920 і 1945 рр., знайшли своє друге народження або цікаве переосмислення в сучасному житті угорської преси.

\section{Література}

1. 1918. évi II. Néptörvény a sajtó szabadságáról https://net. jogtar.hu/ezer-ev-torveny?docid=91800202.TV\&searchUrl=/ezer-evtorvenyei\%3Fpagenum $\% 3 \mathrm{D} 38$

2. A Magyarországi Szocialista Szövetséges Tanácsköztársaság alkotmánya https://net.jogtar.hu/ezer-ev-torveny?docid=91900035.TV \&searchUrl=/ezer-ev-torvenyei\%3Fpagenum\%3D38

3.1938. évi XV. Törvénycikk a társadalmi és a gazdasági élet egyensúlyának hatályosabb biztosításáról https://net.jogtar.hu/ ezer-ev-torveny?docid=93800015.TV\&searchUrl=/ezer-evtorvenyei\%3 Fpagenum\%3D41

4. 1939. évi IV. Törvénycikk a zsidók közéleti és gazdasági térfoglalásának korlátozásáról https://net.jogtar.hu/ezer-ev-torveny ?docid=91900035.TV\&searchUrl=/ezer-ev-torvenyei\%3Fpagenum $\% 3 \mathrm{D} 38$

\section{A NYOMTATOTT SAJTÓ MAGYARORSZÁGI TÖRTÉNETE A XX. SZÁZADIG}

http://mmi.elte.hu/szabadbolcseszet/mmi.elte.hu/szabadbolcseszet/ indexa3c9.html?option $=$ com_tanelem\&id_tanelem $=545 \&$ tip $=0$

6. A magyar sajtó a két világháború között. http://www.drfeherkatalin. hu/upld/7.1.pdf

7. Budapest lexikon II. (L-Z). Főszerk. Berza László. 2., bőv. kiad. Budapest: Akadémiai. 1993. 191. o

8. Új Magyarság https://adtplus.arcanum.hu/hu/view/UjMagyarsag _1938_01/ 
9. Kútfalvy Oszkár: Újságpaloták. Bp., Akadémiai Kiadó, 1991

10. A magyarországi hírlapok és folyóiratok bibliográfiája 19211944, I. kötet (A-L), Budapest, 2010, 1888. tétel

11. Várkonyi Vilmos. Don-kanyar: A 2. magyar hadsereg tragédiája

https://www.google.com/search?sxsrf=ALeKk02bGBo3IY69G3XI UaxJBGD7oqe21A\%3A1597488260787\&ei=hLw3X6q7L8uFrwTO9r fgBg\&q $=\mathrm{F} \% \mathrm{C} 3 \% \mathrm{BC}$ ggetlens $\% \mathrm{C} 3 \% \mathrm{~A} 9 \mathrm{~g}+1944 \&$

12. Sipos Lajos: Az elérhetetlen eszmény. A Napkelettől a Magyar Szemléig. Tekintet, 2010. 5. 3-36.

13. «Hungarian newspapers». Library of Congress. Retrieved 26 May 2015.

14. Szellemi honvédelem/ https://www.arcanum.hu/hu/onlinekiadvanyok/Lexikonok-magyarorszag-a-masodik-vilaghaborubanlexikon-a-zs-F062E/s-sz-F0D5A/szellemi-honvedelem-F0DC0/

15. Új magyar irodalmi lexikon III. (P-Zs). Főszerk. Péter László. Budapest: Akadémiai. 1994. 1858-1859. O

16. A Toll (1929-1938): Repertórium https://www.amazon.co.uk/ Toll-1929-1938-Repert\%C3\%B3rium-Irodalmi-bibliogr\%C3\%A1fiai/ $\mathrm{dp} / 9637411208$

17. Nagy Csaba: Kisérletek a betiltott Szép Szó újjászervezésére, Irodalomtörténeti Közlemények - 1985. 89. évf. 4-5. füze

18. A Magyar Írás https://hu.wikipedia.org/wiki/Magyar_\%C3\% ADr\%C3\%A1s_(egy\%C3\%A9rtelm\%C5\%B1s\%C3\%ADt $\% \mathrm{C} 5 \% 91$ lap)

19. Romániai magyar irodalmi lexikon: Szépirodalom, közirás, tudományos irodalom, müvelödés II. $(G-K e)$. Főszerk. Balogh Edgár. Bukarest: Kriterion. 1991.

20. Új Szó https://en.wikipedia.org/wiki/\%C3\%9Aj_Sz\%C3\%B3

21 Néplap http://www.ujneplap.hu/

22. «От народного приемника к народному суперу. Часть 2» https://ezyk091978.livejournal.com/64547.html 


\section{3. Журналістика у період 1945-1956 років}

В Угорщині початок «соціалістичного поступу», найімовірніше, слід датувати Тегеранською (1943) і Ялтинською (1945) мирними конференціями. Саме на цих самітах керівники провідних країн антигітлерівської коаліції У. Черчілль, Ф. Рузвельт і Й. Сталін визначилися щодо майбутнього післявоєнної Свропи. Угорщина потрапила під вплив Радянського Союзу, і хотіли чи не хотіли цього угорці, їхня доля, як і доля країни, впродовж багатьох років залежала від Москви. Загалом роки радянського панування в існуванні угорської держави можна поділити на такі етапи:

1. Кінець 1944 р. - середина 1947 р. - спроба побудови країни народної демократії.

2. Середина 1947 р. - 1956 р. - насильне впровадження сталінського соціалізму, заснованому на відвертому терорі, нехтуванні будь-яких прав людини тощо.

3. 1956 р. - середина 80-х років - побудова так званого розвиненого соціалістичного суспільства.

4. Середина 80-х - початок 90-х років - підготовка повалення тоталітарної соціалістичної системи та переходу до суспільства, що грунтується на принципах демократії і ринкової економіки. Початок розвитку багатопартійної системи.

Перший етап. На звільненій радянськими військами території Угорщини в м. Сегед 2 грудня 1944 р. було створено Угорський національний фронт незалежності, до якого увійшли Угорська комуністична партія (УКП), Соціал-демократична партія Угорщини (СДПУ), Партія дрібних сільських господарів (ПДСГ), Буржуазно-демократична партія (БДП), Національна селянська партія (НСП) та профспілки. Формувалися також місцеві органи Фронту, які спочатку виконували функцію місцевих органів 
державної влади. А 22 грудня в м. Дебрецен на засіданні Тимчасових національних зборів (їх делегати обиралися відкритим голосуванням на масових мітингах) було створено Тимчасовий національний уряд, склад якого попередньо узгоджувався з Й. Сталіним. Уряд очолив Бела Далнокі-Міклош. До його складу ввійшли три комуністи, два члени ПДСГ і чотири безпартійних.

28 грудня 1944 р. Угорщина оголосила війну гітлерівській Німеччині, а 20 січня 1945 р. підписала угоду про перемир'я, згідно з якою поверталася у кордони 1937 р. До укладення мирного договору на іiі території діяла Союзна контрольна комісія (СКК) на чолі з К. Ворошиловим.

У листопаді 1945 р. відбулися вибори до Національних 3борів Угорщини на основі загального таємного голосування, які засвідчили, що народ цієї країни не бажає підтримувати ліві сили. Так, ПДСГ отримала 57 \% голосів, а УКП і СДПУ лише по 17 \%. Партія дрібних сільських господарів, розуміючи, що в умовах, які склалися, їй ніхто не дасть можливості створити самостійний уряд, пішла на створення коаліційного уряду. Новий демократичний уряд, що складався із семи осіб від ПДСГ, трьох - від КПУ, по одній особі від СДПУ та НСП, очолив представник ПДСГ Золтан Тильді. Ключові пости у цьому уряді, як і слід було очікувати, дісталися комуністам. Тому всі спроби дрібних сільських господарів повернутися як в економіці, так i в політиці до довоєнних цінностей, були марними.

1 лютого 1946 р. з ініціативи соціал-демократів Угорщину було проголошено Народною Республікою і впроваджено посаду президента. На цю посаду обрано 3. Тильди, якого на посаді прем’єр-міністра змінив представник цієї ж партії Ференц Надь. На початку 1947 р. було «розкрито» заколот Ф. Надя та інших «реакційних лідерів» ПДСГ, які ставили за мету повалити демократичний республіканський лад. Усіх учасників «заколоту» заарештували. Звичайно, за таких умов підтримувати опальну партію було небезпечно, але ПДСГ усе ж отримала на виборах у серпні 1947 р. 68 мандатів (у 1945 р. - 177). Завдяки маніпуляціям, проведеним міністром внутрішніх справ, комуністом Л. Райком, комуністи отримали на виборах 22 \% голосів (100 місць), що в тих умовах робило їх найбільшою партією в 
парламенті країни і дало можливість захопити всі головні посади в уряді [1 с. 476].

Відтоді починається другий етап. У червні 1948 р. комуністи об'єдналися із соціал-демократами та утворили Угорську партію трудящих (УПТ). Нова партія взяла за основу принципи марксизму-ленінізму, а також «вчення Сталіна», розпочала класову боротьбу з іншими партіями, в результаті чого практично всі інші партії припинили свою діяльність. У країні утверджується партійно-тоталітарна держава 3 міні-Сталіном - першим секретарем ЦК УПТ і главою уряду М. Ракоші, який разом із соратниками повернувся на батьківщину 3 московської еміграції. Розпочалося бездумне копіювання радянської моделі. Впровадження планового господарства, насильницька колективізація на селі, створення військово-промислового комплексу, в який було вкладено величезні кошти, Угорської народної армії, неприкрите адміністрування з упровадженням у повсякденне життя культу особи М. Ракоші, боротьба з релігією, викоренення національних традицій. Усе це разом призвело до того, що становище більшості населення погіршувалося з кожним днем.

У країні відбулися численні чистки, жорстоко придушувалася будь-яка політична опозиція партійному режимові М. Ракоші. Розпочалися показові політичні процеси, боротьба за владу всередині бюрократії, нічні вилазки й операції таємної поліції, переслідування і репресії. Тільки у 1952-1956 рр. в Угорщині було засуджено 1136434 осіб, більше половини з яких були засуджені до тюремного ув'язнення. Майже чверть населення перетворилися на інформаторів або поліцейських донощиків. Усе це визначало внутрішньополітичний клімат у країні [2].

Конфлікт, що назрівав в угорському суспільстві, змусив керівництво КПРС у червні 1953 р. запропонувати М. Ракоші відмовитися від посади глави уряду, залишаючись при цьому першим секретарем ЦК УПТ. Прем'єр-міністром був призначений I. Надь, який користувався великим авторитетом у народу. В політичному житті Угорщини виявилися перші ознаки «відлиги», зокрема, почалися акції реабілітації незаконно засуджених, активізувалася діяльність громадських організацій. В економічному житті розпочалися реформи в сільському господарстві, у 
промисловості більше уваги стали приділяти випуску товарів широкого вжитку. Однак процес демократизації не зміг розгорнутися на повну силу. У квітні 1955 р. І. Надя було усунуто $з$ посади прем'єр-міністра, а в грудні - виключено з партії. Знову почалося «похолодання». Утім, спроби відновити колишні методи управління країною зустрічали посилений опір. На підтримку реформ активно виступала інтелігенція.

I. Надь згрупував навколо себе опозицію, яка виступала проти диктату М. Ракоші. Ситуація в країні загострилася, про що посол СРСР в Угорщині Ю. Андропов інформував Москву.

До Будапешта зачастили високі московські контролери: М. Суслов, А. Мікоян. Так, М. Суслов під час однієї з поїздок звернув увагу й на те, що в кадровій політиці УПТ «великі ненормальності»: на керівну роботу рідко висуваються особи угорської національності. «Під прапором залучення до керівництва авторитетніших і досвідченіших кадрів, серед яких переважають товариші єврейської національності, - наголошував Суслов, - $є$ тенденція ще більше відсунути від керівництва молоді кадри угорської національності» [3, с. 110].

В угорському керівництві зміна політичних фігур відбулася через кілька днів. Однак місце Ракоші зайняв не I. Надь, а ненависний народу Е. Гере [4, с. 9], який до 1945 р. очолював у Парижі компартію у вигнанні, а потім разом із Ракоші проводив хибну економічну політику і чинив репресії наприкінці 40-х на початку 50-х років. Гере пообіцяв провести політичні реформи, звільнив кілька сотень політичних в'язнів. Однак ці кроки нового керівника партії не викликали великої довіри більшості населення. Кількість невдоволених, насамперед серед молоді, росла.

Зрештою Гере був змушений реабілітувати колишнього керівника Угорської компартії Л. Райка, якого було страчено, і його прихильників. Це була одна з основних вимог «гуртка Петефі» після того, як вдова Л. Райка привселюдно виступила 3 вимогою його реабілітації і покарання вбивць. 6 жовтня 1956 р. відбулося пишне державне поховання Райка і трьох його сподвижників [5, с. 144].

Після закінчення Другої світової війни громадяни Угорщини 
жили надією на докорінні суспільно-політичні зміни, розраховували вони і на свободу та незалежність преси. Після того, як була знищена галаслива й агресивна пропагандистська машина Салаші, потрібно було створювати нову медіаполітику. Дослідники історії преси цього періоду зазначають, що у цій царині на початку панував інформаційний вакуумом. Так, наприклад, з 1944 року, кількість опублікованих газет була менше десяти.

Ще один головний гравець у системі 3МI - радіо мовчало місяцями, професійна служба новин, а також ії флагман - УТА також лежало у руїнах.

Правове середовище, яке регулювало життєдіяльність преси та забезпечувало здійснення свободи думок, знаходилося у руйнації. Старі закони не працювали, а нові ще не були створені. До народження органів нової угорської державності, Тимчасових національних зборів у Дебрецені та формування національного уряду, окупаційні радянські війська прагнули створити органи преси в країні й регулювати їх діяльність.

Для побудови демократичної держави надзвичайно важливим було створення умов для вільного існування 3МІ. Тому прем'єр-міністр Угорщини в 1944 році Бела Міклош Дальнокі вніс на порядок денний першого засідання Кабінету Міністрів 23 грудня 1944 року питання про забезпечення діяльності преси.

У преамбулі Закону № I 1946 р. «Про державну форму Угорщини як одне 3 «природних і невідчужуваних» прав громадянина є право на вільне вираження власної думки [6].

Після прийняття цього закону, уряд вжив низку заходів для забезпечення видання періодичних видань, а також щодо впливу на медіасистеми. Нормативно-правова база щодо преси того часу носила досить маргінальний та технічний характер, але головне, що вони не обмежували свободи думок.

У той же час, це законодавство не сприяло функціонуванню збалансованої, плюралістичної преси. Більш того, воно сприяло блокуванню прагнень опозиційних партій, які не входили в коаліцію, створити свої пресоргани.

Із настанням пролетарської диктатури, комуністичної монополії на владу, коаліційна система 3МІ була скасована. Прийняття у 1949 році лицемірної, безглуздої та антисвободівської 
сталінської конституції повністю скасувало право громадянина на свободу думок.

У перші години після звільнення Будапешта вийшов номер газети «Сабадшаг». 25 березня читачі змогли побачити перший номер газети «Сабад неп» 3 підзаголовком: «Третій рік видання». Уся справа в тому, що газета почала своє існування ще в 1942 році, будучи тоді підпільною. «Сабад неп» зразка 1945 року складалася з 4-6 сторінок і друкувалася накладом близько 140-150 тис. примірників.

Саме в цей період зацікавленість публіки до преси була особливо значною, що було пов'язано з високим рівнем інтересу угорців до суспільного і політичного життя. Треба зазначити, що найбільшою підтримкою громадян у післявоєнні роки користувалася Партія дрібних сільських господарів (ПМСХ). Виданням, яке відстоює її позиції, була газета «Кіш уйшаг», з якою часто полемізувала Szabad nép.

Органом ще однієї популярної партії-соціал-демократичної - була газета Népszava, яка виходила накладом у 100 тис. примірників. Національно-селянській партії допомагала Szabad zi.

У перші роки після звільнення преса Угорщини була дуже різноманітна і неоднорідна, що разюче відображало наявність багатопартійності.

До 1945 року угорський ринок щоденних газет демонстрував надзвичайно багатоманітну картину. Між двома світовими війнами були опубліковані сотні політичних щоденників і щотижневиків, у столиці було видано два десятки часописів.

За винятком крайніх лівих, кожна політична течія могла видавати власні газети - ранкові, денні та вечірні, які змагалися між собою. Якісні газети та таблоїди добре поєднувалися одне 3 одним.

322 вересня 1944 р. по 11 квітня 1945 р. Угорщина перебувала під подвійною військовою окупацією. Радянська армія мала всі ресурси країни для управління пресою. У цей період тільки з дозволу радянської влади можна було друкувати місцеві газети невеликими тиражами. Перша така газета угорських комуністів вийшла під назвою Népakarat, опублікована 15 жовтня 1944 року в Орошазі. 
18 жовтня 1944 року вийшли ще дві газети, видані групою Сентес Угорської партії комуністів Magyar Népakarat та Ceгедські комуністи Szegedi Népakarat. Четвертою газетою стала Vásárhely Népe, яку видавали в Годмезьовашархей [7].

Перші газети можна було опублікувати лише в невеликій кількості та за надзвичайно складних умов. Папір, фарбу, гас мали просити від Червоної армії. Тим часом, часто не було електрики, друкарні не працювали. Недарма маленькі газети опублікували лише кілька номерів: лише 5 випусків Magyar Népakarat в Орошазі та 9 Szegedi Népakaratot [8].

Через місяць під егідою Угорського національного фронту незалежності була видана газета Délmagyarország, часопис став провідним органом радянської окупаційної влади та угорських комуністів. У ній, поруч з пропагандою Червоної Армії, публікувалися статті про роботи з відновлення народного господарства, ремонт житлового фонду [9].

Як тільки бойові дії на стороні Пешта в столиці закінчилися, наступного дня Дарваш Джозеф, Дюла Калай та Лайош Зілахі видали газету Szabadság, вона також знаходилася під контролем комуністів.

На той період існувало правило, що лише партія, міністерство або громадські організації отримували дозвіл на видання друкованого органу.

Газети коаліційних партій виглядали таким чином: Népszava (соціал-демократи), Szabad Nép (Угорська комуністична партія), Szabad Szó (Національна селянська партія), Kis Újság (Незалежна партія дрібних хохяїв), Világ (Громадянська демократична партія). A Független Magyarország, A Reggel, Kossuth Népe офіційні газети Міністерства оборони, az Új Szó газета Червоної apмiї. Világosság, a Haladás газета Угорської радикальної партіï, Fáklya - щотижнева газета Громадянської демократичної партії.

Газета Új Magyarország, спеціалізувалася на оглядах світової політики та економіки.

Видання газет у церквах здебільшого обмежувалося. Католицька церква мала загалом дві щотижневі газети - Új Ember, Szív та журнал Vigilia, він отримав ліцензію на публікацію 43 
номерів на рік, хоча в 1939 р. мав 55.Окрім національних газет, конфесійних єпархій, освітні та соціальні заклади також видавали газети. Регулярно видавали свою пресу реформати, лютеранська, а також єврейська преса.

Отже, у цей період масмедіа працювали в основному як газети для коаліційних партій, але кількість членів партії та кількість примірників значно відрізнялася. Формування громадської думки, найважливішим інструментом якої $є$ преса, проходило на тлі боротьби між партіями. У різних статтях та звітах вони сперечалися, критикували один одного, здійснювали партійну пропаганду і мобілізували існуючих симпатиків.

Більшість партій вказали приналежність своїх газет у їх заголовках. Угорські комуністи, навпаки, намагалася показати коаліційний характер своєї газети, тому використали у заголовку слово - «демократичний». За винятком комуністичної преси, якою керував Йожеф Ревай військовими методами, інші партійні газети здобули високий ступінь самостійності, у багатьох випадках з незалежною програмою та стилем.

Соціал-демократична газета Népszava після війни знаходилася у тяжкому стані. Багато їі журналістів стали жертвами режиму, загинули в нацистських концтаборах, інші були призвані в угорську армію і там полягли. Однак, ще більшою проблемою для соціал-демократів було, якою має бути їхня співпраця з комуністами.

Комуністична Szabad Nép - під керівництвом Йожефа Ревай і згідно з його планами - чітко присвоїла собі роль лідера лівої преси, вона намагалася відсунути Népszava на другий план.

31946 року розпочато випуск Társadalmi Szemle - щомісячного теоретичного журналу Комуністичної партії, серед його організаторів були: Йожеф Ревай, Ерн Гер Дьордь Лукач. Спочатку проаналізувавши прийняття радянських доктрин та основні принципи організації партії, вони організували на його шпальтах дискусію щодо значення «соціалістичного реалізму» [10].

У квітні 1945 року в Дебрецені був заснований журнал Magyarok, який незабаром переїхав до Будапешта. Спочатку засновником була компанія Ady у Дебрецені, а з жовтня 1946 р. 
Будапештський інститут літератури. Вітальну статтю написав редактор Геза Юхас. Спочатку вони наважилися розкритикувати марксистську інтерпретацію Аді Йозефа Ревая, роздуми Джорджа Лукача про роль фундаменту та надбудови в літературі тощо.

Одна з найяскравіших щомісячних газет доби, Válasz, була відновлена в жовтні 1946 року, продовжила серію періодичних видань, перерваних війною, під редакцією Дюли Іллієса. Вони працювали з авторами, кращими представниками угорської літератури того часу: поетами Золтаном Джекелі, Іштваном Шінка, Лерінкою Шабо, Іштваном Ваш, Шандором Вереш. Серед письменників були: Янош Кодолані, Ласло Немет, Пал Шабо, Петер Вереш.

Основним ідеологом журналу був Іштван Бібо, який розробив концепцію третього пасажира (наприклад, у січневому номері 1947 р.) зробив це проти марксистської ідеології [11].

У період з 1946 по 1948 роки виходив журнал Puszta Népe, який соціографи вважали своїм професійним часописом, його головним редактором був Міклош Галяші.

У 1946 році у Дебрецені був опублікований журнал Holnap, під редакцією Ласло Вайди.

Гумористичні журнали також поповнили палітру угорської преси, серед них користувалися особливою популярністю Ludas Matyi, Pesti Izé та Apolló-kabare.

У першому випуску, Apolló-kabare, який вийшов 20 травня 1945 року, Угорська комуністична партія була розкритикована першою, жарти про Радянську Раду також були опубліковані на восьми сторінках часопису. Цей журнал на початку мав кількість примірників - 200, а вже протягом декількох років, незважаючи на брак паперу, 400 000, а на піку - 650 тис.

Szabad Száj був започаткований 22 червня 1946 року також як гумористичний журнал, його редактором був соціал-демократ Дежо Кірай. Гумористичні твори та карикатури журналу на події щоденного життя створювалися опозиційними авторами. Ось чому його закрили 15 березня 1951 року.

Наступним гумористичним журналом був Pesti Izé , який очолив Дьордь Гал. На потуру публіки він допускав жарти 3 
легкими еротичними малюнками, ув'язуючи це 3 комуністичною ідеологією. Звичайно, така фривольність не сподобалася керівництву партії, і 10 жовтня 1948 журнал закрили [12].

Перші два-два з половиною роки епохи коаліції разом із усіма їі темними сторонами були «золотим віком» для угорської преси. 3 приходом до влади комуністів були розігнані партії та ліквідовані різні газети й журнали.

Дежо Шульок, лідер Угорської партії свободи, був першим у 1947 році. Його газета Holnap була ліквідована грубою та непрозорою маніпуляцією. На сторінках цього часопису викривалися зловживання комуністичних лідерів і профспілкових функціонерів, писали про злиденне життя робітників та селян. Влада використала нагоду позбавити журнал ліцензії під час перереєстрації на майбутній період, зробивши його «неіснуючим». Тим самим часопис було виключено з листа розповсюдження, більш того, була дана команда друкарям його не друкувати [13].

У 1948 році кількість газет скоротилася. 3134 органів залишилося тільки 8 провінційних газет та 11 центральних. Сім адміністративних районів отримували лише один тижневик.

Управління повітовими газетами перебрали на себе партійні комітети. Замість закритих щотижневих газет і журналів на початку 50-х було започатковано набагато менше нових видань, але й ті знаходилися під суворим контролем.

Редакції були об'єднані та сформовані у суворо централізовану пресову структуру, яка майже не змінювалася до зміни режиму в кінці $90-$ х років. Внутрішня ієрархія редакцій нагадувала військову структуру. Роботу журналістів, редакторів, оглядачів, а іноді й головного редактора перевіряв, чи відповідає стаття політичним вимогам, спеціально представлений партійний контролер.

Поряд 3 головним редактором працював комітет, який мав дві форми: в одній над редакцією працювала редакційна комісія, як правило, заступник головного редактора або випусковий редактор, у другій - секретар партійного комітету, в інших редакціях були сформовані спеціальними органами контрольні комісії.

У той же час, наступ на свободу преси супроводжувався зна- 
чним погіршенням журналістських стандартів. Про це найкраще свідчать дані про освіту кореспондентів. Серед них вищу освіту мали трохи більше $25 \%$. У центральних газетах третина журналістів навіть не мала бакалаврської освіти.

Редакція Szabad Nép організувала окрему ідеологічну освіту. При цьому, наприклад, у 1955 році 12 працівників навчалися на заочному відділенні партійної школи, а двоє - у марксистськоленінському вечірньому університеті Будапештського комітету партії.

На вершині ієрархії стояла газета державної партії Szabad Nép, зроблена за зразком радянської «Правди».

Відповідно до марксистсько-ленінського вчення газета повинна була стати «своєю» для всіх окремих класів і верств населення. Ї̈̈ функція повністю відрізняється від сьогоднішніх часописів, вона друкувала лише новини, не пояснюючи внутрішньополітичні події та обгрунтування тих чи тих дій влади.

Szabad Nép. 3 кінця Другої світової війни і до революції 1956 р. відігравала важливу роль у політиці комуністичної партії. Людей, окрім радіо, інформувала переважно щоденна преса, виконуючи консолідуючу роль у суспільстві. Рада міністрів Угорщини на відзначення 10-ї річниці Szabad Nép оголосила 1 лютого кожного року Днем преси.

Szabad Nép друкувалися величезними тиражами, іï доставляли в більшість робочих місць, та перед початком роботи обов'язково проводилися політінформації, на яких читалися найважливіші статті [14].

Після того, як Соціал-демократична партія була поглинена Комуністичною партію, Népszava за зразком радянської газети «Труд» стала профспілковим часописом. Керівництво Угорської робітничої партії вигнали із Népszava тих журналістів, які виступали проти об'єднання двох робітничих партій, а тих із них, хто підтримав цей крок, перевели до Szabad Nép частково тому, щоб вивчити правила нової комуністичної преси, а частково, щоб позбавити їх впливу на нових колег, а також на свою читацьку аудиторію.

У цей період видавалися газети Friss Újság - для селянства, Magyar Nemzet - для інтелігенції, Nap - для молоді та Народної 
apмiï. Világosság з 1952 року - видання Будапештського комітету партії та Столичної міської ради, Esti Budapest була щотижневою газетою угорських письменників, як і Irodalmi Újság. Дитячі журнали також друкувалися за радянським зразком. Радянський еквівалент «Мурзилки» в Угорщині отримав назву Pajtás.

Політичні події мали публікуватися однаково у всіх газетах, тексти направлялися з Угорського телеграфного агентства з прямою вказівкою зберігати новини без змін.

3 усіх питань, порушених політичним керівництвом (наприклад, трудові змагання, боротьба за мир, міжнародна змова проти соціалізму, боротьба за високі результати на виробництві), статті з'являлися в газеті комуністичної партії Szabad Nép, а потім передруковувалися в інших часописах відповідно до власних напрямків.

До 1956 року 40-50\% журналістів були членами компартії, таким чином, вони автоматично ставали частиною владної системи, з них вербували інформаторів та лояльних людей [15].

Після націоналізації преси домінували не професійні чи літературні міркування, а ті, що забезпечували потреби тотальної пропаганди. Основна мета полягала не в інформуванні населення, а маючи монополію на інформацію, надавати через цензуру дозовані новини, а то і поширювати неправдиву інформацію. При цьому влада виходила з того, що чим нижчий стандарт на інформацію про суспільне життя, тим простіше керувати та впливати на населення.

Техніка пропаганди застосовувала п’ять принципів:

1) Принцип спрощення: спрощення всіх факторів добра i зла, друга і ворога, проста формула (буржуазія - робітничий клас, імперіалісти - Радянський Союз тощо). Суспільство вони сприймали як натовп людей, реакції та поведінку яких можна передбачити й, відповідно, намагатися впливати та контролювати.

2) Принцип тенденційності: вкрасти в опонента кредит довіри, зробити на нього грубий наклеп, при цьому ще і глумлячись (наприклад, засуджені в судових процесах не тільки звинувачувалися у змові проти держави, але й у кримінальних злочинах, були опубліковані карикатурні малюнки про них, висміювалися 
їх фізичні вади, походження, імена тощо). Образ ворога повинен був показати його диявольський характер і моральну пустоту.

3) Принцип трансфузії: загальноприйнятні цінності у суспільстві використати у власних цілях 3 можливим перекручуванням їх суті.

4) Принцип одностайності: позиція та погляди простої людини повністю збігаються $з$ лінією партії. Прості робітники, селяни думають так, як і відомі громадські діячі (наприклад, існували так звані щоденники поштової скриньки, де навіть простий підсобний працівник правильно називав генеральну лінію партіï).

5) Принцип оркестрації: та чи та інформація нескінченно повторювалася в різних інтерпретаціях та оркестраціях [16].

Для посилення контролю над діяльністю преси були розроблені певні правила, які регулювали зміст друкованих видань:

1) цитата з праць чи виступів лідера партії та держави або класиків марксизму-ленінізму, переважно Леніна, Сталіна та Матяша Ракоші;

2) вивчення цитати, обговорення іiї значення;

3) проведення мозкового штурму, який замінює уявлення про реальні чи уявні явища, неконтрольовану статистику, невідомі більшості техніко-наукові терміни;

4) перекладення відповідальності. Непогрішимих лідерів не можна звинувачувати в жодній із проблем, які виникають у суспільстві. У всьому винні підступні дії зовнішнього і внутрішнього ворогів, лінивих співвітчизників, проступки нерозумних людей або з певні об'єктивні труднощі;

5) оптимістичні вказівки щодо подолання труднощів. У цей час у пресі провідне місце зайняла так звана агітація про щасливе життя, тобто наголос на те, що люди щасливі в соціалістичному суспільстві й наскільки вони задоволені своєю долею;

6) натхненний висновок: за допомогою лідерів угорський народ подолає всі неприємності та збудує соціалізм. Ось так і прийде економічне процвітання та добробут [17].

Газети на постійній основі друкували звіти про успіхи в промисловому виробництві та сільському господарстві. У го- 
ловного редактора Esti Budapest у кабінеті на стіні висіла карта країни, на якій червоними прапорами було позначено ті підприємства, що вони вже відвідали та підготували пропагандистські матеріали.

Вони також намагалися оволодіти партійною мовою. У газетних статтях комуністичні журналісти використовували слова: «передовиця», «свобода», «демократія», «мир». 3 іншого боку, ворог може бути лише «реакційним», «фашистським» i «ворогом народу». В той же час, вони намагалися стерти з суспільної свідомості такі поняття, як Бог, нація, родина, молитва, церква, спасіння, любов до ближнього тощо. Слова, які ще могли функціонувати, але їх можна було включити лише до нових словосполучень: «передова традиція», «соціалістичний патріотизм», «соціалістична мораль», «просунута інтелігенція» тощо.

Заголовки також були надзвичайно мальовничими, як правило, стосувалися Маркса, Енгельса, Леніна та Сталіна.

Як приклад, на перших сторінках газет були такі назви: «Сила робітничо-селянського союзу», «Всі зусилля для збільшення виробництва!», «Більше уваги до кадрової роботи!» [18].

Суспільство сприймалося як натовп, чию реакцію та поведінку можна контролювати й впливати на неї на основі запропонованих моделей. За допомогою кліше, модних слів, слоганів вони прагнули маніпулювати масами.

Вони навіть прагнули переробити граматику. В роботах того часу ми можемо знайти такі твердження: «Коли починається побудова соціалізму, в історії мови також є нова ера», «Вивчаючи нову еру нашої мови, для угорських лінгвістів взірцем слугує вчення товариша Сталіна на прикладі Радянського Союзу».

Як засіб маніпулювання, деяким поняттям дали нові назви, наприклад, угорці, які втекли за кордон, стали не «емігрантами», а «дисидентами» [19] Були створені нові слова: пильність, флаєр, організація масовості, основний орган, політичний комітет, центральне керівництво, більшовик, меншовик, народний уповноважений, братська партія, довіра, охорона праці, дошка оголошень, збори делегацій, робочий рух, виробничі відносини, стахановець, водій комбайна, жива фабрика, орендне житло, куркулі, бригада, агітація, кадри, мирна війна, мирний та- 
бір, культурна революція, сволота, студент з життя, товариш, домагання, диспетчер, експлуатація, станція, майно, товариш, агітпроп тощо.

Через закритий характер ідеологізованої мови та дефіцит виразів, безперервні повтори слів інформаційний зміст речень був недоброякісним, використання окремих слів лише на потурання традиції, яка з'явилася, не давала змогу зрозуміти, що хотів сказати журналіст.

Між 1949 та 1953 роками складалося враження, що журналісти наслідували стиль військових підручників: «виробничий фронт «,»виробничі баталії «, «сільськогосподарський фронт «, «культурний фронт «, «робочий фронт «, «війна миру «. Статті закликали «робітників до штурму «. Виробництво було битвою, і будь-які промахи в роботі прирівнювалися до атаки противника. «Ми всі члени табору миру» - і за вказівкою партії повинні продовжувати боротьбу за мир. 3 «внутрішнім ворогом» потрібно було постійно воювати, завжди потрібно було «боротися» проти чогось [20]. Тільки один приклад із практики редакцiï Dunántúli Napló, назва статті: «Жінки MNDSZ у Сентласло ведуть активну боротьбу за мир». Відповідно до сталінських принципів, список тих, що підлягають ліквідації, розширюється і в Угорщині: «реакціонери», члени колишнього правлячого класу, джентльмени-християнський середній клас, куркулі, середні та багаті селяни, власники млинів, середняки, що коливаються, приватні виробники, міщани, бюрократи, підозрілі інтелектуали, священики, парафіяни, агенти імперіалістів, люмпен-пролетарі, троцькісти, тітоїсти, сіоністи, космополіти, націоналісти, вороги табору миру, «псевдофашистські» соціалдемократи.

Партійна бюрократія також виробила власний жаргон. Як правило, це в основному вжиті неправильно або спотворені слова. Цим користувалися партійні ватажки, та цю лексику, порабськи, переймали підлеглі: «міжнародна ситуація загострюється», «вимірює імперіалізм», «потрапляє туди», «обговорює», «ведіть переговори», «критично аналізуйте», «ми досягли великих успіхів», «за партійною лінією», «вузькі інтереси», «поставив питання на перший план», «підняв область», «відіграє 
важливу роль», «робота на високому рівні», «основні цілі виконані». Найяскравішими є такі слова та фрази, як, наприклад, на «лінії», «партійному полі», «значення», «назустріч», «форми» тощо [21].

Деякі статті про виробництво рясніли загальними фразами та ідіомами. У повсякденну журналістську практику ввійшло повторювання висловлювань Ракоші, які, на його думку, були дотепними або популярними: «Прийдіть за тим, за чим ви повинні прийти, майбутнє наше!», «Залізний кулак робітничого класу доведе всім його правоту», «У нас є витвір честі та слави«, «Ми з’їмо курку, яка завтра знесе золоте яйце».

Статті про виробництво часто були досить трагікомічними. Ось наприклад, уривок з опусу під назвою «Збільшимо виробництво молока!»: «Однією з умов цього є те, що нам потрібно виробляти набагато більше молока, ніж раніше. У нас є всі передумови для збільшення виробництва молока (...) Для того, щоб виробляти більше молока, партійні організації дають пораду розширити якомога ширший спектр роботи з просвітництва та зрозуміти, що це, вважайте, збільшення виробництва молока серцем кожного господаря корів. Можливість є всюди - тому необхідні дії».

До медіалексикону міцно ввійшли різні прикметники: Радянський Союз називався лише з «подякою», «любов’ю», «ведучи прикладом», «самовідданим», «дружнім» тощо. Слова: «робочий клас», «герой», «хоробрий», «великий», «провідний» тощо.

Матяш Ракоші: «Товариш Сталін - найкращий угорський вчитель«, «випробуваний», «далекоглядний», «коханий», «мудрий керівник», «головний архітектор наших будівельних робіт», «улюблений лідер нашої партії», «наш заохочувач», «наш улюблений батько», «коваль нашого успіху», «вогнемет», «блискучий», «впевнений керманич» тощо.

Значні зусилля також були докладені до пропаганди Радянського Союзу. У великій кількості публікувалися твори радянських письменників, поетів, учених, пропагандистів. Одна за одною після 1949 року була опублікована радянська пропаганда угорською мовою. 
Газети: «Дівчата - жінки», «Факел», «Радянська література», «Радянський Союз», «Радянська культура», «Радянський огляд архітектури», «Радянське село», «Радянські люди», «Радянська молодь», «Радянський художник», «Радянська історія мистецтв», «Радянська етнографія», «Радянська лінгвістика», «Радянський медичний звіт», «Радянська археологія», «Огляд радянської текстильної промисловості», «Радянська хімічна промисловість», «Огляд радянських газет», «Збірник радянських юридичних статей», «Радянські новини» тощо.

В Угорщині також існували установи, які займалися радянською пропагандою. До 1955 року діяло спеціальне представництво Всеросійської організації дружби, що пропагувала радянську культуру в Угорщині.

Радянський експортфільм брав участь у розповсюджені радянських фільмів в Угорщині, а Радянське інформаційне агентство публікувало на постійній основі інформацію про Радянський Союз в угорських газетах і журналах.

Після смерті Сталіна 5 березня 1953 року в радянському керівництві розпочалася боротьба за владу, яка, у свою чергу, дестабілізувала політичну ситуацію у соціалістичному таборі. Наступником Сталіна на чолі Ради Міністрів став Маленков.

Корінні трансформації відбулися і в угорському керівництві. Ракоші був замінений прем'єр-міністром Імре Надьом. Однак боротьба за владу ще була не закінчена, тому що Ракоші залишився першим секретарем ЦК партії, а Ерне Гер - найвпливовішим віцепрем'єр-міністром, а також міністром внутрішніх справ. За лаштунками почалася жорстка, відчайдушна політична боротьба між реформатором Імре Надьом і сталіністами, що підтримували Ракоші.

У липні 1953 року Імре Надь зробив радіовиступ до парламенту - у формі урядової програми, в якій він оголосив про нову економічну політику, що знімає навантаження із селян, 3 виробничих кооперативів, скасовує виселення та інтернування, впроваджує більше терпіння в релігійних питаннях. Виступ нового прем'єр-міністра, зміст, форма й стиль промови вигідно відрізнялися від його опонентів і викликали симпатію у населення країни. 
Коли політичне керівництво розкололося на два конкуруючі табори, той самий процес відбувся також серед журналістів. Деякі з них підтримували Імре Надя та його нову політику, але більшість продовжувала наполягати на керівництві Ракоші. Журналісти Szabad Nép через день після засідання центрального виконавчого комітету Угорської трудової партії повідомили про новий політичний напрям. Кореспонденти газети вже відчули, що відбудуться зміни після смерті Сталіна. Наприклад, підбурювання до пропаганди проти Югославії припинено.

13 січня 1953 року газета радянських комуністів «Правда» надрукувала статтю про «Сіоністську медичну групу вбивць». 15 січня ц.p. Szabad Nép також повідомили про це, зазначивши, що ця група була розкрита радянськими органами державної безпеки: «Підбурювачі жорстоких вбивць перебувають у Вашингтоні. Лікарі-вбивці були найнятими агентами іноземних шпигунських служб, і більшість учасників терористичної групи були пов'язані $з$ міжнародною єврейською буржуазнонаціоналістичною організацією та американським ЦРУ». В той же час повідомлялося, що 266 з них були визнані невинними й звільнені.

У Szabad Nép Міклош Гімеш, Петер Кенде, Пал Лочеi, Янош Корнаі, Шандор Новобацький, Шандор Фекете, Тібор Мерай повідомили про свою підтримку нової політичної лінії Імре Надя, Сталінський табір Ракоші керували Оскар Бетлен та Імре Комор. Оскільки Оскар Бетлен не зміг належним чином керувати газетою, ЦК Угорської трудової партії влітку 1954 року замінив його на Мартона Хорвата, який, тактовно, не приєднався до жодного з угрупувань.

20 жовтня 1954 року Імре Надь опублікував у Szabad Nép статтю, в якій повідомив про те, що реабілітовані комуністичні лідери були невинні, включаючи звільнення Яноша Кадара влітку того ж року. Прем'єр-міністр запропонував членам партії брати участь у розробці політики партії [22].

Резолюція на користь нового напрямку в діяльності уряду була прийнята Szabad Nép 22-23 та 25 жовтня 1954 року була оголошена на партійних зборах редакції, де журналісти протестували проти цензури. Петера Конде, який був міжнародним 
редактором газети, у своєму виступі сказав: «Давайте завжди говорити правду!». Ці слова особливо стали незабутніми.

Члени редакції вирішили надіслати протокол зборів до Центрального Комітету Угорської трудової партії, Угорського радіо, УТА та національної газети. Коли спецслужби вилучили протокол, журналісти надрукували 200-300 його примірників та розповсюдили в Будапешті. Таким чином, протокол прочитали багато людей, і його вплив швидко поширився в інтелектуальних колах столиці [23].

Однак керівники редакціï Népszava рішуче виступили проти цих пропозицій. Як дисциплінований солдат партії, на партійних зборах профспілкової газети прозвучало: «Вимагати повну чесність означає анархію (...) У нас є державна таємниця тощо. Можуть виникнути питання,

Час яких ще не настав. Наприклад, недоречно коментувати югославське питання передчасно. Це не означає недовіру, якщо партія навіть не хоче щось коментувати. (...) Якщо ми скажемо, що все повинно бути підпорядковано питанню сили робітничого класу, то ми можемо це зрозуміти - про певні питання не можна писати відразу, бо це завдало б шкоди політиці партії. Все це залежить від того, чи служить журналістика силі робочого класу» [24].

24 листопада 1954 року на засіданні Центрального комітету Угорської трудової партії партійні лідери засудили резолюцію Szabad Nép «Проти партії, проти її ЦК: вони заявили, що редакція Szabad Nép не повинна проводити власну політику, а повинна доводити політику ЦК до вільних людей».

У листопаді 1950 p. Irodalmi Újság виходила, взявши за приклад «Літературну газету» СРСР. Ї̈̈ головний редактор - Бела Іллас, комуніст, письменник-гуморист, який так прославляв Матяша Ракоші у своїй статті: «Слово Ракоші - це слово істоpiï, віха, маяк, двигун багатьох сотень мільйонів кінських сил». Biн $з$ гордістю заявляв, що Irodalmi Újság - єдиний угорський літературний часопис, який не опинився на баржі правих опортуністів.

Irodalmi Újság змінила свій стиль 31953 року. Журналісти підтримали лінію Імре Надя на реформування економіки, у той 
же час, вони зображали жалюгідну реальність сільського життя, за що отримували жорстку критику від прихильників Ракоші. Серед комуністичних журналістів усе більше ставало прихильників програми Імре Надя. Хоч були такі, які боялися, що переможе лінія ЦК партії.

Цікавим є такий приклад. Молодий поет Шандор Цоурі, якого партія направила вчитися в університет в Будапешті, після благополучного життя у столиці поїхав додому до свого села та $з$ жахом побачив, яке там тяжке життя. Все пережите він виклав на папері: «Я жив із захопленням про наш лад і не бачив, який тягар впав на плечі мого народу, доля якого є тяжкою... Заробітна плата затримується, селянин, який вирощує урожай, живе злиденно».

У газеті Nyírségi Naplója поет Петер Кучка пише про стан у країні та розрив між ідеєю і реальністю. Стаття, у якій говориться про переживання поета, розповідає, як він зустрів прокляте селянськими жінками життя, недоїдання, відсутність можливості купити ліки дитині, немає надії на захищену старість.

Саме ці публікації породили серед інших початок «заколоту письменників». У своїй статті Пал Сабо, яку він сформулював у дусі завдань для письменників Імре Надя: «Після заяви нового Голови Ради Міністрів світ письменників глибоко похитнувся (...) нарешті, ось новий економічний порядок, який зняв усі негаразди з письменника, а отже, і з літератури. Дорога вільна, доріжка вільна (...) Так, сталося так, що вона розгортається майже до горизонту перед творчістю кожного письменника та поширюється на творче життя. Поле творчості стає майже безсмертним, і віднині до завтра бетонні стіни перетворюються на скляні» [25].

У той же час боротьба у владних верхах віддзеркалювалася й у Irodalmi Újság - 3 одного боку, Illés Béla головний редактор, який боявся Москви, після публікації кожного випуску тремтів зі страху перед ракошівським керівництвом. 3 іншого боку - табір письменників та журналістів, що підтримували Велику програму та свободу преси Імре Надя. Один із представників цього табору Тібор Дері надрукував відкритий лист товаришу 
Імре Надю 23 жовтня 1954 року на головній сторінці Irodalmi Újság [26].

Як тільки в Москві був заарештований найбільший ворог Матяша Ракоші Берія, він розпочав свою контратаку. В 1955 р. ЦК Угорської робітничої партії відсторонив Імре Надя від посади голови Ради Міністрів Угорської Народної Республіки.

Після чого миттєво розпочалася атака на журналістів, що підтримували Імре Надя. Ракоші заявив, що «Преса повинна бути готовою для боротьби зі зростаючою правою загрозою. Це стосується насамперед Szabad Népre та Magyar Nemzetre».

Низка журналістів були вигнані з роботи 3 газети Szabad Nép, насамперед звільняли тих, хто працював у редакції в сорокових роках. Було призначено практично нових співробітників редакції. Головний редактор Іван Болдіжар та декілька інших журналістів були вислані 3 країни. Інших журналістів виключили з редакції, відправляли жити в сільську місцевість чи за кордон.

Незважаючи на часті атаки на газету Irodalmi Újság у день iï появи рано-вранці люди стояли довгою чергою біля газетних кіосків, щоб ії купити. Епіграми Ласло Бенджаміна були більш гострими, ніж зазвичай, а поети Хандабаса та Лайоша Конья у своїй поемі глузували з міністра культури Юзефа Дарваша.

Дьорджи Нонн, заступник міністра народної культури, за дорученням партійного керівництва конфіскував випуск Irodalmi Újság від 17 вересня 1955 року. Незважаючи на це, сотні примірників дійшли до читачів, і факт цензури став усім відомий [27].

Таким чином, Угорщина підійшла до 1956 року, в якому відбулася Народна революція, у підготовці якої, як видно з третього розділу, взяли активну участь засоби масової інформації країни. Звертає на себе увагу той факт, що угорські комуністи під керівництвом своїх московських однопартійців своїм недолугим втручанням у суспільно-політичне життя Угорщини наблизили народне повстання. I хоч з допомогою радянських танків вдалося Революцію задушити, цей перший у соціалістичному таборі паросток свободи розцвів у кінці 80- $\mathrm{x}$ - на початку 90-х років створенням демократичної, правової держави. 


\section{Література}

1. Большая советская энциклопедия. - М.: Советская энциклопедия, 1971. - Т.4.

2. Sibilla Haus. Hungary 1956. // Neue Arbeiterpresse. - 1996. 5.12 .

3. Венгрия. 1956 года. Очерки истории кризиса. - М.: Наука, 1993.

4. Мусатов В. Л. СССР и венгерские события 1956 г.: новые архивные материалы // Новая и новейшая история. - 1993. - № 1. - C. 9-17.

5. The 1956 Hungarian Revolution. A History in Documents. BP.: Institute for the History of the 1956 Hungarian Revolution, 2002. $-600 \mathrm{p}$.

6. 1946. évi I. Törvénycikk Magyarország államformájáról https:// net.jogtar.hu/ezer-ev- torveny?docid=94600001. TV\&searchUrl=/ezerev-torvenyei\%3Fpagenum\%3D42

7. Magyar Népakarat https://hu.wikipedia.org/wiki/N\%C3\%A9 pakarat_(napilap,_1945\%E2\%80\%931948)

8. A választójogi törvény reformja: Népakarat-átvitel https:// magyarnarancs.hu/belpol/a_valasztojogi_torveny_reformja_nepakaratatvitel-62404

9. Lőkös Zoltán - Péter László - Simon István: A Délmagyarország fél évszázada. 1910-1960. Jubileumi emlékkönyv. Szeged, 1960

10. Program és hivatás : magyar folyóiratok programcikkeinek válogatott gyüjteménye. Budapest. Gondolat Kiadó, 1978. Társadalmi Szemle (1931-1933 ; 1946-) lásd 549-560. p.

11. Török Bálint: Harmadik utas elképzelések. Magyar Szemle, 2009/11-12. 93-105.

12. Kertész Sándor: Comics szocialista álruhában (A magyar képregény ötven éve). NyHregyháza, Kertész Nyomda és Kiady, 2007.

13. Szerencsés i. m. (143. 1j.). A Hirlapszedők Ku̧re jelentése az 1944-1947-es esztendőkről. Felelős kiady: Benjamin Géza. й. n. 6-7. Pünkösti

14. Vásárhelyi Miklys: Ellenzékben. Budapest, Szabad Tér, 1989. 57, 65 .

15. Orgoványi István: A politikai rendőrség hályzati munkájának szabályozása 1954 és 1989 között. Betekintő, 2010/3. 2.

16. Norman Davies: Eurypa tụrténete. Budapest, Osiris, 2001. 472.

17. Hankiss Elemér: Diagnyzisok. Budapest, Magvető, 1982. 
18. Gelléri András: Mi legyen a cime? Magyar Sajty, 1955/5. 223-224.

19. Pokol Béla: Médiahatalom. áblogatott irások. Budapest, Windsor, 1995.

20. Rainer M. János (szerk.): A felügyelt (mozgás)tér. Tanulmányok a szovjet tipusú rendszer hazai történetéböl. Budapest, Akadémiai Kiadó, 2011. 281

21. Gomby Pál: Hrjunk határozottabban! Magyar Sajtó, 1956/1. $11-12$.

22. Nagy Imre beszédének a sajtyban való megjelentetéséről: Várkonyi i. m. (196. 1j.) 235-236.

23. Nagy Csaba: Lázadás a Szabad Népnél 40 évvel ezelőtt. Beszélgetés Lőcsei Pállal és Méray Tiborral. Kritika,1994/10. 10-11.

24. Idézi Kalmár Melinda: Az 1955-ós újságiró-ellenállás dokumentuma. Kritika, 1994/10. 8-9.

25. Irodalmi Újság, 1953. augusztus 18.

26. Földes Anna: Az Irodalmi Újság könyve. Tanulmányok, portrék és dokumentumok, mellékletben az 1956.november 2-i szám facsimilǔje. Budapest, új KÉZirat, 2001. 31.

27. Rainer M. János: Az iró helye. Viták az irodalmi sajtóban 19531956. Budapest, Magvető, 1990. 124. 


\section{4. Журналістика Угорщини під час революції 1956 року}

У середині жовтня 1956 р. внутрішньополітична ситуація в Угорщині різко погіршилася. Небезпека полягала в тому, що коли 3-4 місяці тому невдоволення висловлювала тільки інтелігенція, то тепер ці настрої починали досить широко проникати в середовище робітників, не кажучи вже про селянство, що «помітно схвильоване і вимагає розпуску виробничих кооперативів». Окрім того, «критичні настрої почали поширюватися серед частини працівників держбезпеки і деяких керівних армійських працівників», які виступали «проти керівництва партії» [1, с. 265].

Ускладнення становища в країні зумовлювалося і труднощами в економіці: зібраний того року врожай був значно менший за попередній; через нестачу в країні вугілля, нафти й сировини простоювали підприємства; на залізничному транспорті було скорочено 600 потягів, головним чином пасажирських. Усе це торкалося інтересів угорців і впливало на їхні настрої [2].

На осінь 1956 р. невдоволення «комуністичним» режимом стало загальним. Робітники, студенти, представники інтелігенції вимагали свободи слова, друку та зборів, рівноправних відносин із СРСР, скасування принизливої системи зарплати, нормування праці на підприємствах, робітничого самоврядування й студентської автономії.

Утім, слід зазначити, що багато робітників пам'ятали капіталізм і не хотіли його повернення. Загальний настрій угорських робітників можна сформулювати так: «ні» капіталізмові та «ні» бюрократичному псевдосоціалізмові, «так» соціалізмові, що базується на самоврядуванні». Після антиурядової демонстрації 
23 жовтня 1956 р. у Будапешт було введено радянські війська. У місті розпочалися бої між радянськими танками, силами угорської держбезпеки, з одного боку, й угорськими трудящими - 3 другого. На вулицях міста з'явилися барикади, створювалися квартальні революційні комітети, які допомагали повстанцям продовольством і піклувалися про поранених. Частина солдатів Червоної Армії відмовилася стріляти в робітників, за що деякі 3 них були страчені радянською держбезпекою. До 25 жовтня майже на всіх заводах та фабриках Будапешта були сформовані робочі ради, що фактично взяли ці підприємства під свій контроль. На кілька днів радянські війська залишили місто. Однак уже 4 листопада вони повернулися в столицю Угорщини і сформували уряд на чолі з Я. Кадаром.

21 листопада в Будапешті було скликано всеугорські збори 3 метою утворення національної робочої ради. Коли робітники прибули на місце їх проведення, поліція й армія перекрили входи в будинок. Незважаючи на погрози, делегати перебралися в інше місце і таки провели збори.

Тільки після кількох тижнів репресій урядові Кадара вдалося встановити свою владу над радами. Не маючи незалежного політичного керівництва, робочі ради не змогли захопити владу в країні. Натомість вони вели нескінченні переговори з урядом Кадара. Зрештою більшість рад прийняла рішення про припинення страйку. Але на цей заклик відгукнулася лише чверть усіх робітників.

На початку 1957 р. уряд Кадара видав декрет, який забороняв страйки і заклики до них, погрожуючи організаторам стратою. Робочим радам було заборонено приймати будь-які політичні рішення, й усі резолюції, що стосуються внутрішнього життя заводів та фабрик, мали дістати схвалення політичного комісара - партійного секретаря.

Здійснення силових акцій впливу на угорське суспільство заради збереження оголошеного «єдино справжнього взірця» соціалізму, недопущення будь-якого відходу від нього спричинило чимало жертв і призвело до безлічі людських трагедій. У боях з 23 жовтня і до січня 1957 р. (коли ще продовжувалися каральні операції) загинуло понад 2,5 тисячі угорців, кількість 
поранених перевищувала 19 тисяч. 3 радянського боку прямих жертв серед військових було 720 чоловік, поранено та травмовано - 2260 [3, с. 339].

Цим практично і закінчується історія угорської революції 1956 р. Трудящі Угорщини ще раз довели, що свободу можна здобути тільки в боротьбі й що вона ніколи не буде подарована згори. Країна знов опинилася під комуністичним контролем, а на чолі партії й уряду став ставленик Кремля Я. Кадар, який, щоправда, пішов шляхом повільної лібералізації місцевого соціалістичного режиму. І. Надь, який утік в югославське посольство, був виданий новій угорській владі, а по суті - СРСР.

Окремо потрібно сказати про пресу Угорщини під час Революції 1956 року. Як і будь-яке неординарне історичне явище, угорська революція породила яскраву публіцистику, що прекрасно передає духовну атмосферу «будапештської осені», сповнену одночасно пафосу і трагізму [4]. Разом з тим, досвід функціонування друкованих видань та радіо в Угорщині 1956 року цікавий і в іншому плані - він дає поживу для роздумів про роль засобів масової інформації в умовах кризи політичної системи, свідомо не допускає плюралізму й, тим самим, виключає адекватне вираження інтересів окремих соціальних груп.

Не парламентська трибуна та інші представницькі органи, що формуються, як правило, зі ставлеників влади, а в більшій мірі саме преса здатна виступити в якості справжнього рупора суспільних настроїв. Саме 3МI, навіть у кризовій ситуації, зберігають контроль над друкованим словом і спроможність пробити проломи в стіні тотально насаджуваної однодумності. Будучи найбільш мобільними, чутливими до змін духовного клімату в суспільстві, преса і радіо, телебачення, реагуючи на громадську думку та, в свою чергу, формуючи їі, зберігають певну здатність впливати на події не тільки при прихованому перебігу кризи, але, до певної міри, і в умовах мітингової стихії, коли невдоволення мас проривається на вулицю. У зв'язку з цим постає питання про роль професійного журналістського співтовариства як одного з невід'ємних інституційних елементів будь-якого суспільно-політичного простору в новітній час. 
У третьому розділі детально проаналізовано, яку роль зіграла угорська преса у підготовці Революції 1956 року. Продовжуючи цю тему, повернемося до осені 1955 року, коли саме журналістські, а також літературні спільноти були особливо активні у виробленні та відстоюванні альтернативних політичних проєктів. Листи з вимогою реформ, меморандуми протесту й інші акції, висловлюючи широке громадське невдоволення, заповнювали простір - політичний вакуум, який утворився при відсутності легальної опозиції [5]. Цілком зрозуміло, що головний удар контрреформаторськи налаштованої влади був спрямований саме проти цієї категорії інтелігенції. Апофеозом антиреформаторського курсу стало прийняття наприкінці 1955 року партійної постанови «Про праві явища в літературному житті». Група журналістів, письменників, діячів мистецтв, які підписали меморандум протесту проти низки конкретних адміністративних заходів культурної політики - вилучення одного 3 номерів тижневика «Irodalmi Újság», заборона театральної постановки і т.ін. - була звинувачена в підриві керівної ролі партії.

Важливим рупором, де формувалася в післяз'їдівській атмосфері опозиція (в той час поки ще майже виключно внутрішньопартійна), продовжував залишатися тижневик Спілки письменників «Irodalmi Újság». Драматург і критик Д. Хай 5 травня зазначав на сторінках цього видання, що наслідки культу особи зачепили всі сфери життя: «прийняті без заперечення неправильні й шкідливі резолюції, бездумна свавільність, великі та малі збори, які всьому піддакують, переслідування за критику, лакування і демагогія, ... нехтування законів та прав», - все це стало в попередні роки в Угорщині буденним явищем, обтяжуючи повсякденне існування мільйонів громадян. ХХ з'їзд КПРС був названий в статті «великим тріумфом людської гідності», вплив якого не може обійти стороною Угорщину.

Стаття Д. Хая викликала різку відповідь публіцистів охоронно-сталінського табору і захоплені відгуки прихильників реформ. Публікації, подібні до неї, привертали увагу все більш широкої публіки, вони обговорювалися на партзборах, імена письменників та публіцистів, які відстоювали реформаторські погляди, ставали популярними в середовищі інтелігенції. 
Антидогматичний пафос деяких публіцистичних виступів поєднувався з прагненням їх авторів покінчити 3 власним минулим.

П. Панді, один з провідних журналістів «Szabad Nép», своїми нарисами про СРСР, доброзичливими і в той же час такими, що не ідеалізували радянську дійсність, намагався зруйнувати сформований в угорській пресі за роки комуністичного правління стереотип зображення «країни Рад» у рожевому світлі, що відштовхувало читача своєю явною неправдоподібністю [6].

Навіть посол Радянського Союзу Ю.В. Андропов, який з великою пересторогою ставився до будь-яких спроб дистанціюватися від радянського досвіду, не міг не визнати «наявну раніше практику надмірного захвалювання радянської дійсності». 3 іншого боку, образ СРСР у нарисах Панді сильно розходиться зі звичними пропагандистськими кліше, давав підстави писати в дипломатичних донесеннях про паплюження і випинання недоліків. ХХ з'їзд КПРС узагалі дещо підвищив інтерес читацької аудиторії до сприйняття радянської тематики, яка вже давно втратила свіжість.

На сторінках низки видань, включаючи «Szabad Nép», ставиться питання про співвідношення в соціалістичній економіці планового і ринкового початків, дії закону вартості, необхідності активізувати товарно-грошові відносини. Хоча І. Надь продовжував перебувати в опалі, багато положень його економічної програми 1953-1955 років були знову затребувані в ході дискусій.

24 червня «Szabad Nép» виступила 3 позитивною оцінкою Гуртка Петефі, назвавши його «світочем справжнього марксизму». Ю.В. Андропов, котрий у діяльності Гуртка насамперед бачив загрозу політичній монополії УТП, доповідав у Москву, що редактор газети М. Хорват проявляє коливання, «втрачає правильний курс у низці питань, впадає в паніку, надає сторінки партійної газети для опублікування статей, в яких нерідко протягуються чужі партійні погляди» [7]. Схожа характеристика міститься і в іншому документі - огляді виступів угорської преси про Гурток Петефі, підготовленому майбутнім очільником КДБ та членом Політбюро ЦК КПРС В. А. Крючковим, 
у той час займав скромну посаду третього секретаря посольства СРСР в Угорщині [8]. На думку Крючкова, угорська преса «допускала невиправдані вихваляння» діяльності гуртка і, тим самим, створювала грунт для антипартійних виступів, «збивала $з$ пантелику багатьох чесних товаришів». Це пояснювалося тим, що Центральне Керівництво УТП «не оцінило належним чином роботу преси, не здійснювало необхідного контролю за нею».

Аналогічним чином розцінювалася і лінія найстарішої в Угорщині профспілкової газети «Népszava» (до 1948 року орган самостійної соціал-демократичної партії). Коментуючи 24 червня одну з дискусій на Гуртку Петефі, в ході якої прозвучала вимога повної реабілітації й урочистого перепоховання Л. Райка та інших репресованих режимом Ракоші діячів угорського робочого руху, «Népszava» закликала помістити світлини цих людей у «пантеон національних героїв» Угорщини.

24 червня «Szabad Nép» поінформувала читачів про майбутні дискусії Гуртка Петефі з актуальних проблем друку і масової інформації. Ця дискусія, яка тривала протягом дев'яти годин вечора 27 червня, перевершила всі попередні не тільки за напруженням пристрастей, а й за кількістю учасників: понад 6000 осіб заполонили не тільки зал будапештського Будинку офіцерів, а й прилеглі двори, слухаючи емоційні промови доповідачів через гучномовці.

Відновив критику ретроградних сил в УТП літературний тижневик «Irodalmi Újsag», який за лічені тижні збільшив тираж 38 до 30 тис. примірників. Значний резонанс викликали також публікації в газетах «Esti Budapest», «Magyar Nemzet», «Szabad Ifjúság», «Hetfői hirláp». До розриву зі старими методами, відмови від сталінської політичної практики все частіше закликав і центральний партійний друкований орган «Szabad Nép». Вважаючи відставку Ракоші лише першим кроком у процесі змін, реформаторски налаштовані публіцисти добре усвідомлювали, що кадрові зміни на вершині піраміди влади, як і деякі послаблення інтелігенції, спрямовані насамперед на нейтралізацію опозиції, що тільки формується і носить тактичний, а не принциповий характер. Головним гальмом на шляху онов- 
лення їм видавалися вже не окремі особи, а вся система, що не відповідала їх уявленням про справжній соціалізм.

Проблему свободи друку торкнувся 8 вересня на сторінках «Irodalmi Újság» Д. Хай. Для літераторів, зазначав він, «не повинно бути заборон ні в чому, крім того, що заборонено законом для всього суспільства ... I, навпаки, письменнику, як і всім смертним, має бути дозволено без обмежень говорити правду; критикувати всіх і вся ... вірити в Бога, не вірити в нього; сумніватися в правильності планових показників; думати не помарксистському, ... вважати несправедливим те, що офіційно, можливо, вважається справедливим; не любити окремих керівників; зображати недоліки, не пропонуючи при цьому рецептів їх усунення, ... використовувати незвичний стиль, ... називати нікчемними твори, які деякими авторитетами видаються за зразкові; висловлювати певні літературні думки, чхати на певні літературні думки, і т.д., і т.п ... Ось свобода, за яку нам, письменникам, потрібно стояти до кінця». У статті відкрито порушувалося питання про протиприродність існування в демократичному суспільстві установ, спеціально створених для контролю за думкою.

Ця теза була сприйнята у вересні 1956 року партійним керівництвом як єретична, разом з тим, у певній мірі автор передбачив культурну політику кадаровского режиму в період його розквіту. Г. Лошонци 2 вересня в газеті «Müvelt Nép» не тільки квапив 3 прийняттям конкретних рішень, спрямованих на поліпшення становища мас, але закликав зробити висновки щодо осіб, які своїм «сектантським засліпленням, нетерпінням і впертою нелюдськістю нанесли людям рани, які погано гояться, але, незважаючи на це, продовжують перебувати на керівних постах». У пресі ставиться питання і про необхідність притягнення до відповідальності Ракоші за всі гріхи, вчинені ним перед народом, незабаром після липневого пленуму він виїхав до СРСР.

Усе наполегливіше звучала в пресі й вимога про відновлення справедливості щодо Імре Надя. У «Листі Чепельського робітника», опублікованому в «Irodalmi Újság» 13 жовтня, його «новий курс», проголошений у 1953 році, був названий «оазисом у пустелі божевільної сталінської політики», тоді як «до 
хрускоту зіщуливши кістки», березнева постанова 1955 року про відсторонення І. Надя, як зазначалося, «зруйнувала слабкі пагони віри в демократичний дух».

У середині жовтня з давно вже небаченою гостротою ставилися в пресі проблеми матеріального становища трудящих. «На кошти, зекономлені недоїданням робочих», утримуються численні державні установи, «які не роблять абсолютно нічого корисного», говорилося в одній зі статей. Андропов, побачивши в цій публікації «прямий заклик до вираження невдоволення», назвав тон подібних статей «явно загрозливим», а методи написання «провокаційними» [9].

До цього часу прихильники І.Надя, які відстоювали концепцію національного угорського і при цьому більш демократичного шляху до соціалізму, контролювали вже значну частину засобів масової інформації.

Інституціоналізація реформаторськи налаштованої частини журналістської спільноти (точніше, ії еліти) в свого роду альтернативний центр влади стає до середини жовтня 1956 року вже не перспективою, а втіленою реальністю. Так, у самий переддень повстання 23 жовтня молодий член Політбюро Л. Ач, якому доручили керувати партапаратом на час поїздки Е. Герьо та очолюваної ним делегації в Белград, скаржився Андропову, що для публікації в центральному органі партії низки матеріалів він був змушений звертатися за «дозволом» до журналістів 3 оточення Надя, а саме Ш. Харасті й Г. Лошонци, які не займали важливих посад у партійній номенклатурі, але мали величезний неформальний вплив.

Редактор «Szabad Nép», колишній член Політбюро М. Хорват, за повідомленнями радянського посольства, також внутрішньо співчував I. Надю, а рішення партійного керівництва якщо і намагався виконувати, то тільки в силу властивого старому партійцю почуття дисципліни.

Усупереч протидії Політбюро ЦК КПРС, редакції центральних газет і Спілка угорських журналістів висловили солідарність польській «Trybuna Ludu», яка в ті дні вступила у відкриту полеміку з «Правдою», що виступила з критикою деяких статей польської преси. «Szabad Nép» була єдиною центральною пар- 
тійною газетою однієї з країн радянського блоку, яка вранці 23 жовтня повністю опублікувала програмну промову В. Гомулки на VIII пленумі ЦК ПОРП. «Правда» вирішила повністю їі не публікувати (на тій підставі, що це зробило б необхідним коментарі й призвело б до небажаних суперечок).

Фактом втручання СРСР у внутрішні справи Польщі стало прибуття до Варшави без запрошення делегації КПРС на чолі 3 самим Н.С. Хрущовим для спроби 19 жовтня перешкодити наміченим кадровим перестановкам на пленумі ЦК ПОРП, про що відверто повідомляло угорське радіо [10].

Якщо в Польщі комуністична еліта, зробивши рішучий поворот до відстоювання національних пріоритетів перед диктатом Москви, зуміла розрядити вибухонебезпечну обстановку, то в Угорщині постійне запізнення влади з прийняттям ефективних заходів призвело врешті-решт до збройної конфронтації. Започаткована в знак солідарності з польськими подіями студентська демонстрація 23 жовтня не змогла втриматися в рамках мирної мітингової акції, переросла в потужне народне повстання. Введення радянських військ в Будапешт у ніч на 24 жовтня в цілях залякування не тільки підлило масла у вогонь, але надало повстанню чітко виражений національний характер. По всій Угорщині відбувається розпад колишніх партійно-державних структур, влада починає переходити до стихійно сформованих революційних комітетів і робочих рад [11].

Цензура йде в минуле, країна вступає в 12-денний період абсолютної свободи преси [12].

Програма безпосередніх організаторів масової демонстрації, призначеної на вівторок 23 жовтня (студентів Будапештського політехнічного інституту), помітно перевершувала своїм радикалізмом вимоги, що звучали в ході дискусій Гуртка Петефі, інших виступів опозиції в попередні місяці. Окрилені успіхом польських реформаторів, які домоглися принципових поступок від Москви (зміни партійного керівництва, ліквідації інституту радників у силових структурах), їх угорські однодумці тепер наполягали на негайному виведенні з Угорщини радянських військ, дозволу діяльності політичним партіям, проведенні таємних виборів у Державні збори на альтернатив- 
ній основі, перевибори всіх керівних органів УТП, суд над М. Ракоші. Серед іншого в списках студентських вимог значилися: скасування цензури, здійснення свободи друку, створення незалежної щоденної газети як органу, утвореного в переддень революції Угорської спілки студентів, непідконтрольної УТП та Спілці трудящої молоді. Оскільки в центральній пресі до цього часу, як уже зазначалося, тон задавали представники реформаторського крила партії, які симпатизували студентам, програму з 16 пунктів вдалося опублікувати або хоча б в загальних рисах викласти в низці газет, зробивши їі, таким чином, надбанням найширшої громадської думки, правда, цензура поки що зуміла перешкодити іiі оприлюдненню на радіо.

3 плином часу демонстрація набувала дедалі більшого розмаху, змінювався склад ії учасників: після закінчення трудового дня в ряди демонстрантів влилися службовці державних установ, розташованих у центрі угорської столиці, з промислових околиць міста в його центральні райони стікалися заводські робочі. «Вулиця - наша!» - цей яскравий заголовок передової статті центральної молодіжної газети «Szabad Ifjúság», що вийшла спеціальним випуском до вечора 23 жовтня, досить точно передавав настрій багатотисячних мас. У статті йшлося про те, що вихід студентів на вулицю ставить собі за мету не тільки вираз солідарності з поляками. Угорська молодь і весь народ прагнуть до очищення власної партії від сталінської спадщини, повного розгортання соціалістичної демократії.

Передова стаття «Szabad Nép» у цей день також називалася симптоматично: «Новий весняний огляд рядів». «Спекотна атмосфера на молодіжних зборах останніх днів, - писала газета, - схожа швидше «на весняний розлив, ніж на перебіг вод, спрямованих в штучні канали». Газета вітала молодь, яка виступає за «чистоту соціалізму», висловила солідарність з багатьма конкретними вимогами організаторів демонстрації і, в тому числі, про звільнення від тих людей у партійному керівництві, які «не можуть або не хочуть послідовно рухатися по шляху, наміченому XX з'їздом». У той же час газета застерегла учасників маніфестації від потурання по відношенню до антисоціалістичної пропаганди в своїх рядах. Уже в перші години демонстрації її 
масштаби далеко перевершили очікування внутрішньопартійної демократичної опозиції, в тому числі впливових людей 3 журналістської спільноти (Г. Лошонци й ін.), які марно намагалися направити хід в організоване русло.

О восьмій годині вечора на радіо пролунав виступ Е. Герьо, що рясніло різкими випадами на адресу організаторів демонстрації й викликало гнівну реакцію багатотисячного натовпу, який зібрався перед будівлею парламенту. У подальших подіях проявилася закономірність багатьох революцій в їх початковій стадії - стихійне прагнення мітингувальників до оволодіння засобами масової комунікації. Спроба молоді проникнути в будівлю радіо з тим, щоб зачитати свої програмні вимоги, призвела до зіткнення з частинами держбезпеки, з'явилися перші вбиті та поранені. Мирна спочатку акція набуває іншу якість, формуються перші повстанські групи. Крайню розгубленість у критичній обстановці не тільки влади, а й загалом реформаторски налаштованої журналістської спільноти відбила тональність мовлення радіо. «Угорське радіо, яке працює з підвальних приміщень парламенту, щогодини «забороняє революцію». Воно просить, благає, лестить, пускається в пояснення, загрожує, зваблює, попереджає: одумайтеся, мовляв, а то в неділю не відбудеться футбольний матч. Але до цього часу бруківка вже обагрена кров'ю 250 людей», - згадував згодом активний учасник подій, публіцист і перекладач Арпад Гьонц, у 1990-2000 роках Президент Угорської Республіки [13].

Вступ радянських танків у Будапешт відбувся до ранку 24 жовтня відповідно до прийнятого пізно ввечері рішення Президії ЦК КПРС [14]. Він ставив собі за мету демонстрацію військової сили, солдати не отримали наказу про застосування вогню. Проте ця акція викликала сплеск патріотичних настроїв і дала багатьом сотням людей підставу виступити зі зброєю в руках на захист національного суверенітету Угорщини.

Преса тих днів стала хронікою подій, що відбувалися. 24 жовтня в місті не вийшла жодна газета, тиражувалися лише повстанські листівки з вимогою вже не тільки негайного виведення радянських військ, але і виходу з Варшавського договору, а також включення представників «революційної молоді» в уряд. 
25 жовтня 3 центральних газет вийшла лише профспілкова «Népszava», від імені Угорської ради профспілок вона зажадала припинення вогню з обох сторін і амністії всім, хто складе зброю. У той же день був опублікований перший номер «газети угорської революційної молоді» «Igazság» під редакцією комуніста Д. Обершовського, що відображала самооцінку поміркованого крила учасників збройного опору і поклала початок вільної, безцензурної преси угорської революції. «Повсталий народ, - зазначають у газеті, - як уже не раз бувало в історії, коли переповнюється чаша терпіння, бере в свої власні руки вирішення долі... Від імені всіх угорців ми протестуємо проти того, щоб священна боротьба революційного народу характеризувалася як фашистське зборище (таке визначення звучало в деяких заявах на радіо від імені влади, хоча вже починаючи з 24 жовтня загалом домінували більш стримані оцінки). Відбулася революція. Народ протестував не проти ладу, не проти соціалістичних ідей, а проти тих, хто забруднив та спаплюжив ці ідеї. Народ хоче соціалізму, але чистого и чесного» [15].

Аналогічне за змістом та пафосом Звернення учасників боротьби було опубліковано 26 жовтня на сторінках «Magyar Nemzet», органу Вітчизняного народного фронту: «Ми не контрреволюціонери та не фашисти. Боротьба, яку ми ведемо, висловлює основні бажання угорських мас... Ми хочемо не тільки ясності та порядку, але світла вільної країни» [16].

Газета «Szabad Nép» 26 жовтня відображала думку того крила партійного керівництва, яка прагнула компромісу з повстанцями. Засудили Гьоре і його команду за нездатність вивести країну з кризи та закликали повстанців до припинення вогню, а населення до спокою, висловилися за пошуки власного, угорського шляху до соціалізму.

Імре Надь, за рішенням Політбюро, вранці 24 жовтня знову очолив Раду Міністрів, спочатку не протестував проти участі Радянських військ у «наведенні порядку». Але з перших днів в оточенні Прем'єра, яке він залучив до керівництва країною із табору своїх прихильників, усе голосніше лунають голоси з вимогою не тільки більш рішучого відмежування від колишньої політики, що похитнула віру народу «в сам зміст будівництва соціалізму», а й 
перегляду ставлення до збройних повстанців. Соратник I.Надя журналіст Г. Лошонци й економіст Ф. Донат, кооптовані 24 жовтня в вищі органи партії, в той же день на знак незгоди $з$ оцінкою характеру подій, що відбуваються, заявляють про вихід із ЦК УТП.

Також належали до команди I. Надя журналісти М. Гімеш и М. Вашархейі вступають у прямий контакт з видавцями повстанських листівок. 3 перебігом часу, як відомо, змінилася й позиція самого прем'єр-міністра, в свідомості якого, як і багатьох його соратників по партії, угорський патріотизм переважив глибокі комуністичні переконання. Оскільки введення радянських військ практично збіглося за часом 3 призначенням I. Надя главою уряду, заява на радіо про звернення за військовою допомогою до СРСР була зроблена нібито і від імені нового прем'єр-міністра. Це не могло не позначитися на падінні народної довіри до уряду й особисто Імре Надя. Про його «зраду» не тільки писали в листівках, але навіть говорили незалежні радіостанції, які виникли в ці дні.

Поступово, усвідомивши неможливість нормалізації за допомогою сторонньої військової сили і відчувши, що широкі маси відмовляють у підтримці нового уряду, I. Надь 28 жовтня зробив рішучий крок до зближення з повстанцями, визнавши законність багатьох їхніх вимог, у тому числі про виведення радянських військ з території країни [17].

Для того щоб повною мірою оцінити поворот в позиції прем'єр-міністра, досить зіставити два його виступи на радіо, між якими лежали всього три дні. Якщо 25 жовтня Надь говорив про те, що «жменька підбурювачів-контрреволюціонерів зробила збройний виступ проти нашої народної республіки, який підтримала частина трудящих Будапешта, доведених до відчаю становищем у країні», то в його виступі від 28 жовтня звучали вже зовсім інші ноти: «уряд засуджує погляди, відповідно до яких нинішній грандіозний народний рух розглядається як контрреволюція ... цей рух поставив собі за мету забезпечити нашу національну незалежність, самостійність і суверенітет, розгорнути процес демократизації нашого суспільного, економічного, політичного життя, оскільки тільки це може бути основою соціалізму в нашій країні». 
У цей день «Szabad Nép» 3 відома і згоди прем’єр-міністра I. Надя та нового першого секретаря ЦК УТП Я. Кадара опублікувала статтю «Відповідно до істини». «Ми не згодні з тими, хто події минулих днів огульно кваліфікує як спробу контрреволюційного, фашистського путчу... Величезну патріотичну демонстрацію заплямували кров'ю, що стало початком найстрашнішої братовбивчої боротьби». На думку газети, всю Угорщину охопив національний демократичний рух, очолити його було б честю для партії. Головну рушійну силу становлять не зловмисні елементи 3 колишніх експлуататорських класів, які також вийшли на поверхню, а молодь робітничо-селянського походження, віддана ідеї побудови соціалізму, але відповідно до угорських умов. Опорою уряду і партії, що оновлюється, повинні стати утворювані по всій країні самодіяльні народні органи, «викликані до життя міцніючим духом демократизму».

Профспілкова «Népszava» 28 жовтня також дійшла висновку про те, що, незважаючи на присутність антисоціалістичних елементів, «чесний рух нашої молоді не став контрреволюційним повстанням».

Зміна оцінки подій, що відбуваються, спонукала газету «Szabad Nép» вступити в полеміку з «Правдою», яка опублікувала 28 жовтня статтю свого власкора «Крах антинародної авантюри в Угорщині» [18]. Стаття була опублікована без вказівки прізвища власного кореспондента. Ймовірно, iї автором був працюючий у цей час власкором у Будапешті С. Крушинський. Як зазначалося в статті, «антинародна авантюра» в Угорщині «стала результатом тривалої підривної роботи, що проводиться імперіалістичними державами, які не відмовилися від злочинного наміру зруйнувати народно-демократичні держави, відновити в них капіталістичні порядки». За допомогою ззовні в країні було створено «контрреволюційне підпілля, добре озброєне і ретельно підготовлене до активних дій проти народного ладу». Путчисти нібито діяли заздалегідь продуманим планом, підшукували гарну нагоду для виступу, активну роль у керівництві ними зіграли досвідчені у військовому відношенні люди хортистські офіцери. У статті визнавалося, що наявні в країні труднощі, невирішені завдання, «серйозні помилки», порушен- 
ня законності зробили частину населення сприйнятливою до контрреволюційних закликів, що допомогло ворогам залучити до своєї «авантюри» трудящих. Це, однак, на думку газети, ні в якій мірі не змінювало принципової оцінки подій як «контрреволюційного путчу».

Відповідь «Правді», написана журналістом газети М. Мольнар, була опублікована 29 жовтня. «Те, що відбулося в Будапешті, - писала головна газета УТП, - не було ні антинародним, ні авантюрою і не зазнало краху». В подіях останніх днів домінували гасла соціалістичної демократії. «Революційний народ Пешта і Буди хоче свободи, життя без свавілля, терору і страху, більше хліба і національної незалежності. Хіба це «антинародна авантюра» ?! Те, що повалено, те, що дійсно може бути названо антинародним, - це панування кліки Ракоші - Гьоре». Газета відкинула заяву «Правди» про вирішальну роль у подіях західних імперіалістів, «які не шкодують зусиль для втручання в справи соціалістичних країн шляхом провокацій, диверсій, організації контрреволюційного підпілля». «Це твердження «Правди» принижує й ображає все півторамільйонне населення Будапешта», значна частина якого висловлювала співчуття основним патріотичним і демократичним цілям «великого народного виступу» за угорський шлях до соціалізму, національний суверенітет і побудову відносин з СРСР на рівноправній основі.

Починаючи 328 жовтня, було оголошено про повсюдне припинення вогню, скасування Управління державної безпеки, формування нових органів правоохорони із залученням повстанців. Уряд санкціонував створення Революційного комітету оборони на чолі з генералом Б. Кіра. Цей комітет зробив спробу підпорядкувати розрізнені повстанські групи єдиному командуванню. За погодженням з Москвою, радянські танки і військові частини в кінці жовтня виходять з Будапешта. Із задоволенням узяв до відома цей факт «Szabad Nép», у статті під показовим заголовком «Світає» констатував перемогу народного руху. Молодіжна «Szabad Ifjúság» закликала повстанців покласти край збройній боротьбі, оскільки першочергова мета була досягнута. 3 цього часу на сторінках найрізноманітніших видань усе 
більше місце займають проблеми налагодження мирного життя, подолання розрухи.

Утім, декларований І. Надьом поворот в оцінці подій і ставлення до повстанців аж ніяк не означав, що уряд відтепер користувався загальною довірою. Один з радикальних повстанських лідерів, глава самопроголошеного «угорського національного революційного комітету» Й. Дудаш, будучи прийнятим I. Надьом 30 жовтня, в той же день випустив номер своєї щойно утвореної газети «Függetlenség» 3 великим заголовком на першій шпальті: «Ми не визнаємо нинішній уряд».

28 жовтня і в наступні дні поширювалися листівки як із закликами продовжувати страйк до повного виведення радянських військ з території країни й проведення вільних виборів, так і з пропозиціями приступити до роботи, надати підтримку I. Надю та його команді. Якщо центральне радіо намагалося створити враження поступового відновлення порядку в країні, то на хвилях радіостанцій Дєра і Мишкольца, що знаходилися в руках місцевих революційних комітетів, відбувалася ескалація нових політичних вимог.

У кінці жовтня стихійно активізувався процес відродження лівих і центристських партій, які діяли на політичній арені Угорщини до встановлення комуністичної диктатури в 1948 році. Їх програмні заяви, як правило, вказували на необхідність збереження базових галузей промисловості й фінансів у руках держави. Уряд у перші дні листопада реорганізується вже на коаліційній основі. Кожна з утворених партій починає видавати власні газети, причому в низці випадків поновлювалися раніше закриті видання. Серед виниклих в останні дні жовтня, як гриби після дощу, газет деякі проголошували себе рупорами тих чи тих політичних сил, інші декларували свою незалежність [19].

Виявилися затребуваними старі професійні кадри, витіснені після 1948 року з преси або відтіснені на глибоку периферію засобів масової інформації. Журналістська спільнота Угорщини, в якій протягом попередніх кількох місяців існували лише два протиборчі крила- охоронно-сталінське і реформ-комуністичне - починає реорганізовуватися на справді плюралістичній основі. При всіх відмінностях у підходах та ідеологіях існувала і за- 
гальна для всіх виниклих видань платформа - вимога суверенітету Угорщини. «Наша газета прагне служити справі угорської свободи. І зовнішньої свободи - незалежності, і внутрішньої свободи - демократії. Служити дієво, висловлюючи всю правду і чисту правду», - так визначила свої завдання газета« Magyar Szabadság» у першому номері, що вийшов 30 жовтня.

1 листопада та ж газета опублікувала статтю під характерним заголовком «Незалежна Угорщина повинна стати нейтральною». У ній проводилася думка про Угорщину як про міст між Заходом і Сходом. Коли на початку листопада до порядку денного угорської політики була висунута ідея нейтралітету країни, вона була підтримана всіма газетами, при цьому зазначалося, що незалежна зовнішня політика, без якої «немає здорового розвитку нації», аж ніяк не передбачає недружню позицію щодо «нашого могутнього сусіда»- СРСР і «товаришів по історичній долі» - східноєвропейських народів.

Про необхідність розбити залізну завісу, встановити більш тісні економічні зв’ язки із Заходом писала газета «Magyar Világ». «Népszava», знову ставши органом соціал-демократичної партії, висвітлювала роботу засідання бюро Соцінтерну у Відні, де обговорювалося питання про перспективи підключення до економічного відродження Угорщини структур Свропейського Економічного Співтовариства, ідея створення якого вже витала в повітрі, а конкретні плани пророблялися. Загальною для публікацій найрізноманітніших газет була революційна патетика 3 незмінним озиранням на світову громадську думку: ми «пишемо всесвітню історію»; ми «мала, але героїчна нація, перед якою всі народи світу приспускають прапори на знак пошани i поваги» (потреба в національній гордості була тим більш сильна, що в пам'яті багатьох людей ще живі були нотки самознищення офіційної комуністичної пропаганди, яка періодично нагадувала угорцям про ганебну роль їх країни в роки Другої світової війни як останнього, найбільш вірного сателіта нацистської Німеччини). Революційна фразеологія певною мірою відрізняла навіть католицьку газету «Új ember».

Найбільш відомі публіцисти угорської революційної преси, включаючи редактора газети «Magyar Szabadság» M. Гіме- 
ша, принципово стояли на платформі соціалізму, виступали за 3'єднання багатопартійності та західної «техніки свободи» (за висловом міністра в уряді І. Надя європейського відомого політолога І. Бібо) з визнанням націоналізації великої власності й вимогою забезпечення загального права на працю та освіту. Зверталася увага на небезпеку різкого повороту вправо, присутність у широкому народному русі регресивних і деструктивних сил, які «плямують брудом чистоту нашої боротьби» й можуть позбавити угорську революцію симпатій світової громадської думки і підвищити небезпеку нового іноземного втручання. Побудова незалежної й демократичної Угорщини, на думку М. Гімеша, неможлива без боротьби як проти всіх пережитків колишньої політики, так і проти «всіляких проявів контрреволюції».

Про посилення небезпеки хаосу свідчили багато фактів, i насамперед сумно відомий кривавий інцидент 30 жовтня перед будівлею будапештського міськкому, жертвами якого стали більше 20 осіб. Він отримав, до речі, одностайне засудження всієї преси, включаючи найрадикальніші видання, і дійсно вказав світовій громадській думці, що симпатизувала угорським повстанцям, на реальну небезпеку розгулу насильства, анархії й охлократії в разі нездатності уряду стримати різкий зсув політичного життя вправо. 29 жовтня відбулося захоплення повстанцями групи Й. Дудаша будівлі газети «Szabad Nép». Цей факт добре описав у своєму «Угорському щоденнику» очевидець революції, відомий польський публіцист і поет В. Ворошільський: озброєні люди «з'явилися в редакцію і стукнули кулаком по столу: «Досить годувати народ брехнею і лайкою». Редактори обурено заявили, що не стануть розмовляти з хуліганами, і покинули приміщення. «Szabad Nép» перестала існувати» [20].

Майже одночасно з ліквідацією свого друкованого органу припинила існування та саморозпустилася УТП. В умовах формування багатопартійності група її видатних діячів і ветеранів комуністичного руху, включаючи І. Надя, Я. Кадара, всесвітньо відомого філософа Д. Лукача, виступила ініціаторами створення нової партії - Угорської соціалістичної робочої (УСРП), що проголосила програму будівництва соціалізму на основі повно- 
го розриву зі сталінською спадщиною. 1 листопада партія почала видавати газету «Népszabadsag», протягом усієї подальшої кадаровської епохи стала головною газетою країни. Газет з дня на день стає все більше, майже всі вони редагуються і друкуються в будівлі колишньої «Szabad Nép», захопленої групою Дудаша. Дудаш лояльний: свою газету видає й іншим не заважає. До лав газет, які друкуються під крилом Дудаша, додалася комуністична «Népszabadság». Ï̈̈ роблять колишні журналісти «Szabad Nép», у різний час звільнені з редакції і які зазнали політичних переслідувань [21].

Треба зауважити також, що група видних журналістів центральної преси (М. Гімеш та ін.) дистанціювалася від УСРП і, відмежувавшись разом з тим від традиційної соціал-демократії, заявила про створення соціалістичної партії. Вони стали видавати газету «Magyar Szabadság» і проголосили, що всі партії мають право на свободу, крім тих, які хочуть монополізувати істину та придушити інші ідейно-політичні течії.

Угорське радіо 30 жовтня було реорганізоване у Вільне радіо імені Кошута. А. Мікоян і М. Суслов із занепокоєнням доповідали в Москву, що воно працює поза яким би то не було партійно-урядовим контролем. 1 листопада, однак, коаліційний уряд I. Надя, гостро зацікавлений у розширенні каналів впливу на громадську думку, прийняв спеціальне рішення про радіомовлення, зазначивши, що керівництво ним повинно здійснюватися твердою рукою. Планувалося також перетворити газету «Magyar Nemzet» в урядовий офіціоз [22].

1 листопада на сторінках газети «Új Magyarország» класик угорської літератури Ласло Немет, висловлюючи досить характерні для атмосфери тих днів настрої інтелігенції, писав про те, що весь світ «після цієї приголомшливої революції чекає від нас зразкової моделі політичного устрою», який об'єднує втілення соціалістичної ідеї з угорською національною традицією. Тим часом, в останні дні жовтня до зразкової моделі було дуже далеко. 3 виведенням радянських військ з Будапешта напруженість аж ніяк не спала [23].

31 жовтня було вирішено готувати нову військову акцію, що відбулася 4 листопада. Уряд I. Надя 1 листопада у відповідь на 
введення нових військ з СРСР заявив про вихід Угорщини з Організації Варшавського Договору і звернувся за підтримкою до всієї світової спільноти. Відповідно, уряд І.Надя було повалено, на зміну йому прийшов новий, сформований у Москві уряд на чолі з Я. Кадаром, який був готовий діяти відповідно до волі радянського керівництва. Уже наказ № 2 головнокомандувача об'єднаними збройними силами країн-учасниць Варшавського договору маршала І.С. Конєва «Про створення та організацію роботи військових комендатур» встановлював контроль за всією видавничою діяльністю та засобами масової інформації. Так, Угорщина вступила в новий етап свого розвитку, коли вільній пресі довелося піти в підпілля і відстоювати ідею незалежності в принципово інших умовах, а значній частині журналістської спільноти, зайнятій у підцензурній пресі (включаючи головну газету кадаровської епохи «Népszabadság»), вдатися до саботажу [24].

По-різному склалися долі представників журналістської спільноти Угорщини 1956 року в наступну епоху. Видавець підпільної преси Д. Обершовскі був засуджений до довічного ув'язнення. Журналіст М. Гімеш - головна фігура опозиційного руху інтелігенції в листопаді 1956 року - отримав смертний вирок на процесі у справі Імре Надя і був страчений у липні 1958 року. Близький I. Надю журналіст Г. Лошонци також повинен був постати перед судом, але не дожив, померши в ув'язненні в грудні 1957 року. Заарештовані літератори і журналісти були амністовані на початку 1960-х років. Фактично всі вони займалися потім інтелектуальною працею: на відміну від лідерів Чехословаччини періоду «нормалізації» 1970-х років [25].

Кадар і його оточення вважали непристойним та недоцільним використовувати інтелектуалів як двірників і опалювачів, резонно вбачаючи в цьому ознаку слабкості режиму. Всім цим людям, як правило, знаходилося місце на периферії офіційної культурного життя. Коли в 1963 році на свободу вийшов один 3 найбільших угорських мислителів XX століття Іштван Бібо, питання про його подальше працевлаштування вирішувалося, як і в низці інших випадків, на Політбюро ЦК УСРП. Видатні журналісти, які емігрували на Захід, уже на початку 1957 
року відновили в еміграції газету «Irodalmi Újság». Деякі з них (М. Мольнар, Т. Міра, П. Кенде й ін.) згодом проявили себе як історики, зробивши помітний внесок у вивчення угорської революції. П. Кенде, повернувшись до Угорщини, став у 1990 році одним із засновників Інституту з вивчення революції 1956 року - видного угорського наукового центру в галузі новітньої історії [26].

Усі ці люди, які починали в 1940-1950-і роки як журналісти комуністичної преси, соратники комуніста-реформатора I. Надя, прийшли згодом до переосмислення засад власного світогляду. Вже в 10-річний ювілей революції М. Мольнар доходить висновку: дискусія про історичну роль Імре Надя і його життя закінчилися, його ідеологічні побудови та система цінностей не можуть далі служити відправною точкою для нової епохи. Істориками багато писалося про те, що, незважаючи на свою видиму невдачу, угорська революція змусила обидві наддержави вилучити з неї уроки, а угорський комуністичний режим - змінити свою внутрішню політику. Не менш важливо й інше: при всій суперечливості та всьому трагізмі подій «Будапештської осені» відстоювання демократичних та національних цінностей в Угорщині 1956 року зберігає значення морального прикладу. На слушне міркування І. Бібо, «будапештська осінь» була не просто політичною акцією з певними цілями, це була насамперед «революція людської гідності» [27].

\section{Література}

1.Gyzrkó László A bakancsos forradalom - Bp.: Kossuth, 2001. 542 o.

2. Д.Ткач. Уроки Угорської революції 1956 року. https://library. krok.edu.ua/media/library/category/statti/tkach-0005.pdf

3. Центрально-Восточная Европа во второй половине XX века: В 3 т. - Становление реального социализма: 1945-1965. - М.: Наука, 2000. - Т.1. $-488 \mathrm{c}$.

4. Советский Союз и венгерский кризис 1956 года. Документы / Ред.-сост.: Е.Д. Орехова, В.Т. Середа, А.С. Стыкалин. М., 1998.

5. Середа В.T., Стыкалин А.С. Из истории одного противостояния: союз венгерских писателей в общественно-политической 
борьбе середины 50-х годов // Политические кризисы и конфликты 50-60-х годов в Восточной Европе / Отв. ред. Ю.С. Новопашин. М., 1993. С. 93-145.

6. Советский Союз и венгерский кризис 1956 года. Документы / Ред.-сост.: Е.Д. Орехова, В.Т. Середа, А.С. Стыкалин. М., 1998.

7. Запис бесіди Ю.В. Андропова з головою Ради Міністрів ВНР А. Хегедюш. Пізніше 27 червня 1956 року. Там же. С. 120.

8. АВПР. Ф. 077. Оп. 36. П. 48. Д. 178. Л. $42-51$.

9. Советский Союз и венгерский кризис 1956 года. Документы / ред.-сост.: Е.Д. Орехова, В.Т. Середа, А.С. Стыкалин. М., 1998. C. 341 .

10. Орєхов А.М. Радянський Союз і Польща в роки «відлиги»: 3 історії радянсько-польських відносин. М., 2005.

11. Стылкалин А.С. Прерванная революция. Венгерский кризис 1956 года и политика Москвы. М., 2003. Глава 2.

12. 1956 a sajtó tükrében. Budapest,1989

13. Новое время. М., 1991. № 35. С. 31

14. Президиум ЦК КПСС. 1954-1964. Т. 1. Черновые протокольные записи заседаний. Стенограммы. М., 2003. С. 176-177.

15. 1956 a sajtó tükrében. Budapest, 1989. 84. o.

16. Magyar Nemzet 26.10.1956

17. Советский Союз и венгерский кризис 1956 года. Документы / Ред.-сост.: Е.Д. Орехова, В.Т. Середа, А.С. Стыкалин. М., 1998. C. 383, 441 .

18. Газета «Правда», 28 жовтня 1956 р

19. Béke és szabadság, Magyar Szabadság, Magyar világ. 29.10.1956 -02.11.1956

20. Ворошильский В. Венгерский дневник // Искусство кино. 1992. № 4. С. 131.

21. Петер Сигети Расцвет и закат социал-демократии в Венгрии http://saint-juste.narod.ru/Szigeti.html

22. Советский Союз и венгерский кризис 1956 года. Документы / Ред.-сост.: Е.Д. Орехова, В.Т. Середа, А.С. Стыкалин. М., 1998. Раздел III.

22. Советский Союз и венгерский кризис 1956 года. Документы / Ред.-сост.: Е.Д. Орехова, В.Т. Середа, А.С. Стыкалин. М., 1998. Раздел III.

23. Új Magyarország 01.11.1956 
24. Krónika 1956. Főszerk.: Izsák Lajos. Szerk.: Stemler Gyula. Kossuth Kiadó - Tekintet Alapítvány, Bp., 2006. 174. o.

25. Az 1956-os magyar forradalom. Reform - Felkelés - Szabadságharc - Megtorlás. Történelmi olvasókönyv középiskolásoknak. Tankönyvkiadó, Budapest, 1991

26.Magyarország története 42. rész - 1956: A Szabadságharc, ismeretterjesztő filmsorozat 2009, MTV

27. Csepregi A. Two ways to freedom: Christianity and democracy in the thought of István Bibó and Dietrich Bonhoeffer. Budapest : [s.n.], 2003. 


\section{5. Журналістика в Угорщині за соціалістичних часів 1957-1987 роки}

Новому керівництву Угорщини після 1956 р. дісталася тяжка спадщина. У суспільно-політичному житті панував страх, апатія та недовіра, в економіці - повна розруха. Під пильним контролем з боку Радянського Союзу Я. Кадар мав знайти ту золоту середину, яка б давала можливість, не викликаючи підозри Москви, провадити таку політику, що максимально відповідала б національним інтересам Угорщини за існуючих умов.

Щодо економіки, то 60-70-ті роки були періодом перетворення Угорщини з аграрної держави на промислово-аграрну. В країні за допомогою СРСР були збудовані металургійні, хімічні, нафтопереробні, фармацевтичні, машинобудівні заводи та комбінати. Більшість цих виробництв забезпечували сировиною з Радянського Союзу, і вони були повністю розраховані на ринок країн Ради Економічної Взаємодопомоги (РЕВ). Цим самим Угорщина міцно прив'язувалася до соціалістичного табору, й будь-який розрив із системою був досить проблематичним, насамперед з економічного погляду. В сільському господарстві до середини 1962 р. практично було завершено колективізацію, 96 відсотків площ орних земель перейшло до рук кооперативів.

Водночас, уся система була побудована на директивній плановій економіці, цілковитій державній власності на засоби виробництва. Тому вже на початку 60 -х років внутрішні ресурси системи вичерпалися, і вона почала давати серйозні збої. Зниження темпів економічного розвитку, дефіцит товарів широкого вжитку та продуктів харчування, слабка забезпеченість соціальних програм для населення потребувала реформування народногосподарського комплексу. 
3 січня 1968 р. розпочався процес реформування угорської економіки [1, с. 264]. Однак, після відомих подій 1968 р. у Чехословаччині впровадження в життя угорських реформ було значно уповільнено, а після 1973 р. практично припинено.

На початку 80-х років угорський соціалізм переживав усі ознаки системної кризи. Керівництво країни, пам'ятаючи події 1956 р., продовжувало політику підтримання високого життєвого рівня за рахунок насамперед іноземних кредитів. Обсяг заборгованості країни за 80-ті роки збільшився вдвічі, їі сума дорівнювала річному національному доходу країни. На той період Угорщина мала найвищу заборгованість на душу населення серед соціалістичних країн [2, с. 45]. Усе це призвело до значного дефіциту державного бюджету країни, інфляції, зниження купівельної спроможності населення, зростання безробіття. У суспільстві знову заговорили про кризу довіри до влади. Під тиском обставин УСРП повертається до ідей реформування економіки середини 60-х років. Починаючи з 1981 р., дозволено створювати «малі підприємства», насамперед у сфері торгівлі та обслуговування. Легалізовано індивідуальну трудову діяльність і роботу за сумісництвом, поширилися трудові кооперативи у виробничій сфері, зокрема в легкій промисловості. До речі, саме капітали, зароблені в цій сфері, слугували основою для проведення на початку 90-х років приватизації, створення середнього класу власників.

У політичному житті також розпочалися зміни. На вибори до парламенту було дозволено висувати не одного, а кілька кандидатів. У засобах масової інформації все частіше з'являлися критичні виступи щодо економічної ситуації в країні, про становище угорців за кордоном, переважно у Трансільванії. Як правило, ці виступи залишалися «непоміченими» з боку партійної еліти.

У цьому зв'язку потрібно звернути увагу на таку обставину. В угорському «соціалістичному» суспільстві завжди був присутній моральний, а за можливості й реальний спротив радянському диктату. Причому це неприйняття всього радянського не залежало від того, яку посаду людина обіймала в державнопартійній ієрархії. I тому щойно з'явилася невеличка можли- 
вість без особливого ризику розпочати опозиційну боротьбу, одразу почали формуватися різноманітні союзи, товариства, громадські організації. Активізувалися вчені-економісти, політологи, які своїми публікаціями заснували своєрідну ідеологічну базу опозиції, роз'яснювали причини кризи, пропонували шляхи виходу з неї та обгрунтовували необхідність політичних змін. Серед них були і досить відомі партійні функціонери, зокрема I. Пожгаї, М. Сюреш та ін. Так, комуніст-реформатор М. Біхарі у своїх численних публікаціях відкрито зазначав, що із ситуації, яка склалася, можливий тільки один вихід - зміна існуючого суспільного ладу [3].

Роль своєрідного каталізатора демократизації суспільства в ті роки активно відігравала Спілка письменників Угорщини. I хоч ЦК УСРП досить жорстко ставився до Спілки (1983 p. відповідні санкції було вжито до редактора журналу «Mozgo Vilag», a 1986 р. - розформовано редакцію літературного журналу «Tiszatai»), письменники не здавалися. У листопаді 1986 р. на загальних зборах Спілки до керівництва організації не було допущено жодного члена УСРП, що практично означало відкриту конфронтацію більшості письменників із владою.

У середині 80 -х років уже стало зрозуміло, що угорське суспільство готове до найбільш кардинальних змін суспільного ладу. Зупинка була лише за одним - наскільки Москва була готова відпустити Будапешт зі своїх обіймів. Тому прихід до влади в Кремлі М. Горбачова сприйнявся в Угорщині, як і в інших соціалістичних країнах Європи, надто оптимістично. Угорцям у цей момент, саме на цьому відтинку історії, потрібен був такий Генеральний секретар, який скаже: «Йдіть, куди хочете. До Європи - то до Європи, до капіталізму - то до капіталізму абощо». Саме так і сталося. На цьому, практично, завершується третій етап побудови «розвиненого соціалізму» в Угорщині й розпочинається четвертий етап - етап підготовки повалення тоталітарної системи та переходу до суспільства, що засновується на принципах демократії і ринкової економіки, впровадження багатопартійної системи[4]. Прийшовши до влади, уряд Кадара хотів раз і назавжди припинити всі форми журналістського опору. Як один із яскравих проявів цього політичного менталітету 
Яноша Кадара, прозвуча така позиція у його зверненні під час дебатів з делегацією Угорської спілки журналістів на Державних зборах 10 грудня 1956 року: «Якщо ви думаєте, що в Угорщині буде опозиційна журналістика, то ви будете розчаровані!».

Режим Кадара не терпів навіть «лівої» опозиції. Прибувши до Сольноку з радянськими військами, Ержебет Андіч та Андор Берей 6 листопада 1956 р. перезапустили Szabad Nép як центральний орган Угорської соціалістичної робітничої партії. Газета, яка підтримувала лінію Ракоші, була доставлена в Будапешт радянськими військовими вантажівками і розповсюджена серед читачів. За вказівкою Кадара, 11 листопада Népszabadság розпочала різкий наступ на Szabad Nép, у результаті чого вона була закрита, а подружжя Андіч-Берей заарештували і відправили в заслання до Радянського Союзу, їх позбавили всіх своїх прав, і навіть депутатства у Державних зборах [5].

Для політичної атмосфери протягом тижнів після поразки революції характерно, що народ або не купував Népszabadság i Népakarat, або спалював, або розривав їх публічно, через те що ці газети намагалися виправдати відновлення диктатури радянського типу. Тібор Дері в своєму щоденнику розповів, що люди купують Népszabadság у п'яти примірниках, виривають останню сторінку, де $\epsilon$ новини про Олімпіаду в Мельбурні, а потім спалюють решту. Поліцейський просто дивиться і відвертається [6].

Як правило, навіть журналісти на початку не брали в руки Népszabadság, тому газета тижнями виходила без звичних реквізитів: ні відповідального редактора, ні відповідального видавця, статті з'являлися без імені або лише з ініціалами прізвища автора, навіть не вказували, в якій друкарні була надрукована.

13 листопада Угорська спілка письменників висловила підтримку уряду Імре Надя як законній Раді міністрів та приєдналася до проголошеної декількома інтелектуальними й мистецькими організаціями заяви на тему «Демократичний соціалізм 3 урахуванням незалежності країни та національних особливостей».

Суперечливість ситуації відображається в тому, що 24 листопада навіть журналісти з Népszabadság страйкували. У своє- 
му виступі 11 листопада президент Югославії Йосип Броз Тіто визнав уряд Кадара, але також критикував радянську політику. Газета Радянської комуністичної партії «Правда» гостро відреагувала на критику Тіто. Провідні журналісти Népszabadság намагалися у відповідь критикувати газету радянських комуністів і висловили свою незгоду з іiі позицією. Однак Кадар відкликав цю статтю й заборонив її публікацію. Справа була передана до Тимчасового адміністративного комітету, який вирішив, що Népszabadság повинна публікувати і статті «Правди», і югославської «Борби». Тоді журналісти Népszabadság вирішили донести свою позицію в більш спокійному тоні, але це також не влаштувало керівництво партії. Кадар зателефонував до редакції газети й з криком заявив, що «якщо ви не зміните свою позицію, то ми вас звільнимо з роботи!». Коли журналісти дізналися про все це, вони оголосили страйк. Кадар замінив Лайоша Фегера, головного редактора, на Іштвана Фріш.

Керівництво партії хотіло закріпити свою владу, «влаштувавши перевірку практично всім журналістам». Одна з причин, яка це пояснювала, була та, що радянське керівництво вважало угорських письменників і журналістів головними лідерами революції 1956 року.

24-25 травня 1957 року польські партійні та державні лідери зустрілися з радянськими лідерами в Москві, Хрущов зазначив: «Жоден із робітників чи селян не воювали проти радянських військ». Жуков: «Інтелігенція воювала». Хрущов: «Письменники, журналісти». Сте́фан Ендрихо́вский: «Там було не так багато письменників». Хрущов: «Це була організація. Не слід вважати, що це чиясь особиста ініціатива, вони діяли лише під чиїмось керівництвом та 3 чіткими вказівками».

Спочатку майже всіх журналістів звільнили, а потім залишили лише тих, хто, за словами Кадара, поводив себе належним чином під час «контрреволюції». Уряд Кадара навіть Угорську спілку письменників позбавив офіційної автономії.

На підставі розпорядження Міністра збройних сил та громадської безпеки Ференца Мюнніха було усунуто все керівництво Угорської спілки письменників та призначено урядового комісара Норберта Шіклюші. 18 та 20 січня випуски 
Népszabadság повідомляли про це рішення, виправдовуючи його тим, що Угорська спілка письменників «відкрито виступали проти консолідуючих зусиль партії, займаючись діяльністю, що суперечить інтересам Угорської Народної Республіки». Рішення ЦК УСРП від 2 липня 1957 р. підсумувало «результати» таким чином: « Після 4 листопада 1956 р. за допомогою радянських військ Міністерство збройних сил разом з армією завдало значних ударів силам контрреволюції. Вони розпустили ради робітників Будапешта та округів. Призупинивши, а потім заборонивши право Угорської спілки письменників діяти, внутрішні, відкриті ідеологічні центри контрреволюції були значною мірою демонтовані»[7].

Перегляд членства в Угорській спілці письменників розпочався в серпні 1957 року. До 1956 року в УСП було 2200 членів, 800 з яких відмовилися від членства, близько 60 отримали різні покарання, відсторонення, догани, попередження. Характерним є те, що ЦК партії ввело новий порядок формування керівництва спілки, тепер воно не обиралося членами, а комітетом 3 питань висунення кандидатур, який складається 3 надійних кадрів. Таким чином, 2 червня 1958 року УСП очолив Арпад Шакашіч, а Норберт Шіклоші, колишній урядовий комісар, став генеральним секретарем.

Кадар доручив Іштвану Сірмаю зламати опір журналістів: у грудні 1956 р. його призначили урядом керівником новоорганізованого управління преси.

Сирмай, який сидів у в'язниці при Хорті та Ракоші, застосував тактику «батога і пряника» до письменників та журналістів 3 певним цинізмом.

3 метою залякування журналістського товариства були проведені один за одним позови до суду, засуджуючи письменників і журналістів: позов проти Тібора Дері та його колег (так званий великий позов) тривав 325 жовтня 1957 року до 12 листопада 1957 року. Головним суддею був той самий Ференц Віда, який також керував процесом проти Імре Надя. 3 чотирьох підсудних письменник Тібор Дері був засуджений до 9 років в'язниці, письменник Дюула Гай до 6 років в’язниці, поет Золтан Зелк до 3 років в'язниці, а письменник Тібор Тардош до півтора років 
в'язниці. Міклош Гімеш був заарештований 5 грудня 1956 p. i засуджений до смертної кари та страчений як обвинувачений у процесі Імре Надя. У цьому ж позові Міклош Вашарелий був засуджений до 5 років позбавлення волі. Геза Лошонці у так званому кримінальному провадженні на стадії розслідування загинув у в'язниці.

24 червня 1957 року Дюла Обершовський був засуджений до смертної кари судом за звинуваченням у «організації змови проти держави». Міжнародний протест з цього приводу розпочався після винесення вироку, і нарешті влітку 1957 року генеральна прокуратура подала протест проти цього рішення суду, й вирок був відмінений, і він був засуджений до довічного ув'язнення. 19 серпня 1958 року Шандор Харасті був засуджений до шести років, а Дьордь Фазекаш - до десяти років позбавлення волі. 9 жовтня 1957 року Верховним судом Домокош Варга був засуджений до двох років в'язниці, а Арон Тобіаш - до одного року. Шандор Фекете був засуджений до 9 років у процесі суду над Ференцом Мереєм та іншими. Андраша Шандора засудили до 8 років в'язниці. 14 травня 1958 року Пал Лачей був засуджений до 8 років позбавлення волі. Іштван Лакатош був засуджений до двох років та десяти місяців ув'язнення. Балаш Ленг'єла, Тібоpa Петьо, Болдіжар Івана тримали в слідчому ізоляторі[8].

Багато хто змушений був емігрувати: Тамаш Акшель, Дьордь Фалуді, Тібор Мерай, Пал Ігнотус, Міклош Молнар, Дьордь Палацо-Горват та ін.

Режим Кадара створив ситуацію, коли будь-які протистояння здавалися безнадійними. Той, кого виключили зі Спілки письменників, оскільки він не відповідав встановленим умовам, міг навіть померти з голоду, адже його не брали на роботу в державні газети й журнали. Довгий час літературні журнали не могли публікувати нові вірші, новели та інші твори. Стандарт преси знизився до рівня найтемніших років епохи Ракоші.

На весняній сесії Державних зборів Янош Кадар уже з задоволенням повідомляв про досягнуті «результати» в роботі 3 журналістами: «Я спілкувався 3 журналістами, вони виступали за більшу свободу і за те, що їх не критикували. Я сказав їм, що це не гарний розподіл праці. Виявляється, що лише уряд робить 
помилки, а журналісти про це пишуть та дають негативні оцінки. Ви гарно влаштувалися».

Янош Кадар доручив письменникам та журналістам визнати, що 23 жовтня в Угорщині не було революції і закликав їх присвятити всі свої зусилля цьому поясненню для населення. Навіть у режимі Кадара журналісту все ж довелося працювати солдатом партії. Преса залишалася, згідно з ленінськими принципами, колективним агітатором, колективним пропагандистом та колективним організаторомр[9].

У результаті революції 1956 р. та війни за незалежність підготовку журналістики на рівні університету було скасовано, а кафедру журналістики університету Етвош Лоранда було розпущено. Підготовку журналістів узяли на себе навчальні заклади Угорської спілки письменників. Але абітурієнт міг потрапити в ці журналістські школи лише тоді, коли він уже працював журналістом газети. У той же час, влаштуватися на роботу в газету, могла людина з дипломом журналіста. Ця пастка також посилила вразливість журналістів і всесилля влади.

Мовні навички журналістів також були нижчими, ніж інтелігенції загалом, хоча останні також значно відставали від рівня знань освічених верств населення у західних країнах. У цей період пересічний угорський журналіст не розмовляв іноземною мовою, а якщо і розмовляв російською мовою, то погано. Звичайно, однією з причин цього було обов'язкове вивчення російської мови в закладах освіти та міжнародна ізоляція.

Уряд Кадара стабілізував свої позиції до 1958 року, вони наважилися на проведення парламентських виборів, а в червні були скликані загальні збори Угорської спілки письменників.

Саме тоді було оголошено, що журналісти, які не підтримують лінію колишнього керівництва УСП, чітко займають позицію на користь нового керівництва, можуть не лише продовжувати свою роботу як журналісти, але й отримувати різні пільги. Їм та членам їхніх сімей обіцяли підвищення заробітної плати, вирішення їхніх житлових проблем, можливість брати участь у пільгових внутрішніх та закордонних поїздках під час відпусток, вивчення іноземної мови й безкоштовні квитки на літаки та потяги. Вони також отримували безкоштовні запрошення на 
вистави театру і кіно. У добу Кадара ці пільги були додатково розширені за допомогою можливості придбати автомобіль без черги, встановлення телефону, пільгового кредиту Ощадбанку тощо[10].

У той час партійне керівництво змогло проводити свою лінію через членів партії, що працювали у редакціях. До 1956 року кількість членів партії в основних газетах становила від 80 до 90\%. За часів Кадара ця кількість дещо зменшилася, але лише члени партії могли бути керівниками друкованого органу. Лише два головних редактори літератури були безпартійними: Ференц Югас, головний редактор «Íj Írás and Deme», та László Deme керував журналом для дітей Kincskereső, який виходив у Сегеді.

Головні редактори могли виходити лише 3 числа найбільш довірених партійних кадрів, і зазвичай вони були членами найвищих партійних органів, тому головний редактор Népszabadság був членом ЦК партії, а головні редактори повітових газет були членами відповідних комітетів партії.

Виходячи $з$ вимог до журналістських кадрів, ЦК УСРП призначав головного редактора та членів редакції газети Népszabadság, кореспондентів УТА, які працювали за кордоном, головних редакторів газет і журналів: a Figyelő, a Néphadsereg, a Ludas Matyi, a Népsport, a Képes Újság, az Ország Világ, a Kortárs, az Új Írás, a Film-Színház-Muzsika főszerkesztőinek, a Népszava, a Magyar Nemzet, az Esti Hírlap, a Nők Lapja, a Magyar Ifj úság, a Hétfói Hírek, az Élet és Irodalom, а також заступників головних редакторів a Szabadföld та відповідальних редакторів обласних партійних видань[11].

Під час призначення журналістських кадрів усіх рівнів залучали політичну поліцію для перевірки їх надійності. Історія кожного кандидата досконало вивчалася, розпочинаючи від бабусь і дідусів. Попередні професії, місця навчання та роботи, систему стосунків, друзів, родичів, близьких родичів, подружжя, побратимів тощо. Вони вивчали ставлення кандидата до Радянського Союзу, партії, «соціалістичного будівництва», політичних кампаній, віросповідання тощо.

Окрім головного редактора, існувала редакція, яка в часи 
Кадара приймала дві форми. В одному випадку редакція складалася з керівників, які працювали над газетою чи журналом: заступника головного редактора, редактора випуску, партійного секретаря. В іншому - це були представники спеціальних органів.

У ті часи цензура була досить суворою, наприклад, Magyar Nemzet про зустріч Імре Пожгаї, одного із соціалістівреформаторів, 3 населенням м. Локітелек надрукувала звіт лише через місяць. Угорські читачі газет могли дізнатися про утворення Фідес у Magyar Hírlap: у матеріалі, який відповідав старій, партійній тональності: «1988-й. 30 березня 1988 року група студентів та молодих інтелектуалів університету ініціювала створення нелегальної організації, тому 8 квітня 1988 року компетентні органи міліції попередили Міклоша Андраші із Дунаюйвароша, Віктора Орбана з Сольнока та Івана Чабу, Ласло Ковера та Андра Рача - мешканцям Будапешта. Цим особам було запропоновано припинити свою діяльність» [12].

У 50-х роках через високу ізоляцію керівництво партії зосередилося майже виключно на внутрішньополітичній журналістиці. Щодо журналістів, які займалися зовнішньою політикою, то вони брали інформацію із зарубіжних інформаційних агентств. У добу Кадара в пресі часто було більше новин про третю світову війну, ніж про Угорщину. У холодній війні через протистояння двох великих держав та військових блоків усе вважалося важливим: В'єтнам, Ангола, Чилі, Нікарагуа тощо були на перших шпальтах провідних газет.

Зовнішньополітична журналістика спочатку базувалася на дуже простому шаблоні, який Петер Варконі виклав так у 1964 році: «Завдання журналістів викривати позиції Заходу». Коли, наприклад, Янош Кадар або інший лідер їхав у західну країну, не можна було критикувати політику цієї країни деякий час. Порушення цього спричинило дисциплінарні заходи [13].

Однак, викриття розвинених західних країн стикається зі зростаючими труднощами. Навіть висвітлення політичних скандалів свідчило про те, що там працює демократія. Звіти про нещасні випадки та стихійні лиха показали, наскільки там вищий рівень життя та як працює громадянське суспільство. 
До кінця 1980-х років було правило, що про інші соціалістичні країни, особливо Радянський Союз, можна було повідомляти в пресі лише з матеріалів інформаційних агентств цих країн.

Через замовчування радянського керівництва угорським читачам не вдалося вчасно повідомити про вибух та радіацію на Чорнобильській електростанції 26 квітня 1986 року. Хоча Горбачов протягом року вже був лідером Радянського Союзу й оголосив політику гласності, лише після 5 травня в угорській пресі з'явилися новини про специфіку аварії та необхідні запобіжні заходи.

Давалися також інструкції щодо того, яку саме пропаганду слід вести, як представляти певні події, як пояснити проблеми, що не вдалося приховати. Наприклад, економічні труднощі з витратами на гонку озброєнь, злочинність, корупцію потрібно пов'язувати 3 впливом капіталістичного середовища. 3 іншого боку, увагу читачів потрібно було звернути на зростання виробництва та споживання, на безпеку існування в соціалістичних країнах, у тому числі Угорщині.

Як найбільш безпосередній засіб ручного контролю, у редакціях була встановлена пряма телефонна лінія для зв'язку провідних журналістів з ключовими партійними офісами.

Режим Кадара зробив висновки з культу Ракоші, через який угорське населення стало імунізованим до прямої політичної пропаганди після 1956 року. Тому культ Яноша Кадара був побудований більш опосередковано, хитро й образно. Фотопортретів Кадара було набагато менше у державних установах, у пресі, жодні заводи та установи не були названі його іменем за життя тощо. Книга-біографія Яноша Кадара була набагато дешевшою, ніж інші подібні видання (всього 26 форинтів), а іiі перше видання у 100000 примірників було розкуплено за кілька днів. Видавництво Magvető Könyvkiadó спочатку повідомило, що перевидання книги було «технічно нездійсненним», але через 3 дні десятки тисяч примірників 3'явилися у книгарнях по всій країні. До 1986 року книга була перевидана чотири рази, i iï тираж досяг півмільйона примірників [14].

У випадку культу Яноша Кадара легенди, які діяли неформальними каналами, підкріплені шепотом пропаганди, здава- 
лися важливішими, ніж публікації в пресі. Про Кадара розповсюджувалися слухи, що він був скромною, чесною, працьовито людиною. Він особисто переживав за добробут та клопоти робітників. Окрім того, згідно зі статтею, опублікованою в західній емігрантській пресі, вважалося, що Кадар піддавався катуванню у катівнях поліції Ракоші.

Він працював для угорського народу день і ніч 3 моменту звільнення з в'язниці. У 1956 році угорці з Кадаром отримали менше зло, оскільки Ракоші чи його жорстокі поплічники могли повернутися до влади. Кадар уміло лавірував між вимогами московських лідерів та інтересами угорського народу. В нього $є$ свій розум, якби тут не було радянських окупаційних військ, він би зробив країну заможною, а людей багатими [15].

Преса епохи Кадара показала своєрідне обличчя дволикого Януса. Ідеологічні засади все ще повинні були повторюватися як «молитовний млин». Нудні, заповнені штампованими фразами, святковими реляціями газетні сторінки мали викликати інтерес у читачів. Політична пропаганда все ще ставила Леніна прикладом політичного публіциста: «Стиль, міркування та мобілізація сили ленінської журналістики з тих пір слугували прикладом для всіх комуністичних публіцистів. Ленін завжди знаходив проблему, яка найбільше турбувала робітничий клас у той час, і писав про це. Його статті завжди сперечалися, аргументували, розкривали, вели за собою вірним шляхом».

Однак, особливо з другої половини шістдесятих років, керівники преси намагалися створити більш сприятливий, демократичний вигляд газет та журналів, тому вони доручили редакціям зробити пресу більш барвистою і цікавою, надавати менше місця політичним жанрам, щоб з'явилося більше спорту, загадок, вікторин та розваг.

Звичайно, вони теж повинні були написані так, щоб передати непрямі, майже непомітні, але політичні повідомлення. Першою спробою цього нового виду журналістики став різдвяний номер 1956 року «Népszabadság». Редакція за вказівкою уряду Кадара використовувала майже всі можливі засоби для поліпшення громадського настрою. На титульному аркуші невелика сосна, стаття Джули Секфа, дитяча сторінка, картина Дієго Ве- 
ласкеса «Три царі», вірш Аттіли Йожефа «Віфлеємські царі», написана Фрідішом Карінті, коротка добірка із західних різдвяних листівок, реклама та кросворди. Цей номер вийшов у понад мільйон примірників[16]

У той час кожен соціальний прошарок, група та вікова група в Угорщині мали свою газету чи журнал. Газета керівної партії, Népszabadság, мала найбільшу кількість примірників (765 тис. на день); газета профспілки, Népszava; газета Magyar Nemzet Народного фронту. 31968 р. друкується урядова газета Magyar Hírlap.

Щотижневиком для жінок був Nök Lapja (759 000 примірників); сторінка жарту - Ludas Matyi (531 тис. примірників); кольорові газети: a Képes Újság, az Új Tükör; політичний тижневик - Magyarország; літературний журнал Nagyvilág és a Szovjet Irodalom. Щомісячні центральні журнали: Kortárs, Új Írás, Kritika, Mozgó Világ. Газета провінції: Szabad Föld (503 тис. примірників). Провінційні журнали: Great Plain, Present, Source, Today, Our Life, New Source, Workshop, Somogy, Dunav, New Aurora, Jászkunság, Palócföld, Tiszatáj. Молоді: Magyar ifj úság (273 тис. примірників), піонери: Pajtás, Kisdobos, для дітей: Dörmögö Dömötör. Спортивна газета: Népsport. Esti Hírlap. Speciális jellegüek: «Таблоїд»: Esti Hírlap. Особливості: Látóhatár, Rakéta regényújság, Kincskereső[17]. Унікальний профіль видання визначався, з одного боку, його власником, а з іншого - цільовою аудиторією. Відповідно, крім загальнообов'язкового загального змісту, в Népszava готувалися профспілкові новини, у Magyar Nemzet - інформація про діяльність Народного фронту. Esti Hírlap розповідала про події життя УСРП м. Будапешта.

Népszabadság, як центральна газета партії, мала особливий статус та найбільшу кількість примірників і найбільшу та найкраще обладнану редакцію. У 1967 році часопис мав власного кореспондента в Москві, Празі, Берліні, Парижі, Римі, Лондоні, Вашингтоні та Ханої. I в багатьох містах працював спільний кореспондент газети та УТА[18].

Népszava була другою за тиражом газетою в Угорщині. Як профспілковий часопис, вона хотіла бути цікавою для робітників, більший акцент робити на питаннях виробництва і фабрич- 
них робіт. Редакція також намагалася розібратися з проблемами та турботами простих людей. Тому статті в ній були коротшими й простішими, ніж статті у Népszabadság та Magyar Nemzet.

Magyar Nemzet з'явилася 7 вересня 1957 року як газета безпартійної інтелігенції. Це вимагало також вищого стандарту до публікацій, а саме тон статті повинен базуватися не на емоціях, а на розумі. «Однак це емоційне виховання не може бути пропагандистським, оскільки тоді воно втратить своє призначення. Це повинно бути дуже стриманим, майже непоміченим. Будучи інтелектуальним виданням, ми хочемо апелювати не стільки до емоцій, скільки до інтелекту. Отже, ми повинні усвідомлювати особливу історичну ситуацію, до якої ми мусимо пристосуватися, оскільки ми не можемо іiі змінити, а спроба змінити іiі обов'язково зазнає невдачі й, таким чином, не може бути в національних інтересах».

Виходячи з цих міркувань, образ угорської нації визначався насамперед зовнішньополітичною та культурною складовими. Він єдиний у той період представляв традицію титульної журналістики, і його твори були набагато більш літературними, таким чином вирізняючись 3 угорської преси. Також було винятковим те, що до 1982 року його редагували відомі безпартійні журналісти Ерн Міхаліфі та Тібор Пет. Поступово Magyar Nemzet мала все більше можливостей повільно й обережно розширювати рамки, встановлені владою, i, таким чином, висловлювати обережні думки серед інших статей - звісно без протистояння владі. У 1980-х роках газета перейшла під контроль Імре Пожгаі та стала підтримувати реформи й докорінні зміни у суспільно-політичному житті. Як результат, до 1989 року часопис досяг 170000 примірників.

У 1968 році засновано урядову газету Magyar Hírlap. Як «офіційний» часопис уряду, головним завданням вона мала представляти позицію уряду. Засновники плекали надію, що цей часопис посилить конкуренцію між газетами й тим самим сприятиме підвищенню рівня вітчизняної журналістики. Газету випустили спочатку в 40000 примірників, і вона була розрахована на державних чиновників та партійних функціонерів. За часів, коли прем'єр-міністром був Карой Грос, у газеті було 
опубліковано багато важливої інформації про діяльність уряду, гострі проблеми соціально-політичного життя, і невипадково у 1988 році кількість їі примірників виросла до 100 000[19].

У грудні 1956 року вийшла газета Esti Hírlap, яка була газетою Будапештського комітету партії та задумувалася як свого роду «соціалістичний таблоїд». Як маскування, на її заголовку стояло гасло «Незалежний політичний щоденник», але ніхто не сприймав це серйозно. Кількість примірників часопису поступово збільшувалася аж до 300 тис., оскільки вона надавала людям, що поверталися з роботи, відносно актуальну інформацію. Зовнішні та внутрішньополітичні новини й різного роду статті писалися доступною для простої людини мовою, публікувалися більш легким тоном.

Навіть таблоїдна журналістика не могла як слід розгорнутися, оскільки всі форми журналістики були підпорядковані офіційній ідеології та пропаганді, включаючи кримінальне висвітлення. 3 одного боку, повинна бути обгрунтована думка про те, що злочинність пов'язана з капіталізмом, експлуатацією, а при соціалізмі вона повинна зникнути або принаймні зменшитися на порядок, а з іншого боку - мали бути представлені злочини, здійснені ворогами держави[20].

В областях у результаті скорочення, здійсненого у 19491950 роках залишилося 19 газет. Майже всі часописи у містах були закриті. Лише Сегед зберіг Délmagyarország, а бюлетень Dunaújvárosi Hírlapot був виданий у Дунауйвароші, а потім Dunántúli Naplót у м. Печ у 1960-х роках. 78\% населення провінції читали повітові газети, і відповідно, кількість їх примірників постійно зростала: до 1987 р. вони досягли 1407000 . Це сталося, незважаючи на низьку зарплату журналістів у повітових газетах, саме тому багато хто з них намагалися влаштуватися на роботу в столичні газети. Частково через це було мало професіоналізму в цих газетах, місцевих новинах. Вони пропускали найважливіші події, а їх культурні колонки були нудними.

У цей час заводські, фабричні партійні комітети розпочали випускати невеличкі газети для заохочення кращої роботи та підвищення трудової дисципліни. У диктатурі радянського 
типу державне підприємство було не лише виробничою одиницею, але й одиницею державного управління 3 державними повноваженнями. Тому, особливо в час економічного розвитку, у 60-70-ті роки кількість заводських газет зросла. Після 1968 року, коли автономність підприємств зросла, ради директорів також намагалися підвищити власний престиж через друкування у цих виданнях статей про свою роботу.

У середині 60-х років було видано лише 77 заводських газет та 63 заводські бюлетені, а у 1970 році їх було понад 200, у 1975 р. 374, а в 1980 р. 609, кількість примірників сягала півтора мільйона.

Щотижневі газети також відігравали значну роль у інформаційному просторі режиму Кадара. Майже кожен соціальний прошарок суспільства мав свою щотижневу газету. Не було лише видання, що стосувалося внутрішньої політики.

Élet és Irodalom з'явилася 15 березня 1957 року як спадкоємниця Irodalmi Újság, яку було закрито за іï активну участь у подіях 1956 року. Першим їі головним редактором був Дьордь Болоні, який сповідував соціалістичний реалізм. Лайош Мештерхазі, автор книги «Життя і метод роботи стахановського бетонника», Лайоша Карача (1950) одними з перших перейшли на бік уряду Кадара.

У початковий період одні й ті ж імена майже завжди можна було прочитати серед авторів статей, оскільки багато хто відмовився публікувати свої статті, незважаючи на скрутні умови життя. На той час Ласло Немет заявив про газету, що хоч їі назва «Життя і література», але в ній не було «життя» чи «літератури».

У 60-ті роки редактори, відомі своєю «сектантською непримиренністю» та неякісною роботою, були замінені на Імре Добозі, а потім на Дьордя Немеші, за часів редагування якими газета стала цікавою та популярною. Пізніше навіть ті, хто раніше відсиділи у тюрмі, могли публікуватися в газеті, наприклад: Дюла Фекете, Золтан Молнар, Тібор Дері, Золтан Зелк тощо. Іштван Еркені також став друкуватися в Élet és Irodalom уперше після того, як йому заборонили журналістську діяльність. У 70-х роках газета вийшла до 70000 примірників, у першій по- 
ловині 80-х через читацький попит продажі газет зросли до 120 000, але влада з політичних причин обмежила їх до 60000 . У тижневику публікується все більше і більше творів, які гостро критикували систему. Читачі з вдячністю отримували глибокі аналітичні статті, спритно замасковану критику, що все більше і більше не подобалося партійному керівництву. Так, наприклад, саме 7 листопада газета опублікувала критику радянської п'єси.

У результаті економічної реформи політичне керівництво побачило необхідність започаткувати часопис, який би роз'ясняв лінію партії у цій царині. Ось чому був заснований журнал Világgazdaság, який - єдиний в угорській пресі - друкував матеріали найбільших західних інформаційних агентств (Reuters, AP-DJ, UPI). Усі інші угорські ЗМІ могли працювати з відфільтрованими новинами, отриманими від УТА. Саме це змусило владу закрити Világgazdaság для широкої публіки, зробивши журнал тільки «Для внутрішнього використання».

Тому партійне керівництво прийняло рішення започаткувати випуск ще одного щотижневого журналу про світову економіку, який вже міг би купити кожен і який інформував з поточних економічних питань популярною та зрозумілою мовою. Ось так i розпочав свою діяльність щотижневик світової економіки (HVG) з дозволу відділу агітації та пропаганди Центрального Комітету УСРП і Угорської торгової палати (власника журналу).

HVG незабаром став одним із найуспішніших журналів того часу завдяки сучасній формі, змісту та мові. Його кореспонденти намагалися впровадити стиль англосаксонської журналістики в Угорщині. Вони вміло маневрували між вимогами партії та професійними нормами. Як заслуга головного редакторазасновника Вінце Матяша, журнал, який вийшов друком лише 23000 примірників у 1983 році, до 1986 року досяг 132000.

Газета Magyarorszag, стала більш відкритою після призначення Йожефа Палфі головним редактором у 1963 р., але - всупереч своїй назві - публікувала зовнішньополітичні статті, головним чином використовуючи матеріали західних газет.

Після 1956 року виходило все більше щотижневих газет: Bunte, Bild, Stern, Life i т.д., вони видавалися за прикладом західних видань. Успішними були жіночий журнал «Képes Újság», 
«Tükör» i «Ország Világ». До 1969 р. ці видання налічували разом 1 мільйон 140000 примірників, а їхня читацька аудиторія була значно більшою, оскільки їх зазвичай читали декілька членів сім'ї. Політичне керівництво очікувало, що ці щотижневі газети будуть розглядати питання, які вважаються актуальними та цікавими для багатьох читачів, і прагнули включати в їх зміст політичну пропаганду в завуальованій формі, щоб статті, що легко читаються, могли ефективно сприяти підвищенню політичної грамотності населення.

Таким чином, вони опинилися між двома вогнями: $з$ одного боку, вони мали видавати газету, яку можна було продати у великій кількості, а з іншого - вона мала відповідати політичним завданням. Верховне партійне керівництво на чолі з Яношом Кадаром постійно критикувало зміст газет. Жіночий журнал, наприклад, звинувачували у тім, що прочитавши його, марсіанець дізнається про Угорщину лише те, що тут живуть жінки. Вони критикували їх за те, що в газетах друкують багато сенсаційних матеріалів, кримінальні повідомлення, які не відповідали межам доброго смаку, «вимушену еротику».

Були створені журнали для жінок: Nok Lapja, a Nok Magazinja, a Lanyok - Asszonyok, що повинні були здійснювати гендерну політику партії. Теми, які вони заторкували, стосувалися зайнятості жінок, вибору кар'єри та соціальних проблем. Nok Lapja був найпопулярнішим із цих журналів і досяг найбільшої кількості примірників, виходив у невдалому форматі до 1956 року, на обкладинці були представлені дівчата-трактористки та стахановки. За часів Кадара зовнішній вигляд та зміст тижневика змінилися на краще. 3 його все більш естетичним виглядом він став набагато читабельнішим. Його журналістами були: Галшаї Понграц, Іллеш Дюла, Йожі Йено, Йожі Тершансуі, Томаші Арон, Дюрковіч Тібор, Цурур Іштван. У той же час, діяльність журналу була під пильним оком партії. У звіті відділу агітації та пропаганди Центрального комітету Угорської соціалістичної робочої партії, який був підготовлений у 1986 році, говорилося: «Є щотижневі газети, чия просвітницька робота погана або зовсім погана. У цьому відношенні особливо критиці підлягає популярний Nok Lapja, який у своїх статтях, портфоліо та віршах 
часто йде на поступки дрібнобуржуазному смаку, моральному спрощенню й кітчу. Nok Lapja та ще кілька тижневих газет абстрактно розглядають певні негативні суспільні явища (розлучення, проституцію, правопорушення серед неповнолітніх, пияцтво тощо)» [21].

Country World був часописом «угорсько-радянської дружби», його завданням було розповідати про успіхи у побудові соціалізму в СРСР та інших соціалістичних країнах, хоч тираж журналу був майже двісті тисяч примірників, особливою популярністю у читачів він не користувався.

16 березня 1964 року розпочав свою діяльність Tukor, як зрілий політичний та соціальний тижневик. Потім, у 1976 році, Імре Кашаді разом із Шандором Фекетом та Ласло Беняміном заснували культурний тижневик Uj Tukor. Дюла Іллієс, Шандор Чоурі, Дьордь Конрад зуміли залучити до його роботи майже всіх значущих особистостей угорської літератури, включаючи угорських авторів, що мешкали за кордоном.

Уряд Кадара усвідомлював пропагандистські можливості жартівливого сатиричного журналу, особливо якщо він також публікує смішні карикатури. Тому після поразки революції 1956 p. Ludas Matyit був одним із перших, хто був поновлений у лютому 1957 року. До видання часопису були залучені кращі художники-карикатуристи Угорщини, вони розірвали з практикою, яка існувала раніше, а саме відкритою агітацією без будьякого гумору, і замінили іiі більш стриманою іронією, тонким гумором та у дозволених межах сатирою. Навіть у 70-ті можна було лише жартувати над діяльністю побутових підприємств, комунального транспорту, радіо й телебачення.

5 січня 1957 р. побачило світ молодіжне видання - тижневик Magyar Ifj usag. Воно виходило спочатку під егідою Угорської революційної молодіжної асоціації робітників, потім Угорської комуністичної молодіжної спілки (УКМС). До речі, спілка видавала дев'ять газет, кілька з яких мали понад 100000 примірників (наприклад, Fules, Pajtas), а також мала власну видавничу компанію (Ifj usagi Lapkiado Vallalat). У редакціях більшості газет діяли не лише партійні організації, а й організації УКМС. На своєму засіданні 25 серпня 1972 р. Центральний комітет Спілки 
так визначив роль молодіжної преси: «Молодіжна преса по суті повинна виконувати завдання партії. Насамперед соціалістичне виховання молоді; вивчення специфічних потреб молоді; підтримка роботи соціальних органів та установ, які відіграють ключову роль у вихованні молоді й орієнтуванні на громадські потреби. Наша преса по суті відповідає цим трьом вимогам, зокрема Magyar Ifj usag, Pajtas, Ifj ukommunista, Uttorovezeto, Ifj usagi Magazin, Vilag Ifj показують значні результати в цьому відношенні» [22].

Після поразки революції керівництво партії заборонило видавати католицькі газети на пів року. У своїй резолюції від березня 1957 р. Тимчасовий центральний комітет Угорської соціалістичної робітничої партії зазначав: «Виходячи з досвіду, заходи повинні бути спрямовані на ізоляцію католицької церкви як головного представника церковної реакції в Угорщині від більш лояльних церков». Тому пропозиція про дозвіл церковних газет була затверджена Наглядовим комітетом з поправкою, що поки що неможливо видавати газети католицької церкви.

Пізніше, дві газети католицької церкви отримали ліцензію на видання часописів після 1956 року: Uj Ember es a Kereszt та Katolikus Szo. Вони обидві були під пильним цензурним контролем. Uj Ember es a Kereszt була під особливо жорстокою цензуpoю. Katolikus Szo стала газетою руху «Священник світу», щоб продемонструвати існуючій диктатурі свою вірність [23].

У 1957 році розпочали свою роботу журнали Reformatusok Lapja, Evangelikus Elet, Uj Elet.

Однією з особливостей новітньої та культурної історії Угорщини є те, що з соціальних причин угорська література стала надзвичайно публічною i, відповідно, відігравала політичну роль у суспільстві. Багато членів письменницької спільноти прагнули брати участь у формуванні долі країни. Тому лідери УСРП приділяли особливу увагу літературній політиці. Керівники партії тримали під постійним контролем ці питання. Жодна інша сфера мистецького життя (кіно, театр, образотворче мистецтво, музика) не викликала такого інтересу в комуністичних лідерів. Діячі літератури перебували під постійним наглядом і їх намагалися перетворити на пропагандистів системи [24]. 
Тому існувала якась ідеологічна ідентичність між авторами, зібраними навколо певних редакцій журналів. Окрім того, вони змогли формувати позитивне сприйняття читачами соціальноекономічного життя в країні. На це, звичайно, була спрямована культурна політика, яку проводив ідеолог партії Дьордь Ацил. Партійні функціонери, відповідно, розробляли свою стратегію і суворо ревізували журнали.

Секретні служби, Спілки письменників (організація угорських письменників також була організована за зразком Спілки радянських письменників, заснованої Сталіним), а також письменницькі партійні організації постійно перевіряли письменників і поетів. Хто бажав співпрацювати з ними, отримував конкретний зиск. Їх книги виходили у значній кількості, журнали, щотижневики, щоденники регулярно публікували їх праці, вони отримували добре оплачувану роботу, їм регулярно надавали роялті та інші пільги, щоб вони могли придбати собі елітні вілли та жити як нові багачі. У період з 1945 по 1955 рр. твори Бели Іллаша були опубліковані тиражем у два мільйони (!) екземплярів (на відміну від Дежо Костолані та Міхая Бабіча, яких зовсім не публікували). Продажні літератори забезпечувалися безкоштовним житлом, без черги могли придбати автомобіль, встановити телефон.

Відповідно до марксистсько-ленінської теорії літератури, завдання письменника в капіталістичному суспільстві полягає в критиці існуючого ладу та пропагуванні успіхів соціалізму. Цей стиль мав три основні риси:

1) партійність: розбиття стратегії партії на тактичні (щоденні політичні) завдання (це було зроблено посиланням на статтю, написану Леніним у 1905 р.);

2) ідеалізм: який вимагав представлення дидактично розміщених постатей героїв, які представляють «соціальний прогрес» (позитивний герой);

3) висвітлення народу: що означало поєднання пролетарського стилю, з одного боку, та національного характеру - 3 іншого. Ця вимога виникла від Сталіна, який у своєму чіткому формулюванні схвалював літературу «національну за своєю формою, соціалістичну за своїм змістом». 
Щодо літературної форми, то тут головною стала вимога про те, що зміст повинен відображати актуальні теми, визначені партією, з пропагандистським забарвленням та повнотою аргументів.

При соціалізмі успішність письменників і поетів оцінювалася не степенем їх таланту, а відповідно до міркувань літературної політики, і від цього залежала кількість примірників книг, у яких друкувалися їх праці. Вартість видання журналів та літературних щотижневих газет була надзвичайно високою. У 1988 році на випуск було витрачено у мільйонах форинтів у рік на Elet es Irodalom - 6,3; Kortars - 7,5; Mozgo Vilag - 8,6; Nagyvilag - 9,7; Uj Iras - 5,2; Uj Tukor - 5,1 [25].

Kortárs - літературно-критичний журнал, був відновлений восени 1957 року після майже річної перерви. Його редагування було доручено двом надійним, з позиції влади, культурним політикам Йожефу Дарвашу та Габору Тольнаю, які також намагалися відповідати вимогам якості й лояльності партії при впорядкуванні першого випуску. Їх вступна стаття сповнена хибного оптимізму: помилки минулого були виправлені партією, письменники перейшли ближче до соціалізму, абстрактне замінено реальною літературною політикою [26].

У першому номері був надрукований відкритий лист, в якому шість письменників: Ласло Бенямін, Шандор Ордей, Лайош Коня Іштван, Дюула Шіпош і Лайош Тамаші - визнали провідну роль партії: «Ми для себе усвідомили, що письменник може розповісти правду про життя лише як письменник одного зі своїх історично визначених прогресивних класів, а його клас може бути лише частиною всього народу».

Журнал також надав простір для раніше замовчуваних письменників Яноша Кодолані, Ласло Немета. Крім творів відомих письменників, наприклад: Йожефа Дарваша, Золтана Джекелі, Дьордя Ронай, Пала Сабо, Арона Тамаші, Петера Вереша, були і представники молодших поколінь: Шандор Чоорі, Міклош Месой, Ласло Нодь, Надьєш Агнеш, Шаркаді Імре. Крім творів художньої літератури, студій, нарисів та критики, журнал публікував також соціографічні праці, а також звіти про помітні події в театрі, кіно, музиці та образотворчому мистецтві. Дюла 
Іллієс писав у одній зі своїх програмних статей про місце та роль Kortars у той період: «Я хотів би, щоб Kortars був наступником великих угорських журналів з історичною роллю, щоб ви могли побачити ясніше наше майбутнє».

Uj Iras - це літературний, мистецький та критичний журнал, започаткований у 1961 році. Він, головним чином, узявся публікувати нову угорську літературу, але вона також включала теоретико-публіцистичні твори, нариси, дослідження, критику та дискусії, що становлять суспільний інтерес. 3 критичного розділу читач зміг дізнатися не лише про твори художньої літератури, а й про твори мистецтва, театру, кіно, образотворчого мистецтва та телебачення. Свого часу це був якісний і читабельний часопис, який завжди мав грамотних, видатних редакторів. Uj Iras не мав практично сутичок з владою. Найбільший скандал спалахнув у зв'язку з новелою «Подорож» Іштвана Чісара, яка з'явилася у номері за березень 1972 року. Молодий письменник, розповідаючи про свій досвід подорожей, наважився глузувати з радянського телебачення та зі Спілки письменників Радянського Союзу. Головний редактор отримав за цей випадок письмове попередження.Журнал Nagyvilag висвітлював новинки світової літератури, був опублікований восени 1956 р. як часопис Спілки письменників Угорщини. Однак його наступний випуск міг з'явитися лише через пів року, в квітні 1957 року. 3 розпуском Спілки письменників редакція також була реорганізована. Еміль Градп'єр вважався недостатньо надійним, тому Ласло Гереблеш став новим головним редактором. Значення Nagyvilag полягало в тому, що він дещо згладив відчуження Угорщини від світової літератури, відкрив вікно у «великий світ». Він не тільки передав сенс життя та світогляду людей інших країн, але й створив основу для порівняння та запустив повільний процес бродіння у суспільстві. Редакція опублікувала високоякісні літературні твори, багато з яких не служили пропагандистським цілям.

Були чудові провінційні журнали по всій країні: у Дебрецені, Бекешчабі, Сегеді, Великій рівнині, Новій Аврорі, Тисатаї, Кечкеметі, Форрасі, Печі, Єленкорі, Сомбатхеї, у Дьорі.

4 квітня 1975 року угорський мутант багатомовного журна- 
лу «Радянська література» був запущений в Угорщині завдяки співпраці Міністерства культури Угорської Народної Республіки та Спілки радянських письменників. Вступне привітальне слово до першого номеру часопису написав Янош Кадар.

Mozgo Vilag, започаткований у 1971 році, - це журнал молодих письменників і художників, опублікований під підзаголовком «літературний, художній, громадський культурнокритичний журнал». Журнал названий на честь поеми Дюул Ілліеса Mozgo pasaulis, опублікованої в 1965 році. 3 грудня 1975 року періодичний випуск молодих письменників та художників виходив як щомісячний журнал. Він створив форум для початківців, молодих художників, публіцистів і народних педагогів.

Його редакторами був Міклош Верешш, молодий письменник із провінції, а потім Ференц Кулін, талановитий історик літератури з Будапешта. Талановита редакція зробила те, що мала зробити: вона опублікувала твори нового, молодого покоління, зі священною вірою, що це також демократизує систему.

У першій половині 80-х років Mozgo Vilag потрапив під адміністративний каток. Головного редактора Міклоша Верешша звинувачували у публікації дослідження філології та вірша Каролі Алекши, в якому він аналізував піонерську пісню, написану для товариша Ракоші. Редакція також отримала догану за те, що була опублікована збірка міського фольклору Агнеша Гая. Однак директор Університетської друкарні розірвав контракт $з$ журналом наприкінці 1980 р., мотивуючи це тим, що «друкарі відмовилися зняти 3 друку новелу Петера Гайноці «Стимул стихії» [27]. Випуск за березень.

Головний редактор подав у відставку через несправедливі гоніння, але влада і далі мстилася його наступникам. У березні 1981 року черговий номер Mozgo Vilag був знищений. Можна лише здогадуватися, що причиною став щоденник Яноша Геці або щоденник подорожі Міклоша Шюкшода до Польщі. У 1983 році влада діяла вже більш рішуче. Разом з головним редактором Ференцем Куліним була замінена вся редакція, а журнал заборонений. Нарешті, Юліана Сюч, яка стала новим головним редактором журналу, вирішила врятувати журнал, незважаючи на те, що частина угорської інтелігенції бойкотувала часопис, 
поновила його роботу. Однак і тут на заваді стало запровадження механізму цензури, 15 тисяч примірників номера серпня 1984 року були вилучені через дослідження, присвячені Троцькому.

Керівництво партії також вживало заходів проти угорськомовної газети Uj Symposion у Воєводині (Югославія), що надала можливості для публікації угорських опозиціонерів. Заступник міністра закордонних справ Іштван Рошка подав ноту протесту до посольства Югославії в Будапшті, в результаті редакція на чолі з Яношом Сівері була розігнана.

Того ж року весняний номер журналу Liget також був закритий, оскільки в новелі Пала Бекеша про Олександра Дубчека першого секретаря Комуністичної партії Чехословацької Соціалістичної Республіки, ініціатора «Празької весни», що призвела до окупації країни 21 серпня 1968, - було зображено героєм.

Режим Кадара намагався привернути частину інтелігенції на свій бік, тому вони заснували журнал Valóság. Перший номер був опублікований наприкінці 1958 року. Журнал виходив кожні два місяці до кінця 1963 р. та щомісяця з початку 1964 р. офіційно під егідою Товариства розповсюдження наукових знань. Через свою суспільно-наукову спрямованість це видання довелося відокремити від теоретичного журналу Угорської соціалістичної робітничої партії Tarsadalmi Szemle. Valosag розпочався 3 п'ятдесяти тисяч примірників і став журналом, який мав найбільшу читацьку аудиторію.

Журнал Vigilia отримав дозвіл на видання в червні 1957 року. Незважаючи на те, що Дьордя Рунай, який у той час був одним із найпотужніших головних редакторів, звільнили без його згоди, він часопису допомагав виховувати християнську інтелігенцію, створити більш сучасний образ церкви та започаткувати форум для тих «буржуазних» письменників, чия творчість замовчувалася. Після повернення Дьорджі Руна (1969) Vigilia став найпрестижнішим органом інтелектуального і християнського життя. У ньому були опубліковані вірші Агнеш’ї Немеш Надь, Золтана Єкеї, Дьордя Рона, Яноша Пілінскі, Бели Кондора та Іштвана Шінка. Регулярно публікуються твори письменників: Івана Манді, Іштвана Фекете, Яноша Кодолані. 
УСРП, яка на чолі з Яношом Кадаром прийшла до влади в Угорщині у 1956 році та керувала країною до 1990 року, зуміла вивести державу з політичної та економічної кризи, перетворити ії̈ в найуспішнішу серед інших членів соціалістичного табору. Звичайно, у цьому угорцям допоміг СРСР, який надавав країні значну економічну та фінансову допомогу. Тільки за рахунок постачання дешевих нафти та газу Угорщина мала зиску 6 мільярдів доларів США щорічно.

Розпочинаючи з 1967 року, режим Кадара розпочав боротьбу 3 антисоціалістичними елементами, насамперед сконцентрувавши свої зусилля на пресі та літературі. Саме серед журналістів і письменників партія бачила своїх головних ворогів. Використовуючи метод «батога та пряника», партійним функціонерам на певний час вдалося зменшити протистояння з представниками творчої інтелігенції.

Але закрити рота всім не вдавалося. I час від часу в газетах, журналах з'являлися статті, в яких гостро критикувалася соціалістична дійсність, викривалися проблеми повсякденного життя угорського народу, висловлювалася незгода 3 політикою Радянського Союзу. За такі публікації звільняли з роботи головних редакторів, закривали видання.

Тим не менше, партії не вдалося зберегти монополію на правду, і рано чи пізно до пересічного угорця доходила правдива інформація, й урешті-решт народ Угорщини зробив свій вибір наприкінці 80-х років, змінивши політичний режим у країні.

\section{Література}

1. Illyés Gyula. Naplójegyzetek 1961-1972. Budapest: Szépirodalmi Könyvkiadó, 1989. 420 old.

2. Pozsgay Imre. 1989. Politikus-pálya a pártállamban és a rendszerváltásban. Budapest: Püski, 1993. 252 old.

3. Kis János. Donath Ferenc a magyar történelemben. Donath Ferenc: A Márciusi Fronttól Monorig. Szerkesztette: Szabó Judit, Valluch Tibor. Budapest: Századvég Kiadó, 1992. 313 old.

4. Ткач Д. Сучасна Угорщина в контексті суспільних трансформацій: Монографія. - К.: МАУП, 2004. - 480 с.

5. MOL Minisztertanácsi Tájékoztatási Hivatal XIX-A-24-b. 
6. Bernáth László: A MÚOSZ iskolája. Képzés a káosztól a rendig. Médiafüzetek, 2004/2. 56.

7. Szabó Miklós. Még néhány szó a magyar önépítésről. A Monori tanácskozás. 1985. Június 14-16. Szerkesztette: Rainer M. János. Budapest: 1956-os Intézet, 2005. 289 old.

8. Cseh Gergő Bendegúz - Kalmár Melinda - Pór Edit (szerk.): Zárt, bizalmas, számozott. Tájékoztatáspolitika és cenzúra 1956-1963. Budapest, Osiris, 1999. 218-219.

9. Szőnyei Tamás: Titkos írás: állambiztonsági szolgálat és irodalmi élet, 1956-1990. Budapest, Noran, 2012. 99.

10. Solt Pál (főszerk.): Iratok az igazságszolgáltatás történetéből I. Budapest, Közgazdasági és Jogi Könyvkiadó, 1992. 588-591

11. Zinner Tibor: A kádári megtorlás rendszere. Budapest, Hamvas Intézet, 2001. 167.

12. Bajomi Lázár Péter (szerk.): Magyar médiatörténet a késő Kádárkortól az ezredfordulóig. Budapest, Akadémia Kiadó, 2005. 57.

13. Várkonyi Péter (1931-2008), kommunista politikus, külügyminiszter

14. Cseh Gergő Bendegúz - Krahulcsány Zsolt - Müller Rolf Pór Edit (szerk.): Zárt, bizalmas, számozott. II. Irodalom-, sajtó- és tájékoztatáspolitika, 1962-1979. Dokumentumok. Budapest, Osiris, 2004. 205.

15. Szerencsés Károly: Eltékozolt évtized: adalékok a kádári hetvenes évek történetéhez. Budapest, Kairosz, 2010. 235.

16. Vörös László: Szigorúan ellenőrzött mondatok. A főszerkesztői értekezletek történetéből (1975-1986). Szeged, Tiszatáj Könyvek, 2004. 321.

17. Vásárhelyi Mária: Újságírók, sajtómunkások, napszámosok. Budapest, Új Mandátum, 1999. 33-34.

18. Bajomi-Lázár Péter: Médiapolitika. In: Bajomi Lázár i. m. (367. lj.) 26 .

19. Magyar Hírlap (1968-). Magyar médiatörténet blog (2014. nov. 30.) (Hozzáférés: 2018. szept. 14.)

20. Agnes Gulyas (1998). «Tabloid Newspapers in Post Communist Hungary». Journal of the European Institute for Communication and Culture. 5 (3): 65-77.

21. Vadas Zsuzsa: Tuti dilik. 50 év a sajtó körül. Budapest, Nők Lapja Mühely, 2007. 
22. Tomka Miklós: Vita a gyermek- és ifj úsági sajtóról. Jel-Kép, 1987/2.37.

23. Pál József: Békepapok. Katolikus békepapok Magyarországon, 1950-1989. Budapest, Egyházfórum, 1995.

24. Márai Sándor írásainak tükrében. Budapest, Helikon, 2006. 80-81.

25. Kortárs, 1957/1. 3-4.

26. Tolnai Gábor (1910-1990) irodalomtörténész, esszéíró, egyetemi tanár, az MTA tagja. 1953-1959 között az Irodalomtörténeti Közleményeket, 1957-1962 között a Kortárs címü folyóiratot is szerkesztette

27. L. Kiricsi Zoltán: «Szülőhazám téglái...» Illyés Gyula: Mozgó Világ címü verséről. Iskolakultúra, 2002/11 61 


\section{6. Журналістика Угорщини після зміни політичного режиму в кінці 80-х років}

Угорська «революція» 1989 року докорінно відрізнялася від подій у Чехословаччині, НДР і Румунії, де розрив з минулим був несподіваним і драматичним. Перехід до нової політичної системи в Угорщині став результатом мирного переговорного процесу, що розгорнувся в країні влітку 1989 року, механіка переходу визначалася докорінними змінами, які відбулися всередині правлячої Угорської соціалістичної робітничої партії (УСРП). Конфлікт між реформаторами з УСРП і демократичною опозицією не носив ідеологічного характеру, існувала згода щодо того, що суспільство й економіка Угорщини повинні бути трансформовані за моделлю розвинених ліберальних демократій за порівняно короткий проміжок часу, і при цьому слід виконувати рекомендації міжнародних фінансових організацій. Питання стояло про те, хто очолить процес перетворень. Таким чином, технократи-прагматики на чолі з прем'єр-міністром Міклошем Неметом, що займали ключові позиції, відмовилися від комуністичних догм і відкрито пішли на демократизацію [1; 2].

Угорські лідери в 1988 і 1989 роках докладно консультувалися з іспанськими лідерами про те, як встановлювати демократію, в квітні 1989 року до Будапешта в якості радників прибула іспанська делегація [3].

Спостерігачі одразу побачили схожість 3 демократизацією в Іспанії [4]. Угорщина досягла певних результатів від довготривалих економічних реформ і обмеженої політичної лібералізації в 1980-і роки, проте значні перетворення відбулися тільки після відставки Яноша Кадара з поста генерального секретаря УСРП на партійній конференції в травні 1988 року. Новий генсек Ка- 
рой Грос, який керував економічною реформою на посаді голови уряду і виступав за плюралізм у рамках однопартійної системи, спочатку сприймався прихильником досить радикальних перетворень у порівнянні з прихильниками збереження режиму в незмінному вигляді. Однак, усередині партії зміцнювалося реформаторське крило, представники якого були обрані на партійній конференції до складу політбюро: Режьо Ньєрш, колишній (1940-і роки) член Соціал-демократичної партії Угорщини і депутат від неї в Державних зборах, а в 1960-і - 1970-і роки керував проведенням економічної реформи на посаді секретаря ЦК УСРП; секретар ЦК Міклош Немет, який вивчав економіку не тільки в Університеті економічних наук ім. Карла Маркса, але і в Гарварді; переконаний прихильник демократизації Імре Пожгаi [5].

Усередині партії виникли «гуртки реформ», незабаром об'єдналися в Союз реформ і Народно-демократичну платформу [6].

У листопаді 1988 року Немет змінив Гроса на посаді голови уряду. Національна опозиція у вересні 1987 року заснувала Угорський демократичний форум (УДФ). Ліберально налаштовані студенти в березні 1988 року створили Альянс молодих демократів (більш відомий під угорською назвою Фідес). Як демократична опозиція владі, у листопаді 1988 року був сформований Союз вільних демократів (СВД). Однак, навесні 1989 року ці організації втратили серйозний вплив, почали шукати і знайшли опір у демократичних груп та лідерів усередині УСРП: УДФ у І. Пожгаі, СВД - у партійних реформаторів, які об'єдналися навколо Р. Ньєрш.

22 березня 1989 року 8 опозиційних організацій (УДФ, СВД, Фідес, відтворені партії: Незалежна партія дрібних господарів, Соціал-демократична партія Угорщини та ін.) створили своє об'єднання «Опозиційний круглий стіл». Пізніше в нього ввійшла Християнсько-демократична народна партія. Найбільшим впливом у ОКС користувався Угорський демократичний форум. На ініційовану УСРП нараду з громадськістю, пріоритетною темою якого була розробка нової конституції, був запрошений ОКС поряд 3 традиційно близькими до комуністів профспілка- 
ми, молодіжними, жіночими й іншими громадськими організаціями.

Розгорнувся навесні процес переговорів між УСРП і ОКС, який проходив поетапно: підготовка двосторонніх переговорів, їх проведення, що почалися 13 червня та отримали офіційне найменування Національний круглий стіл, тристоронні переговори (за участю сателітів УСРП, що не відіграли помітну роль).

18 вересня на останньому засіданні Національного круглого столу організації-учасники (крім СВД і Фідес) підписали підсумкову угоду про створення основ парламентської демократії та звернулися до глави уряду з проханням винести підготовлені поправки до законів на затвердження парламенту. Питання, про які не вдалося домовитися, були винесені в листопаді на референдум.

У жовтні 1989 року ВСРП провела свій останній з’їзд, на ньому переважали представники Союзу реформ і Народнодемократичної платформи. Партія перетворилася в Угорську соціалістичну партію (УСП), яка посіла соціал-демократичні позиції. Головою ВСП був обраний Режьо Ньєрш.

Парламент на сесії з 16 по 20 жовтня ухвалив закон, який передбачав багатопартійні парламентські вибори й прямі президентські вибори. ВНР була перетворена в Угорську Республіку, в їі конституції гарантувалися права людини і громадянина, а також була створена організаційна структура, що забезпечила поділ повноважень між судовою, законодавчою і виконавчою владою.

На референдумі, що відбувся 26 листопада 1989 року виборці схвалили обрання президента після парламентських виборів, необхідність звіту правлячої партії про свою власність, припинення діяльності партійних осередків на виробництві, розпуск робочої міліції.

Навесні 1990 року відбулися перші вільні вибори, в результаті яких до влади прийшла опозиція на чолі УДФ. У період з 12 березня 1990 року по 19 червня 1991 року радянські війська були виведені з території Угорщини [7].

Революція спочатку відбулася у 1988 році в угорських 3МI, яка випередила революційні зміни в угорському суспільстві, що 
призвели до зміни моделі суспільно-політичної системи суспільства.

По-перше, Всеугорська партійна конференція, яка відбулася в травні 1989 року, взяла курс на широкі реформи у внутрішньополітичному житті країни, що зачіпають ідеологічні, економічні, соціальні та морально-етичні аспекти, всі основоположні питання угорської держави, курс на оновлення політичних інститутів суспільства.

По-друге, незважаючи на кадрові перестановки в партії й уряді, прихід нових людей до керівництва і трансформацію в УСРП, погіршилися настрої в суспільстві, що пов'язано 3 політичною та економічною нестабільністю, помітно впав авторитет УСРП, профспілок (численність партії скоротилася на 62 тис. осіб, скорочення членства в профспілках оцінювалося в 6-7\% - вихід з цих організацій прийняв масовий характер, очевидною стали суспільна напруга, падіння життєвого рівня, економічна і політична криза, явища націоналізму, тенденція до перегляду оцінок щодо подій 1956 року.

По-третє, в 1988 році ясно відчувалося, що довіра до партії й уряду похитнулася, оскільки вони не знайшли шляхів виходу з ситуації, яка склалася, відчувалася криза влади.

По-четверте, суспільно-політичне життя в Угорщині вже в 1988 році характеризувалося наявністю всіляких альтернативних об’єднань і партій, що починали здійснювати відчутний i все більш зростаючий вплив на угорське суспільство, використовуючи всі можливі засоби масової інформації (включаючи друк, радіо, телебачення) для викладу своїх політичних програм.

У 1989 році в країні налічувалося близько 50 великих альтернативних об'єднань, партій, громадських рухів, товариств, профспілок - і не зважати на це явище, яке стало політичною практикою, було вже неможливо.

Усі ці процеси проходили на тлі ослаблення партійнодержавного контролю над засобами масової комунікації.

Таким чином, усі перераховані моменти мали безпосередній вплив не діяльність засобів масової інформації і стали темами їхніх виступів - на відміну від попередніх років, коли негативні 
події в країні нерідко замовчувалися пресою. Саме з 1988 року діяльність 3МІ набула некерованого характеру (з боку влади) [8].

Провідні західні країни розуміли, що ЗМІ мають значний вплив на суспільну свідомість і тому з допомогою своїх спецслужб здійснили інформаційну експансію в країнах соціалістичного табору та розпочали цю діяльність саме з Угорщини.

Ці зусилля західних держав лягли в гарний грунт, саме в цей час в Угорщині значно ослаб партійно-державний контроль над засобами масової комунікації, а розпочинаючи з 1988 р., функціонування масмедіа стало незалежним від влади. У ЦК УСРП ліквідований сектор преси, а також відділ агітації та пропаганди, одним із головних завдань якого був контроль за діяльністю ЗМІ. Партія практично відмовилася від керівництва пресою. У медіасфері соціалісти зберегли керівництво тільки діяльністю свого центрального органу газети Népszabadság, а також партійними виданнями на місцях - органами обкомів партії.

Керівництво діяльністю радіо і телебачення, Угорського телеграфного агентства (MTI), а також газети «Magyar Hirlap» узяв на себе уряд. Скасовано Управління інформації при Раді міністрів УНР, замість якого створено Управління Ради міністрів, що закріпило за урядом функції видачі дозволу та реєстрації новостворюваних видань, розподіл ліміту на папір [9].

Істотні зміни в структуру 3МІ внесла поява нових численних видань. До моменту прийняття Закону про пресу (1986 рік) у країні функціонувало близько 1700 газет і журналів, за два роки з'явилося ще 13, а в 1988 р. - 85 нових видань. Це органи різних альтернативних об'єднань, партій - відкрито опозиційні видання. У 1988 році з'явилися нові видавництва різного штибу, створені на кошти акціонерних товариств, кооперативів, банків, видавництв, багатих угорських емігрантів із залученням іноземного капіталу [10].

Так, 15 жовтня було оголошено про створення в Будапешті спільного угорсько-американського видавництва зі статутним капіталом 15 млн форинтів для видання книг угорських автоpiв i журналу Hitel. Іншим прикладом створення змішаного підприємства з випуску газетно-журнальної періодики є установа видавництва Reform зі статутним капіталом 1 млн марок. 
Воно було утворено акціонерним товариством Reform спільно 3 західнонімецьким концерном Шпрингера та інформаційним агентством Ференца (ФРН) [11, с. 71-72].

На медіаринок активно зайшли іноземні інвестори. Так, більшістю акцій у безкоштовній газеті Metro, таблоїді Blikk i політичній газеті Népszabadság володіли Metro International, Ringier Kiado та B.V. Tabora - Ringier Kiado, Bertelsmann AG відповідно [12].

Політичний тижневик HVG на 75\% контролювався німецькою групою Westdeutsche Allgemeine Zeitungsverlag, WAZ [13].

Іноземний капітал проник також на регіональний газетний ринок в Угорщині. Сюди протягом 90-х років зайшли: Axel Springer Magyarorszdg, Voralbelger Medienhonse та Daily Mail Trust. Це досить потужні медіакомпанії з власними сучасними друкарнями, розгалуженою системою розподільчої логістики, а саме: розповсюдження, доставка медіапродукції, які активно вводять у дію інші можливості угорського медіаринку.

У 80-і роки в Угорщині завдяки політиці Яноша Кадара була запроваджена так звана «ліберальна форма комуністичного режиму». Це давало змогу ЗМІ країни публікувати матеріали, в яких піддавалися критиці політичні, економічні принципи соціалізму. Угорські журналісти балансували серед дозволеного, допустимого і забороненого. Більшість 3 них розуміли, що їх позиція не подобається Москві, але тим не менш вони іiї не змінювали і відстоювали демократичні принципи в пресі.

Цікавим $є$ той факт, що через кілька років після зміни режиму в Угорщині ситуація в масмедіа повернулася до колишньої практики, коли 3МІ (частіше опозиційні або критично налаштовані), піддавалися цензурі правлячою партією, іншими владними або комерційними угрупованнями. Це явище отримало назву італінізації або берлусконізації [14].

В угорському політикумі активно обговорювалася тема обмеження числа 3MI, які видаються за державний кошт або фінансуються громадськими організаціями. У фокусі уваги подій знаходилися літературно-публіцистичний щотижневик «Élet és Irodalom» і тижневий часопис про культуру «Új Tükor» [15]. Щодо часопису «Élet és Irodalom», то його засновники та влас- 
ники, Золтан Ковач, Іштван Ванча і Густав Медьєші, які є відомими в Угорщині інтелектуалами та мають власну позицію щодо суспільно-політичного ладу в країні, що відрізняється правдивістю і чесністю та не змінюється з приходом до влади будь-якої коаліції. Це створило цьому щотижневику популярність і довіру в середовищі інтелігенції, думаючої публіки. Тому цей часопис випадає 3 кола аналогічних угорських 3MI як прогресивний та неупереджений. Головний редактор «Élet és Irodalom» Золтан Ковач, який займає цю посаду з 1993 року, говорить, що навіть у соціалістичні часи їх видання старалося відстоювати власну думку, цьому сприяло те, що в колективі журналістів працювали інтелігентні професіонали [16].

Серед інших опозиційних 3МI, які відіграють значну роль в Угорщині, є такі, що використовують у своїй роботі старі методи, але перебудували їх з урахуванням сучасних вимог ринку. Поміж них варто назвати літературно-критичний журнал Kortárs, створений ще у 1957 році, - видається щомісяця у Будапешті. У цьому часописі друкувалися відомі угорські письменники, представники молодших поколінь. Окрім творів художньої літератури, есе, нарисів та критики, журнал публікує також соціологічні праці, відстежує помітні події в театрі, кіно, музиці та образотворчому мистецтві. Великий угорський письменник, поет, драматург, тричі лауреат премії Лаюша Кошута Дюла Іллеш писав у одній зі своїх програмних статей про місце та роль Kortárs: «Я хотів би, щоб Kortárs був спадкоємцем великих угорських журналістів і виконав свою історичну роль, а саме, щоб наші нащадки могли краще побачити майбутнє» [17].

Nagyvilág видавався Спілкою угорських письменників і був щомісячним журналом світової літератури. Перший його номер був опублікований у жовтні 1956 року. Публікація призупинена з січня 2016 року [18].

На шпальтах журналу друкувалися твори авторів з усього світу. Час від часу в часописі з'являлися статті з критикою соціалістичного ладу, але влада на це закривала очі. Політолог, відомий дослідник угорських 3MI, Петер Байомі-Лазар вважає, що до початку 90-х років журнал був своєрідним запобіжником для зниження суспільної напруги у середовищі інтелігенції [19]. 
У той же час, такі видання, як Világosság, Valoság, Társadalmi Szemle, Kritika за часів соціалізму займали провладну позицію й у своїх публікаціях на соціальні, історичні та політичні теми намагалися слідувати лінії партії.

Так, журнал Társadalmi Szemle, заснований у 1931 році, 3 1946 року поступово змінював назви заголовків рубрик, і вже у 1988 році у ньому можна було прочитати: дослідження, обмін думками, перебудова та соціальна політика, історія європейського фашизму, орієнтація, записки культурної політики, життєві шляхи - кооперативи, міжнародна перспектива, Свропа.

Видавався журнал щомісячно і був головним рупором УСРП. У 1998 році вийшов останній номер цього часопису [20].

В кінці 80-х років під впливом горбачовської перебудови в масмедіа Угорщини сталися докорінні зміни. На медіаринок вийшли нові політичні періодичні видання, які миттєво завоювали довіру читача. Якщо в соціалістичні часи ЗМІ доносили до публіки інформацію про суспільно-політичне, економічне становище в країні заполітизованою, стандартною мовою, то медіаполітику кінця 80 -х - початку 90 -х років відрізняють відкритість та неупередженість, гострота оцінок і думок.

Усе це сформувало попит на появу політичних періодичних видань, які б відповідали вимогам часу, задавали загальний тон журналістиці. Найбільш характерним зразком подібного періодичного видання $€$ часопис Reform. Це був перший незалежний журнал демократичних новин 3 новим духом і формою, який з'явився вперше на зорі зміни режиму та вийшов друком у вересні й до грудня 1988 року мав тираж 170 тис. примірників.

Він був створений як змішане підприємство 3 випуску газетно-журнальної періодики видавництва «Реформа» зі статутним капіталом один мільйон марок. Він був започаткований акціонерним товариством «Реформа» (спонсорами якого були 13 організацій, банків, у тому числі видавництва УСРП «Кошут» та «Хірлап», кредитний банк УНР) спільно з західнонімецьким концерном Шпрингера й інформаційним агентством Ференца (ФРН).

У своєму зверненні до підписників головний редактор часопису Петер Тьоке 23 вересня 1988 року писав: «Шановний 
читачу! Вперше за десятиліття ви тримаєте газету, яка називає себе, можливо, трохи скромно незалежним, демократичним журналом новин та вважає своїм обов'язком сприяти політичним, соціальним і економічним реформам. Дотримуючись кращих традицій угорської журналістики, тижневик «Реформа» прагне створити незалежний імідж та зобов'язується представити проблеми, які хвилюють їі людей, з якомога ширшого боку, зіткнувшись з думками та надаючи місця для дебатів у суспільстві. Ми сподіваємося, що своїми скромними засобами можемо сприяти розширенню суспільної гласності та просуванню чистоти суспільного життя» [21].

Безумовно, що серед часописів такого кшталту потрібно назвати Héti Világgazdaság або HVG. 3 часу свого заснування у 1979 р. став провідним економічним та політичним тижневиком Угорщини як з погляду тиражу, так і читацької аудиторії [22].

Будучи регулярним джерелом новин та інформації, HVG надає об'єктивну інформацію про внутрішню й міжнародну політику, економіку та суспільство. Спочатку своєї діяльності часопис був економічно орієнтований, але поступово розширив спектр статей і закріпив свою популярність за рахунок оглядів внутрішньої та міжнародної політики з реформістських позицій.

Далі варто згадати тижневик 168 Ora, який з'явився на угорському медіаринку в 1989 році. На початковому етапі своєї діяльності це була тільки версія для друку програми радіо, а пізніше він став політичним виданням.

168 ORA публікувалася щотижня по четвергах і пропонувала статті про політику та поточні справи, а також містила інтерв’ю з відомими громадськими діячами. Журнал мав ліберальну і ліву ліберальну позиції. Журнал пропонував себе в якості важливого суспільного, інтелектуального тижневика.

Серед знакових прикладів сучасної угорської журналістики варто назвати щотижневик Heti Válasz, заснований з ініціативи першого уряду Орбана у 2001 році. Публікувався журнал щотижня по четвергах, штаб-квартира знаходилася в Будапешті. Журнал висвітлював новини про політику, економіку і культуру, стояв на консервативній позиції. 3 моменту свого створен- 
ня у журналу були різні власники. У 2010 році власником було спільне підприємство, засноване за допомогою угорського медіапідприємця та політика Тамаша Феллегі та датської венчурної компанії DEFAP. Головний редактор часопису Габор Борокай був керівником пресслужби лідера Фідес Віктора Орбана в 1998-2002 pp.

Часопис Heti Válasz припинив випуск своєї друкованої верciї в червні 2018 року, опинившись, згідно із заявою видавців, на межі банкрутства. У серпні того ж року була закрита й онлайнверсія видання, а редакція - розпущена. Газета входила до медіаімперії олігарха Лайоша Шімічки. Раніше Шімічка був тісним соратником прем'єр-міністра Угорщини Віктора Орбана, однак, пересварившись $з$ ним, почав фінансувати незалежні 3МI консервативного спрямування. Heti Válasz була єдиним консервативним 3МI, що дозволяв собі критику на адресу правоконсервативного уряду Орбана.

Серед впливових журналів, які заявили про себе після зміни режиму, варто назвати часопис Hitel. 15 жовтня було оголошено про початок його виходу з листопада 1988 року як органу Угорського демократичного форуму (УДФ). Однак, 3 листопада, інформуючи про пресконференцію, організовану цим журналом, угорська преса повідомила, що, за словами його головного редактора, Hitel нічого спільного не буде мати з УДФ, а буде демократичним незалежним виданням з накладом 20 тис. примірників (у грудні його тираж становив уже 39 тис. примірників) i періодичністю двічі на місяць.

Заснував журнал невеликий кооператив «ICIC» (без будьякої фінансової участі держави) на комерційній основі за участю західного капіталу, кошти на Hitel у розмірі двох мільйонів форинтів виділив угорський винахідник-підприємець Ф. Морваї. Це видання було самостійним у політичному й економічному відношеннях, відповідальність за його діяльність ніс головний редактор.

3 вересня 1992 року - Hitel виходив щомісяця та став одним iз найпопулярніших літературних форумів за останні десятиліття. Його читачі - в основному творча інтелігенція та науковці [23]. 
Серед угорських ЗМІ на особливу увагу заслуговує часопис Magyar Narancs. Створений у 1989 року як журнал для молоді, близький до партії Фідес, ліберально налаштований, прозахідний та проринковий політико-культурний щотижневик. Дослідники масмедіа відносять його до яскравого прикладу гонзожурналістики. Його основний профіль - права людини, включаючи захист прав національних меншин, а культурний напрям зачіпає як високу, так і популярну, мейнстримну та авангардну культуру.

Читачі часопису представляють міських, ліберальних, висококультурних споживачів у віці від 29 до 40 років, які в основному цікавляться вищою політикою і мають післяуніверситетську освіту. Близько однієї п'ятої з них - передплатники, решта читачів купують журнал на вулиці. Крім того, вебсайт видання має 2-3 тисячі індивідуальних відвідувачів. Статистика також показує, що кількість переглядів сторінок показує більше 10000 відвідувачів щодня [24].

У перехідний період поряд з журналами, про які йшла мова вище, в медійному просторі Угорщини значну роль відігравали газети. Хоча через економічні труднощі частина державних періодичних видань змушені були припинити свою діяльність, на їх місце прийшли нові, амбітні та агресивні гравці медіаринку.

Разом 3 тим, намітилася стійка тенденція зниження тиражів і популярності центральних газет, окрім «Мадяр хірлап» і «Мадяр Немзет», тираж яких зріс на 11,6 і 26,7\% відповідно. Згідно $з$ даними журналу «Шайто Тер'єстеш», за 1988 рік партійна «Непсабадшаг» втратила 32,7\%, профспілкова «Непсава» - 26,5, міська вечірня «Ешті хірлап» - 27,4 і навіть спортивна «Непшпорт»-23,1. У той же час, тиражі новостворених комерційних видань зростали [25].

До цього часу вже застарів прийнятий усього двома роками раніше Закон про пресу, так як соціально-економічна ситуація в країні значно змінилася. Тому на засіданні Політбюро ЦК УСРП 15 листопада, розглянувши підсумки його виконання і 3 огляду на те, що з 1989 року вступлять нові закони, які не відповідають Закону про пресу, визнало, що уряду необхідно під- 
готувати новий закон - про інформацію, який прийде на зміну Закону про пресу і надасть правові гарантії та визначить норми свободи друку, громадського інформування [26].

Ще однією важливою особливістю засобів масової інформації Угорщини в 1988 році стала зміна змісту діяльності преси, зміна оцінок, концепцій з низки питань, прагнення відобразити дійсність з різних боків, поглядів, відсутність «заборонених» тем. Однак, нерідко це призводило до результату, прямо протилежного: замість максимально об'єктивного погляду висловлювалися крайні погляди, які часто спотворювали дійсність і збентежували людей без причини. Публікація в деяких виданнях неперевірених повідомлень, неточностей, «жовтих качок», чуток була або часом навмисною, а іноді готувалася як провокаційна інформація. Цим в основному «грішили» новіші видання. У цей час значно спростилася процедура дозволу на видання нового друкованого органу, для цього необхідна була лише його формальна реєстрація - необхідно було лише повідомити в Управління Ради Міністрів про свій намір випускати газету (тижневик, журнал), офіційно їі зареєструвати й отримати в цьому Управлінні дозвіл (на практиці не було жодної відмови в реєстрації).

Разом 3 тим в країні виходив ряд періодичних видань, офіційно не зареєстрованих, але і не заборонених. Серед них, згідно 3 даними щотижневика «Refarm» (який через відсутність офіціальної реєстрації та засобів для видання назвав таку періодику самвидавом): щоквартальний орган Союзу вільних демократів Beszélő з тиражем 4 тис. екземплярів, незалежний щомісячник Demokrat, що випускався видавництвом АВС тиражем 1-3 тис. примірників, літературний щоквартальник Égtájak Között» 3 тиражем 200-300 примірників, щомісячники Hian 3 тиражем 10-15 тис. примірників i Fidesz hírek 3 тиражем 4 тис. екземплярів [27].

Подією став вихід угорською мовою тижневика «Московські новини». Його тираж для Угорщини був явно замалий близько 15 тис. примірників - тільки-но з'явився в газетних кіосках, він відразу ж розкуповувався, ставши справжнім дефіцитом. Це було пов'язано насамперед 3 тим, що ця газета чесно та 
відкрито повідомляла про події в Радянському Союзі, сміливо критикувала керівництво країни [28].

Таким чином, ми бачимо, що в певному сенсі угорська масмедіа підготувала перехід країни до багатопартійності.

Цікавим є той факт, що найвпливовіші щоденні газети соціалістичних часів і в нову добу зберегли свою читацьку аудиторію та залишилися на плаву. Мова йде про чотири найбільших видання, які стоять на протилежних позиціях у найрізноманітніших соціально-політичних і гуманітарних питаннях. На медіарінку Угорщини провідне місце багато років поспіль займала газета Népszabadság, яка намагалася пристосуватися до нових умов, що постійно змінювалися, як у суспільному житті, так і в структурі й характері преси.

По-перше, будучи центральним органом ЦК УСРП, газета прагнула ширше інформувати читачів про всі партійні форуми та заходи, внутрішньопартійні дискусії.

По-друге, залишаючись офіціозом, з появою альтернативних об'єднань і альтернативного друку газета втрачала своє виняткове право на єдину та безапеляційну думку з будь-якого питання.

По-третє, Népszabadság намагалася хоча б зберегти своїх читачів у нових умовах конкуренції, тому можна говорити, що газета прагнула знайти своє обличчя у мінливому світі. Згідно 3 даними «незалежного» тижневика Peform газета позиціонувалася як лівоцентристська [29].

Після падіння соціалістичного ладу газета була приватизована; власниками стали німецький концерн Bertelsmann AG (50\%), Фонд вільної преси (Szabad Sajtó Alapítvány) при Угорській соціалістичній партії (УСП) (26\%), Перший угорський інвестиційний фонд (16.8\%) і редакційна колегія (6\%).

У 2005 році газета була придбана компанією Ringier. У 2014 році після того, як угорське антимонопольне відомство попередило поглинання Ringier концерном Акселя Шпрингера, вона була продана Vienna Capital Partners. ВСП продала свої акції в Mediaworks, створений VCP компанії-посередника в 2015 році [30].

Газета була близька до коаліції УСП та Союзу вільних демо- 
кратів, хоча часом критикувала їх уряд. У міжнародних питаннях, як правило, підтримувала політику СС і США, однак час від часу виступала з критикою ініціатив Президента США Джорджа Буша-молодшого через політику «демократії на експорт».

Газета була раптово закрита їі власником Mediaworks 8 жовтня 2016 року. Журналісти готувалися до переїзду в новий офіс, проте, коли вони покинули свої старі кабінети, їх не впустили на нове місце роботи, повідомивши про припинення випуску видання і зупинку сайту. Mediaworks оголосила про те, що закриття було бізнес-рішенням через фінансові збитки газети.

Реальною причиною закриття ЗМІ був тиск з боку правлячої партії «Фідес». Усупереч твердженням власників про нерентабельність якраз за останній рік газета вийшла зі збитків і принесла прибуток у розмірі 130 млн форинтів (480 000 доларів США) [31].

25 жовтня 2016 року стало відомо, що газету придбав (i закрив) близький до Віктора Орбана угорський олігарх Лоренц Месарош, член партії «Фідес» і один з найбагатших людей країни. На протест проти закриття газети зібралися тисячі людей.

y Népszabadság був найбільший тираж з угорських видань до 2002 року, коли iï обійшли бульварний таблоїд Blikk i безкоштовна газета Metropol. Так, ще за часів УНР iï щоденний наклад становив 800 тисяч примірників (1973), на 1989 рік - 460 тисяч, але потім поступово знижувався, в 2016 році - 37 тисяч. Незважаючи на це, іiі тираж залишався вище, ніж у всіх інших угорських політичних видань. Таким чином, під час режиму прем’єр-міністра Віктора Орбана і його правоконсервативної партії «Фідес» вона була найбільшою опозиційною газетою.

Друга за значенням в Угорщині газета Magyar Nemzet була заснована в 1938 році Шандором Петьо і Дьюлою Хегедюш, угорськими журналістами журналу «Magyarság». 3 перших днів своєї діяльності вона стала популярним інформаційним форумом для протистояння німецькій окупації країни. У період Другої Світової війни газета була заборонена і повернулася до публікації в 1945 році. У післявоєнний період видавалася 3 перервами і нерегулярно, піддавалася цензурі й обмеженням, була змушена підтримувати офіційну позицію уряду. В той час 
Magyar Nemzet - це газета інтелігенції, яка відіграла важливу роль у висвітленні зовнішньополітичних і культурних новин.

У 1956 році газета була провідним друкованим органом народного повстання. У переломні роки 1988-1989 газета також відігравала важливу роль. Після розпаду соціалістичного блоку спочатку мала помірковано-консервативну спрямованість, а потім втратила своє колишнє значення. Газета зіткнулася з фінансовими труднощами і необхідністю приватизації. Видання постійно критикувалося за нестабільність та непослідовність у підтримці тієї чи тієї політичної лінії. У 1997 році газета і їі головний редактор були удостоєні премії «Magyar Örökség Díjas».

У результаті злиття в 2000 році з газетою Új Magyarország видання стало більш радикального спрямування, Magyar Nemzet на політичній шкалі помітно зрушилася вправо. У 2010 році газета підтримує лінію офіційного уряду Угорщини. У 2015, після так званого «Угорського Дня Г», газета робить ставку на незалежну і нейтральну редакційну політику, слідуючи західним традиціям якісної журналістики.

Після того, як власник видання, медіамагнат Лайош Шімічка посварився з прем'єр-міністром Орбаном, політична орієнтація газети змінилася: Magyar Nemzet перетворилася в незалежну газету консервативного спрямування, яка опублікувала, в тому числі, й деякі вельми резонансні розслідування. Після повторної перемоги Орбана на виборах у квітні 2018-го року Лайош Шімічка припинив фінансування газети, i та була закрита. У 2019 році видання перезапускається в новому вигляді [32].

Наступною газетою 3 великою читацькою аудиторією $\epsilon$ «Magyar Hírlap», яка видається в Угорщині з 1968 року. До 1990-х років вона була офіційною щоденною газетою Ради Міністрів Угорської Народної Республіки. Після зміни в країні політичного режиму газета була приватизована, перетворившись в інформаційно-аналітичне, багатогранне, ліберальне видання. У 2000 році газету придбало видавництво «Ringier AG», відоме своїми таблоїдами, і наступні 4 роки газета публікувала на своїх сторінках різні плітки, сенсації та інші бульварні чутки. Зміна напрямку не була оцінена читачами «Magyar Hirlap», що призвело до іiі занепаду. Період між 2003 та 2006 роками був на- 
сиченим в історії часопису, в якому відбулися вирішальні зміни як економічні, так і з погляду ідеології та духовності. В історії преси не є безпрецедентним, коли змінюються приналежність органу, його місце на газетному ринку i, водночас, його цільова аудиторія. У випадку з МН такі зміни відбулися за дуже короткий час. Після трансформації режиму більшість часописів стали іноземними. Magyar Hírlap був власністю англійського Maxwell, потім Marquard, з квітня 2003 року - швейцарської видавничої компанії Ringier. Однак, у вересні 2005 року угорський підприємець Габор Селеш купив газету. Ідеологічно та політично значущі зміни, які відбулися в цей період, сталися переважно в 2006 році після цієї події. У 2006 році, розірвавши зі своєю колишньою ліберальною ідеєю та ставши консервативною, газета почала підтримувати провладну партію «Фідес», що робить і до сьогоднішнього дня. Після 2018 року основний напрям часопису консервативний та правий, а також антиглобалістський. Газета дотримується національно-патріотичної лінії, зачіпає безліч актуальних національних проблем Угорщини. Як у більшості газет сьогодні, кількість примірників зменшується. У 2014 році кількість екземплярів часопису була лише 8000 [33].

Népszava намагалася більше уваги приділяти профспілковому руху, дискусіям про незалежність профспілок, закликам до центральної влади 3 цього приводу, обгрунтуванню причин створення незалежних профспілкових організацій та питань, 3 ними пов'язаних, напруженості у сфері зайнятості, безробіття, введення допомоги у зв'язку з безробіттям, рівня життя, інфляціï, дискусіям про право на страйк як спосіб вирішення економічних питань. Так само, як профспілки стали відкрито і гостро вступати у суперечку щодо урядових рішень (насамперед у сфері рівня життя населення), так і газета стала гостріше, критичніше виступати $з$ низки питань. Згідно 3 даними «незалежного» тижневика «Реформа» газета позиціонувалася як «лівосталіністська». За часів соціалізму вважалася рупором угорських профспілок. Сьогодні газета проводить лінію, близьку до курсу Угорської соціалістичної партії (MSZP). В останні роки фінансове становище видання залишає бажати кращого, справа доходила до зміни власників. Після того, як у квітні 2018-го року 
була закрита газета Magyar Nemzet, Népszava залишилася єдиною незалежною від уряду щоденною газетою Угорщини. На відміну від журналістики, ідеологія не відіграє і не може відігравати роль у редагуванні новин, оскільки «новини є недоторканними, їх думка вільна». Джерелом переважної більшості новин є УТ, закордонні інформаційні агентства та Інтернет-джерела, газета також публікує незначну кількість власних новин. Одним із сильних боків Népszava $є$ те, що після відбору новин журналісти аналізують їх, роз'яснюючи, звідки вони виникли та як можуть вплинути на життя читача. Іншим нововведенням $\epsilon$ структурні зміни, які відбулися в 2003 році, внаслідок яких співвідношення тексту, зображення та інфографіки змістилися на користь останньої. Це було необхідно, оскільки в міру зміни читацьких звичок людям потрібно було якомога швидше передавати інформацію. Старий тип угорської журналістики цьому не відповідав, тобто переходив від нерелевантного до істинного. Tому, крім коротких, легко зрозумілих текстів у Népszava, вони також допомагають у швидкій інтерпретації з багатьма малюнками та інфографікою. Népszava також присутня в Інтернеті приблизно з 2000 року. Сьогодні близько 50000 людей читають іiї щодня. Цей інтерфейс - найшвидший спосіб дістатися до молодих читачів та читачів за кордоном. Nepszava.hu також доступний на мобільних телефонах, майже 15 відсотків відвідувачів читають газету на таких пристроях. До зміни режиму Népszava була профспілковою газетою, тому довгий час iï читали переважно люди праці, а потім, після зміни режиму, зі зміною думок про профспілки газета фактично втратила читацьку базу. Однак реальні зміни відбулися в основному після 1994 року, коли газета дуже лібералізувалася. Після трансформації можна сказати, що сьогодні читачі - це середній клас лівого спрямування з університетською освітою. Щодо тиражів, то у 2003 році було надруковано майже 40000 примірників газети. 3 цього 17-18 тисяч були придбані абонентами, а решта - розпродана на вулиці. У 2009 році в середньому продавалося 20000 примірників на день. У газети немає офіційного спонсора, тому Népszava підтримує себе за рахунок власних доходів. У 2019 році щоденний тираж часопису складав 19973 примірників, 3 
них 12791 - підписники [34]. Підбиваючи підсумки, дійсно як революцію можна охарактеризувати кардинальні зміни, що торкнулися угорської преси в другій половині 1988 року. 3 дієвим політичним плюралізмом, який швидше нагадував інформаційну вседозволеність, скасуванням партійного керівництва пресою, розгубленістю властей, появою альтернативної «незалежної» комерційної періодики ситуація в угорській пресі докорінно змінилася. У 1989 році лише продовжилися і вкоренилися процеси, основи яких були закладені в 1988 році, чому на діяльності засобів масової комунікації цього часу і було загострено увагу суспільства. Головною особливістю 1989 року стала ще більша свобода дій ЗМІ в умовах політичної конкуренції різних партій, форумів та об'єднань, виникнення значної кількості нових видань на комерційній основі, відкрите проникнення західного капіталу в сферу інформаційно-видавничої діяльності, акціонування існуючих газет і журналів і перші спроби їх купівлі міжнародними видавничими корпораціями. Таким чином, кардинальні зміни, які почалися в угорських засобах масової комунікації з другої половини 1988 року, продовжилися і в 1989 році, що повністю змінило як структуру преси, їі обличчя, так і ставлення до неї. Почала складатися тенденція до поділу періодики на «якісну» і «масову», серйозних змін зазнавали центральні видання, перебудовуючи свою роботу за принципом «газета товар». Поряд з утвердженням на ринку незалежних видань, що працювали на комерційній основі, з'явилася бульварна преса, «першою ластівкою» якої стала щоденна Маi nap. Зазначимо, що зміни, які відбулися в угорському суспільстві, зокрема і в усьому Східноєвропейському світі загалом, відбилися на розвитку та діяльності засобів масової комунікації. У 1989 році з продовженням розвалу соціалістичної влади в Угорщині, що почався в 1988 році, керівництво країни повністю випустило 3-під свого контролю засоби масової комунікації, надавши цей важливий засіб влади на відкуп як окремим політичним нуворишам усередині країни, які мали фінанси, так й іноземним магнатам преси та західному капіталу (в тому числі угорцям, які іммігрували $з$ країни після відомих подій 1956 року). Наслідком цього стала загальна анархія і вседозволеність, так вважали навіть 
фахівці Міжнародного інституту друку в Цюріху. Західні магнати преси не забарилися відкрити новий Ельдорадо, так як будьякий з грошима в той момент міг (і робив) в Угорщині практично все, що хотів. Наприклад, Мердок придбав 50\% акцій нових видань - тижневика Reform та щоденної газети Mai nap, а Максвелл - акції урядового органу - газети Magyar hírlap i став 31 березня 1990 року офіційним видавцем цієї газети. Розкол Угорської соціалістичної робітничої партії, що стався на з'їзді в жовтні 1989 року, і легальна, офіційна діяльність різних партій та об'єднань призвели до невизначеності, а потім до відсутності керівництва пресою, яка, в свою чергу, підготувала перехід до багатопартійності, зміни моделі державного устрою і нових побудованих уже на зовсім інших принципах - виборів до Державних зборів. Що стосується змісту діяльності ЗМІ у 1989 році, то рік почався з аналізу діяльності уряду, і очолював його Карой Грос. В інтерв'ю зі співробітником Інституту з вивчення громадської думки А. Бокорі урядова Magyar hírlap наводила peзультати проведеного опитування населення з оцінкою діяльності Ради Міністрів за останні 17 місяців: тільки половина респондентів була задоволена роботою уряду і висловлювала йому свою довіру [35]. 8 січня було повідомлено про значне підвищення цін на основні продукти харчування, товари, послуги, збільшення транспортних тарифів [36]. Двома днями пізніше Magyar hírlap присвятила передову статтю законопроєкту про право громадян на створення об'єднань, проведення мітингів і зборів. 11 січня цей документ був прийнятий на сесії Державних зборів. Закон про право на об'єднання надавав можливість утворення та діяльності політичних партій. Népszabadság інформувала про створення спільних підприємств, зокрема угорсько-датського спільного підприємства «Едмонт - Паннонія», яке буде займатися випуском друкованої продукції, виробництвом мультфільмів, прокатом відеофільмів [37]. У цей же час центральні газети, що втратили до третини своїх передплатників, надають свої сторінки керівникам різних політичних партій і об'єднань, немов змагаючись в опозиційності з появою нових незалежних комерційних видань. Разом з тим, Magyar hírlap публікує результати опитування, яке фактично провалилося, 
проведеного тижневиком Reform. 28 січня по угорському радіо прозвучало інтерв'ю Імре Пожгаі про роботу підкомісії ЦК УСРП з вивчення періоду в розвитку країни після визволення 1945 року. Це радіоінтерв’ю і проведена в лютому публікація самого документа в Társadalmi Szemle стали тим видимим «поворотним моментом», з якого почався вже ніким не приховуваний крах влади і системи, до суспільної свідомості від імені правлячої партії була виголошена нова доктрина, що заперечувала 40 років життя країни. Урочисте перепоховання декількома місяцями пізніше Імре Надя і його прихильників, реабілітація всіх учасників подій 1956 року стали демонстрацією сили опозиції, а всенародні похорони Яноша Кадара підвели останню риску під епохою, названою його ім'ям. Як сказав Імре Пожгаі кореспонденту угорського радіо, ще не здійснена політична реабілітація Імре Надя. Документи свідчать, що в політичній кризі 1954-56 років мав рацію Імре Надь. Однак, що стосується його ролі та діяльності в 1956 році, то дискусії навколо цього ще йдуть. На основі досліджень підкомісія вважає події 1956 року народним повстанням, повстанням проти олігархічної панівної форми, яка знищувала націю. При аналізі 1956 року необхідно повернутися до подій колишнього періоду, до прийнятої або насильно прийнятої моделі соціалізму, яка виявилася цілком помилковою. Необхідно навчитися жити в умовах наявності іншої або інших партій. УСРП не може і не хоче говорити, яка $з$ них стане важливим фактором політичного життя. Може бути, 3 ними будуть встановлені партнерські відносини, ті ж, хто не може прийняти коаліцію або партнерські відносини, відіграватимуть опозиційну роль. Щодо вивчення трьох останніх десятиліть, Імре Пожгаі заявив, що для цієї системи була характерна відсутність особистої і взагалі будь-якої відповідальності. Безсумнівно, що керівники того періоду несуть велику відповідальність за розвиток подій. Аналіз останніх десятиліть не повинен бути якимось ритуальним зведенням рахунків, його треба проводити відповідно до правил європейської цивілізації. Необхідно також проаналізувати, чому в період після травня 1988 року розвиток подій у країні сповільнився. Чому немає такої глибокої перебудови, необхідність в якій є в економіці, суспільній сфері 
[38]. Через два тижні Пленум ЦК УСРП прийняв рішення про перехід до багатопартійної системи, про що докладно писала Népszabadság, a Magyar hírlap присвятила цьому рішенню, назвавши його «історичним», редакційну статтю [39]. Оцінка діяльності засобів масової комунікації і ставлення до них влади прозвучали у виступі Міклоша Немета при відвідуванні ним XI району Будапешта. У зв'язку з критикою діяльності СМI з боку громадськості він зазначив, що «не вважає правильним оплакувати колишні методи керівництва через друк, радіо і телебачення. Будь-хто може відповісти на критику з боку преси, якщо вважає, що вона необгрунтована. Профспілкова Népszava опублікувала в березні інтерв'ю заступника директора Інституту світової економіки ВНР К. Печі під заголовком: «Бідність - економічна модель рівності». Всі засоби масової інформації докладно висвітлювали святкування 15 березня чергової річниці угорської народно-демократичної революції 1848 року, повідомляючи різні історичні подробиці й переоцінюючи події майже півторастолітньої давнини, а заодно - і 1919 року, тобто Угорської радянської республіки. У березні у пресі з'являються статті про можливий нейтралітет Угорщини, відповідно, і неучасті у військових союзах. Природно, мається на увазі вихід з Варшавського договору, хоча прямо про це ще нейдеться. «Népszabadság» друкує статтю Я. Береца - секретаря ЦК УСРП з ідеології, в якій він пише, що «починаючи з літа 1979 року народження, після першого радикального підвищення цін, члени партії інстинктивно відчули, а потім дізналися, що риторика партійної політики і дійсність усе більше розходяться одна з одною». Ця ж газета інформувала про звільнення від своїх обов'язків Ш. Лакоша (у зв'язку з виходом на пенсію) - головного редактора партійного журналу Partélet, який припиняє своє існування й призначення. I. Сердахей став головним редактором нового друкованого органу УСРП Uj forum, який виходитиме замість двох колишніх партійних dblfzm. У номері від 1 квітня Magyar hírlap помістила три статті, які заслуговують на увагу. У матеріалі «Думки про звільнення» опубліковані інтерв'ю завідувача відділом Інституту історії партії, історика К. Урбана, директора музею Військової академії М. Зріні, військового історика І. Елведі. В іншому 
матеріалі писалося про рішення про тимчасове перебування на території ВНР обмеженого контингенту радянських військ, яке мотивоване не внутрішньополітичним становищем Угорщини в кінці 1950-х років, а проводиться в той час політикою НАТО та необхідністю спільного захисту від можливої агресії. Ще один матеріал - інтерв'ю секретаря комісії з відновлення історичної справедливості А. Хегедюш у зв'язку з ексгумацією й упізнанням останків I. Надя. В останні 10-15 років, зазначалося в матеріалі, в Угорщині поступово створилася політико-економічна i моральна криза, якій не змогла перешкоджати більш сучасна, найкраща, в порівнянні з попереднім періодом, політична практика 1956-1987 років, оскільки застосовується модель, яка вичерпала свої резерви. Як показує досвід, часткові реформи не ведуть до стабільних результатів. Потрібно одночасне оновлення економіки, суспільства, духовно-моральних відносин, - говорилося в інтерв ю [40]. 40. «Чи існує небезпека громадського розриву?» - під таким заголовком Népszava опублікувала статтю, головний висновок якої: криза в країні стала реальністю вона знаходить своє продовження в економіці, ідеології, довірі до керівництва. Ключовим питанням, зазначалося в статті, є положення в економіці. Якщо рішення економічних проблем залежить від удосконалення системи політичних інститутів суспільства, то і політика реформ загалом приречена на провал, якщо не буде створена ефективна економіка [41]. У травні в 3МІ знайшли своє відображення «апаратні чистки»- майже 3 усіх міністерських постів були зняті прихильники Гроса. На зміну їм приходили такі ж реформатори-прагматики, як глава уряду Мiклош Немет. Головне завдання оновленого кабінету полягала в тому, щоб закласти основи нової дієвої суспільно-політичної та економічної системи до того, як стара буде повністю демонтована. Кабінет міністрів, наголошувалося в пресі, поступово перетворювався у вирішальну політичну силу. Дві головні події літа - перепоховання Імре Надя і його подальша реабілітація та відхід 3 життя Яноша Кадара - відбулися майже одночасно, всебічно активно висвітлювалися засобами масової комунікації, зі значною кількістю подробиць, історичними довідками, оприлюдненням різних документів і невідомих раніше фактів. Також 
багато уваги приділялося рівню життя, зростанню цін і безробіття, збільшенню злочинності, самогубств, розлучень. Усе активніше виступали в засобах масової інформації лідери альтернативних об'єднань і партій, відкривалися нові видання, а ті, що існували раніше, прагнули пристосуватися до нових умов. Усі тенденції 1988 року одержували свій активний розвиток. 23 жовтня 1989 був опублікований текст конституційних поправок, які - за безпосередньої участі уряду на чолі з Міклошем Неметом - зачіпали 80\% тексту Основного Закону. Таким чином, по суті, в країні була прийнята тимчасова конституція, що замінила Конституцію 1949 року [42]. Це означало, вказували 3МІ, що закладена законодавча база мирного переходу країни до ринкової економіки, багатопартійної системи. 23 жовтня - «знаменний» день у сучасній угорській історії - це дата початку трагічних подій 1956 року («контрреволюції», «народного повстання»). Цікава історична «випадковість» - 23 жовтня 1989 року теж відбулася революція - оголошено про створення Угорської республіки, що призвело врешті-решт до зміни моделі демократичної республіки замість «народної республіки». Фундаментальними принципами державного устрою Угорщини, згідно 3 тимчасовою конституцією, оголошувалися «громадянська демократія» $\mathrm{i}$ «демократичний соціалізм». Також було гарантовано дотримання громадянських свобод та прав людини, принципу багатопартійності, заборони на політичну монополію в однопартійній системі. У тимчасовій конституції затверджувалася необхідність вільного вибору такого уряду, який міг би висловлювати інтереси народу і нести пряму відповідальність перед ним поряд з уведенням принципу поділу влади. Також було скасовано інститут Президії - його замінила президентська адміністрація, яка обирається парламентом. Спікер Національних зборів Матьяш Сюрьош (який незабаром став тимчасовим президентом країни) оголосив про створення Угорської Республіки. Угорська Народна Республіка систему державного соціалізму скасувала де-факто і де-юре. Зміна моделі, або революція, відбулася зовсім мирно. Але не тихо: ЗМІ відіграли в цьому процесі чи не ключову роль. Сама ж Угорщина відіграла роль каталізатора, прискоривши розпад усього соціалістичного табору. 


\section{Література}

1.Ласло Контлер. История Венгрии. Тысячелетие в центре Европы = A History of Hungary: Millenium in Central Europe. - M.: Весь мир, 2002. - С. 612.

2. Дмитрий Травин, Отар Маргания. Глава 6. Венгрия: Малые шаги больших перемен // Европейская модернизация. Кн. 2. - М.: Neoclassic; Terra Fantastica; ACT, 2004.

3. Хантингтон $C$. Третья волна. Демократизация в конце $\mathrm{XX}$ века. - М.: РОССПЭН, 2003. - С. 140. - ISBN 5-8243-8754-2

4. Rupnik J. Hungary's Quiet Revolution // New Republic. 1989. November 20. P. 20; New York Times. 1989. April 16. P. E3.

5. Венгерская «переговорная революция» // История антикоммунистических революций конца XX века: Центральная и ЮгоВосточная Европа / Отв. ред. Ю. С. Новопашин. - М.: Наука, 2007. - ISBN 5-02-035521-6.

6. Артём Кречетников. Самая бархатная революция // ВBC

7. Переход Венгрии к демократии https://ru.wikipedia.org/wiki/ Переход_Венгрии_к демократии

8. Т.Ю. Пынина Роль средств массовой коммуникации Венгрии в 1988-1989 годах. file://C:/Users/dtkac/Downloads/14417-13883-1PB.pdf

9. T.Iý. Pynına. Rol sredstv massovo1 kommýnıkatsı v smene politichesko1 modelı obestva na primere deiatelnost1 vengerskih media v 1988-1989 gg. https://www.elibrary.ru/item.asp?id=26674366

10. Gálik Mihály-Halmai Gábor-Hirschler Richárd-Lázár Guy: A nyilvánosság rendszerváltása, Új Mandátum Könyvkiadó, Budapest, 1998.

11. Pynına T.Iý. Vnedrenıe transnatsionalnyh 1zdatelskıh korporatsı1 na gazetnyı rynok Vengrı // Vestnık Moskovskogo ýnıversıteta. Serıı 10. «Jýrnalıstıka». 1991. № 3. S. 70-73.

12. CIO-Wechsel bei Bertelsmannhttps://www.cio.de/a/cio-wechselbei-bertelsmann,3593415

13. WAZ Westdeutsche Allgemeine Zeitung ePaper. https://www. ikiosk.de/shop/epaper/waz-westdeutsche-allgemeine-zeitung.html

14. Pavli D. Berlusconi's Chilling Effect on Italian Media // Blog Open Society (http://blog.soros.org/2010/03/ berlusconischillingeffect-on-italian-media

15. Bajomi-Lazdr P. Media es Politika . Budapest: Antenna Konyv, 2010. 
16. Élet és Irodalom https://magyarbrands.hu/interjuk/elet-esirodalom/

17. Kortárs, 1967. II.1348-1349.p.; lásd még Program és hivatás. i. m. 721.p.

18. Jelentős kulturális folyóiratok szűnnek meg. kulter.hu, 2016. április 29. [2016. június 13-i dátummal az eredetibőlarchiválva]. (Hozzáférés: 2017.01 31.)

19. Bajomi-Lazar P. Media es Politika. Budapest: Antenna Konyv, 2010. 233 old.

20.Új magyar irodalmi lexikon III. (P-Zs). Főszerk. Péter László. Budapest: Akadémiai. 1994. 2053. o.

21. Reform 1988-1998 https://adtplus.arcanum.hu/hu/collection/ ReformTokePeter/

22. World Newspapers and Magazines - Hungary». Worldpress. Retrieved 10 May 2008.

23. Nagy Pál: A Hitel folyóirat húsz esztendeje, Székelyföld, 2009/4.

24. Magyar Narancs https://magyarnarancs.hu/

25. Peform. 1989. 11 februar. 26. Magyar hirlap. 1988. 16. 11.

27. Peform. 1989. 15 februar.

28. Népszava. 1988.16.07. 29.Peform 1989. 17. 02.

29.Peform 1989. 17. 02.

30. Népszabadság sold to Mediaworks Hungary Zrt. The Budapest Beacon (24 11ýnı 2015).

31. Mediaworks Hungary suspends publication of Népszabadság and nol.hu - The Budapest Beacon (8 October 2016).

32. Magyar Nemzet http://mrtranslate.ru/smi/hungary/magyarnemzet/

33. Magyar Hírlap https://hu.wikipedia.org/wiki/Magyar Hírlap

34. XXI media https://xximedia.hu/nepszava

35. Magyar hírlap 1989. 04. 01.

36. Magyar hírlap 1989. 08. 01.

37. Népszabadság. 1989.11.01.

38. Népszabadság 1989. 30. 01.

39. Magyar hírlap 1989. 30. 02.

40. Magyar hírlap 1989. 04. 01.

41. Népszava 1989. 05. 04.

42. Magyar hírlap 1989 10. 23. 


\section{7. Медіаправо в Угорщині на сучасному етапі}

У процесі покращення функціонування багатоманітних засобів масової інформації мас-медіа стає нагальною потребою у становленні та розвитку інформаційного суспільства. Засоби масової інформації, з урахуванням їх суспільної ваги, визначені як складова правовідносин з відповідним відображенням у нормативно-правових актах: законах та підзаконних документах органів виконавчої і судової гілок влади. Вищезазначене дає право стверджувати той факт, що суспільні відносини щодо масмедіа $є$ предметом права у розумінні його як напряму наукових досліджень.

Тому тема вивчення медіаправа як окремої галузі юридичної науки $є$ надзвичайно актуальним та важливим завданням для українських учених.

У цьому плані надзвичайно корисним $є$ вивчення досвіду зарубіжних країн. Ми вирішили взяти об'єктом нашого дослідження Угорщину. Чому саме цю країну? Угорщина є постсоціалістичною державою і на своєму шляху до верховенства демократії та права досягла значних успіхів, а ті процеси, які проходять у цій царині, слугують прикладом для інших країн, що вибрали схожий шлях перетворень. Це повністю стосується України, яка прагне стати повноправним членом Свропейської спільноти.

Дослідники медіаправа, розглядаючи окремі фрагменти правовідносин, регулювання діяльності ЗМІ, визначення його структури та місця в системі права, зокрема як системи знань і як системи наукових досліджень, не приділяли належної уваги вивченню зарубіжного досвіду в цій царині, зокрема в Угорщині. 
Із врахуванням зазначеного вище, мету даного розділу сформулюємо таким чином: дослідити головні напрямки створення та функціонування медіаправа в Угорщині; на підставі аналізу визначити деякі особливості, притаманні саме цій країні у цьому складному процесі.

Критична маса інформації, знань, нормативно-правових актів дозволяє висловити позицію про формування в праві такого феномену, що можна умовно визначити як медіаправо, дослідження про юридичне забезпечення діяльності засобів масової інформації (далі - ЗМI). Актуальність проблематики щодо медіаправа має важливе значення як для правотворчості, так і для правозастосування, а також для правової освіти та юридичної науки (зокрема, для розвитку теорії інформаційного права).

Одним із важливих аспектів реалізації мети і завдань становлення та розвитку інформаційного суспільства $є$ різноманітні засоби масової інформації, масмедіа. Вони, по суті, визначають зміст (контент) багатьох напрямів і видів інформаційної діяльності в суспільстві. Враховуючи важливість для нього масмедіа, вони визначені й як складова правовідносин з відповідним відображенням у нормативно-правових актах - законах та підзаконних документах органів виконавчої і судової гілок влади. Зазначене дозволяє констатувати факт, що суспільні відносини щодо масмедіа $€$ предметом права у розумінні його як сфери суспільних відносин та як напряму наукових досліджень.

Після зміни режиму, яка відбулася в Угорщині у 1990 році, у країні діяв Закон про пресу, що був прийнятий у 1986 році. Державні збори країни внесли до нього поправки в січні 1990 року. Однак вони стосувалися лише друкованої преси та не торкалися електронних 3МI.

У подальшому уряд Й. Анталла робив неодноразові спроби внести у Державні збори проєкт Закону про ЗМI, але кожного разу ці зусилля провалювалися через рішучий супротив опозиції [1].

Закон про засоби масової інформації намагався розробити один зі спеціальних комітетів Круглого столу між владою та опозицією, але вони не змогли погодити текст законопроєкту. Пізніше, коли був сформований уряд Угорського демократично- 
го форуму, його керманич Йожеф Анталл заявив, що загальною провиною Круглого столу було те, що йому не вдалося врегулювати питання 3МI [2]. Політичний попит на закон був сформульований у пакті МДФ та СВД, про те, що Закон про ЗМІ потрібно прийняти якнайшвидше[3].

Однак рішенням Ради Міністрів на чолі з Міклошем Неметом у 1989 році був уведений мораторій на будь-які зміни до цього Закону. Цим вони хотіли запобігти використанню радіо та телебачення для політичних цілей, а саме підготовки до виборів. Елемер Ханкісс та Шаба Гомбар здійснили прохання Президента, знаючи, що їхній мандат триватиме до вступу в дію Закону про ЗМІ. Вони обидва були причетні до Закону.

У той ж час, була достатня кількість підприємців, які чекали можливості запустити комерційні канали радіо та телебачення. На той час було подано п'ятдесят заявок на п'ять супутникових та три наземних телевізійних канали, шістдесят - для отримання радіочастот.

Президент Угорщини Арпад Гьонц наприкінці 1991 року заявив, що ситуацію зі 3МІ можна вирішити лише прийняттям Закону про 3МI, через рік він знову висловив надію, що уряд та опозиція знайдуть спільну мову в цьому питанні.

Разом з тим, ситуацію погіршило те, що у цей час відносини між урядом та лідерами державних 3МІ погіршилися.

Парламент голосував за Закон в останні дні грудня 1992 року. В останню хвилину комітет з конституційних питань Д3 вирішив провладною більшістю, що цей Закон можна прийняти простою більшістю. Однак опозиція наполягала на тому, що Закон в цілому потребує більшості в дві третини. Голосування принесло неочікуваний результат. Незважаючи на те, що було прийнято 669 поправок, під час остаточного голосування Закон про 3МІ не отримав жодного голосу. Ні члени уряду, ні провладні депутати його не підтримали. Потім правлячі партії та опозиція звинувачували один одного у тому, що сталося.

Голландський політолог Б. Гійсберс підсумував це так: «Ми мусимо констатувати, що наприкінці року парламентська демократія зазнала поразки. І це не лише поразка уряду та опозиції, а й угорського суспільства» [4 
УСП на парламентських виборах 1994 року отримала 54\% голосів, хоч УДФ отримало значну підтримку ЗМІ, насамперед радіо та телебачення, йому це не допомогло. Виборці зробили свій вибір на користь соціалістів і не взяли до уваги медійну пропаганду. УСП могла би самостійно сформувати уряд, але соціалісти вирішили вступити у коаліцію з СВД. Вони сподівалося, що завдяки цьому союзу Угорщина зміцнить демократичні інститути, створені в 1990 році, зуміє досягти успіху на шляху вступу країни до НАТО та Європейського Союзу, зміцнить ринкову економіку, буде гарантувати демократичне суспільне життя. У медіасвіті коаліція обіцяла мир і Закон про ЗМІ.

Однак, після формування уряду першого конфлікту чекати було не довго. Прем'єр-міністр Дюла Хорн передав на підпис Президентові Республіки пропозиції щодо призначення нових керівників Угорського радіо та Угорського телебачення. Опозиційні партії УДФ, ХДНП, ПНДХ, Фідес звернулися до Арпада Гьонца, попросивши його не підписувати документи про призначення, нагадавши, що саме він був палким прихильником миру в ЗМІ. Однак, Президент Республіки в середині липня призначив Адама Хорвата президентом угорського телебачення, Ференца Шекелі - віцепрезидентом.

Почався процес, який повториться під час наступних змін уряду, нові керманичі, що прийшли до влади, замінили всі керівні кадри провідних 3MI, а на їх місце були призначені нові люди з новим баченням діяльності масмедіа.

Президент Республіки також звільнив з посади Іштвана Стефка - керівника редакції радіо, і призначив на цю посаду Яноша Бетлена, в той же час був звільнений з керівника УТА Балаш Варкон та призначений на його місце журналіст-ліберал Мадяр Ірлап.

Йожеф П. Сабо, головний редактор радіо Кошут, був звільнений, а новим керівником став Габор Рекай. На радіо Петофі Ласло Радноті замінив Еріку Шаркезі.

Конституційний Суд визнав неконституційним положення, згідно з яким бюджет державних засобів масової інформації визначався урядом. У свою чергу, уряд змінив організацію та діяльність угорського телебачення. Ці новації були прийняті 
урядом Анталла після відсторонення у 1993 році від посади президента угорського телебачення Елемера Ханкіша. Вони стосувалися посилення контролю з боку влади за редакційною діяльністю державних телеканалів.

У той же час економічна ситуація на телебаченні була катастрофічною, дефіцит установи на момент зміни президента становив 2,4 мільярди фунтів. Тому було заплановано грунтовну реструктуризацію, яка повинна була призвести до значного скорочення персоналу.

Знову виникла потреба у прийнятті Закону. Президент Угорщини також закликав якнайшвидше прийняти Закон про 3МI. Однак, шанси на його прийняття в 1994 році були невеликі, цього разу через розбіжності в підходах до цього питання між двома коаліційними партіями.

У березні 1995 року уряд вирішив скоротити штат угорського телебачення на тисячу осіб. На телебаченні було утворено страйковий комітет, який звернувся до Конституційного Суду. Крім заяви про незаконність, вони хотіли домогтися того, щоб уряд не вживав таких різких дій до того, як Закон буде прийнятий. Конституційний Суд постановив, що рішення уряду про скорочення штату є неконституційним, оскільки уряд не має повноважень контролювати телебачення.

Ще до того, як уряд Анталла прийшов до влади, приватизація друкованої преси розпочалася і значною мірою завершилася. Нова влада сприйняла це як велику втрату та неможливість отримати «власну пресу». Тому свою увагу вони зосередили на угорському радіо, яке може охопити більшу аудиторію.

Вони також звернули особливу увагу на телебачення, але їм не вдалося розробити сучасну модель державного урядування в медіасфері, подібну європейській практиці. Жодна медіастратегія не була розроблена та впроваджена у життя. Не вдалася прийняти Закон про ЗМІ. Початковий період побудови демократичного суспільства в Угорщині характеризувався такими моментами:

- гострим протистоянням консервативної та ліберальної ідеологій у боротьбі за медіа. Ідеологічне протистояння супроводжувалося докорінними розбіжностями, політична відстань між правими і лівими силами збільшилася, проміжок поглибився; 
- боротьба політичних сил, у свою чергу, спровокувала протистояння і відповідний поділ серед журналістів;

- цей процес супроводжувався вуличними демонстраціями неурядових організацій. 3 одного боку, вони вимагали відсторонити від займаних посад президентів радіо і телебачення, тоді як ліві демонстранти виступали проти правої загрози;

- також серед політиків, медіа-аналітиків та журналістів усе частіше лунала думка про те, що краще було прийняти поганий Закон про 3MI, ніж допустити беззаконну війну;

- уряд Анталла узурпував право роботодавця на призначення директорів радіо і телебачення, відповідно використавши указ 1974 року. Намагався призначених нових керівників та чинних президентів звільнити з роботи. Президент Республіки не піддавався цьому тиску. Однією з визначальних фаз війни в ЗМІ того часу була ця серія конфліктів;

- боротьба за ЗМІ стала надбанням громадського дискурсу. Ця тему по-різному висвітлювалася у 3МІ, у залежності від політичних уподобань кореспондентів;

- у 1994 році була розвіяна ілюзія про те, що урядова партія, яка домінує у ЗМІ, може стати переможцем у наступних виборах. У свідомості політиків знову і знову цей сценарій формується, але виборці вирішили змінити уряд також у 1998 та 2002 роках. Доведено, що вплив 3МІ на електорат не означає автоматичної перемоги на виборах. Хоч на поведінку виборців впливає інформація, отримана зі ЗМІ, крім того, на них впливають інші фактори, наприклад, власний досвід, життєвій рівень, довіра до тих чи тих політиків.

У 1996 році таки був прийнятий Закон про засоби масової інформації, що набув чинності 1 лютого цього року [5]. Підготовку Закону здійснювали Міністерство юстиції і Міністерство культури та народної освіти, його обговорювали Погоджувальна рада коаліції, опозиційні й урядові партії, комітет з культури Державних зборів, державні секретарі відповідних міністерств та відомств на своїх засіданнях, а потім і уряд. 21 грудня 1995 року парламент прийняв Закон про ЗМІ з підтримкою на 90\%, не голосувала тільки фракції партії дрібних власників. 1996/1 Закон набрав чинності 1 січня 1996 року[6]. 
У Законі про 3МІ Державні збори визначили основні принципи та правила мовлення. У межах цього було встановлено процедурні правила отримання прав на мовлення й визначено організаційні засади суспільних мовників. Одним з найважливіших положень Закону є створення Національної ради з питань телебачення і радіо (НРТР) та їі Комітету зі скарг.

Закон про ЗМІ також застосовується як державними установами, так і приватними компаніями. У ньому надається чітке роз'яснення щодо певних дефініцій:

- мовлення означає регулярне транслювання радіопрограми або телевізійної програми з фіксованим позначенням за попередньо оголошеним часом програми на визначеному та загальнодоступному каналі будь-якої системи теле- чи радіомовлення для кожного, хто має можливість його приймати;

- розповсюдження програми: одночасне передавання сигналів, що виробляються мовником, дротовою (кабельною) мережею, а також наземною або супутниковою радіотелекомунікаційною системою мовлення, до їх радіо- і телевізійних радіостанцій та мереж мовлення;

- мовлення означає однонаправлену радіотелекомунікаційну процедуру з наземною або супутниковою системою, призначену для теоретично необмеженої кількості користувачів 3 відповідним приймачем для передавання звуку, зображень або інших сигналів;

- мовлення: одночасне, незмінне передавання широкомовного сигналу, що виробляється мовником, до приймача користувача електронними засобами.

Відповідно до регламенту $\mathrm{CC}$, телевізори повинні мати захисний чіп, який фільтрує програми, які сповістять про те, що вони не рекомендуються для неповнолітніх. У цьому випадку телевізор вимикається.

Було визначено п’ять категорій телевізійних програм:

1. можна переглядати незалежно від віку;

2. може викликати страх у глядача віком до 12 років або щось, чого вони не можуть зрозуміти з раннього віку або неправильно зрозуміти. Рейтинг такої програми: дітям віком до дванадцяти років рекомендується дивитися ії̈ під наглядом дорослих; 
3. може згубно впливати на фізичний, розумовий чи моральний розвиток осіб віком до 16 років, ідентифікується опосередкованим посиланням на насильство чи сексуальність або тим, що конфлікт вирішується насильницьким способом. Рейтинг такої програми: не рекомендується дітям віком до шістнадцяти років. Вона може транслюватися між 21.00 та 05.00 і належним чином позначена;

4. здатна негативно впливати на фізичний, розумовий чи моральний розвиток неповнолітніх, зокрема, визначаючи насильство або пропаганду сексу. Рейтинг такої програми: не рекомендується дітям віком до вісімнадцяти років. Програма може транслюватися лише між 22.00 та 05.00, з відповідним позначенням;

5. може мати серйозний негативний вплив на фізичний, психічний або моральний розвиток неповнолітніх, зокрема через порнографію або крайнє, або невиправдане насильство. Програма не має права на трансляцію.

3 прийняттям Закону можна говорити про трансформацію інституційної системи у функціонуванні радіо і телебачення в Угорщині. Найважливішим елементом Закону $є$ те, що базова структура діяльності цих ЗМІ, яка була введена в більшості європейських країн, упроваджена і в Угорщині: нею було започатковано, поряд із державними, комерційні радіо та телебачення. Таким чином, з позиції професійних, юридичних і фінансових принципів програми суспільного мовлення, як постачальник загальнодоступних послуг, можуть бути у приватній власності. У той же час засоби масової інформації, що знаходяться в державній власності - Угорське радіо і телебачення, Дунайське телебачення - не могли мати комерційні канали.

У Законі про ЗМІ говориться, що одним з основних принципів $є$ те, що мовлення в Угорській Республіці є безкоштовним. Мовник самостійно визначає зміст мовлення й несе за нього відповідальність. Однак мовник повинен поважати конституційний порядок, його діяльність не повинна порушувати права людини, і він не мусить розпалювати ненависть стосовно людей, народів, націй, національних, етнічних, мовних та інших меншин або проти будь-якої церкви чи релігійної групи. Мов- 
лення не може бути направлене на явне або приховане порушення прав будь-якої меншини чи більшості, що грунтується на расистській ідеології.

У Законі сформульовано в якості одного з найважливіших принципів інформування те, що інформація про внутрішні та зарубіжні події і спірні питання, які становлять суспільний інтерес, повинна бути універсальною, фактичною, своєчасною, об'єктивною та збалансованою. Усі матеріали, які готуються до ефіру, за змістом і жанром не повинні віддзеркалювати погляди певної партії або політичного руху.

Серед принципів мовлення Закон визначає відсоток програм, що вироблені в Угорщині, правила реклами й підтримки програм (спонсорство) суспільного мовлення.

Контроль над засобами масової інформації покладається на Національну раду з радіо і телебачення (НРРТ). Цей орган складається з представників, делегованих усіма партіями на паритетній основі й обраних парламентом у 1996 році на чотири роки. Після закінчення терміну їх повноважень, Прем'єр-міністр та Президент спільно призначають 7 членів НРРТ. Для забезпечення поточної роботи при Раді створюється секретаріат.

Головним завданням НРРТ є захист і заохочення свободи вираження думок, полегшення виходу мовників на ринок, руйнування інформаційних монополій, у тому числі, запобігаючи створенню нових, а також охороняючи незалежність мовників. Вона контролює реалізацію конституційних принципів свободи преси та інформує про це Державні збори.

Положення про діяльність НРРТ передбачає можливість звернення до цього органу з відповідними скаргами. Насамперед це стосується порушення вимог до інформаційного контенту. Наприклад, якщо мовник подає викривлену, односторонню позицію щодо соціально важливої проблеми, яка кривдить певну частину населення, Рада може вивчити скаргу й, у вагомих випадках, накласти штраф. Закон також передає Мовний фонд та Фонд підтримки телерадіомовлення під управління НРРТ, яке вона визначає в якості одного з основних інститутів фінансування ЗМІ. Фінансування надається за комунальною і комерційною моделями. Громадське радіо й телебачення мають пра- 
во на певний відсоток від абонентської плати, також відомої як технічне обслуговування обладнання. Крім того, суспільні ЗМІ можуть розміщувати рекламу, але з певними обмеженнями та приймати спонсорську допомогу.

Державний бюджет зобов'язаний оплатити витрати, пов'язані з організацією мовлення. На додаток до останнього, державні засоби масової інформації можуть просити уряд і парламент надати їм державну підтримку для реалізації цілей, визначених Законом, хоч виділення цих коштів має певні обмеження.

Засоби масової інформації також можуть укладати угоди про підтримку 3 певними державними органами та міністерствами для виконання конкретних завдань програм опікунських рад. Ці ради складаються з десяти членів - представників парламентських партій (п’ятдесят відсотків репрезентують уряд, а п’ятдесят - опозицію) і працюють протягом чотирьох років. Інші 23 члени рад делегуються Громадським фондом Угорського телебачення (Hungária Televízió), національними та транскордонними професійними і громадськими організаціями, визначеними Законом. Термін їх повноважень становить усього один рік.

Закон містить докладні правила придбання прав на мовлення та відповідні умови проведення торгів. У цьому документі існує окрема глава про проведення тендерів на використання національної радіочастоти Дунайського радіо, а також другим каналом УТБ. У Законі також передбачається, що програми другого каналу УТБ повинні транслюватися із супутника, а Угорське радіо отримає дві сучасні частоти CCIR від держави. 3 часу прийняття Закон піддався нещадній критиці з боку журналістської спільноти. Насамперед засудження стосувалося того, чого від цього документа найбільше очікували - гарантування того, що чинна влада не буде зловживати державними радіо та телебаченням на свою користь, і це очікування не виправдалося.

Згідно з опитуванням, проведеним угорським соціологом Марією Вашахей: «У 1997 році більше двох третин журналістів повністю або частково погодилися з твердженням, що Закон про ЗМІ не скасовує залежність електронних ЗМІ від політич- 
них партій, які були при владі, вони чинили політичний тиск, здійснювали інституціолізований контроль над радіо та телебаченням» [7].

Інші аналітики характеризували Закон про ЗМІ як інституціоналізацію політичного втручання через опікунські ради та НРРТ у сфері електронних ЗМІ. А саме парламентські органи та його фракції висували членів НРРТ.

Позитивним у Законі є те, що він скасував частотний мораторій, зробивши можливим наземне комерційне телебачення в Угорщині. Заснував подвійну медіасистему, в якій поряд 3 комерційними каналами відігравали певну роль громадянські й соціальні медіа. Президенти радіо та телебачення більше не призначалися на підставі представлення прем'єр-міністра та указу Президента, а на основі рішення опікунської ради, яка потім отримала назву Громадська велика опікунська рада, саме вона обрала більшістю у дві третини голосів керівників цих установ.

3 набранням чинності Закону абонентську плату за телебачення було скасовано, але залишилася плата за технічне обслуговування, розмір якої визначено в Законі про бюджет. Відтоді Мадяр Телевізіо міг залишити собі лише 50\% прибутку, 28\% - Мадяр Радіо, 14\% - Дунайське телебачення, 2\% - НРРТ та громадські фонди 3МI, 6\% - інші 3МI [8].

Державні зори обирали президента та членів НРРТ. У 1996 році за поданням прем'єр-міністра Дюли Хорна Президент призначив Міхала Ревеса першим президентом Ради. Новинкою Закону про ЗМІ стала процедура подання заявок на президентство. У той час ніхто не подумав, скільки труднощів спричинить ця новація на практиці. На цю посаду претендували десятки осіб, але жоден із них не відповідав професійним вимогам.

Тим не менше, обрали головами опікунських рад на телеканалі «Дунай» Шара Шандора, а на Угорському радіо - Іштвана Гайду.

На початку осені 1996 року державні медіа-установи були перетворені в акціонерні товариства, при цьому вони успадкували їх платіжні зобов'язання у розмірі близько 9 млрд форинтів.

Прийнятий у 1996 році Закон проіснував 14 років. За цей час в Угорщині змінилося кілька урядів: соціалісти на чолі 3 
Дьюлою Хорном; перший кабінет Віктора Орбана; потім два цикли правління соціалістів, які очолювалися Петером Медеші, Ференцом Дюрчані та Гордоном Байнаї. Закон про ЗМІ був так розроблений, що витримав усі спроби його змінити. Найголовніші питання, закладені в ньому, не можна було змінити простою більшістю. Було потрібне досягнення компромісу, передусім з опозицією. Критиці насамперед піддавалося положення про незалежність ЗМІ від політичних партій. Насправді правлячі партії користувалися своєю владою для того, щоб використовувати незалежні медіа в своїх цілях.

Закон про ЗМІ потребував модернізації, проте істотних змін практично не було зроблено. У результаті ліві ЗМІ мали суттєву перевагу в країні, що викликало справедливу критику та неприйняття правими силами. Останні зробили значні зусилля, щоб повернути вплив на ЗМІ. Тому в листопаді 2009 року був знайдений компроміс, коли НРРТ потрапив під вплив ФІДЕС. Радіочастота Данубіус, хоч формально була під контролем соціалістів, матеріально стала залежна від ФІДЕС.

У результаті впровадження Закону в Угорщині склалася подвійна система 3МІ. 3 одного боку, в деяких медіа-установах політичні інтереси брали гору над професійними аспектами та правдивим відображенням тих чи тих подій. 3 іншого - 3МІ, що займалися суспільним життям і політичними подіями, стали заідеологізованими. У руках партій були зосереджені газети, радіо, телебачення. Масмедіа стали ареною виступів політиків, значно зросла їх роль у боротьбі за владу.

Виявилося, що Закон про ЗМІ не призвів до більш вільної, незалежної преси, оскільки вона стала полем для політичних ігор. Уряди змінювалися, але масмедіа, які Законом гарантувалася як незалежні, ставали частиною політичної здобичі чергового керівництва країни.

Державні засоби масової інформації зменшували свою вагу, у той же час, комерційне телебачення та радіо підкорювали все більше глядачів і слухачів. Ці програми значно трансформували ринок телебачення та радіо. Посилилася боротьба за глядача й слухача, в якій важливу роль відігравали також підприємці, пов'язані з партіями та партійними угрупуваннями. 
Між 1996 та 2010 роками у сфері комунікації з'явилися нові методи й засоби, які набули поширення за короткий час. Докорінно трансформував медіаринок і змінив звички споживання медіа-аудиторії. До кінця 2010 року Інтернет перейняв першість у телебачення. Комп'ютер, його екран також дозволив користувачеві вирішити: він хоче читати «газету» на моніторі, слухати радіо чи дивитися телевізор. Пізніше монітор узяв на себе і роль смартфона.

Окрім традиційного (одностороннього) масового спілкування, розвинулося і горизонтальне спілкування. Сьогодні споживачі знають про все часто одночасно з подіями, вони можуть бути навіть більше поінформовані про події, чим це надають їм 3MI.

Медіаконтент значно збільшився, оскільки Інтернет завоював увесь світ, він став набагато демократичнішим, ніж будьколи раніше, потреба споживача інформації на початку XXI сторіччя визначається майже винятково якістю його інтересу.

Хоча уряд УСП - СВД, який прийшов до влади у 1994 році, у Державних зборах мав більшість у дві третіх голосів, тим не менше, їм для прийняття Закону про ЗМІ знадобилося ще півтора року. Закон про засоби масової інформації 1996 р. підтримала не тільки парламентська коаліція, а і партії, які знаходилися в опозиції.

Хоч різниця у підходах до Закону між політичними сторонами була суттєва на час його прийняття, все ж компроміс між владою та опозицією був досягнутий, зміни були внесені під час переговорів про вступ до СС відповідно до європейських вимог щодо гармонізації законодавства.

Більш того, у 2008 році між УСП та Фідес було заключено політичну угоду щодо національних комерційних радіостанцій, але вона була скасована Конституційним Судом.

Позитивним результатом у медіасфері $є$ те, що в Угорщині склалася дуальна система ЗМІ внаслідок набуття чинності Закону про ЗМI.

В установах, які керували ЗМІ, професійні міркування часто замінювалися політичними інтересами, саме так приймалися рішення щодо стратегії медіа. 
Уряди по-різному діяли щодо цього, наприклад, у 1998 р. уряд проголосив необхідність позитивної дискримінації зі свого боку щодо ЗМІ. Для цього один із мільярдерів створив щотижневу газету з бюджетною підтримкою.

ЗМІ стали ареною виступів політиків, важливість засобів масової інформації зросла. У середовищі партій та партійних лідерів в Угорщині з'явилися спікери.

Політичні дебати були поширеними на початку епохи, і 3 часом вони були замінені політичними монологами. Навіть традиційні дебати між кандидатами в прем'єр-міністри у 2010 році не відбулися.

ЗМІ, що традиційно висвітлювали тільки громадське життя та політичні події, стали повідомляти і про партійне життя, набули ідеологічного забарвлення. Як правило, газети, радіо та телебачення зосереджені в руках підприємців, прив'язаних до владних структур.

ЗМІ різної спрямованості по-різному повідомляють про події дійсності. У новинах глядач бачить у різних мовників відмінний підхід до тієї ж самої події.

Зазвичай читачі та глядачі залежно від їхньої політичної орієнтації прагнуть отримати від ЗМІ підтвердження своїх переконань і правильності власних оцінок та думок.

Закон про ЗМІ не призвів до більш вільної, незалежної преси, адже ця сфера також стала полем для політичних ігор. Уряди змінювалися, але незалежно від їх ідеологічних уподобань вони вважали ЗМІ частиною своєї політичної здобичі й відповідним чином з ними поводилися.

Більшість керівників масмедіа здебільшого приймають рішення на основі політичних міркувань, як правило, на догоду владі.

Зменшилася важливість засобів масової інформації, що належать до державних та громадських служб, національні комерційні телебачення охопили більшість глядачів. Комерційні канали стали більш конкурентоспроможними порівняно з суспільним телебаченням. Ці програми значно трансформували ринок телебачення.

Посилилася боротьба за право виробляти програми. У цій 
боротьбі важливу роль відігравали також підприємці й підприємства, пов'язані з партіями. Рішення, контракти були здебільшого непрозорими, у телебаченні процвітає корупція.

Між 1996 та 2010 роками за короткий час з'явилися і поширилися нові методи та засоби в галузі комунікації.

Окрім традиційної (односторонньої) масової комунікації, розвинулася горизонтальна комунікація. Сьогодні споживачі можуть бути поінформовані про все часто одночасно з подіями, і навіть можуть бути кореспондентами самих подій.

Серійні газети були замінені значною кількістю таблоїдних паперів. Кількість примірників серіалів докорінно скоротилася. Безкоштовні газети, розповсюджені в сотнях тисяч примірників, з'явилися на ринку. Зменшення кількості копій сторінок газет також пов'язане з тим, що кожен друкований орган створив свою безкоштовну онлайн-версію.

Підсумковий висновок епохи про те, що медіаконтент значно збільшився, став набагато демократичнішим, оскільки Інтернет став усюдисущим, ніж будь-коли раніше.

Після чергових парламентських виборів новим прем'єром з 29 травня 2010 року став Віктор Орбан, лідер правої коаліції ФІДЕС - Християнсько-демократична народна партія, що отримала конституційну більшість. Це створило можливість для перезавантаження законодавчої бази діяльності ЗМІ.

18 квітня 2011 року Державні збори Угорщини прийняли нову Конституцію - Основний Закон країни, яка набрала чинності 1 січня 2012 року. В цьому документі спеціальним параграфом 61 було визначено основоположні принципи діяльності ЗМІ. Так, у першому пункті зазначено, що в Угорській Республіці у кожного існує право на вільне вираження міркувань, а також на те, щоб знати відомості, які представляють суспільний інтерес i, відповідно, право розповсюдження їх.

У другому пункті констатується, що Угорська Республіка визнає і захищає свободу друку.

Третім пунктом визначено таке: «Для прийняття закону про публікації відомостей, які являють суспільний інтерес, а також свободи друку, необхідно голосування двох третин присутніх депутатів Державних зборів». 
Четвертим пунктом було визначено: «Для прийняття закону спостерігання за діяльністю державного радіомовлення, телебачення і інформаційного агентства, а також призначення їх керівників, рівно як і дозволу комерційного радіо і телебачення, також запобігання інформаційних монополій необхідно голосування двох третин присутніх депутатів Державних зборів» [9].

Таким чином, скориставшись тим, що у Державних зборах урядова коаліція мала кваліфікаційну більшість, були створені умови для прийняття нового законодавства діяльності ЗМІ в Угорщині. 22 липня 2010 року Державні збори прийняли Закон, що регулює засоби масової інформації та комунікації [10], згідно з яким Національне радіо й телебачення і Національний орган зв'язку були перетворені у Національне відомство засобів масової інформації та комунікацій (НВЗМІК). НВЗМІК є автономним органом державного управління, який бере участь у керуванні сферою комунікацій і здійсненні державної політики у цій царині. Цей орган обирається Державними зборами, він $є$ автономним, з незалежною правосуб'єктністю. Ця організація руйнує інформаційні монополії, захищає незалежність мовників та гарантує свободу вираження поглядів, контролює самостійність преси на основі конституційних принципів і повідомляє про цю діяльність Державні збори.

Президент та чотири члени НВЗМІК обираються двома третинами більшості Національних зборів за поданням Прем'єрміністра строком на дев'ять років. Закон надає можливість Угорському суспільному фонду радіо, Угорському суспільному фонду телебачення та Суспільному фонду телебачення «Унгарія» створити Державний суспільний фонд, який $є$ «державним мовником та службою новин і захищає свою незалежність».

Як орган управління, він створив Опікунську раду, що є керівним органом суспільного фонду та обирається двома третинами депутатів Національних зборів. Половина членів ради - провладна, інша половина пропонується опозицією. Строк повноважень членів Опікунської ради становить дев'ять років.

11 червня 2010 року депутати Державних зборів Андраш Чер-Палковіч та Антал Роган подали до парламенту проєкт За- 
кону про свободу преси та захист медіаконтенту, який отримав назву медіаконституція. Закон був прийнятий парламентом 2 листопада 2010 року та замінив Закон про пресу, який діяв 3 1986 року [11].

Він визначив, що означає медіаслужба, як здійснюється відстеження та пошук медіасервісів, як діє лінійний аудіальний медіасервіс, що таке медіаконтент та контент-провайдер. Це законодавство поширилося на весь медіаконтент, у тому числі й на Інтернет.

Положення передбачали, що кожен має право висловлювати свої погляди через засоби масової інформації. Для офіційної реєстрації органу масової інформації необхідно взяти участь у тендері.

Закон також включав право громадянина отримати відповідь на його запит від будь-яких медіаресурсів, у тому числі й від Інтернет-провайдерів. Закон визначив у окремій главі зобов'язання преси. Вони полягають у тому, що ії обов'язком $є$ надання достовірної, швидкої, точної інформації для споживачів з питань національного та європейського суспільного життя, а також про події, важливі для угорців.

Ці два Закони, про які йшла мова вище, викликали різку критику в Свропейському Союзі, всі великі європейські періодичні видання вкрай суворо висловилися про них, вживаючи серед інших і такі визначення, як «шовіністичний». 3 моменту прийняття Закону своє занепокоєння висловили всі найбільші міжнародні інститути - ООН, Рада Європи, ОБСЄ. Ці нові Закони, які набули чинності 1 січня 2011 року, призвели до повного контролю ЗМІ Угорщини з боку уряду, а це, у свою чергу, підриває демократичні цінності та авторитет Свросоюзу [12].

Найбільший медіадослідник Угорщини Петер БайоміЛазар вважас, що влада сьогодні може безпосередньо впливати на контент 3МІ. Крім того, його занепокосння викликас і неточність низки визначень Закону, що дозволяс порізному його трактувати [13].

Наглядовий та керуючий урядовий орган, який опікується 3MI, також отримав право стягувати колосальні штрафи (дохо- 
дять до \$ 900000 для радіо і телебачення) із засобів масової інформації за «незбалансоване висвітлення подій».

Тож не дивно, що документ викликав хвилю обурення в угорській пресі. Ще в грудні 2010 року дві щотижневі угорські газети - Magyar Naracs i ES - вийшли з незаповненими передовицями, протестуючи проти нового Закону про ЗМІ. Пізніше колег підтримали дві найбільші газети Угорщини - Nepszabadsag i Nepszava[14].

Зокрема, газета Nepszabadsag, лідер ринку Угорщини за тиражем, опублікувала на передовиці рядок «Свободі преси в країні прийшов кінець», продублював їі на мовах усіх 27 країн ЄC. У редакційній статті газета пояснила, що новий Закон знадобився уряду країни, щоб «дресирувати, карати і мучити тих, у кого є своя думка». Крім того, газета пообіцяла звернутися в Конституційний Суд Угорщини. Підтримали угорських колег i редакції видань інших країн СС [15].

Свропейські чиновники і правозахисники також виступили проти прийняття Угорщиною нового Закону про ЗМІ. Представник ОБСЄ $з$ питань ЗМІ зазначила, що сама наявність подібного Закону призведе до самоцензури в редакціях угорських видань, що неминуче відіб'ється на свободу ЗМІ в країні. Утім, представники уряду, очолюваного Віктором Орбаном, стверджували, що нова норма дозволить забезпечити дотримання законодавчих вимог у превентивному порядку. Крім того, штрафи представники ФІДЕС обіцяли зробити пропорційними до допущеної ЗМІ помилки.

У підсумку угорська газета Nepszabadsag пообіцяла звернутися в Конституційний Суд Угорщини, однак не виключено, що це навряд чи допоможе угорським 3МI. 3 квітня 2010 року Орбан робить усе, щоб закріпити владу ФІДЕС в Угорщині.

Узяття ЗМІ під ковпак - наступний і логічний хід «партії влади». У грудні державні канали країни вже об'єднали в одну систему, віддавши всі головні пости в єдиній компанії прихильникам ФІДЕС. Більш того, новини для цієї компанії будуть проводитися державним інформагентством.

Політичної сили, здатної протистояти цій тенденції, в Угорщині на даний момент немає, але навіть гостра критика з боку 
Єврокомісії не допомогла. Юридичні норми СС передбачають можливість приборкання «паршивої вівці». Питання про прийняття Угорщиною Закону про ЗМІ може бути винесено на розгляд Свропейського суду або країні можуть відмовити в праві голосу в складі парламентських органів СС. Утім, для початку Єврокомісія повинна провести розслідування на предмет розбіжності нового угорського Закону з нормами СС. Зробити це буде непросто, адже у відповідь Угорщина має намір зажадати від Сврокомісії аналізу всіх 27 законів про 3МI, що діють у країнах ЄС. Адже, за словами Орбана, всі норми угорського закону запозичені з законодавства інших країн $С С$ [16].

Але навіть просто проаналізувати угорський документ може бути важко для європейських чиновників. Для того щоб зробити це, як повідомляв Bloomberg, європейцям доведеться вивчити угорську. Справа в тому, що уряд Угорщини «втратив» цілу низку параграфів нового Закону з офіційного перекладу для Євросоюзу. Зокрема, до перекладу не потрапив пункт, згідно 3 яким штрафувати ЗМІ угорські чиновники почнуть лише після 1 липня, якраз коли закінчиться головування Угорщини в СС.

Тим часом, влада Німеччини та Франції вже попросили Угорщину переглянути спірний законопроєкт. У відповідь Орбан заявив, що вважає втручання Парижа і Берліна «недоречним і необдуманим». На його думку, оцінити, чи хороший угорський Закон про ЗМI, може лише Єврокомісія, рішенням якої він пообіцяв підкоритися. Майже одночасно анонімні джерела в дипломатичному корпусі Угорщини повідомили АР, що критику нового Закону про ЗМІ в Угорщині, можливо, оплачують іноземні компанії, незадоволені підвищенням податків у країні [17].

Реакція Орбана на європейські дебати навколо нового Закону взагалі була гострою. Спершу політик вимагав від опонентів залишити при собі їх «західну» думку, а 7 січня через газету The Financial Times запевнив СC, що законодавство Угорщини засноване винятково на європейських цінностях. «У 1998-2002 роках західна преса порівнювала мене з Гітлером. Тепер вони пишуть, що я схожий на Путіна чи білоруського президента», - згадує Орбан, якого уподібнювали російському прем'єру Тhe Washington Post i The Economist. На його думку, подібні порів- 
няння «ображають Угорщину, оскільки це демократична країна» [18].

Угорське регулювання ЗМІ також дало серйозні уроки для ЄC. Європейська комісія та Рада Європи також повинні були визнати, що за відсутності єдиних правил 3МІ в СС, кожна країна - член Спільноти має суверенне право прийняти Закон про 3МI. Відразу після прийняття угорського закону Союз зрозумів, яку серйозну проблему може викликати для демократії у Європі така практика. Наслідуючи приклад Угорщини, комісар ЄС 3 цифрової політики Нелі Крус попросила робочу групу розробити рекомендації до Свропейської комісії щодо сприяння свободі преси та плюралізму в Європі. Групу очолила колишній Президент Латвії Вайра Віке-Фрейберга. Група була створена в жовтні 2011 року з метою перегляду Законів про 3МІ країн-членів та країн-кандидатів і визначення загальних проблем та можливих шляхів їх вирішення. Доповідь Фрейберга, названа на честь голови комітету зі свободи преси $\mathrm{CC}$, була підготовлена у січні 2013 року. Документ не назвав жодних держав-членів, але на основі досвіду він склав тридцять рекомендацій.

Він зазначив, що гарантування вільного функціонування засобів масової інформації залишається насамперед у руках органів держав-членів, але підтримка європейської демократії робить необхідним створення правил СС у цій царині. У ході аналізу експерти розглядали свободу преси у кількох країнах як загрозу демократії і вважали, що різноманітність ЗМІ також обмежена, що спричиняє проблеми для політичних впливів, непропорційний тиск на рекламодавців, постійно мінливі бізнесмоделі та зростання «нових медіа».

За їх досвідом, корінь проблем із свободою слова у ЗМІ, як правило, випливає із законодавства, але є й інші причини, такі як спотворена економіка або відсутність якісної журналістики та безвідповідальна журналістська поведінка. Рекомендації робочої групи включають створення незалежної системи моніторингу засобів масової інформації в СС.

Директива СС могла б передбачити, що кожна держава-член ЄС повинна створити незалежну медіараду, членами якої були 
б представники різних політичних, культурних та соціальних верств населення. Процес призначення у цю медіараду повинен бути прозорим, із забезпеченням відповідних гальм і противаг. Саме започаткування такого органу створило б можливості для заборони такої практики, коли медіа зазнають будь-якого урядового впливу, та впровадити такі суворі правила, які повинні забезпечити внутрішній плюралізм, і саме ця медіарада повинна контролювати дотримання цих правил. У доповіді Фрейберга очікується більша відповідальність не тільки від урядів і органів влади, але і від засобів масової інформації та журналістських організацій.

У запропонованій новій директиві СС говориться, що мовні 3МІ повинні прийняти кодекс етики та кодекси поведінки, і що лише засоби масової інформації з таким кодексом можуть підтримуватися державними коштами [19]. Вайра Віке-Фрейберга вказала, що сьогодні набагато складніше сказати, хто насправді $\epsilon$ журналістом. Тоді як раніше у 3МІ могли працювати лише кваліфіковані журналісти, то зараз в епоху соціальних мереж і блогів, « я думаю, що навчений шимпанзе вже міг би висловити свою думку в Інтернеті». Нелі Крус вважала, що звіт може призвести до дискусії щодо можливих напрямків розвитку масмедіа як на європейському, так і на рівні держав-членів. Вона також говорила про ситуацію в Угорщині: «Ми залишаємося стурбовані угорським законодавством про ЗМІ і вважаємо, що його положення все ще не відповідають європейському законодавству, і угорський уряд не хоче їх виправити» [20].

Слідом за Єврокомісією свою стурбованість з приводу прийняття Угорщиною нового закону про ЗМІ висловила Організація з безпеки і співробітництва в Європі (ОБСЕ). Спецпредставник ОБСС з питань свободи ЗМІ Дунья Міятович назвала деякі аспекти цього закону «проблематичними».

Регулювання аж ніяк не обов'язково означає цензуру, проте грань між ними дуже тонка і «може бути легко порушена, якщо закон сформульований розпливчасто», пояснила Міятович. Ра-ніше спецпредставник ОБСС зустрілася в Будапешті 3 пред-ставниками угорського уряду, щоб висловити їм свої сумніви. Як повідомив статс-секретар уряду Угорщини зі зв'язків з гро- 
мадськістю Золтан Ковач, сторонам не вдалося досягти згоди, однак обмін думками було вирішено продовжити [21].

Уперше після зміни режиму, в результаті парламентських виборів 2010 року, коаліція на чолі з Фідес - ВГС отримала більшість у дві третини Державних зборів. Це дало їм широкі права і можливості, а саме змінити інституційну систему, структуру управління та Конституцію.

Більшість законопроєктів були внесені до Державних зборів окремими депутатами - членами коаліції, що дозволило обійти процедуру консультації з опозицією. Тому час між поданням та прийняттям законів було значно скорочено. За допомогою цього методу через декілька місяців після парламентських виборів система 3MI, орган управління та державна служба були докорінно перероблені.

Прийняттю законів, що стосуються засобів масової інформації та Основного Закону, не передували соціальні, професійні чи змістовні політичні консультації. Для цих двох документів спільним є то, що вони були гостро розкритиковані як усередині країни, так і за кордоном у таких авторитетних міжнародних організаціях, як ООН, РС, ОБСЄ, СС.

Швидко прийнятий Основний Закон та Закон про ЗМІ були змінені декілька разів. Конституція - п'ять разів, а Закон про 3МI - чотири рази. Поправки були внесені урядом, Державними зборами після рішення Конституційного Суду або критики в Свропейському Союзі.

Критика, що супроводжує Закон про ЗМІ та Конституцію, ставить під сумнів прихильність країни до демократії уряду. Уряд відкинув майже всю критику. Він звинувачував критиків у експорті проблем, іноді в державній зраді. Уряд заявив, що веде постійну війну за незалежність, війну та революцію зі своїми внутрішніми й міжнародними супротивникамиНезалежні установи ЗМІ Угорщини очолювали дев'ять осіб, іноді протягом дванадцяти років, які були політично відданими та мали мандат депутата Державних зборів. Критерій професійної компетентності був замінений лояльністю партії.

Цей відбір переважав у виборах Президента та членів органів 3МI. Державні збори призначали лише тих кандидатів, яких 
висував на посади Фідес - ГСП (виключаючи навіть союзника партії). Саме це найгостріше критикувалося як у країні, так і за кордоном.

При призначенні на посаду державного службовця головним критерієм була ідеологічна відданість партії. Жоден уряд не працював так багато з моменту зміни режиму над контролем за діяльністю державних засобів масової інформації. Ця практика нагадує часи режиму Кадара. У практиці ручного керування знову з'являються табу та щоденна практика самоцензури.

Поточна ситуація викликає питання про те, як слід у демократичному суспільстві регулювати засоби масової інформації. На це питання потрібно відповісти як на національному, так і на міжнародному рівнях. Свропейський Союз повинен чітко визначити, що може бути визначено як принцип СС у цій галузі.

В Угорщині слід вирішити, чи законодавче регулювання засобів масової інформації потребує більшості в дві третини голосів депутатів Державних зборів або те, що запропонувала Рада Свропи, має бути пов'язане зі зміною регламенту прийняття найважливіших законів у житті суспільства з обов'язковим позитивним голосуванням депутатів опозиції. Це стосується як Конституції, так і Закону про ЗМI.

Не випадково Прем'єр-міністр Угорщини Віктор Орбан приділив таку увагу контролю за засобами інформації, оскільки вони і надалі визначають політичне життя країни й завжди чітко виявляють свою позицію стосовно правлячого режиму. Політичні сили, які приходили до влади в країні, завжди намагалися використовувати в своїх інтересах цей вплив друку і публіцистики зокрема. В Угорщині періодика в досить великій мірі визначає свідомість інтелігенції та й значної частини населення.

\section{Література}

1. TenyekKonyve-tenyek-konyve-1/1997-11FD1/magyar-allamtarsadalom-politika-14A60/a-mediatorveny-1507A/

2. A Nemzeti Kerekasztal-megállapodás 15. évfordulója: Született szeptember 18-án https://magyarnarancs.hu/belpol/a_nemzeti kerekasztal-megallapodas_15_evforduloja_szuletett_szeptember_18an-53850 . 
3. Pártközi megállapodás, 1990.04.29, 428-429.p.

4. Kéri László: Hatalmi kísérletek, Helikon Kiadó, 2000. C. 250.

5. Közlönyállapot (1996.I.15.) Magyar joganyagok - 1996. évi I. törvény - a rádiózásról és televíziózásról 1996. évi I. tv.)

6. 1996. évi I. Törvény https://hu.wikipedia.org/wiki/1996. évi I. törvény

7. Vasarhelyi Maria Hol a határ? Kampánystratégiák és kampányetika 2002. (szerk. Sükösd Miklóssal) Irodalom Kiadó 2002

8. Kronológia, Magyar médiahelyzet, Századvég Kiadó, 2005. o.274

9. Magyarország Alaptörvénye (2011. április 25.) https://net.jogtar. hu/jogszabaly?docid=a1100425.atv

10. 2011. évi CXII. Törvény MAGYAR KÖZLÖNY 88. szám2011. július 26., kedd

11. 2010. évi CIV. Törvény

12. ОБСЕ обеспокоена новым венгерским законом о СМИ https:// www.dw.com/ru

13. Péter Bajomi-Lázár. A patrónusi-kliensi médiarendszer. Magyarország 2010-2018 (Budapest: Napvilág Kiadó, 2020, 217 oldal).

14. Magyar Naracs, 2010. 12. 11.

15. Nepszabadsag, 2010. 12. 22.

16. Що таке «неліберальна демократія» і як її запроваджують в Угорщині? https://uifuture.org/publications/24443-neliberalna-demokratiya/

17. Власти Венгрии ввели в стране цензуру https://enta.ru/ articles/2011/01/11/tsenzura

18. Szőcs László: Nem száll le Washington az Orbán-kormányról, 2011.07.27. http://nol.hu/kulfold/nem_szall_le_washington_az_orbankormanyrol (Utolsó letöltés:2013.06.22.)

19. Sajtoszabadsag-iranyelvet, bruxinfo.hu, 2013 01.21. https:// bruxinfo.hu/cikk/20130121-kroes-meg-nem-elegedett-mediatorvennyel

20. Kroes, bruxinfo.hu, 21.01.2013

21. ОБСЕ обеспокоена новым венгерским законом о СМИ https:// www.dw.com/ru 


\section{8. Медіаполітика за часів урядування Фідес - УГС в Угорщині}

На виборах 1998 р. УСП, здобувши більше голосів, ніж будь-яка інша партія, програла вибори об'єднаній опозиції на чолі з СМД - УГП. Прем'єр-міністром став її лідер В. Орбан. Віктор Орбан - політик нового покоління. Він народився 1963 р. У 1987 р. закінчив юридичний факультет Будапештського університету (кафедра держави і права). У студентські роки виявляв значну політичну активність, редагував студентський суспільно-політичний журнал. Після здобуття освіти до 1988 р. - співробітник Інституту підвищення кваліфікації Міністерства сільського господарства і продовольства. У вересні 1989 р. за стипендією Фонду Сороса виїхав вивчати історію англійської політичної філософії в Оксфордському університеті. Однак на початку 1990 р. у зв'язку з наближенням парламентських виборів достроково повернувся в Угорщину [1].

Свою політичну діяльність Віктор Орбан почав як член-засновник партії Фідес (Fidesz; абревіатура від Fiööatal Demokraták SZövetsége, «Союз молодих демократів»), створеної 30 березня 1988 р. Він отримав загальнонаціональну популярність виступом 16 червня 1989 р. на церемонії перепоховання Імре Надя та інших політичних діячів Угорщини, страчених у 1958 р. У своїй промові Орбан зажадав проведення вільних виборів $\mathrm{i}$ виводу радянських військ з угорської території.

У 1990 році, на перших виборах у посткомуністичній Угорщині, Орбан був обраний депутатом парламенту (знову обирався в 1994, 1998, 2002, 2006 роках). У 1990 р. став лідером «Фідес», яку під його керівництвом було реорганізовано з ліберальної політичної організації (члена Ліберального Інтернаціоналу) 
в правоконсервативну партію. 31995 р. партія Орбана офіційно називається Fidesz - Угорська громадянська партія (УГП). 3 жовтня 2002 р. Орбан, поряд з керівництвом «Фідес», є віцеголовою Європейської народної партії, до складу якої входять консервативні партії Свропи.

У 1998 р., після перемоги «Фідес» на парламентських виборах (партія отримала 44 \% голосів виборців) В. Орбан сформував правоцентристський уряд. У віці 35 років він став наймолодшим прем’єр-міністром у сучасній Угорщині (й другим у ХХ столітті - молодшим за нього був лише Андраш Хегедюш, який очолював уряд у 1955-1956 рр.). В економічній сфері виступав за зниження податків і соціальних внесків, боротьбу 3 безробіттям та інфляцією. У період роботи його уряду інфляція знизилася з 10 \% у 1999 р. до 7,8 \% у 2001 р. (у 1998 р. вона становила 15 \%). Дефіцит бюджету скоротився з 3,9 \% у 1999 р. до 3,4 \% у 2001 р. Економічне зростання склало 4,4 \% у 1999 р., 5,2 \% у 2000 p., i 3,8 \% у 2001 р. Була відмінена плата за навчання в університетах, відновлені універсальні пільги для матерів [2].

Орбан виступав як прихильник німецької моделі управління, яка передбачає провідну роль прем'єр-міністра у системі влади. Він підсилив роль канцелярії прем'єр-міністра, провів радикальну реформу державного апарату, що призвела, зокрема, до створення суперміністерства економіки. Прагнення Орбана до зниження впливу парламенту на політичні процеси при посиленні особистого впливу прем'єра викликало різку критику з боку опозиції, що обвинувачувала його в авторитарних тенденціях і прагненні чинити вплив на ЗМІ. У період прем'єрства Орбана Угорщина, разом з Польщею і Чехією, в 1999 р. була офіційно прийнята в НАТО.

Він гарний оратор і яскравий полеміст, уміє прихилити до себе аудиторію [3, с. 92]. В. Орбан має багато спільного 3 Д. Хорном. Обидва не бояться труднощів, можуть поразку перетворити на перемогу, піднятися з колін і досягти олімпу, твердо й наполегливо йти до своєї мети. Хорн і Орбан націлені на прийняття рішень та реалізацію влади. Обидва нікому не довіряли, вважали, що існує лише одна система стосунків, у центрі якої їх особистість, і лише від них залежать будь-які рішення, 
справи в державі. Вони вважали політику боротьбою особистостей, а не ідей. Водночас між В. Орбаном і Д. Хорном існують значні розбіжності. Якщо перший керується бажанням, то другий - інтересами. В. Орбану притаманний категоричний стиль правління, він безкомпромісний, жорсткий у прийнятті рішень, прихильник військових дій: напад, швидкість і рішучість - ось принципи його управління. Обстоюючи двополюсну політичну систему - є праві й ліві, на практиці прагне до однополярності: або вони, або ми. Політика В. Орбана розумна і логічна. Він прагне централізованої сильної держави, заснованої на національній самосвідомості та гордості. У своїй зовнішній політиці він скептик щодо Європи й Заходу, розглядає їх як поле для власної боротьби, де потрібно діяти категорично і безапеляційно [4, с. 464].

До кожних переговорів готується грунтовно, кожен його жест ретельно продуманий. Якщо помиляється, то це теж не помилка, а продуманий крок. Навчився використовувати пресу, на відміну від попередників, які або приятелювали, або воювали 3 нею. Він знає, яким має бути вираз обличчя під час інтерв'ю, коли потрібна посмішка, а коли - серйозність. Усвідомив, що прем'єр-міністром недостатньо лише бути, а й треба поводитися відповідно. Стиль роботи В. Орбана, попри молодий вік, вирізнявся винятковою жорстокістю, що межує з диктатом. Не випадково з уряду пішло немало його колишніх соратників по партії, не згадуючи про членів коаліції. Він також був надзвичайно високої думки про себе, що дуже зашкодило йому у виконанні важливих державних функцій. Через цю хворобливу ваду молодого прем’єр-міністра не сприймала й більшість керівників провідних країн світу. В. Орбан за період свого правління так і не виконав більшості своїх передвиборних обіцянок, а програма його діяльності залишилася на рівні декларації. Незважаючи на коаліційну більшість, кадровий потенціал (новий уряд мав змогу використати кадри, які пройшли підготовку в кращих 11 навчальних закладах Заходу) в парламенті, коаліційному урядові за роки правління не вдалося досягти помітних результатів, а в самому уряді частина міністрів, висловлюючи свою незгоду 3 непослідовним курсом В. Орбана, подала у відставку. Загостри- 
лася ситуація і в самій коаліції через те, що керівництво НПДГ незадовільно сприймало авторитарні методи прем'єр-міністра, який ніколи не погоджував своїх рішень принципового характеру не тільки $з$ партнерами по коаліції, а й усередині своєї партії [5].

Після приходу до влади партії Фідес - УГП 29 травня 2010 року прем’єр-міністром Угорщини стає знову В. Орбан. За період, коли він був у опозиції, мало що змінилося в його соціальнопсихологічній характеристиці. Звичайно, він постарішав, став більш виважений та обачливий. Однак, якщо взяти запропоновану українським політологом М. Головатим модель статусу політичного лідера за такими ознаками: функціонально-рольовою; професійною; морально-етичною; самооцінкою [6], то все, сказане раніше, повністю відповідає і сьогоднішньому виміру його нинішніх психологічних якостей. Хоч, як не дивно, популярність партії і їі лідера за понад десять років залишається на досить високому рівні. Тому не випадково партія виграла й наступні дві виборчі компанії.

На сьогоднішній день виконавча, законодавча і судова влада Угорщини поступово зміцнювали зв'язки між собою та правлячою політичною силою, керованою Віктором Орбаном. Тепер ці гілки влади, які повинні бути незалежними, підтримують один одного і Фідес - іноді ненав’ язливо, а іноді відкрито.

Сам Орбан називає такий результат «системою національної співпраці», однак і більш відкрито говорить про «неліберальну демократію». Завдяки цьому систематичному переплетенню повноважень Орбан і його партнери перетворили Угорщину в щось, що нагадує однопартійну державу. Й зробили це без будь-якого насильства і широкої громадської підтримки. Це досягнення погано позначається на свободі Угорщини та їі довгострокових перспективах.

Партія швидко почала використовувати свою більшість і змінила Конституцію. Вона збільшила число суддів у Конституційному Суді з 11 до 15, призначивши чотирьох своїх суддів на нові місця. Потім знизила обов'язковий пенсійний вік для суддів та прокурорів, звільнивши сотні постів для прихильників ФІДЕС. Вона створила Національну судову канцелярію під 
керівництвом однокурсниці Орбана Тюнде Хандо. Хандо може накласти вето на просування по службі й вплинути на те, які судді слухають які справи. У даний час Фідес контролює прокуратуру, Конституційний Суд і Вищий апеляційний суд - курію.

З 2016 року уряд Угорщини також працював над абсолютно новою системою адміністративних судів, на яку буде мати прямий вплив Міністерство юстиції. Ці суди будуть, зокрема, розглядати суперечки щодо ЗМІ та виборів - областей, в яких звичайні суди все ще час від часу виносять рішення проти уряду. Венеціанська комісія Ради Свропи піддала критиці таку систему, й уряд припинив іiі дію, щоб зберегти своє членство у впливовій групі Європейського парламенту, яка попередила Угорщину про виключення зі складу.

У 2011 році Орбан надав право голосу приблизно двом мільйонам етнічних угорців, що є громадянами Румунії, Словаччини, Сербії та України і які в переважній більшості є виборцями ФІДЕС. Їм дозволено голосувати поштою. У той же час близько 350 тисяч угорських громадян, які проживають на Заході і менш охоче віддають голоси за правлячу партію, повинні голосувати особисто в посольствах або консульствах [7].

Це пояснює, як на виборах у 2018 році Фідес отримала 67\% місць у парламенті, зберігши свою більшість, хоча набрала трохи менше половини голосів виборців. Оскільки система так добре перероблена, партії не потрібно опускатися до фальсифікацій виборців, як це роблять грубі автократії. Їх «система національного співробітництва» є вкрай продуманою. У 2018 році Національне виборче управління визнало недійсними тисячі голосів поштою, оскільки на конвертах була розкрита захисна стрічка. У відповідь уряд скасував закон, що вимагає захисту від несанкціонованого доступу [8].

Правове коригування було використано для придушення повідомлень опозиції. У 2012 році, коли ESMA, іспано-угорська компанія, що розміщує рекламу на вуличних ліхтарях Будапешта, брала рекламу від лівих партій, міська рада заборонила всю зовнішню рекламу в межах п'яти метрів від проїжджої частини. Однак, заборона не поширювалася на кіоски, які належать урядовій рекламній групі. У 2015 році майже збанкрутіла 
ESMA була куплена наближеним до Орбана бізнесменом Іштваном Гаранча, і заборона була негайно скасована.

Незважаючи на свої інституційні переваги, Фідес не змогла б залишитися при владі, якби не була настільки популярною. В агітаційній стратегії партії використовувався економічний популізм: місцева «орбаноміка», яка, вважається, перевершує передбачуваний глобалістський неоліберальний консенсус. Орбан був обраний незабаром після фінансової кризи, коли економіка Угорщини була в занедбаному стані. Падіння форинта - місцевої валюти, викликане кризою, означало, що багато угорців, які брали іпотечні кредити під низький відсоток у швейцарських франках, не могли погасити свої борги. Орбан змусив банки перерахувати заставні у форинтах за вигідними ставками.

Орбаноміка також добре вписується в авторитарний інструментарій. Дослідження, проведене Угорською академією наук, показує, що в багатьох селах майже всі голоси віддані ФІДЕС. Соціолог і колишній Міністр освіти Угорщини Балінт Мадяр стверджує, що держава під управлінням Фідес є засобом захоплення економіки і розподілу потоків доходів серед союзників. Мадяр також називає Угорщину «мафіозною державою».

У 7 розділі було детально проаналізовано 61 параграф нової Конституції Угорщини, яка набрала чинності 1 січня 2012 року, в якому було визначено основоположні принципи діяльності ЗМІ. Також було досліджено прийняті 22 липня 2010 року Закон, що регулює засоби масової інформації та комунікації, і 2 листопада 2010 року Закон про свободу преси та захист медіаконтенту, який отримав назву медіаконституція. Ці нормативноправові документи повністю змінили медіапростір та значно посилили контроль держави за ЗМІ $[9,10,11]$.

У той же час «Фідес» не використовує характерних для будь-якого авторитарного режиму засобів масштабної адміністративної цензури, як і не застосовує прийнятного у м'яких диктатурах - ручного режиму управління за принципом «підтримуємо - терпимо - забороняємо». Цей принцип працював тільки в умовах панування державної власності. У той час поза колом державної власності перебували лише переслідувані владою самвидави демократичної опозиції, публікації яких без- 
посередньо доходили до декількох тисяч чоловік. Після зміни режиму у сфері медіа виникла структура змішаної власності, яка нині контролюється партією «Фідес» за допомогою різноманітних репресивних засобів.

3МI, що знаходяться у власності держави, були поставлені під керівництво партії шляхом прямого застосування владних засобів (призначення комісарів, прямі директиви, цензура). Великі телеканали (RTL Klub, TV2) були деполітизовані (погрозами застосування санкцій, податком на рекламу). Критично налаштовані 3МІ заганялися в «гетто» (третирування з боку влади, відлякування рекламодавців). Тим часом, політична сім'я 3 допомогою державної підтримки та нелегітимного примусу створила власну медіаімперію з приватних 3МI.

Першим керівником Ради у справах 3MI, а також Національної ради з питань 3МІ та комунікацій (НРСК), створеної відповідно до нового Закону про ЗМІ в 2011 р., стала довірена особа Орбана, а його наступником - сімейний юрист навколопартійних 3МІ. Його розпорядженнями і постановами регулюється розподіл штучно обмежених через державну монополію ресурсів (частоти мовлення, концесій, дозволів і т. п.), Визначаються правила функціонування медіаринку (критерії діяльності некомерційних 3МI, класифікація програм, часткове обмеження на рекламу й т. п. ) і призначаються санкції. За допомогою преференцій та покарань, заснованих на гнучких правилах, вона може на свій розсуд заохочувати або, навпаки, карати будь-якого учасника медіаринку: відбирати частоту мовлення, виключати 3 тендерів і накладати руйнівні грошові штрафи. У той же час і сама держава побічно, через Фонд підтримки ЗМІ й управління активами (ФПЗМІУ), є ринковим гравцем, до того ж найбільшим, якщо взяти до уваги безперервно зростаючу кількість бюджетних коштів (у 2019 р. - 80 млрд форинтів), що виділяються державним 3МІ (національному інформаційному агентству, радіо і телебаченню) [12].

Новий режим здійснив одержавлення некомерційних 3МI та Угорського телеграфного агентства (УТА), не тільки оволодівши правами власності, а й контролюючи створюваний контент. Їхнє майно і співробітники були переведені у фонд при Раді у 
справах 3МI, була встановлена сувора цензура, й після загальної чистки одержавлених 3МІ в них прийшли віддані режиму кадри, причому іноді допускалися навіть співробітники праворадикальних ЗМІ. За допомогою безкоштовних державних інформаційних послуг був підірваний, практично ліквідований ринок незалежних інформаційних агентств, таким чином держава побічно впливає на зміст інформаційних програм приватних ЗМІ [13].

«Фідес» підтримує лояльні ЗМІ передплатою і рекламними замовленнями державних та муніципальних установ і фірм. У той же час, партія обмежує свободу друку, мінімалізує доходи приватних медіа, побічно контролюючи їх за допомогою позбавлення державної реклами, залякування й «відмов» приватних рекламодавців. Тим самим вони домагаються розорення 3МI, які допускають критику уряду, або принаймні їх відтискування в «резервацію» 3 невеликою аудиторією. Такими, на перший погляд, економічними засобами вдається усувати 3 ринку непокірні 3МI, якщо немає змоги зробити це по-іншому, наприклад, за допомогою прямого адміністративного примусу. Одночасно це деполітизує і найбільші приватні 3МI, змушуючи вдаватися до самоцензури.

Питання не тільки в тому, чи збереглися медіаканали, які дозволяють вільно висловлювати власну думку. Проблема в тому, що влада зуміла витіснити критику в такі замкнуті спільноти, в яких явні опоненти уряду спілкуються лише один з одним, унаслідок чого залишається мало можливостей змінити співвідношення між лояльними і критично налаштованими громадянами в широких верствах суспільства. Критичні 3МI, яких стає все менше і які відіграють роль комунікаційних скандалістів, не зуміли переконати потенційно схилятися до критики режиму виборців за допомогою об'єктивної інформації та зіставлення різних думок, замість цього на адресу уряду щодня, без будьякої саморефлексії вимовлялися одні й ті ж слова критики, що нагадувало своєрідну світську літургію з перебиранням чоток.

Тим часом уряд, підкоряючись своїм інстинктам, за допомогою розподілу ефірних діапазонів грубо ліквідував критичні 3МІ або, влаштовуючи виставу для зовнішніх спостерігачів, 
замкнув їх у гетто вузької аудиторії споживачів-інтелектуалів. Можливо, інтенсивне спілкування у невеликих співтовариствах політично незалежного Інтернету, Facebook'a створює помилкове враження, що незадоволених урядом багато, але насправді обмін думками ведуть одні й ті ж люди і в одних і тих же співтовариствах. Керівники авторитарної держави не доктринери: вони не бояться слів та терпимі до критики, якщо тільки вона не доходить до широкого загалу [14]. Однак, як пише Марія Вашархеі, медіаполіп служить не тільки промиванню мізків, а й відмиванню грошей. Вузькі кола, близькі до влади, є найбільшими постачальниками державних 3MI, будівельниками мережі державних ефірних діапазонів, бенефіціарами державних субсидій і рекламних замовлень, покупцями та засновниками 3MI за державний кошт. Саме вони займають місця тих учасників медіасфери, які витісняються з допомогою нелегітимного державного насильства. Якщо Берлусконі в Італії домігся політичної влади за допомогою власної медіаімперії, то «Фідес» за допомогою політичної влади будує медіаімперію політичної родини. Зрештою, везіння мінливе, і медіаімперія, що знаходиться у власності політичної родини, допоможе пережити мізерні роки, як це вже одного разу сталося до 2010 р. [15].

Будівництво та функціонування медіаімперії «Фідес», створеної після 2010 р., виглядає таким чином:

1) влада ставить на посади, що дозволяють контролювати діяльність державних 3МI, бюджетні ресурси і державну рекламу, своїх людей;

2) вони направляють головну частину державних замовлень і реклами підприємцям, близьким до влади або лояльним до неї 3MI;

3) вони одночасно здійснюють ідеологічну обробку громадської думки і переливання державних коштів у кишені приватних осіб у формі замовлень за завищеними цінами і дивідендів;

4) замикаючи це коло, олігархи, близькі до влади, забезпечують безперебійне функціонування системи за допомогою цілеспрямованих призначень.

Після 2010 р. відносна рівновага у «позапартійному» розподілі державної реклами та оголошень, в якому в основному 
відбивалося співвідношення політичних сил, різко порушилася [16]. В урядовому циклі 2010-2014 рр. спостерігалося потужне прагнення керівників «Фідес» до значного розширення портфоліо 3МI, що знаходяться в безпосередньому володінні партії через близьких ій олігархів. Інакше кажучи, вони домагалися можливості впливати на ЗМІ, не тільки смикаючи за повідець державних рекламних замовлень. Причина цього полягала в тому, що належні до партії ЗМІ (такі друковані органи, як Magyar Nemzet, Magyar Hírlap, Heti Válasz, Helyi Téma, Metropol, а також їх електронні побратими - Hír TV, Echo TV i Lánchíd Rádió) мали вкрай вузьку аудиторію. Винятком була тільки щотижнева рекламна газета Helyi Téma, яка безкоштовно розповсюджувалася по всій країні. Була висунута мета перевести у власність владних структур і значну частину 3МI, що мають вплив на маси споживачів, для яких політика не входить у коло первинних інтересів. Цій меті служило придбання найбільшої, також безкоштовної рекламної газети Metropol, поширюваної на всій території країни. Але справжнім переломом могло б стати придбання двох великих загальноугорських комерційних телеканалів. Раніше вони лише пасивно пристосовувалися до медіаполітики «Фідес». I хоча Закон про ЗМІ наказував їм щоденну трансляцію принаймні 20-хвилинних інформаційних програм, у дійсності ці програми швидше нагадували деполітизовану кримінальну хроніку.

Спроба «Фідес» придбати телеканали у власність виявилася успішною в разі TV2 і невдалою в разі RTL Klub. Найбільший онлайн-портал Origo вдалося примусити до більш дружнього стосовно уряду тону без придбання власності одним політичним тиском, у результаті чого на порталі було розміщено державну рекламу на суму 1 млрд форинтів замість колишніх 250 млн форинтів [17].

Телеканал TV2 отримав від державної реклами 10 млрд доходів, у той час, як у своєму розпорядженні мав більшу аудиторію глядачів, RTL Klub - тільки 500 млн: «Державні витрати на рекламу на телеканалі TV2 зросли в три рази і досягли в 2014 p. суми в 10,6 млрд форинтів, інакше кажучи, кожен третій форинт, витрачений державою на рекламу, став надбанням цього 
комерційного телеканалу. Каналу RTL Klub дісталося набагато менше, всього десята частина доходів TV2, більше того, у другій половині 2014 року ця різниця зросла і стала вже 22-кратною» [18].

На заваді в поглинанні владою телеканалу TV2 стала лише війна між Орбаном та Шімічкою. Спочатку цей маневр здійснювався за участю Шімічки, який тоді ще монопольно контролював медійні зв'язки влади, однак до кінця операції з поглинання телеканалу Орбан уже хотів бачити його власником іншу підставну особу. «В колі керівників «Фідес» було відомо, що Шімічка веде переговори про купівлю TV2. Віктор Орбан уже в четвер увечері отримав інформацію про хаотичність ситуації, що склалася у зв' язку з купівлею-продажем TV2. Один з провідних політиків «Фідес» сказав, що вони почекають кілька тижнів і подивляться, хто переможе в юридичній битві за TV2: Вайна або Шімічка. До тих пір буде відкладено життєво важливе для TV2 рішення про розподіл державної реклами і про введення плати за послуги кабельного телебачення. Вайна купив TV2 в надії на те, що цей телеканал зуміє ще в поточному році урвати собі неабияку частку державної реклами, загальна вартість якої становить 25 млрд форинтів. Через хаотичну ситуацію було відстрочено прийняття урядової постанови, на підставі якої завдяки надходженням від розповсюдження телепрограм доходи TV2 могли б збільшитися на 6 млрд форинтів» [19]. Це визнання означає, що парламентське, державне або відомче рішення відкрито ставиться в залежність від того, чи вдасться залучити TV2 у сферу інтересів влади за допомогою підставної особи. I хоча спочатку здавалося, що Шімічка за допомогою права переважної купівлі випередив Вайну, швидко з'ясувалося, що органи публічної влади, які відіграють визначальну роль на початковому етапі трансакції (Фірмовий суд, Економічне конкурентне відомство), віддадуть перевагу Вайні. Бажаючи надати ваги своїм рішенням, Економічне конкурентне відомство одночасно почало велике розслідування на телеканалі RTL Klub, у якому підозрює у зловживанні домінуючою позицією на ринку [20].

Якщо ж Шімічка виніс би цю складну кризову юридичну справу в міжнародну судову інстанцію, то навіть у разі спри- 
ятливого для нього рішення по закінченні багатьох років йому не дадуть стати власником TV2. У крайньому випадку угорські державні органи, що порушили закон, будуть зобов’ язані виплатити компенсацію. Однак витрати на компенсацію ляжуть не на Вайну, а на угорських платників податків. У той же час, для купівлі TV2 Енді Вайна отримав від державного банку Eximbank кредит у 6,7 млрд форинтів (21 млн євро). Для цього парламенту довелося змінити закон, який регулює діяльність банку 3 підтримки угорського експорту, щоб він надалі міг надавати кредити для здійснення вітчизняних проєктів, не пов'язаних 3 експортом [21].

Схожі закономірності спостерігаються і в функціонуванні зв'язаних з владою фірм, що займаються розміщенням реклами в громадських місцях (Publimont, Mahir Cityposter, EuroAWK).

Описана вище система будувалася навколо двох ключових фігур: прем'єр-міністра Віктора Орбана та головного олігарха Лайоша Шімічки. Перший забезпечував кадрові призначення, парламентські, муніципальні й адміністративні рішення, а також бюджетні ресурси, необхідні для діяльності медіаімперії «Фідес», а другий, частково в якості власника, а почасти в ролі координатора, керував цілеспрямованим розподілом коштів i діяльністю медіаімперії.

Нова перемога «Фідес» на виборах 2014 р. забезпечувала партії збереження необмеженої влади. Віктор Орбан, як про це вже говорилося вище, отримав можливість ліквідувати дуалістичний характер керівництва владою і зробити експліцитно свою роль єдиного лідера. Нижче наводяться ключові етапи позбавлення Лайоша Шімічки ключової ролі в політичній владі, які торкнулися 3МI.

Створення в жовтні 2014 р. Національного комунікаційного управління (НКУ) означало централізацію в двох напрямках. 3 одного боку, управління в обов'язковому порядку об'єднало та монополізувало комунікаційні завдання всіх державних і урядових органів, а також фірм, які частково або повністю належать державі. 3 іншого боку, воно стало займатися пов'язаними 3 цими завданнями: ринковими угодами й замовленнями. Тим самим, унеможливлюючи роботу автономних ринкових меха- 
нізмів, воно, в той же час, «одержавлювало» все своє оточення і знищувало можливість і без того рідкісних сепаратних операцій усередині владних структур. Ця установа прагне не тільки в широкому сенсі визначати суть комунікації державних установ та фірм, а й керувати їі процесом, а також одноосібно приймати рішення про пільги різним гравцям медіасфери, якою нездійсненною не здавалася ця задача. Завдяки цьому йому практично вдалося вивести з гри кілька пов'язаних з владою, насамперед 3 Лайошем Шімічкою, медіа-агентств, за допомогою яких державна реклама розподілялася між різними, в тому числі недержавними, друкованими органами.

Концентрація управління фінансованих державою комунікацій у руках Орбана одночасно означає, що комунікація держави переключилася в режим перманентної виборчої кампанії. Причому за допомогою цього паралельного каналу контролю i впливу піддаються не тільки комунікація державних установ, а й їх діяльність. Подібна централізація означає подальше обмеження і без того урізаної автономії державних установ.

- Намір поставити в залежне становище і обмежити вплив медіа-агентств, пов'язаних з головним олігархом Лайошем Шімічкою й іншими «друзями влади», супроводжувався вже згаданим вище явищем ліквідації привілейованого становища 3MI, які перебувають у власності влади, при розподілі державної реклами і державних коштів.

- Головною метою введення селективно прогресивного податку на рекламу було не що інше, як покарання і можливе витіснення 3 угорського медіаринку найбільшого комерційного телеканалу RTL Klub, який вчинив опір при спробі купити його за допомогою насильницьких методів. Міжнародні зв'язки RTL Klub дали можливість підняти кинуту рукавичку: деполітизований тон інформаційної програми каналу змінився на різко критичний стосовно уряду, в результаті чого глядацька аудиторія програми протягом кількох місяців збільшилася вдвічі, і вона стала найпопулярнішим випуском новин на угорському медіаринку. Сприяючи виходу критики уряду з тісного гетто опозиційних 3МI з аудиторією в кілька сотень тисяч осіб, RTL Klub став однією з найголовніших причин того, що протягом трьох 
місяців «Фідес» втратила третину своїх прихильників. Політика «Фідес» не змінилася, змінився лише ії комунікаційний контекст, доступний широкій громадській думці. у ході медіавійни 3 каналом RTL Klub уряд погрожував тим, що за допомогою поправки до Закону про медіа зруйнує план керівництва телеканалів компенсувати збитки від податку на рекламу за допомогою плати, яка збирається 3 компаній кабельного телебачення за ретрансляцію телепрограм. Зрештою, «Фідес» змушений був відмовитися від проєкту змін до закону, більше того, перед візитом Ангели Меркель до Будапешта в лютому 2015 року було терміново укладено угоду з керівництвом RTL Klub про скасування прогресивності податку на рекламу. Здається, поки ця домовленість не призвела до пом'якшення критичного стосовно уряду тону інформаційної програми каналу.

- 32015 р. «Фідес» зосереджує зусилля на експансії державних 3МІ. Безпосередні бюджетні субсидії державним 3МІ та інформаційному агентству зросли з 47 млрд у 2010 р. до 80 млрд форинтів. Канал М1 Угорського телебачення перетворили в інформаційний, тим самим зробивши марними політичні послуги каналу Hír TV, який належить до сфери інтересів Лайоша Шімічки. У свою чергу, цей олігарх, який у якості відповіді на введення податку на рекламу не став транслювати виступ Віктора Орбана під час літнього табору в трансильванському курортному селищі Тушваньош улітку 2014 р., коли Орбан проголосив будівництво «неліберальної держави». Канал М2 удень транслює дитячі програми, а звечора до світанку функціонує як державний розважальний канал для молоді. Канал Duna TV узяв на себе трансляцію програм, які раніше йшли на M1. У 2015 р. були ще запущені спортивний канал (M4), Будапештський регіональний канал (M5) і тематичний канал (M6).

Суть змін у порівнянні з попереднім урядовим циклом у тому, що ті 3MI, які належать державі, перетворені в медіа 3 необмеженим бюджетом, вони здійснюють демпінг медійних послуг та прагнуть охопити всі жанри і вікові групи аудиторії й керовані безпосередньо, без всяких проміжних інстанцій. Великі комерційні телеканали купуються (TV2) або ж робляться спроби витіснити їх з ринку за допомогою державного приму- 
cy (RTL Klub). У той же час влада скасувала власну приватну медіа-імперію, і колективне сімейне керівництво змінилося безпосереднім одноосібним керівництвом Орбана.

Управління новими проурядовими приватними ЗМІ здійснюється нещодавно створеним 3АТ Modern Média Group, двома власниками якого є Арпад Хабон, довірена особа прем'єрміністра, що підтримує свій матеріальний добробут з надійних, але невідомих джерел, і Тібор Дьорі, який раніше працював у кабінеті прем'єр-міністра в якості, як іронічно говорилося, «держсекретаря у справах Орбана». Як писали журналісти інформаційного сайту 444, «два Распутіна Віктора Орбана почали наступ на угорський медіаринок за допомогою спільної фірми» [22], матеріальна база якої вкрай туманна, оскільки жоден 3 власників, ні «безробітний» Хабон, ні держслужбовець Дьорі, не може володіти капіталом, необхідним для заснування такої фірми. Правда, можна б сказати, що nomen est omen, так як назва Modern Média носила одна з близьких до «Фідес» фірм, яка в 1998 р. «пропала безвісти», залишивши після себе значні борги державі. Нова проурядова медіа-імперія планує почати свою діяльність із запуску одного сайту для обговорення суспільних питань, одного сайту новин бізнесу, одного безкоштовного напівбульварного тижневика i, можливо, однієї радіостанції [23].

«В одному з інтерв'ю Віктор Орбан заявив: умовою суверенітету будь-якої країни є те, що для впливу на громадську думку ЗМІ повинні знаходитися в основному в руках вітчизняних власників, проте в Угорщині ця умова поки ще не виконана. Єдиний сенс закону, націленого на скасування медіа-агентств, полягає в розчищенні простору між власниками ЗМІ та рекламними фірмами. Необхідно знищити все, що створює перешкоди організаціям, які посилаються на професійні аргументи (де має сенс розміщувати рекламу) і займаються перевіркою (чи була опублікована реклама). Ці фірми, оптимізатори, медіа-агенції та сейлз-хауси утворюють систему стримувань і противаг у медіаіндустрії. Без них важко контролювати виконання замовлень, тобто публікацію реклами, і немає значення, наскільки велика аудиторія того чи того ЗМІ. 
Зачистка проводиться не за методом полювання, а скоріше нагадує атомний вибух. Перекроювання посередині року правил діяльності в промисловій галузі, що функціонує повними річними циклами, подібна ядерній атаці: всі гравці ринку будуть надовго зайняті прибиранням сміття і трупів, нарікаючи й сердячись один на одного. А в цей час під покровом грибовидної хмари з неймовірною швидкістю буде побудована урядова медіа-імперія. Немає часу для багаторічного будівництва, як це було у випадку Mahir, Hír Tv, газети Magyar Nemzet та ін. Ніякої органічної еволюції, тільки сила й закон. Перешкодимо, заборонимо, перепинимо, а комусь і дозволимо. Такими є ключові слова, якими керується влада у медіапросторі[24].

Ці два Закони, про які йшла мова вище, викликали різку критику в Європейському Союзі, всі великі європейські періодичні видання вкрай суворо висловилися про них, вживаючи серед інших і такі визначення, як «шовіністичний». 3 моменту прийняття Закону своє занепокоєння висловили всі найбільші міжнародні інститути - ООН, Рада Європи, ОБСЄ. Ці нові Закони, які набули чинності 1 січня 2011 року, призвели до повного контролю ЗМІ Угорщини з боку уряду, а це, у свою чергу, підриває демократичні цінності та авторитет Свросоюзу .

Найбільший медіадослідник Угорщини Петер Байомі-Лазар вважає, що влада сьогодні може безпосередньо впливати на контент ЗМІ. Крім того, його занепокоєння викликає і неточність низки визначень Закону, що дозволяє по-різному його трактувати .

Наглядовий та керуючий урядовий орган, який опікується 3MI, також отримав право стягувати колосальні штрафи (доходять до \$900 000 для радіо і телебачення) із засобів масової інформації за «незбалансоване висвітлення подій».

Уряд Орбана у своєму прагненні захопити медіаринок пішов далі, було отримано право власності на некомерційні ЗМІ й Угорське телеграфне агентство (MTI), що уможливило контроль над створюваним ними контентом. Відповідно, вся їх власність, журналістські кадри були передані у Фонд при Раді у справах 3МІ, був запроваджений жорсткий контроль влади за змістом і розповсюдженням інформації, друкованої продукції, 
3 цих медійних інституцій були звільнені небажані журналісти, їм на зміну прийшли вірні Фідес кадри, і навіть такі, які поділяли праворадикальні погляди. Уряд упровадив безоплатні державні інформаційні послуги, таким чином було нанесено нищівного удару по ринку вільних інформаційних агентств, що дало можливість владі опосередковано регулювати зміст інформаційних конвентів приватних 3МI.

Урядова коаліція знайшла ще один спосіб впливати на 3МI, так, видання, лояльні до влади, отримують від державних і муніципальних закладів рекламні замовлення. У той же час, ті медіа, які критикують уряд, автоматично потрапляють у немилість, їх позбавляють державної реклами, доходить навіть до того, що здійснюється тиск на приватних рекламодавців 3 тим, щоб вони не співпрацювали з цими 3МI.

Таким чином, Фідес карає своїх опонентів, добиваючись їхнього банкрутства або позбавлення їх читацької аудиторії. Якщо ці економічні методи не допомагають витіснити з медіаринку непокірні 3МI, в хід іде адміністративний примус. У свою чергу, найбільші приватні 3МI, розуміючи всю небезпеку інформаційного протистояння владі, змушені вдаватися до самоцензури.

Отже, всі ці урядові дії значно зменшили медіаканали, які безбоязно висловлюють свою думку. Відповідно, суспільство було позбавлене інформаційних ресурсів, що правдиво повідомляли про політичну, економічну та гуманітарну ситуацію в країні. Вдало організована пропаганда уряду Орбана збільшує кількість лояльних до влади громадян та зменшує число критично налаштованих у широких верствах суспільства. Прискіпливі масмедіа, яких стає все менше, мають незначний вплив на виборців, їх критика суспільного ладу за допомогою об'єктивної інформації і зіставлення різних думок не доходить до масового читача. Чи не у цьому причина електорального успіху коаліції Фідес - Угорський громадянський союз - Християнськодемократична народна партія?

Загальновідомим є факт, що влада будь-якої країни має у своєму розпорядженні специфічні інструменти для впливу на населення. Підконтрольні 3МІ - один із класичних прикладів. Однак різниця між державами полягає у балансі провладних, 
опозиційних та повністю незалежних видань і каналів. Якщо донедавна хоча б видимість такого балансу ще зберігалася в Угорщині, то після останніх виборів зникла остаточно.

За даними міжнародної організації «Репортери без кордонів», індекс свободи преси пішов у круте «піке» після нового приходу Орбана та керівної угорської партії «Фідес» до влади у 2010 році. Усього за кілька років Угорщина спустилася з 23-го (2010 р.) на 56-те (2013 р.) місце і продовжує падіння[].

У сьомому розділі ми писали про те, як було знищено одну iз самих популярних угорських газет Népszabadság. Так от, менш ніж за місяць після закриття цього часопису, Mediaworks було продано компанії Opimus Press Plc., фактичним власником якої є давній футбольний друг Орбана Лорінц Месарож (Lorinc Meszaros).

Mediaworks Hungary Zrt - це угорська медіакомпанія, заснована в 2014 році, видавець кількох газет, журналів та вебсайтів в Угорщині. Заснування компанії відбулося завдяки об'єднанню Ringier Kiadó Kft., що належить швейцарському Ringier, та Axel Springer-Budapest Kiadói Kft., яка має німецьке походження. Злиття їхніх угорських дочірніх підприємств у 2010 році не було схвалене Угорською радою з питань медіа й Угорським органом з питань конкуренції $(\mathrm{GVH})$ через надмірний політичний вплив та вплив, який спотворює економічний ринок компанії, що виникає в результаті цього об'єднання [25]. Тому обидві міжнародні компанії повинні були відмовитися від своїх угорських підприємств: 23 січня 2014 року частина їхнього медіапортфоліо була продана австрійській компанії Heinrich Pecina, яка є частиною Vienna Capital Partners (VCP) [26]. об'єднала свої інтереси з угорськими 3MI, i Mediaworks була створена 1 жовтня 2014 року.

Видавнича група об’єднала кілька компаній, включаючи всю власність на колишнє видавництво Ringier, Axel-Springer Hungary, Népújság, Petőfi Népe, Zöld Újság, журнали Julius i більшість прав власності на Népszabadság Zrt. До видавничої групи також входять колишня друкарня Ringier Nyomda (Budatétényben, a Harbor Parkban) та MédiaLog, яка розповсюджує передплатні газети[27]. 
31 червня 2015 року Mediaworks Hungary Zrt. та іï дочірніми компаніями керував Balázs Rónai. 3 початку березня 2015 року тижневик Fanny мав оновлений вигляд і виходив щосереди. Mediaworks майже вдвічі збільшила кількість примірників журналів. Наприкінці березня 2015 року видавець запустив новий телевізійний журнал під назвою Tvmüsor.hu. У квітні 2015 року вийшов журнал преміум-класу для дому Lakáskultúra. У травні 2015 року Mediaworks оновила свої регіональні газети [28].

30 вересня 2016 року компанія придбала Pannon Lapok Társasága Kiadói Kft. (PLT) від Ost Holding GmbH, угорської дочірньої компанії німецької Media Fun Group (раніше WAZ). Окрім усього іншого, вона стала видавцем ще чотирьох провінційних та міських часописів (Fejér Megyei Hírlap, Napló, Vas Népe, Zalai Hirlap та Dunaújváros Hírlap).

25 жовтня 2016 року Opimus Press Zrt. купив 100\% акцій компанії [6]. За Opimus Press Zrt багато людей підозрювали Лерінка Месароса, бізнесмена, близького до керівництва Фідеса, але він заперечував, що придбав Mediaworks. Новим генеральним директором став власник щоденного журналу Hungarian Times Габор Ліскай.

2 червня 2017 року HVG написала, що додаток до річного звіту Magyar Idők Kiadó Kft за 2016 рік заявляє про те, що Габор Ліскай, 100\% власник Magyar Idők Kiadó Kft., хоче продати компанія Mediaworks Zrt. [10]. Magyar Idők Kiadó Kft. за один рік збільшив дохід від продажів майже на 1,5 мільярда фунтів та досяг 2,4 мільярдів фунтів, тому в 2016 році він зміг задекларувати прибуток до оподаткування в розмірі 375 мільйонів фунтів [29].

9 квітня 2020 року Габор Лізской заявив про свою відставку 3 посади голови Mediaworks, яка була прийнята15 квітня 2020 року. Його наступником став Ласло Сабо.

Таким чином, напередодні чергових виборів у квітні 2018 p. Орбан створив комплексну систему ЗМІ, яка успішно діяла по всій країні, забезпечуючи Фідес електоральну підтримку. Паралельно з цим влада проводила постійну боротьбу з опозиційними масмедіа. 11 квітня 2018 року перестала існувати опозиційна газета Magyar Nemzet, яка заснована у 1938 році і 
користувалася великою популярністю у населення. Така ж доля спіткала й радіостанції, зокрема Lánchíd Rádió, яка також була заснована у тому ж році. А вже на початку липня цього року популярний антиурядовий ТВ-канал «НirTv» та вся медіагрупа, до якої він входив, стали власністю Золтана Нєргеш, одного 3 поплічників В. Орбана.

Усі вищеперераховані 3МI належали соратнику та другу прем’єр-міністра Лайошу Шімічці. Проте у 2014 р. їх шляхи розійшлися й останній перекинувся на бік опозиційної партії «Йоббік», відповідно і підконтрольні йому ЗМІ розпочали гостро критикувати урядову коаліцію на чолі з Орбаном. Однак після того, як на чергових виборах «Фідес» отримав 2/3 голосів і четвертий раз залишився при владі, Шімічка зрозумів, що боротися з Орбаном немає ніякого сенсу.

«HirTv» був лідером опозиційних телеканалів. Після того, як він потрапив у медіа-імперію Орбана, на каналі було припинено трансляцію головної програми новин, яку дивилися сотні тисяч глядачів, тому що в ній говорилася правда про соціальнополітичну ситуацію в країні, розкривалися таємниці корупційних дій членів правлячої коаліції.

Так, Орбан припинив діяльність одного з останніх своїх опонентів у медіасфері. Безперечно, окремі опозиційні видання, як, наприклад, інтернет-портали index.hu чи 444.hu, ще прагнуть чинити опір існуючій владі. Але 3 кожним днем це робити все тяжче і тяжче, адже членів Ради медіа, державного органу, який стежить за процесом монополізації медіа, було призначено на посади «Фідес» ще у 2010 році. Відтоді вони незмінно діють на іiі користь [30].

У найпопулярнішого угорського онлайн-видання Index також змінився власник. Точніше власники. Ними стали Йожеф Олтян та Габор Ціглер. Зрештою, угорський медіахолдинг продають уже не вперше, адже він є доволі успішним медіабізнесом.

Однак, ця новина відразу ж стала однією з головних в Угорщині, й причин на це $є$ кілька. Перша - серед нових власників Index 3'явилася «випадкова» людина, близька до влади. Це Йожеф Олтян. Хоча таке в історії Index траплялося і раніше. 
Не так давно медіахолдингом володів епатажний угорський олігарх Лайош Шімічка, про якого ми писали раніше.

Друга i, мабуть, головна причина, чому новина про зміну власників Index стала резонансною, така: за схожою схемою через купівлю/продаж і зміну власника - команда Віктора Орбана захоплювала або знищувала інші провідні медіа Угорщини.

Наразі редакція Index заявляє, що зберігає незалежність та продовжує працювати, а також запустила краудфандингову кампанію.

За схожим сценарієм у 2015-му році популярне інтернетвидання Origo, яке тоді навіть конкурувало 3 Index, змінило власника, а разом з ним і редакційну політику. Через це виданню довелося відключити на сайті коментарі - читачі різко висловлювалися на адресу редакції та нових реальних власників.

Отже, у 2011 році з'явився фонд під назвою Media Services and Support Trust Fund, або просто MTVA, який інтегрував усі державні ЗМІ. Під одним дахом зібрали шість телеканалів M1-M5 та Duna, сім радіостанцій на чолі з KOSSUTH Radio, дев'ять вебпорталів на чолі з Hirado та головну інформаційну агенцію країни MTI, яка стала монопольним першоджерелом.

Під цього «монстра» відтоді виділяються неймовірні бюджети. Так, у 2017 р. це було 80 мільярдів форинтів, тобто $\$ 275$ мільйонів.

Масштаби УТА вражають: величезний штат, ошатні офіси, сучасні студії та обладнання. Та у цього «суспільного» монстра $\epsilon$ брат-близнюк, хоч і не такий виразний та ззовні більш розпорошений.

Ідеться про медіа-імперію з приватних 3МI, які належать найближчому оточенню Віктора Орбана (зазвичай через підставних осіб) і повністю контролюються його людьми.

До 2014 р. ï будував Лайош Шімічка, що особисто володів багатьма впливовими медіа. Однак після того, як він посварився 3 найкращим студентським другом Віктором Орбаном, той почав активно будувати приватну медіа-імперію через інших людей. У ній фігурує чимало різних прізвищ, серед них: Лорінц Мейсарош, Арпад Хобонь та Антал Роган.

Перші двоє за останні чотири роки скупили значну кількість 
угорських 3MI, при чому цілими холдингами, а також створили нові. До прикладу, саме Арпад Хобонь заснував пропагандистський портал 888.hu як альтернативу відверто опозиційному виданню 444.hu.

Та більш помітний у цій справі Лорінц Мейсарош - голова села Фелчут, що неподалік Будапешта. Саме в цьому селі виріс Віктор Орбан, і саме Лорінц Мейсарош, після сварки угорського прем'єра з Шімічкою, раптово почав багатіти. При чому швидше, ніж Марк Цукерберг. А з 2016 р. - ще й скуповувати медіа: Echo TV, TV2, практично всі регіональні 3МI.

Сьогодні легше назвати, яке угорське медіа не належить оточенню Віктора Орбана, ніж навпаки, бо таких залишилися обмаль.

Однак мало створити монстрів. Ними ще треба вміти керувати. Якщо поглянути на результати останніх угорських виборів, можна впевнено сказати, що Анталу Рогану це вдається чудово. Не випадково його називають міністром пропаганди, хоча офіційно він очолює кабінет угорського прем'єра.

Саме Антал Роган відповідав за медійну частину кампанії «Фідес», а вона точно ввійде в підручники з політології та піapy. Річ у тім, що завдяки цим «монстрам-близнюкам» команді Віктора Орбана вдалося фактично створити симулякри ворогів, змусити Угорщину в них повірити і зрештою перемогти цих ворогів, знову здобувши 2/3 місць у парламенті.

Мігранти, Сорос та брюссельська бюрократія - це тріо «головних ворогів Угорщини», про яких інформували 24/7 усі близькі до партії влади медіа, починаючи з 2015 року. А п’ять останніх і поготів. Це триває досі.

Цей скрін головної сторінки сайту Origo став одним із мемів останньої виборчої кампанії у ЗМI. Пропагандистська машина Антала Рогана діяла брутально та цинічно, але неймовірно злагоджено та масово.

Наприклад, уже після виборів угорський тижневик «Figyelő» опублікував список «найманців Сороса», до якого увійшли 200 осіб: науковці, експерти, журналісти та правозахисники, які критикують владу.

Таким чином, минула виборча кампанія в Угорщині остаточ- 
но розколола і суспільство, і медіаспільноту - хто за владу, а хто проти. Про ЗМІ вже не говорять як про незалежні чи об'єктивні, а лише як про ліберальні чи консервативні, опозиційні чи провладні, партійні або комерційні.

Незалежні та об'єктивні 3МІ не потрібні Угорщині Віктора Орбана. Та й журналісти з більшості угорських ЗМІ не хочуть бути об'єктивними та незалежними. Вони прагнуть захищати свою країну від ворогів разом із Віктором Орбаном. Такий вектор розвитку угорський прем'єр назвав неліберальною демократією.

Отже, те, що, починаючи з 2011 р., Freedom House постійно знижує рейтинг свободи ЗМІ в Угорщині, - це закономірність, частина «плану» Віктора Орбана.

Власне як і звіт Саргентіні - документ, підготовлений представницею Нідерландів Джудіт Саргентіні про ситуацію в Угорщині. За нього 12 вересня цього року проголосували в Свропарламенті. Це означає, що проти Угорщини розпочнуть санкції за порушення базових цінностей СС. Чимала увага у звіті приділена й угорським медіа: серед іншого Саргентіні згадує і про монополізацію інфопростору. Хоч у Віктора Орбана цей звіт назвали «кваліфікованою брехнею», в Будапешті прекрасно знають, про що йдеться. Монополізація інформаційного простору Угорщини триває досі.

Такі тенденції в Угорщині протягом останніх восьми років спонукали Держдеп США в листопаді минулого року виділити грант на \$700 тисяч. Ці гроші мали піти на підтримку незалежних 3MI у країні. Утім, як інформує New York Times, команді Віктора Орбана все ж вдалося відохотити Вашингтон від цієї ідеї та направити кошти на інші проєкти. Це був би не менш гучний сигнал, ніж рішення Свропарламенту на користь звіту Саргентіні.

Ні цей провал у Страсбурзі, ні звіти Freedom House не змусять Віктора Орбана відмовитися від ідеї тотального контролю за медіа. Зважте самі: після виборів минуло вже декілька років, а рейтинг «Фідес» не падає і тримається на рівні 40\%.

Тому Віктор Орбан без зайвих докорів сумління продовжує монополізувати угорські медіа та розбудовувати в Угорщині 
«неліберальну демократію», в якій ЗМІ - це передовсім вартові режиму, а не його контролери й критики [31].

У 7 розділі ми вже писали про те, що політика Орбана у медіасфері зустрічає супротив як у середині країни, так і за кордоном. Нещодавно у Будапешті відбувся багатотисячний мітинг проти утиску преси. Угорщину різко критикують в ООН, ОБСЄ, PЄ, СС за спроби перешкоджати діяльності опозиційним ЗМІ.

Ось у цьому є квінтесенція медіаполітики за часів урядування Фідес - УГС в Угорщині. Прем'єр-міністр Угорщини Віктор Орбан значну увагу приділяв і приділяє контролю за засобами масової інформації, оскільки вони відіграють визначальне місце у політичному житті країни. У кого в руках масмедіа, у того в руках і влада. Тому за десять років перебування у владі Орбан створив свою медіа-імперію, до керування якої він не допускає навіть своє близьке оточення. Зрозуміло, що це не тільки засіб пропаганди, але і джерело значних прибутків. Тому який би внутрішній чи зовнішній тиск не здійснювався на В. Орбана 3 приводу його медіаполітики, він не піде ні на який компроміс у цьому питанні й буде проводити свою лінію до тих пір, поки буде знаходитися при владі.

\section{Література}

1. Віктор Орбан. https://uk.wikipedia.org/wiki/ Вiктор_Орбан

2. Д.Ткач. Влада та опозиція в Угорщині - зміна облич чи зміна курсу? / Д. І. Ткач // Наукові записки Інституту політичних і етнонаціональних досліджень ім. І. Ф. Кураса НАН України. - 2014. - Вип. 2. - С. 75-90. - Режим доступу: http://nbuv.gov.ua/UJRN/ Nzipiend_2014_2_8

3.Усиевич М. А. Десятилетие реформ в Венгрии. 90-е годы ХХ в. // Новая и новейшая история. - 2002. - № 5. - С. 80-97.

4. Magyarország évtizedkönyve. A rendszerváltás (1988-1998). 1. Kötet. - 620 o.; 2. Kötet. - 502 o. - Bp.: DKMKA, 1998.

5. Ткач Д. Сучасна Угорщина в контексті суспільних трансформацій: Монографія. - К.: МАУП, 2004. - 480 с.

6. Головатий М.Ф. Політична психологія: Навч.-посіб. - К.: МАУП, 2001.- С. 66-67.

7. Це нагадує антиутопію. Як Віктор Орбан знищив угорську де- 
мократію - The Economist https:/nv.ua/ukr/world/countries/viktororban-i-demokratiya-v-ugorshchini-novini-svitu-50040407.html

8. Перемога вічного Орбана: як угорський прем'єр зберіг абсолютну владу в країні https://www.eurointegration.com.ua/ articles/2018/04/9/7080095/

9. Magyarország Alaptörvénye (2011. április 25.) https://net.jogtar. hu/jogszabaly?docid=a1100425.atv

10. 2011. évi CXII. Törvény MAGYAR KÖZLÖNY 88. szám2011. július 26., kedd

11. 2010. évi CIV. Törvény

12. Szirmai É. (2019) A digitális identitás titkos jelei. In: Balázs G., Minya K., Pölcz Á. (szerk.) A titok szemiotikája. Budapest: Magyar Szemiotikai Társaság. P. 301-312

13. Szirmai É. (2017) A hatalom nyilvánossága a hálózatosodás korában. In: Lőrincz, I. (szerk.) «Semper Reformare» XX. Apáczainapok Nemzetközi Tudományos Konferencia. Széchenyi István Egyetem Győr. P. 397-405.

14. Szirmai É (2019): The secret signs of digital identity. In: Balázs, G., Minya K., Pölcz Á. (eds.): Semiotics of Secret. Budapest: Hungarian Society of Semiotics. P. 301-312. (In Hung.)

15. Vásárhelyi M. A médiapolip müködése - agy - és pénzmosoda. In: Magyar polip - A posztkommunista maffiaállam. Szerk.: Magyar Bálint és Vásárhelyi Júlia. Budapest: Noran Libro, 2013.

16. Hogyan mukodott Orban és Simicska mediabirodálma http:// www.kreativ.hu/databanya/cikk/hogyan_mukodott_orban_es simicska_mediabirodalma

17. Itt a kapcsolat a fidesz és a tv2 eladasa kozo. http://vs.hu/mind/ osszes/itt-a-kapcsolat-a-fidesz-es-a-tv2-eladasa-kozo tt - 0120

18. Itt_vannak_a_számok_igy_befolyaso ljak_orbanek_a_mediat http://magyarinfo.blog.hu/2015/02/05/itt_vannak_a_szamok_igy_ befolyaso ljak_orbanek_a_mediat

19. Nagy-testvér-a-tv2-t-figyeli http://nol.hu/belfold/nagy-testver-atv2-t-figyeli - 156991

20. Raszalltak-az-rtl-klubra http://nol.hu/belfold/raszalltak-az-rtlklubra - 1574503

21. Vajna_közel_7_milliardot_kap_a_tv2-re_az_államtol http:// index.hu/kultur/media/2015/12/15/vajna_kozel_7_milliardot_kap_a_ tv2-re_az_allamtol 
22. Habony-Árpad-elolep-az-arnyekbol-es-media cezar-lesz http://444.hu/2015/04/15/habony-arpad-elolep-az-arnyekbol-es-media cezar-lesz/

23. Eldolt-Habony-lesz-az-uj-Simicska http://valasz.hu/itthon/eldolt -habony-lesz-az-uj-simicska - 111628

24. A_media_elfoglalasanak_haditerve http://hvg.hu/velemeny /20150609_A_media_elfoglalasanak_haditerve

25. Megerősített magyar diplomácia. Magyar Hirlap, XLVII. évf. 134. sz. (2014. jún. 11.) 5. o.

26. Szinte teljes vezetőcsere a külügyi tárcánál.Világgazdaság, XLVI. évf. 196. sz. (2014. okt. 9.) 6. o. VCP

27. Dr. Szabó László. Magyarország washingtoni nagykövetsége (2017) (Hozzáférés: 2019. okt. 1.)

28. Tom Szigeti: New Hungarian Ambassador Presents Credentials to Trump in DC. Hungary Today (2017. szept. 12.) (Hozzáférés: 2019. okt. 1.)

29. Több megoldás kell az energiaellátásban.Világgazdaság, XLVI. évf. 245. sz. (2014. dec. 19.) 5. o.

30. Усі яйця в один кошик - як В. Орбан скуповує медіа Угорщини. https://ua.112.ua/mnenie/usi-iaitsia-v-odyn-koshyk-yak-viktororban-skupovuie-media-uhorshchyny-460250.html

31. Дмитро Тужанський. Вартові режиму Віктора Орбана. https:// medialab.online/news/magyarorszag/ 


\section{9. Електронні засоби масової інформації в Угорщині: сучасний стан}

Історія становлення та розвитку засобів масової інформації налічує більш ніж 320 років. Розпочавшись $з$ першої друкованої газети, масмедіа виросли до сотень мільйонів користувачів завдяки Інтернету. I цей динамічний процес знаходиться у постійному розвитку. 3 цього погляду цікаво буде розглянути, як були започатковані та як розвивалися електронні засоби масової інформації в Угорщині, який їх сучасний стан.

Революційні зміни в систему 3МI, як спосіб поширення, так i форму сприйняття, внесли виникнення аудіовізуальних 3МІ - радіо й телебачення, що додали в передачу інформації звук і зображення. На відміну від друкованих, які спочатку створювалися як спосіб поширення інформації, аудіовізуальні ЗМІ створювалися спочатку як засіб зв'язку.

Таким чином, проіснувавши 320 років, друковані ЗМІ доповнилися участю на інформаційному ринку аудіовізуальними. Протягом наступних 65 років встановилася цілком очевидна i міцна структура засобів масової інформації: друковані ЗМІ газети та журнали й аудіовізуальні - радіо і телебачення. Два види ЗМІ функціонували в громадському ареалі незалежно, не відміняючи, а доповнюючи один одного. Які б нові типи видань або телерадіопрограм не виникали, ця структура здавалася непорушною, ніщо не віщувало глобальних змін у системі.

В умовах прогресуючої глобалізації, в метушні швидко мінливих справ і подій людство не помітило істотне явище - зародження в середині 80-х pp. XX ст. нового виду ЗМІ. Не нового типу видання або радіотелепрограми, а саме виду засобів масової інформації! Їх утвердження в системі ЗМІ варто вважати: 
1985 року - для США, грудень 1992 року - для Угорщини, коли мережеві 3МІ стали звичайним явищем. Новий вид ЗМІ з моменту свого утвердження втілився відразу в трьох формах:

1) інформаційно-пошукові системи;

2) мережеві версії друкованих видань;

3) власне мережеві газети і журнали.

Протягом декількох років система мережевих 3МІ в типологічному відношенні стабілізувалася. Здавалося, нових змін, у всякому разі, функціонального характеру, не передбачається. Однак, вони відбулися: через 15 років, приблизно до 2000-2001 pp. появою в мережі радіо і телебачення. Ще незадовго до цього важко було таке уявити, однак різкий прорив у сфері високих технологій дозволив цьому здійснитися, що призвело до так званої мультимедійної революції. Цифрові технології не просто дозволили створити більш якісний контент, вони створили для ЗМІ нове медіасередовище. Уперше виявилося, що цикл замкнувся - всі засоби масової інформації опинилися в Інтернеті! Й представлені у вигляді онлайн-версій, і чисто мережеві. Знову виникло відчуття, що інтернет-журналістика - це лише форма подання інформації, яка не впливає на сутність змісту. Однак це, безумовно, не так: способи передачі, форми втілення та сприйняття інформації в мережі інші - й у психологічному, і в лінгвістичному, і в соціальному сенсах. Тим не менш, виникло враження стабілізації після 15 років існування електронних мережевих 3МI[1].

П'ятиріччя 2001-2005 рр. внесло суттєві зміни в глобальну систему WWW. Тоді ж, у 2000-2001 рр. почалися пошуки нових шляхів розвитку Інтернету, а точніше - його нової бізнесмоделі. Утім, тоді ж і незадовго до цього вже були створені нові сервіси, значущість яких у той час ніхто ще передбачити не міг.

У 1996 р. двоє аспірантів Стенфордського університету Ларpi Пейдж (Larry Page) i Сергій Брін (Sergey Brin) заснували компанію, названу ними Google. Своїм завданням вони поставили розробку ефективної технології пошуку інформації на підставі аналізу «зворотних посилань» (back links), що ведуть на даний сайт. Самою назвою («гугл» - одиниця зі ста нулями) творці Google хотіли дати зрозуміти, що мета компанії - створити не- 
скінченно величезну базу даних для пошуку інформації. Роботи 3 удосконалення технології тривали, що призвело до створення величезної пошукової бази. Одночасно йшов постійний пошук інвестицій і відкриття власного сервера. У 1999 році Google став обробляти 500 тисяч запитів у день, отримавши світову популярність та, на думку журналу Тіme, увійшов у десятку кращих кібернетичних технологій за рік. До 2001 року Google вже обробляв більше 100 мільйонів запитів у день і став пропонувати безкоштовні послуги пошуку школам, університетам й іншим освітнім установам у всьому світі[2].

У серпні 1999 р. у Сан-Франциско був створений портал Blogger - перший простий безкоштовний загальнодоступний сайт, на якому кожен користувач міг розмістити інформацію про себе. Люди стали розташовувати свої щоденники - поряд 3 особистими або сімейними відомостями, міркування про події, що відбуваються, думки і погляди, іноді супроводжуючи цю інформацію фотографіями. Тоді цьому малопомітному досвіду ніхто великого значення не надав. Однак у трагічний для американців і всього цивілізованого людства день 11 вересня 2001 року, коли терористами були зруйновані «близнюки» - дві найвищі будівлі в світі - 110-поверхові хмарочоси ділового центру в Манхеттені, сотні нью-йоркських користувачів сайту Blogger уперше перетворилися на джерело інформації для офіційних 3МІ. Нью-йоркські автори Інтернет-щоденників вели репортаж 3 місця події про теракти 11 вересня 2001 року: вони описували події, свідками яких стали, публікували фотографії, розповіді очевидців, чутки тощо. Порівнятися з таким потоком інформації, зібраної безпосередньо з місця подій і з безлічі позицій та протягом усього часу, коли відбулися ці події, не змогла жодна світова телекомпанія. На цій основі стали створюватися нові, більш грунтовні сервіси[3].

У кінці 2002 р. увійшла в дію перша пошукова система для блогів й інші технологічні вдосконалення. 32003 р. у США, а потім і в інших країнах блоги стали використовуватися у виборчих кампаніях. Соціально-політичний інтерес при технологічних досягненнях наклався на все зростаючий особистий інтерес пересічних громадян, які прагнуть закріпити інформацію 
про себе. Число блогів стало стрімко зростати, поряд з особистими стали з'являтися блоги спільнот, комунікації між блогами стали вдосконалюватися. Усе це призвело до створення нового середовища, названого блогосферою.

У березні 2000 року в Лондоні кілька ентузіастів створили безкоштовний енциклопедичний мережевий проєкт під назвою «Нупедія» (Nupedia), відкривши однойменний портал. Розвиток цього проєкту знайшов відображення в здійсненні більш масштабної ідеї - створення безкоштовної, яка претендує на всеосяжність, всесвітньої енциклопедії, створеної ентузіастами на добровільних засадах. Новий проєкт, що отримав назву Вікіпедії (Wikipedia), був офіційно відкритий 15 січня 2001 р. Ларрі Сенгером і Джиммі Вейлза. Спочатку це здавалося неймовірною витівкою: кожен міг скласти словникову статтю про що завгодно, а головне - виправити, доповнити або змінити чужу. Вже через місяць у Wikipedia було опубліковано 600 статей, через рік $-20000[4]$.

У 2001 р. співробітники різних інтернет-компаній Кріс ДеВульф і Том Андерсон, маючи досвід роботи з різними сервісами, об'єднали зусилля для створення нового багатоцільового проєкту, який до середині 2003 року вилився у створення спільної компанії MySpace та відкриття однойменного сайту MySpace.com. Ідея проєкту полягала в об'єднанні численних сервісів у одному місці й, відповідно, можливості надання користувачам багатьох послуг одночасно. Творці MySpace поставили собі за мету надати молодіжній аудиторії максимально зручні способи спілкуватися між собою в чатах, обмінюватися фотографіями, музичними та відеозаписами, публікувати статті й замітки, організовувати клуби за інтересами - аж до професійних і соціально-культурологічних товариств. Ця мета була відображена вже в назві: MySpace означає «Мій простір». Та не тільки в рекламних листівках провайдерів, але і в столичних амбітних журналах, і в дисертаціях можна зустріти визначення Web 2.0 як сервіс (!), навіть при наявності посилання на O'Рейлі. Тим часом, він визначив це поняття цілком ясно, навівши його основні принципи, суть яких зводиться до двох головних характеристик: 
1. Масова участь користувачів у пошуку і створенні інформації при розширенні й спрощення зв'язків між ними.

2. Надання користувачам численних послуг різної якості безкоштовно.

Більше того, поступовий перехід на оплату користувачам за надану ними за власною ініціативою інформацію. Уперше для творців сайтів виявилося можливим залежати не від інвестора або спонсора, більш того - не від рекламодавців, а від якості власної роботи. Уперше в історії ринкової економіки виявилося, що можна надавати людям масу послуг, не просити гроші й не турбуватися про рекламу. Така зрозуміла і звична капіталістична модель перевернула все 3 ніг на голову. Вийшло, що творцям треба займатися творчістю, а гроші прийдуть до них самі тільки від того, що число відвідувачів у десятки і сотні мільйонів привернуло потік рекламодавців, спраглих розмістити там свою рекламу за великі гроші[5].Отже, що ми маємо вже після 2005 і до 2010 pp.:

1. Google (Гугл) - перша в світі за визнанням користувачів і обсягом (дві третини світового ринку) пошукова система, що обробляє більше 40 мільярдів запитів на місяць. Лідер пошукових машин інтернету, індексує більше 8 мільярдів вебсторінок. Google може знаходити інформацію на 186 мовах, випустив i надав у безоплатне користування: безрозмірну поштову програмy Gmail, найзручнішу в користуванні; Google Talk, зручну i надійну програму спілкування між користувачами в реальному часі; Google Maps з картами доріг світу й інші сервіси. Сам же Google вже давно не сервіс, а найбільша в світі платформа, в якій десятки сервісів і новітні технології пошуку інформації [6].

2. Вікіпедія. У березні 2006-го року, незважаючи на критику, число статей у Вікіпедії досягло 1 мільйона, а до 2010 р. перевищила 15 млн! Сайт налічує 325 млн користувачів i, за деякими даними, вважається п'ятим у світі за відвідуваністю[7].

3. MySpace («мій простір») - найпопулярніший в Америці сайт і 6-й за популярністю в світі - відразу після Google (серед англомовних). Отримав стрімкий розвиток унаслідок вдалого поєднання комплексу одночасних послуг, що надаються. За два роки після відкриття в 2003 р. чисельність користувачів зросла 
більш ніж у 30 разів, приріст трафіку в 2005 році склав 4300\%! На 2010 р. у ньому зареєстровано понад 200 мільйонів користувачів. Обсяг інформації склав 65 млрд сторінок у день[8]!

4. Блогосфера успішно розвивалася, вдосконалюючись технологічно і входячи в свідомість мільйонів. Згідно зі статистичними даними, на вересень 2009 року в світі налічувалося приблизно 140 млн блогів. До цього числа входили не тільки особисті блоги, які, звісно, становили більшість, а й блоги різноманітних спільнот. Сьогодні, незважаючи на те, що тільки чверть 3 них використовується активно, ця цифра значна і продовжує зростати. Ці сервіси, що виникли ще в період Web-1.0, отримавши завдяки багатьом удосконаленням мільйони користувачів, перетворилися в нову технологію, відповідну Web-2.0. Але після 2005 року, коли принципи Web-2.0 були сформульовані й був досвід вищеописаних сервісів, один за одним почали з'являтися нові сайти, які значно зміцнили основу системи, що сформувалася, підтвердивши своїм народженням іiі життєвість. Наведемо два приклади. YouTube - найдинамічніший сайт в інтернеті: сховище відеороликів про все на світі, які може закачати будь-який бажаючий. Зараз їх там десятки мільйонів, і кожен день закачуються нові десятки тисяч. Гугл купив його в 2006 р. за 181,65 млрд. YouTube 3-й у світі за кількістю відвідувачів - 1 млрд. переглядів на день[9]!

Блогосфера нині сповнена «щоденними газетами» та «щоденними журналами», які часто, в залежності від особистості редактора-видавця, становлять значний суспільний інтерес і користуються популярністю у споживача. Звичайно, одна людина не в змозі замінити творчий колектив журналістів, художників, фотокореспондентів, верстальників, художніх та технічних редакторів, режисерів. Але це і не потрібно: достатньо мати хороший смак та провести серйозну роботу з відбору тематики, проблематики, новинної інформації. Виходить, що талановитий видавець-редактор мережевого ЗМІ вторинної інформації зможе конкурувати з найпотужнішими професійними періодичними виданнями тому, що використовує досягнення всієї світової журналістики.

Нова інформація. Протягом століть інформація росла, під- 
коряючись одному і тому ж закону, - по експоненті, відображаючи такі ж темпи зростання, які супроводжували багато категорій науки, культури, суспільства, а головне - зростання населення планети. Й, уперше в історії, демографічне зростання змінилося, що вплинуло на 3МІ з погляду як структури населення, так і структури інформації. Це серйозне явище, тому що обсяг, характер та сутність інформації для ЗМІ значно змінилися. Насамперед доступ до неї став масовим, реципієнт зрівнявся в правах 3 найбільш просунутим медіамагнатом у сенсі доступності й швидкості їі отримання. Вже давно низка дослідників журналістики говорили про явище нової людини, про те, що на зміну homosapiens приходить homoinformation (homoinformatikus). Здається, це не зовсім так. Людина 3 давніх часів була homoinformation, вона прагнула інформації, хотіла отримувати іï все в більших обсягах і швидше (в кінці XIX ст. щоденної «Нью-Йорк таймс» виявилося недостатньо, стали друкувати по два випуски в день!). При цьому людині завжди здавалося, що інформації багато, а вона, скаржачись на це, хотіла ще більше. Так що справа не тільки і не стільки в зростанні інформаційних потоків. Переставши рости по експоненті, вони не зменшилися в обсязі, навпаки, різко зросли й обплутали людину непередбачуваністю розвитку, неможливістю ефективної диференціації та каталогізації світу таксонів і біт.

Нова людина. Очевидно, що високі технології - це не просто вдосконалення техніки, прискорення процесів отримання й пошуку інформації, вони впливають на саму людину, змінюючи iii. Даючи значні можливості, технологія завжди щось забирала, звужуючи їі творчий потенціал. Так, друковані ЗМІ звузили систему сприйняття світу людиною, надаючи інформацію, оброблену автором, редактором, видавцем. Аудіовізуальні 3МІ в готовому вигляді надали звукове та відеозображення, нав'язуючи людині образи навколишньої дійсності. Мережеві пішли далі: вони дають готові форми на все, що коли б людині не знадобилося, тексти забезпечені ілюстраціями, професійно підготовлені на всі випадки життя - словники та енциклопедії, газети і журнали, курсові та дипломні роботи, реферати для студентів, дисертації, книги й ін. Зрозуміло, що одні люди заробляють 
на праці інших, зрозуміло, що часто одні крадуть у інших. Так було і так буде, оскільки людина недосконала: в ній уміщуються одночасно й божественне, і диявольське. І з цим нічого не поробиш Так чи інакше, але можна з упевненістю стверджувати, що високі технології сформували нову людину, сутність якої ще належить вивчити. Світ вступив у нову добу - час перенасичення інформацією та послугами до такої міри, що, ввійшовши в суспільство споживання, людина повністю втрачає здатність творити, створювати своє, домагатися, шукати, долати. Їй усе дається в готовому вигляді, досвід і результат діяльності мільйонів стають доступні кожному. Сумно, але в будівництво суспільства споживання значний, якщо не вирішальний внесок зробили журналісти. У цих умовах засоби масової інформації повинні виробити нову стратегію свого знаходження в світовому співтоваристві, що стрімко змінюється під напором високих технологій, окремо взятих видів ЗМІ[10].

Тепер перейдемо до розгляду сучасного стану електронних засобів масової інформації в Угорщині. Розпочнем з радіо. У попередніх розділах ми детально вже писали про цей угорський медіаресурс, його історію та розвиток. У цьому розділі зупинимося лише на сучасному стані радіо в країні.

Угорське радіо (відоме на міжнародному рівні як радіо Будапешт) в основному фінансується за рахунок державної підтримки засобів масової інформації, служби та Фонду з управління активами (Médiaszolgáltatás-támogató és Vagyonkezelő). Це урядова організація, утворена в 2011 році, а також громадськими мовниками керує Угорське телебачення і Duna Televízió, a також Угорське телеграфне агентство.

31 липня 2015 року Угорське радіо, а також три інші громадські мовники, які були під керівництвом MTVA були об'єднані в єдину організацію під назвою Duna Médiaszolgáltató. Вона є правонаступником Угорського радіо та активним членом Свропейської мовної спілки [11].

Внутрішні мережі з штаб-квартирою в Будапешті й кількома регіональними відділеннями по всій країні, MR відповідає за суспільне мовлення на всій території Угорської Республіки. А також підтримує дев'ять регіональних студій, корпорація ви- 
робляє три загальнонаціональних угорськомовних радіоканали (Kosút, Petőfi, i Bártok), що охоплює весь спектр надання радіо громадського обслуговування, а четвертий канал (MR4) спрямований на національні меншини країни.

Kosút Rádió - назване на честь Лайоша Кошута, одного 3 лідерів революції 1848 року, канал є офіційною радіостанцією Угорщини. Це флагманський канал Угорського радіо. Створена в 1925 році, станція має більше 3 мільйонів слухачів у день. Вона насамперед транслює новини, в тому числі інтерв'ю, дискусії, доповіді та інші програми [12].

Petőfi Rádió - названа на честь поета Шандора Петефi, також учасника революції 1848 року, станція орієнтована на молоде покоління і транслює сучасну музику [13].

Bártok Rádió - названа на честь композитора Бели Бартока, це станція класичної музики. Вона проводить програму високої культури в доповненні до оркестрової і оперної музики. Ймовірно, лише кілька тисяч людей слухають цю станцію, тому пропозиції про припинення Rádió Барток були зроблені кілька разів, але ніколи не задовольнялися [14].

Nemzetiségi Adások - цей канал радіо транслює програми на мовах національних меншин Угорщини.

Parlamenti Adások - розповідає про діяльність Державних зборів Угорщини, надає слово депутатам, парламентським оглядачам.

Dánkó Rádió - названа на честь Іштван Данко, угорського скрипаля і композитора циганського походження, ця радіостанція транслює регіональний контент по всій Угорщині, грає народну музику й транслює оперети та шоу. Вона доступна цілодобово в Інтернеті й FM.

Безумовно, в Угорщині є безліч приватних радіостанцій, які працюють у FM-діапазоні як у Будапешті, так і в провінції.

Угорське телебачення. Трохи історії. У готелі «Геллерт»м. Будапешт у 1936 році відбулися перші спроби телемовлення в Угорщині. У 1954 році почалося тестове мовлення: в рамках цих експериментів на телеприймачі транслювалися невеликі відеозаписи і фоторяд. 23 лютого 1957 р. тестове мовлення стало здійснюватися на постійній основі, а 1 травня 1957 р. під час 
святкування Дня весни і праці в Угорщині почалося регулярне телемовлення. 2 липня 1957 р. вийшов перший випуск новин телепрограма «Híradó» - новини. 18 серпня разом з Угорським радіо відбулося об'єднання Угорського телебачення в корпорацію «Угорське радіотелебачення» (Magyar Rádió és Televízió, MRT). На його основі з'явилася Міжнародна організація радіомовлення і телебачення, більш відома як «Інтербачення» (в його структуру першими ввійшли ЧССР, НДР, Угорщина i Польща).

Число глядачів у 1959 році досягло 50 тисяч. У 1960 році відкрився телеархів Угорського радіотелебачення. До 1964 року чисельність телеглядачів зросла до 2,7 мільйонів осіб (у середньому від 3 до 5 глядачів на телеприймач). За даними 1965 року, 46\% мешканців Угорщини, які жили в зоні телемовлення, вважали за краще не дивитися телебачення, а читати книги, і 10\% - слухати радіо. У 1966 році по телебаченню були показані 23 театральні постановки в Будапешті та 20 в інших містах, у тому ж році були показані 25 телефільмів і 5 мюзиклів. У 1969 році число глядачів зросло до 4 мільйонів, і в тому ж році почалося кольорове телемовлення: був показаний фільм Бели Бартока «Чудесний мандарин».

Перехід на кольорове телемовлення завершився в 1971 році, в тому ж році почалися тестові трансляції Другого каналу Угорського телебачення. Ця декада стала найпродуктивнішою в історії угорського телебачення, оскільки загальний обсяг телемовлення становив тисячі годин. 12 травня 1974 року Угорське радіо й Угорське телебачення були об'єднані в Державний комітет $з$ телебачення і радіомовлення (Állami Rádió és Televízió Bizottság) [15].

Щорічно обсяг телемовлення становив 4300 годин (по 83 години на тиждень). У 1981 році з'явився сервіс телетексту «Képújság» («Газета 3 картинками»), який став використовуватися у всіх телевізорах. Відкрилися нові телепрограми «Ablak» («Вікно») i «Раnoráma» (випуск міжнародних новин). У 1984 р. відкрився телепередавач у м. Печ, у м. Секешфехервар почалося кабельне телемовлення. Телепрограма RTV стала однією 3 найпопулярніших (1,4 мільйона глядачів щотижня). 
У 1985 році головна лінія політики Угорського телебачення змінилася: запуск теленовели «Рабиня Ізаура» призвів до народження угорських теленовел. 7 травня 1987 р. почали показ телесеріалу «Сусіди» (Szomszédok), який транслювали кожні два тижні по четвергах. До кінця 1980-х років почалися експерименти з переходу на цифрове телемовлення. 31988 року в рамках політики допомоги пенсіонерам особи, старші 70 років, були звільнені від сплати ліцензійного збору, а в тому ж році почалося мовлення іншими мовами (Печ і Сегед). Друга програма Угорського телебачення отримала більші права.

У 1989 році мовлення тривало по п’ять днів на тиждень. Винятки 3 цього правила робилися тільки під час трансляції польоту космонавта Берталана Фаркаша. У 1989 році розпочав мовлення тележурнал «Nap-kelte» («Схід сонця»), який став основною телепрограмою нової телекомпанії «Nap-TV».

Після розпаду СРСР та краху соціалізму в Угорському телебаченні почалися перестановки: низку програм було закрито, а низка провідних журналістів втратили роботу. Керівництво змінювалося стрімко, як і телепрограми. 1 січня 1993 р. MTV увійшло до складу Свропейської мовної спілки. У 1992 році був відкритий приватний телеканал Duna TV, який, однак, співпрацював з УТВ. У тому ж році почалося комерційне кабельне телемовлення в Будапешті. 21 грудня 1995 р. була створена Національна комісія з радіо і телебачення (Országos Rádió és Televízió Testület) [16].

У 1997 році був запущений телеканал TV2 на тій частоті, де транслювався раніше М2, однак УТВ висловив протест проти цього, оскільки боявся втратити аудиторію (міг постраждати і телеканал RTL Klub). У результаті частоту залишили й виділили нову частоту TV2, а M2 став тільки кабельним і супутниковим. Мовлення УТВ-2 велося в тих місцях, де його раніше майже не було, що стало своєрідним гандикапом для компанії.

Основною інформаційною програмою став вечірній випуск новин «Az Este». У той же час були запущені нові програми: науково-інформаційна програма «Delta», а також щотижнева аналітична програма «Ablak». До кінця 1990-х років телекомпанія повністю перейшла під контроль уряду, що викликало по- 
тік критики на її адресу і звинувачення в підтримці проурядової позиції.

Брак фінансування призвів до скорочення і спрощення сітки мовлення. Телекомпанія УТВ стала закритим акціонерним товариством після переходу під контроль уряду. У 2000 році MTV1 було перейменовано в M1, MTV2 - у M2. У 2002 році припинила дію її ліцензія на телемовлення, що поставило телекомпанію на межу зникнення. Сдине фінансування здійснював тільки Уряд Угорщини, що призвело до зниження якості телепрограм.

Масові заворушення, які прокотилися в Будапешті у 2006 році призвели до того, що мовлення тимчасово припинилося, коли бунтівники ввірвалися в будівлю телецентру і тимчасово захопили його. Ще однією проблемою стали постійні спроби закриття то M1, то M2. 1 серпня 2008 року MTV запустило версію телеканалу М2 у стандарті розкладання 1080 i, в 23 грудня - версію телеканалу М1. До 2010 року було продано будівлю телецентру.

Разом 3 тим, УТВ залишається ініціатором багатьох нових телепроєктів: у 2012 році був запущений телеканал M3D, на якому вперше почалося 3D-телемовлення.

1 липня 2015 року MTV, MR, Duna Televízió та Угорське телеграфне агентство були об'єднані в Duna Média (повна назва - Duna Médiaszolgáltató - «Дунайська медіаслужба»)[17].

Фінансування телекомпанії здійснюється за допомогою субсидій від держави і доходів від реклами. Бюджет телекомпанії на 2016 рік становив 19,5 млрд угорських форинтів (приблизно 72 млн євро). Очолюється радою директорів і Генеральним директором. Угорське телебачення $є$ членом Свропейського мовної спілки, з 2011 року активно співпрацює з Угорським радіо [18].

В Угорщині на сьогоднішній день працюють 13 каналів, які транслюються через супутникове телебачення FTA, а також існує розгалужена систем кабельного мовлення. Серед них: загальні й розваги - 19, новини і політика -4 , спорт - 13 , документальні - 30, музика - 15, дитячі - 10, кіно - 25, HD TV - 50, регіональні - 9, для дорослих -1 . 
Таким чином, в Угорщині створена і функціонує потужна система телебачення, провідні телеканали контролюються урядом В. Орбана, $\epsilon$, щоправда, й опозиційні канали, але їх обмаль, і вони не в змозі конкурувати з потужною системою державних електронних 3MI.

Раніше у цьому розділі ми вже писали про те, як Інтернет вплинув на електронні ЗМІ в Угорщині. Лише нагадаємо, що всесвітня павутина народилася в США у 1985 році, в Угорщину вона прийшла у 1992 році. До середини 1980 -х років на захід від Угорщини Інтернет регулярно використовувався науководослідними центрами та університетами, особливо для листування та комунікацій. На задньому плані вже застосовувався протокол ТCP / IP, що використовується сьогодні, під яким телефонні з'єднання та, у випадку локальних мереж, коаксіальні кабелі забезпечували з'єднання. Він був створений як мережа Інтернет-мереж. Слід розуміти, що спочатку університети з'єднували комп'ютери всередині власних будівель та офісів за допомогою серверних машин і HUB, а пізніше ці мережі були з'єднані між собою маршрутизаторами та швидкісними лініями. В Угорщині будівництво національної мережі з комутацією пакетів X.25 було розпочато Posta, MATÁV та Please Kft. 1986 p. 3 організацією Програми розвитку інформаційної інфраструктури (IIF, пізніше NIIF). За цей період Програма фінансувалася Угорською академією наук та Національним комітетом технічного розвитку. Завдяки заборонам СОСОМ у MTA SZTAKI від імені IIF була розроблена масштабна мережева система програмного забезпечення для вітчизняних користувачів. Мережа, побудована в 1990 році, вже пропонувала різні мережеві послуги науково-дослідним інститутам, університетам та бібліотекам 3 тисячами кінцевих точок Х.25.

Зміна режиму в 1989 р. також сприяла поширенню Інтернету в Угорщині. Мережеві пристрої було вилучено зі списку СОСОМ (до 1991 року весь список було закрито). У той час для листування використовувалася програма ELLA. 1990 рік був роком міжнародного відкриття, після з'єднання EARN-BITNET та EUnet було встановлено повноцінне інтернет-з'єднання через Відень. У той же час, у межах країни була побудована магі- 
стральна мережа HBONE, яка вже використовує технологію IP, що з'єднує міські мережі користувачів у столиці й найважливіших регіонах. Асоціація HUNGARNET була створена в 1991 році, та 3 того часу відносини 3 міжнародними організаціями дослідницької мережі поступово розвивалися. 1992 рік народження в Угорщині www. Досі використання мережі в основному було завантаженням файлів і розсилкою файлів, але відтепер пріоритетним стає «серфінг», тобто пошук та завантаження інформації через гіперпосилання. У 1993 році був запущений перший угорський сервер WWW, www.fsz.bme.hu. HUNGARNETNIIF приєднався до Європейської мережі дослідників (DANTE, Доставка передових мережевих технологій в Свропу) як члензасновник. 1995 рік - це важлива дата, оскільки саме тоді починається лібералізація телекомунікацій, Інтернет 3 цього часу став відкритий для широкої громадськості. Відтоді історія також стає двоякою. 3 одного боку, продовжував розвиватися HBONE, який також будувався за допомогою державної допомоги, а з іншого - з'являлися постачальники бізнес-послуг із власною мережею чи орендою.

Давайте спочатку розглянемо HBONE. Слід зазначити, що розширення пропускної спроможності Інтернет-зв'язку як в Америці, так і в Європі стало однією з найважливіших цілей, тому для реалізації було розпочато низку проєктів. Угорщина насправді нічого не робила, крім як приєднатися до цих проєктів, та взяла на себе державне фінансування. HBONE розвивається карколомно: міжнародний вихід 1996 р. 2 Мбіт / с. У 1998 р.: вже європейська швидкість $10+5$ Мбіт / с, вихід із закордонної мережі та швидкість внутрішньої магістралі також складають 2 Мбіт / с.

У 2000 році міжнародна швидкість з'єднання за кордоном 68. Він досяг 34 Мбіт / с (пізніше 155 і 78 Мбіт / с, а в 2001 р. 310 і 155 Мбіт / c), і побудована вітчизняна магістральна мережа 155 Мбіт / с (загальною потужністю 3,5 Гбіт / с). Участь у проєкті NIIF-HUNGARNET, який також підтримується СK, у рамках міжнародного консорціуму NREN, створеного для впровадження GEANT.

Уже у 2002 році швидкість 2,5 Гбіт / с підключення GEANT 
означало потужність міжнародного зв'язку для вітчизняних користувачів, тоді як збільшення швидкості до 2,5 Гбіт / с було реалізоване також у внутрішній магістральній мережі.

Основні провінційні та Будапештські лінії HBONE, а також міжнародні зв'язки мають пропускну здатність 10 Гбіт / с. Інші з'єднання HBONE, як правило, є пропускною здатністю 1 Гбіт / с, а в мережевій магістралі є кілька ліній нижчої швидкості. Для передавання сигналу в основному використовувалися орендовані лінії від постачальників послуг телекомунікацій, i незначна їх частина підключена до установ академічної громади 3 власною інфраструктурою (оптичні волокна, мікрохвильове обладнання). Провінційні та міжнародні гігабітні з'єднання базуються на сучасній технології DWDM, яку вітчизняні постачальники послуг уперше використали для задоволення потреб HBONE в УгорщНа серпень 2020 року Угорщина у галузі інтернет-інфраструктури займає лідируючі позиції в $Є С$, а за використанням Інтернет-сервісів знаходиться в середині серед країн спільноти. У рамках мережевого стовпа DESI Угорщина в 2020 році опинилася на 7-му місці, що на дев'ять місць краще, ніж у 2019 році, й сприятливішому, ніж середній рейтинг конкурентів у Вишеградській групі. У готовності 5G Угорщина має третю позицію в Інтернеті зі швидкістю завантаження не менше 100 мегабіт у секунду.

Серед країн-членів СС Угорщина посідає 14-е місце за рівнем використання Інтернет-послуг, просунувшись на 5 місць порівняно з 2019 роком. Перше місце Угорщина займає у використанні соціальних медіа (86 відсотків населення - користувачі).

Частка угорців, які використовують Інтернет-дзвінки, зросла, внаслідок чого Угорщина посіла 3 місце серед країн-членів ЄС у рейтингу 2020 року. В плані корпоративної інтеграції цифрових технологій, розвитку електронного уряду та цифрових навичок робочої сили Угорщина відстає від середнього значення для СС. У корпоративному інтеграційному рівні цифрових технологій Угорщина посідає 26-е місце, відстаючи від минулого року на два місця. Угорщина просунулася на два місця порівняно з 2019 роком, все одно на 24-му місці в рейтингу[19]. 
Зараз розглянемо, яку роль у сучасній Угорщині відіграє Інтернет. I насамперед проаналізуємо, які платформи соціальних медіа мають найбільше користувачів у країні у 2019 році.

Facebook - одна 3 найкращих платформ соціальних медіа, яку бізнес може використовувати для досягнення свого цільового ринку - незалежно від того, до кого вони належать. Незалежно від статі та віку, давайте подивимося на останні дані користувачів Facebook у 2019 році в Угорщині.

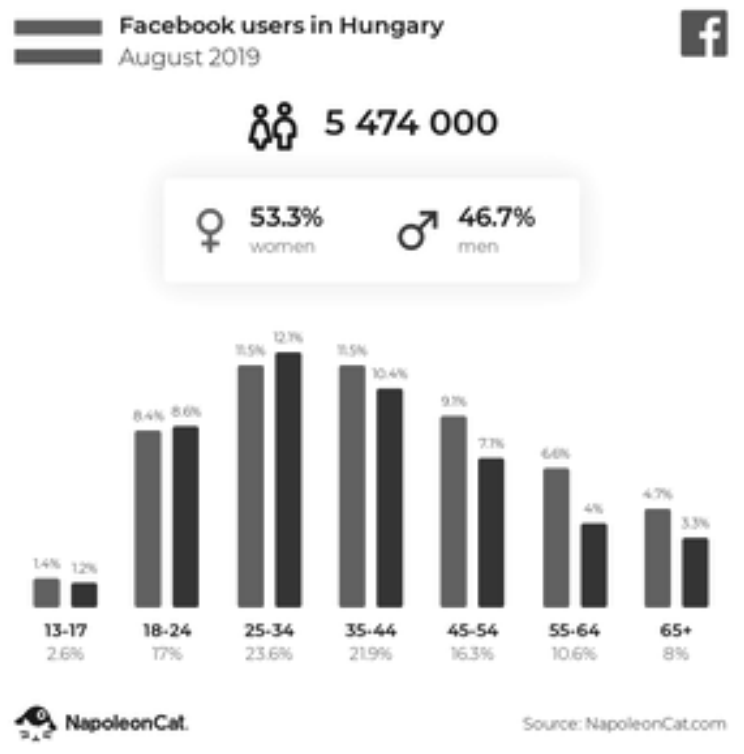

Рис. 1. Дані про користувачів Facebook у 2019 році в Угорщині Джерело: Mutatjuk, hogy kinek milyen közösségi média platformot érdemes használnia marketingjéhez 2020-ban https://www.digitalhungary.hu/kozossegimedia/Mutatjuk-hogy-kinek-milyen-kozossegi-media-platformot-erdemeshasznalnia-marketingjehez-2020-ban/

Більше половини угорського населення $(56,8 \%)$ користується Facebook, мова йде про 5474000 людей. 3 них 53,3\% - жінки, 46,7\% - чоловіки. Тенденція спостерігається між віковими групами та розподілом за статтю. До 45 років різниця між користувачами чоловічої і жіночої статі незначна, проте вище 45 років число починає рости на користь жінок. У віковій групі 55-64 років ця різниця становить вже 140000 користувачів. 
Facebook забезпечує статус найкращої платформи соціальних медіа з погляду бізнесу. Оголошення у Facebook, за допомогою яких можна точно знайти свою цільову аудиторію або іiї інтегрувати в електронну комерцію, що дозволяє дуже легко продавати продукти з допомогою Facebook.

Messenger також дуже популярний в Угорщині, з точки зору маркетингу соціальних медіа. На цій платформі охоплюються користувачі, які відсутні у маркетингу на Facebook.

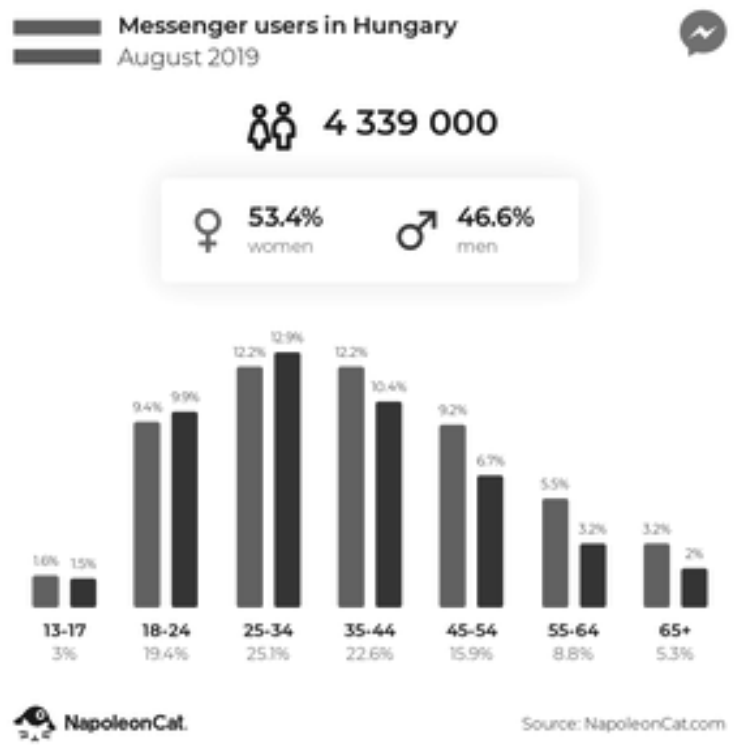

Рис. 2. Дані про користувачів Messenger у 2019 році в Угорщині Джерело: Mutatjuk, hogy kinek milyen közösségi média platformot érdemes használnia marketingjéhez 2020-ban https://www.digitalhungary.hu/kozossegimedia/Mutatjuk-hogy-kinek-milyen-kozossegi-media-platformot-erdemeshasznalnia-marketingjehez-2020-ban/

В Угорщині в серпні 2019 року Messenger користувалося 4399000 осіб. Це менша кількість, ніж у Facebook, але це практично половина населення, тобто 45\%. Дані, наведені нижче, говорять про те, що жінки більш комунікативні. Так, на цій платформі частка жінок становить 53,4\% від усіх користувачів. Найбільше їх у віковій групі 25-34 років, а саме 1090000 користувачів. Найбільша різниця між чоловіками та 
жінками є також у віковій групі 45-54 роки, де їх на 110 тис. більше.

Instagram. Нині багато інтернет-маркетологів називають Instagram другим Facebook. Усе більше і більше старших людей користуються цією платформою, але все ж таки менше, ніж Facebook. Згідно з останніми дослідженнями, проведеними науковцями масмедіа, з'ясувалося, що ця вікова група в Угорщині висловлює все більшу прихильність саме до Instagram.

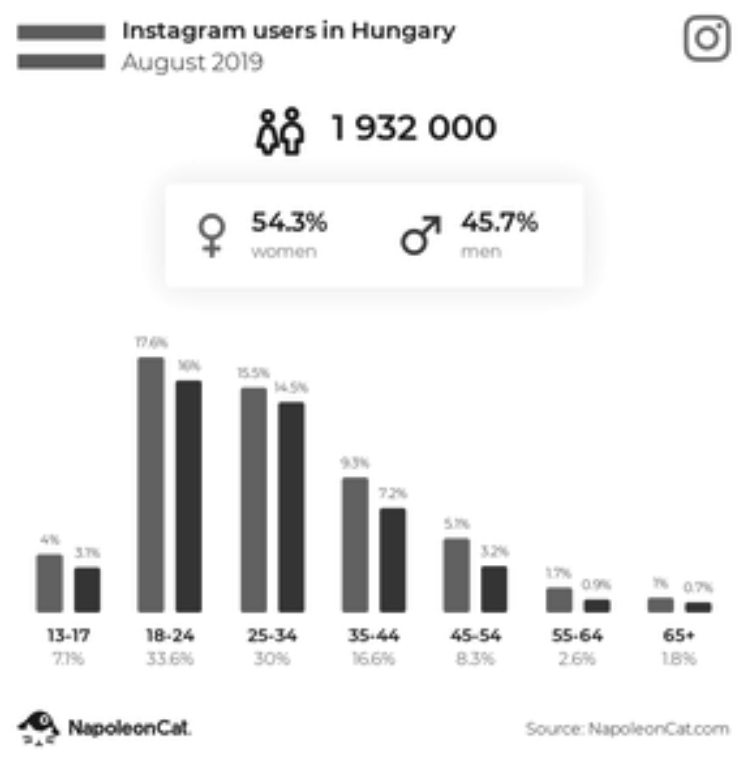

Рис. 3. Дані про користувачів Instagram у 2019 році в Угорщині Джерело: Mutatjuk, hogy kinek milyen közösségi média platformot érdemes használnia marketingjéhez 2020-ban https://www.digitalhungary.hu/kozossegimedia/Mutatjuk-hogy-kinek-milyen-kozossegi-media-platformot-erdemeshasznalnia-marketingjehez-2020-ban/

В Угорщині 1932000 користувачів Instagram, що становить 20,1\% населення: 3 них 54,3\% - жінки та 45,7\% - чоловіки. Розподіл за віком стає тим більш зрозумілим, що Instagram не орієнтується на старшу вікову групу, тому що рівень рентабельності реклами (ROI) серед цих користувачів досить низький. У той же час ця платформа дає дуже гарні показники у молоді (до 30 років). Тут можливо охопити 650000 користувачів у ві- 
ковому сегменті 18-24 років. На Facebook у цій віковій групі $€$ менше 930000 користувачів. У людей у віці 55-64 років значна кількісна перевага жінок над чоловіками. Порівняно з 2017 роком кількість користувачів Instagram зросла на 732 000, це одна iз перспективних, зростаючих мереж в Угорщині.

Linkedin зростаюча, перспективна медіаплатформа. Вона обіцяє у найближчий час охопити більшу кількість бізнескористувачів соціальними медіа.
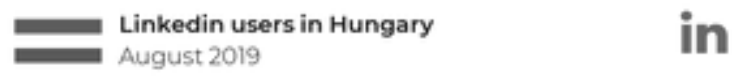

\section{ถిจి 1018000}

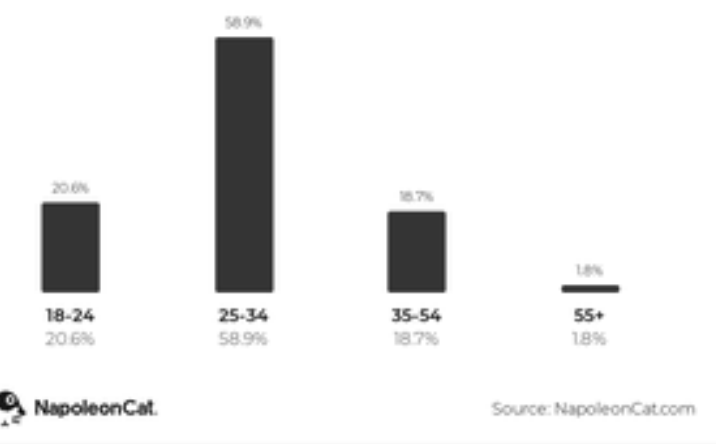

Рис. 4. Дані про користувачів Linkedin у 2019 році в Угорщині Джерело: Mutatjuk, hogy kinek milyen közösségi média platformot érdemes használnia marketingjéhez 2020-ban https:/www.digitalhungary.hu/kozossegimedia/Mutatjuk-hogy-kinek-milyen-kozossegi-media-platformot-erdemeshasznalnia-marketingjehez-2020-ban/

В Угорщині Linkedin має 1,018 000 користувачів. Це 10,6\% населення країни, тому це досить пристойна кількість. Найбільша кількість користувачів 600 000, тут складає вікова група 25-34 роки, найменша серед тих, кому за 55 років.

Pinterest стрімко ввірвався в Угорщину і досить швидко завоював значну аудиторію користувачів. Він уже на шостому місці у топ-списку серед угорських платформ соціальних ме- 
діа. Згідно з даними Pinterest за 2018 рік, платформа охопила 1074000 користувачів в Угорщині. Непоганим їх рішенням був орієнтир на жінок віком 15-35 років, саме у категорії моди, здоров'я та аксесуарів. Порівняно 3 минулим роком, це призвело до другого за величиною збільшення клієнтів серед соціальних мереж.

Twitter. Кількість угорських користувачів у 2018 році становила 398 000, і він посів сьоме місце у списку соціальних мереж країни. На той час, як бачимо, платформа мала мало користувачів, але зараз їх активність зростає. Порівняно з минулим роком кількість користувачів зросла на $0,3 \%$.

Соціальні медіа зростають в Угорщині за експонентою 3 2004 року. Доступність серед людей явно зростає, оскільки постійне розповсюдження смартфонів уже стало невпинним процесом. Кожна платформа соціальних медіа має власні додатки для мобільних пристроїв, або принаймні їх вебсайти оптимізовані. Маркетинг соціальних медіа, як маркетингова стратегія, який ще декілька років по тому був у зародковому стані, сьогодні вже заволодів свідомістю професіоналів. Застосовуючи його, можна цілеспрямовано охопити мільйони користувачів в Угорщині. Як панацея від інтернет-маркетингу, проведення та аналіз відповідних досліджень ринку разом - це дуже вигідне рішення для конкуренції всередині країни.

Фейсбук був основою системи 3 моменту поширення соціальних медіа. Це важливий елемент планування угорської медійної стратегії та побудови бренду Угорщини в світі[20].

Після того як ми розглянули положення світових інтернетпорталів в Угорщині, перейдемо до ситуації, яка склалася на ринку угорських Інтернет-новинних порталів.

На першому місці популярності серед місцевих сервісів в Угорщині - Index, Інтернет-портал новин, який уже давно $є$ одним з найбільш відвідуваних. У середньому за місяць число відвідувачів сайту Index досягає 35 мільйонів. Його також читають жителі Великобританії (3,7\%), Німеччини (2,6\%), США та Румунії (1,7\%). Портал використовує соціальну мережу Facebook, Google, пошукову службу, відео YouTube та локальну версію міжнародного класифайду OLX. 
Він з'явився в 1999 році та зайняв особливе місце в системі угорських медіа. Згідно з дослідженнями Юдіт Барта, Index увів нову функціональну модель у систему ЗМІ Угорщини. Він почав демократизацію публічної сфери в державі, надавши суспільству більш автономну комунікаційну систему. Більш того, на самому початку угорська аудиторія ідентифікувала Інтернет $з$ цим онлайн-порталом. Попередником порталу Index, що відіграє в сучасній Угорщині роль одного з головних джерел інформації і громадянської консолідації, з'явився ще в 1995 р. Internetto.hu, заснований Андрашем Нipo. Саме Internetto.hu приписують роль зміни способу Інтернету в Угорщині від «демонічного простору для педофілів і виробників бомб» до рівня мейнстримного медіа. Дуже швидко Internetto.hu стала читати еліта, яка формує думки, топ-100 000, як висловився один із засновників сайту. Але в 1999 p. pecypc Internetto.hu, як комерційно неприбутковий, був закритий. У цьому ж році Андраш Нiро, Петр Уй і Габор Герен створюють на базі Internetto.hu Index, який було вирішено зробити комерційно успішним. Незважаючи на нову установку, саме портал Index сьогодні багато в чому формує і підтримує демократичну публічну сферу, а в своїх інтерв'ю багато лівих та правих журналістів зізнаються, що читають Index регулярно.

Головну цінність, яку надав аудиторії Index, за словами Петера Уя, складають неупереджені новини. У деякому роді можна говорити про політичну незаангажованість цього медіа. «Індекс», що зародився в 1999 р. в онлайн-середовищі, навмисне порвав 3 поділом медіа на правих і лівих. Що стосується політичних прихильностей, головний редактор порталу так описує політику редакції: «Угорські медіа в занепаді, як і всі в цій країні. I вони шукають зовнішні причини цього, такі, як економічна або політична цензура. Я не думаю, що цензура така могутня. Index був дивним експериментом, ми почали з малого і не були у фокусі уваги. В цьому була основна привабливість онлайнмедіа. Ми не хотіли вплутуватися в траншейну війну, яка тоді йшла». Петер Уй стверджує, що політично й економічно його медіаджерело більш незалежне, ніж його конкуренти, хоча існує і незначний компроміс. 
У 2002 р., коли Інтернет-світ переживав період рецесії, Index був куплений компанією «Уолліс» (Wallis), що спеціалізується на купівлі підприємств-банкрутів, щоб допомогти їм відновитися, і продає їх після, компанія вже відрізнялася високою прибутковістю. У редакції Index у той момент не було вибору, i їй довелося прийняти допомогу. В 2007 р. 100\% акцій порталу викупив інвестор Криштоф Нобіліш, флагманською компанією якого є «Центрально-Свропейська видавнича та медіакомпанія» (Kozep Europai Media es Kiado Szolgdltato Zrt.).

32007 p. Index щодня переглядає понад 400 тис. читачів. Один з блогерів, який працював у секції «Технології» в 2007 p., вважає, що «у випадку з масовим ЗМІ роль компромісів, на які потрібно йти, досить велика». Index являє собою суміш 3 розслідувальної журналістики і бульварних новин. Це спеціальна ніша на угорському медіаринку. Однією з найважливіших особливостей Index також є те, що ще в 1995 році керівниками Internetto.hu було вирішено робити ресурс спільно з читачами. Перші автори порталу вийшли з читацької середовища, а деякі до цих пір працюють у штаті редакції. 3 цього, очевидно, випливає, що автори писали про те, що було цікаво їм самим. Традиція ця, як нам здається, до цих пір збережена. Хочеться також зазначити, що Internetto.hu, а потім і Index безумовно відповідальні за появу в Угорщині громадянської журналістики: вони починали з любителів-ентузіастів; аналізували події, які були цікаві їм, показуючи таким чином, що суб'єктивність - невід'ємна риса ньюсмейкер, на противагу традиційній об'єктивній розповіді репортерів; читачі й журналісти часто мінялися місцями - редакторсько-репортерська робота і чат 3 форумом часто перетиналися; нарешті, три молодих члени редакції взагалі не отримували заробітної плати, для них це було хобі.

Оскільки спочатку Index узяв на себе подвійну роль, спостерігаючи за діями офіційної влади, адаптуючи розслідувальну журналістику і охоплюючи таблоїдні новини в один і той же час, то одним з аспектів таблоїдизації Index став стиль матеріалів. У редакції вирішили, що таким чином можна буде залучити більший прошарок аудиторії. I в результаті сформувався свій 
особливий стиль, який потім з інтернет-порталу частково перейшов і в багато друкованих видань [21].

Наприкінці березня 2020 року Міклош Васілі придбав 50-відсоткову частку групи Indamedia Group, до складу якої входить також компанія Indamedia Sales Kft. (раніше CEMP Sales House Kft.), яка ексклюзивно розміщує рекламні місця Index.hu. Baciлі багато років працював у Echo TV та TV2.

21 червня 2020 року індикатор свободи, який вказує на незалежність редакції газети, змінився для Index 3 «незалежного» на «в небезпеці». У статті в 444 hu.на подібну тему повідомляється про ініціативу, яку висловив Габор Гереній - співзасновник Index, про те, щоб усю редакційну та публіцистичну роботу порталу передати в незалежні від редакції руки.

22 липня 2020 року Ласло Бодолай, голова правління Index. hu Zrt., ініціював звільнення Сабольча Дулла, у той же час він запросив Пала Сомбаті на посаду генерального директора, а Андраш Станкачочі приєднався до Ради директорів Index. Peдакція порталу одноголосно назвала звільнення Дулла неприпустимим, оцінивши це як втручання в роботу редакції. Журналісти попросила повернути Дулла, але Бодолай відмовився це зробити, після чого багато з них подали заяви на звільнення, зокрема Аттіла Тот-Сенеші, головний редактор, та Вероніка Мунк і Янош Хаас, заступники головного редактора, та понад вісімдесят працівників.

У зв'язку з подіями 24 липня відбувся протест з ініціативи опозиційної ліберальної партії Momentum та націоналістичної партії Jobbik на захист вільної преси, де тисячі протестувальників пройшли від редакції медіа вздовж Дунаю до офіційної резиденції прем'єр-міністра Угорщини Віктора Орбана у Замку Буда [22].

Журналіст Тамаш Фабіян детально написав причини звільнення: «Ми не повинні були погодитися з власниками Index, близькими до Фідес, які дали зрозуміти, що ми повинні писати повідомлення в межах, які вони визначають. Вони також дали зрозуміти, що ці рамки будуть змінюватися відповідно до політичних міркувань, постійно звужуючись. Якби ми пішли цим шляхом, Index перестав би існувати як незалежний портал. Ми 
не дозволили їм це зробити, принижувати все, що сотні людей робили 3 жертовністю за останні 21 рік» [23].

Ці події отримали розголос і за кордоном, тому Фідес навіть надіслав листа членам Свропейської народної партії з поясненням ситуації, яка склалася навколо Index. У ньому вони написали, що бізнес-рішення приватної компанії не мають нічого спільного з урядом. У той же час, угорські опозиційні члени Свропарламенту заявляють, що уряд намагається змусити замовчати опозиційні засоби масової інформації завдяки передачі їх у власність олігархів, близьких до Орбана.

NCore - один із найбільших угорських торрент-сайтів, доступний угорською та англійською мовами. 17 січня 2015 року було зареєстровано понад 670 тисяч зареєстрованих користувачів. Реєстрація здійснюється лише за запрошенням.

NCore був запущений 16 січня 2005 року як Endless. Оскільки Endless мав проблеми з сервером, вони прагнули створити власний сервер, замість ТВsource (wd), який використовувався в той час. Skyline запропонувала сервер для Endless, який вони прийняли, тому Endless i Skyline злилися й стали існувати як Endless-Skyline. Торрент-сайт працює під назвою nCore 326 червня 2007 року [24].

У квітні 2012 року відбулася зміна форми власності. Після цього за короткий час можна було зайти на сайт за допомогою реєстрації sms. У травні 2014 року nCore створила свою офіційну сторінку у Facebook. До цього на сайті також була сторінка Twitter. У серпні 2015 року невідомі злочинці скористалися вадою програмного забезпечення nCore, щоб спрямувати декількох користувачів Інтернету на підроблений вебсайт, де їм потрібно було ввести новий пароль.

Середнє число відвідувачів сайту в місяць - більше 22 мільйонів, в Угорщині виходить 80\% трафіку, 5,6\% - у Великобританії, наступні Румунія, Словаччина та Німеччина. У глобальному рейтингу відвідуваності сайт займає 932 місце, в локальному - шосте.

3. Freemail (вимовляється: frimel; назва, утворена від англійських слів означає «вільний лист») - назва популярної безкоштовної угорської системи електронної пошти. Кількість ко- 
ристувачів на вебсайті в лютому 2007 року становила понад 3 мільйони, а 3,78 мільйона активних поштових скриньок та 12 мільйонів електронних листів щодня доставлялося в січні 2012 року [2]. У 2014 році на сайті було 3,74 мільйона активних поштових скриньок та 550000 відвідувачів щодня.

Freemail був розроблений культурним і комунікаційним центром С3 Фонду Сороса в 1996 році. Він був запущений 2 жовтня 1997 року. Створення Freemail було частиною мети Фонду Cороса щодо просування та поширення Інтернету в Угорщині. Тим часом, розвиток сектору ринкових послуг й інфраструктури зробили алогічною участь неурядової організації в цьому проєкті, тому Freemail 30 червня 1999 року приєднався до порталу Оріго. У 2003 році Magyar Telekom Plc. узяв на себе функціонування сайту та включив його до портфоліо T-Online, а розробку його контенту здійснює фонд, який з тих пір змінив назву на С3.

Найпростіший спосіб отримати доступ до облікових записів безкоштовної пошти - це стандартний веббраузер або програма електронної пошти. Також Freemail має автономний комутований доступ, який підтримується Т-Ноme. Особливості включають 10 Гб пам'яті (з 4 червня 2010 р., раніше був 1 Гб з 2 березня 2007 р.), налаштовану фільтрацію пошти, фільтрування спаму та вірусів, доступ до WAP, чат й адресну книгу. Файл, прикріплений до пошти, не може перевищувати 5 Мб, а всі вкладені до нього повідомлення не можуть перевищувати 10 Мб. У гігантському листі файл до 1 Гб можна перенести, але не як вкладення, а шляхом завантаження у зону зберігання безкоштовної пошти, яка доступна лише у визначений проміжок часу від одержувача. Послуга також доступна через спрощений інтерфейс і розрахована на незрячих та людей з поганим зором.

Щомісяця ресурс отримує в середньому 19 мільйонів відвідувачів. У березні 2015 року компанія продала загалом 19,8 мільйона. Середня тривалість одного візиту -4 хвилини. Freemail в Угорщині має 99\% трафіку, 1\% припадає на жителів Німеччини, Австрії, Великобританії та Румунії разом узятих.

У рейтингу відвідувань сервіс займає сьоме місце в Угорщині після nCore, в глобальному - 1227 місце [25]. 
Origo - один з найбільш відвідуваних новинних порталів Угорщини. Він став провладним у 2014 році після того, як його власниками стали бізнесмени, близькі до третього уряду Орбана. На підтримку урядової антиміграційної кампанії він зображує мігрантів, які нещодавно перебралися жити до Західної Європи, в негативному дусі, інколи навіть переробляючи пов'язані з ними новини із закордонних ЗМІ на негативний лад.

Підготовка до створення Origo розпочалася у травні 1997 року. Колишні журналісти часопису Magyar Narancs: Надоі Петер, Похлі Ференц, Шімо Дьордь та Веєр Балаж отримали замовлення від Matáv - угорської телекомунікаційної компанії, щоб скористатися можливостями Інтернету для створення Інтернет-порталу. В 1998 році було створено Origo.

Спочатку автори проєкту хотіли створити сторінку, яка поєднала б відредагований контент з іншими службами. Ось чому вони також придбали поштовий сайт Freemail у 1999 році. Того ж року було також розроблено базу програмного забезпечення сайту. Іноземні (переважно американські) Інтернет-портали, такі як Yahoo, AOL або Altavista, були використані в якості прикладів при створенні сайту.

3 самого початку Origo інформувало читачів про: вітчизняні, закордонні, спортивні, технологічні, економічні, наукові новини. Був створений спеціальний розділ для жінок. База програмного забезпечення була запущена в 1999 році й постійно розширювалася: кіноклуб, еротика, музика, автомобілі, телебачення, охорона здоров'я, робота, нерухомість, подорожі й т. п.

Головним редактором порталу до 2000 року був Петер Надорі, якого потім замінив Балаш Ваєр, редактор, що раніше відповідав за розвиток сайту.

Цього року портал став найбільш відвідуваним сайтом в Угорщині, а також отримав новий, більш відповідний порталу логотип. Також була запущена тематика щодо автомобілів. У 2001 році події 11 вересня в США значно збільшили трафік сайту.

У 2006 році було придбано iWiW, а також створено функцію блогу, обміну відео. У січні 2007 року сайт отримав абсолютно новий вигляд і з Google було підписано контракт, тому з тих пір використовується нова пошукова система. Також була до- 
дана одна-дві нові функції, а саме: опубліковані статті можна оцінити, а коментарі до них можна додати в інтерфейсі blogter. hu після статей.

Спочатку редакція налічувала 9 осіб. Сьогодні до іï складу входять 95 співробітників, з яких близько 40\% працюють усередині компанії, 30\% зовні, а решта 30\% - «інформаційними постачальниками» інформаційних агентств або корпорацій.

Портал отримав новий вигляд у вересні 2009 року. В новій версії титульна сторінка вказує на те, що сайт має більше внутрішнього контенту, ніж раніше.

31 лютого 2010 року Міклош Василі, який раніше працював y Index, став генеральним директором компанії Origo. Його завдання полягало в тому, щоб зробити портал та пов'язані з ним частини (наприклад, iWiW) прибутковими й збільшити дохід від реклами. У 2010-11 роках декілька досвідчених журналістів поповнили штат порталу.

У кінці серпня 2011 року дизайн знову було поновлено. Крім вимоги друкувати статті із зображеннями стандартних розмірів у кількох кольорах, рекомендація щодо обов'язкової статті у верхній частині обкладинки була обов'язковою.

29 вересня 2011 року несподівано було оголошено, що головний редактор Балаш Ваєр та Петер Надорі з 2 листопада йдуть у відставку, а їх на цій посаді замінить Альберт Газда.

Герго Шалінг був головним редактором Origo 3 листопада 2013 року, але після парламентських виборів 2014 року політика все активніше втягувалася в діяльність Origo, і Шалінг вирішив піти з порталу влітку 2014 року. Вилучення Шалінга було пов'язане зі скандалом, який виник після надрукованої критичної статті про діяльність Яноша Лазара - лідера парламентської групи Фідес, а потім міністра канцелярії прем'єрміністра Віктора Орбана. 3 відставкою Шалінга значна частина журналістів порталу також подала у відставку. 3 червня 2014 року головним редактором став Акош Плмаі, який протягом попередніх чотирьох років керував телевізійним та веб-бізнесом відео Origo Zrt.

У 2015 році Magyar Telekom оголосив про продаж «Оріго» після того, як німецька материнська компанія Deutsche Telekom 
зменшила свої інтереси до ЗМІ всюди в Європі. Кілька медіагруп висловили намір придбати портал, але наприкінці року компанія врешті-решт приєдналася до «New Wave Mediá», яку очолює Іштван Сараз та якій також належить VS.hu.

На початку 2017 року кілька колишніх співробітників також покинули Origo, деяких звільнили, а деякі подали у відставку. Повідомляється, що це було пов'язано зі змінами у редакційній політиці порталу.

У квітні 2017 року Dry Circular оголосив, що Origo Media змінила свою назву на New Wave Media Group Zrt. У той же час, 13 квітня хакерська група Anonymousmus опублікувала тисячі коментарів під усіма статтями на порталі, сказавши: «Ми не підемо звідси, поки Origo не вирветься з прямої кишки правлячої партії і не зачинить свої двері пропагандистським сайтам Путіна». Тоді Origo з міркувань безпеки виключив коментування, яке $з$ тих пір не було відновлено.

12 жовтня 2017 року весь колектив кіновідділу Origo оголосив про свою відставку, тому що Балінт Бордак опублікував критику двох фільмів про мігрантів, у підтримку антимігрантської кампанії уряду Орбана. Колишні співробітники порталу зазначали, що вони повністю не підтримують таку редакційну політику.

331 грудня 2017 року New Wave Media Group Zrt., яка керує Origo, об'єдналася зі своєю новою материнською компанією New Wave Media Kommunikációs és Szolgáltató Kft., заснованою у 2014 році разом з New Wave Production Kft., яка управляє VS.hu.. Дві компанії-попередниці припинили своє існування як окремі утворення. Після закінчення транзакції статутний капітал юридичного правонаступника - об'єднана компанія - збільшився з попередніх 3 млн форинтів до 340 млн форинтів.

1 березня 2018 року на kolozsvaros.com Тамаш Рубер заявив, що Origo бере участь у розпалюванні пропаганди проти мігрантів шляхом свідомого поширення брехні. Новини про мігрантів отримали ще більшу популярність на сайті за тижні, що залишаються до парламентських виборів.

Після виборів портал разом із кількома провладними 3МІ змушені були внести низку виправлень після того, як було 
3’ясовано, що він допускав грубі помилки у своїх статтях, що стосуються опозиційних партій та політиків. Origo у 2018 році найчастіше вибачалося за допущені помилки.

Навесні 2019 року після того, як New Wave Media Group, якій належить Origo, також виграла гроші на тендері DNI від Google, американська компанія відмовилася від підтримки урядового порталу насамперед через те, що портал опублікував статті, які містять неправдиву інформацію, в основному пов'язану з міграцією та опозиційними політичними партіями і їх лідерами [26].

У березні 2020 року стало повністю зрозуміло, що редакція вебсайту не $\epsilon$ незалежною, портал почасти створювався, контролювався та керувався не правдивим відображенням інформаціiі, а вказівками оточення Орбана або його особистими настановами.

На п’ятому місці серед угорських Інтернет-новинних порталів - блогоплатформа Blog. У ній жителі Угорщини діляться фотографіями, відео, актуальними новинами, публікують власні матеріали. Усі записи діляться на категорії: культура, технології, їжа, лайфстайл, спорт і так далі. Середня відвідуваність ресурсу - 20 мільйонів візитів у місяць. Середня тривалість одного візиту - трохи більше двох хвилин. 85\% трафіку сервіс отримує з Угорщини. За відвідуваністю, в країні платформа займає десяте місце. Її випереджає тільки онлайн-енциклопедія Wikipedia [27].

На шостому місці Hasznaltauto - платформа для пошуку автомобілів та іншого транспорту. На сайті можна знайти не тільки легкові автомобілі, а й автобуси, мотоцикли, фургони, причепи для вантажного транспорту, катери та яхти. Основна маса відвідувачів сервісу - жителі Угорщини, на них припадає до 92\% усього трафіку на сайт. Усього в місяць Haznaltauto отримує трохи більше 5 мільйонів відвідувань. Середня тривалість одного візиту при цьому становить 11 хвилин [28].

На сьомому місці Jofogas, ще один класифайд. Тут можна знайти оголошення про пошук роботи, про продаж дитячих речей, автомобілів і нерухомості. Оголошення можна відсортувати за регіонами і за категоріями. У сервісу є власні мобільні 
додатки для Android та iOS. В Угорщині, за відвідуваністю, сайт займає 13 місце, поступаючись міжнародній пошуковій системі Yahoo. У місяць сайт отримує 8 мільйонів відвідувань, а в глобальному рейтингу відвідуваності займає 2518 місце. Лише $39 \%$ переходів на сайт користувачі здійснюють за прямим посиланням. 25\% припадає на пошукові запити, причому в число найпопулярніших запитів потрапили інші класифайди - OLX i Haznaltauto [29].

На восьмому місці серед місцевих сайтів - новинний агрегатop HVG. Серед найпопулярніших тем дня - вплив угорського уряду на діяльність транснаціональних корпорацій у країні й обговорення нового податкового плану, сформованого владою. У березні показник числа відвідувань агрегатора досяг максимуму за останні шість місяців - більше 16 мільйонів. Середня тривалість одного візиту на сайт становить 19 хвилин. 84\% відвідувачів HVG - жителі Угорщини. Значну частку трафіку (40\%) ресурс отримує з соціальних мереж (99\% - з Facebook, на другому місці Twitter) [30].

Дев'яте місце займає Sports747 - спортивний новинний сервіс, де можна дізнатися результати змагань, останні новини спорту, подивитися прямі трансляції матчів. Перший у рейтингу сервіс з інтерфейсом англійською мовою. 3 Угорщини цей угорський сервіс отримує лише $11 \%$ усього трафіку. 7\% - 3 Японії, по 6\% - з Бразилії та Польщі, 5\% - з Індії. Сервіс займає 345 місце в рейтингу відвідуваності по всьому світу.

Сайт був запущений навесні 2013 року, але до лютого 2015 року його відвідуваність трималася на рівні від 50 тисяч до 1 мільйона візитів у місяць. У лютому цей показник становив 16 мільйонів, а в березні - 110 мільйонів. 80\% переходів сайт отримує $з$ рекламних оголошень на інших сервісах. Безпосередньо на Sports747 заходять лише 1,5\% відвідувачів.

Десятим серед сайтів $є$ Hir24, ще один новинний агрегатор. Публікує новини політики, університетів Угорщини, скандали, фінансові звіти. Відвідуваність у березні 2015 року досягла 16,2 мільйона візитів.

Підбиваючи підсумок сучасного стану електронних засобів масової інформації в Угорщині, потрібно зазначити, що країна у 
цьому сегменті масмедіа досягла за останні роки значних успіхів. Свій подальший розвиток отримали радіо та телебачення. Потужно ввірвався у медіапростір Інтернет. Усі провідні світові Інтернет-платформи соціальних медіа присутні в Угорщині. У країні також створено мережу угорських Інтернет-новинних порталів. У той же час, і в онлайн-середовищі зберігається тенденція активного втручання уряду Орбана та його оточення в контроль і управління електронними ЗМІ. Практично всі головні угорські Інтернет-новинні портали контролюються владою, а ті, що знаходяться в опозиції, мають незначний ресурс і невелику аудиторію. Ця ситуація викликає гостру критику як усередині країни, так і за її кордонами. Однак Орбан робить вигляд, що це його не обходить і що це внутрішні справи країни. Зрозуміло тільки одне, доки Фідес буде при владі, доти його політика щодо масмедіа буде незмінною. Орбан чудово розуміє: у кого в руках засоби масової інформації - у того в руках і влада, а владу у найближчі 10 років він нікому віддавати не хоче.

\section{Література}

1. А.И. АКОПОВ СРЕДСТВА МАССОВОЙ ИНФОРМАЦИИ ВО ВРЕМЕНИ И ПРОСТРАНСТВЕ: ТЕНДЕНЦИИ РАЗВИТИЯ И ТРАНСФОРМАЦИЙ. file://C:/Users/dtkac/Downloads/ Fkzh_2013_39_3\%20(1).pdf

2. Frank Arute, Kunal Arya, Ryan Babbush, Dave Bacon, Joseph C. Bardin. Quantum supremacy using a programmable superconducting processor (англ.) // Nature. - 2019. - October (iss. 7779, no. 574). P. 505-510.

3. The New Rules of Marketing and PR: How to Use Social Media, Blogs, News Releases, Online Video, \& Viral Marketing to Reach Buyers Directly. - М.: «Альпина Паблишер», 2011. - 354. Miloš, Todorović. From Diderot's Encyclopedia to Wales's Wikipedia: a brief history of collecting and sharing knowledge (англ.) // KSIO : journal. 2018. - No. 1. - P. 88-102.

5. История MySpace: почему Крис Де Вольф и Том Андерсон проиграли конкуренцию с Facebook https://vc.ru/social/13758myspace-story

6. The Google Story: Inside the Hottest Business, Media, and 
Technology Success of Our Time / Пер. с англ. О. В. Мацака; под ред. Е. М. Бузниковой. - М.: Эксмо, 2007. - 368 с.

7. Вікіпедія https://uk.wikipedia.org/wiki/ Вікіпедія: Про\# Посилання

8. The new, new Myspace leaves beta - launches a revised design, new features, \& a mobile app. VentureBeat.

9. Чекмишев О.В., Ярошенко Л.А. Основи якісного блогерства // Асоціація «Спільний простір», Комітет «Рівність можливостей»/ Навчальний посібник . - К.: 2014, ФОП А.М. Рудницька, с. 48.

10. Дзьобань О.П. Філософія ін формаційного права: світоглядні й загальнотеоретичні засади: Монографія. - Харків: Майдан, 2013. $-360 \mathrm{c}$.

11. A Duna Médiaszolgáltató Zártkörüen Müködő Nonprofit Részvénytársaság. https://www.wikiwand.com/hu/Duna_M hu/Duna_ Médiaszolgáltató

12. Hungarian radio stations by listeners (2013), data from TNSHoffmann-Mediameter company, Magyar Nemzet (Hungarian)

13. Vételi lehetöségek - Rádió. (Hozzáférés: 2020. január 13.)

14. Agárdi Péter: A Magyar Rádió utolsó 15 éve - Médiakutató, 2004. ösz

15. MTVA. http://mtva.hu/

16. Az ORTT ügyrendje. [2010. március 31-i dátummal az eredetiből archiválva]. (Hozzáférés: 2010. szeptember 6.)

17. 2015. július 1. - Duna Médiaszolgáltató Zártkörüen Müködő Nonprofit Részvénytársaság elnevezéssel egyesül a négy közszolgálati médiaszolgáltató

18. Венгерское телевидение. https://ru.wikipedia.org/wiki/5/ Венгерское_телевидение

19. A magyarok 83 százaléka használ közösségi oldalakat https:// www.hwsw.hu/hirek/57550/eurostat-europai-unio-kozossegi-mediahasznalati-adatok.html

20. Mutatjuk, hogy kinek milyen közösségi média platformot érdemes használnia marketingjéhez 2020-ban https://www. digitalhungary.hu/kozossegi-media/Mutatjuk-hogy-kinek-milyenkozossegi-media-platformot-erdemes-hasznalnia-marketingjehez2020-ban/

21. Gerényi Gábor: Az Index.hu sztori (tartalomjegyzék). gg.blog, 2013. (Hozzáférés: 2020. június 25.)

22. У Будапешті тисячі людей протестували проти втручан- 
ня Орбана в роботу 3MI https://www.eurointegration.com.ua/news /2020/07/25/7112523/

23. Az Index újságírója részletesen megírta, miért mondtak fel 444. hu, 2020. július 25. https://444.hu/2020/07/25/az-index-ujsagirojareszletesen-megirta-miert-mondtak-fel

24. Az nCore is áldozatul esett a razziának (HTML). Index, 2010. június 19. (Hozzáférés: 2017. január 17.)

25. Tizenöt éve levelezhetünk a [freemail-en]. Origo, 2012. október 2. [2014. október 22-i dátummal az eredetiből archiválva]. (Hozzáférés: 2014. október 22.)

26. origo.hu Competitive Analysis, Marketing Mix and Traffic Alexa. Alexa. (Hozzáférés: 2020. július 29.)

27. Blogírás (magyar nyelven). ATP. (Hozzáférés: 2019. június 14.)

28. Hasznaltauto. http://mediapedia.hu/hasznaltautohu

29. Így ért véget az apróhirdetők nagy háborúja. Index, 2015. február 19. (Hozzáférés: 2016. május 21.)

30. Kókay-Buzinkay-Murányi: A magyar sajtó története, Budapest, Sajtóház Kiadó, 2020. 


\section{0. Масмедіа Угорщини про проблеми в українсько-угорських відносинах, пов'язані із Законом про освіту}

Починаючи з 1990 року, всі уряди Угорщини у зовнішньополітичній діяльності визначали такі пріоритети: інтеграція до європейських та євроатлантичних структур, розвиток добрих відносин із сусідніми державами і захист прав національних меншин, що проживають за кордоном [1, с.376].

Останній напрям зовнішньої політики, пов'язаний з так званим «посттріанонським синдромом», який уже протягом сторіччя присутній у суспільному житті Угорщини. Тріанонський мирний договір був підписаний 4 червня 1920 р. у Великому Тріанонському палаці Версаля між Угорщиною, з одного боку, i союзними державами: США, Британською імперією, Францією, Італією, Японією, Бельгією, Грецією, Китаєм, Кубою, Нікарагуа, Панамою, Польщею, Португалією, Румунією, Югославією, Сіамом і Чехословаччиною - 3 іншого. Правова безглуздість - 3 боку переможців серед підписантів Тріанона виявилися держави, які не існували на момент підписання перемир'я у Першій світовій війні: Польща, Королівство сербів, хорватів і словенців (майбутня Югославія) та Чехословаччина. Для міжвоєнного світу в Європі назви палаців французьких королів - Тріанон і Версаль - стали символами несправедливого світу, які вимагали справедливого військового реваншу.

Договір був сформульований за зразком Сен-Жерменського мирного договору 1919 р. із Австрією, причому деякі статті й навіть частини їх збігалися майже дослівно. Тріанонський мирний договір складався 314 частин (усього 364 статті), протоколу та декларації. Частина II (ст. 27-35) містила опис кордонів 
Угорщини з Австрією, Королівством сербів, хорватів і словенців, Румунією та Чехословаччиною. До Румунії відійшли Трансільванія і східна частина Банату; до Югославії - Хорватія, Бачка і західна частина Банату; до Чехословаччини - Словаччина i Закарпатська Україна. Провінція Бургенланд була передана Австрії. Угорщина відмовлялася на користь союзників від будьяких прав на порт Фіуме [2].

Тріанонський мирний договір був ратифікований регентом М. Хорті 15 листопада 1920 р. і вступив у силу після його ратифікації більшістю підписантів 26 липня 1921 р. Договором передбачалися умови, за якими Угорщина втратила $2 / 3$ своєї території з населенням до 3 млн своїх громадян, вихід до моря й флоту, $88 \%$ лісових ресурсів, $83 \%$ виробництва чавуну і $67 \%$ банківсько-кредитної системи й відповідної кількості культурних ресурсів. Ї̈̈ територіальні втрати були найбільшими у порівнянні з іншими переможеними країнами Четверного союзу. Ця угода була певною мірою помстою угорцям за наслідування прикладу російських більшовиків і створення Угорської радянської республіки.

4 червня 2020 року Угорщина відзначила століття Тріанона черговим Днем національної єдності як вельми знаменну дату в угорській історії та історії регіону. У заяві правлячої партії Fidesz 3 нагоди 100-річчя Тріанона сказано: «100 років тому був підписаний Тріанонський мирний договір, щоб вирити могилу угорському народу. Вони захопили дві третини території історичної Угорщини, третину іiі населення і зруйнували іiї економіку. Жодна інша нація в світі не пережила подібну трагедію та каліцтв. Насправді, завдяки послідовному національному управлінню і національній співпраці протягом останніх десяти років ми, угорці, тут, у Карпатському басейні, стали зараз такі сильні, як ніколи. Сила й згуртованість угорців допоможуть нам подолати будь-яку кризу. Угорщина також зростає в економічному, фінансовому та культурному відношенні. Ось чому наші домашні й брюссельські ліві регулярно нападають на Угорщину. Вони не хочуть сильної, суверенної і національної ідентичності, що захищає Угорщину, а хочуть слабкої, втраченої ідентичності, завдяки якій можна економічно розграбувати 
Угорщину, прив'язати політично i, куди можна, ввезти мігрантів. Тому хочуть замінити національний уряд [Угорщини] маріонетковим урядом, що завершить місію Тріанона ... В обмін на владу та гроші вони готові відмовитися від національного суверенітету Угорщини, зруйнувати самобутність угорської нації, iї економічний і національний успіх» [3].

У своєму виступі в Шаторайяуйхее угорський прем'єр Opбан прямо назвав сили, які здійснили Тріанон. У зовнішньому світі - це Захід. Прем'єр Орбан виступив в Шаторайяуйхее 6 червня 2020 р. там, де поруч сходяться кордони Угорщини зі Словаччиною, Україною і Румунією - тими територіями, що були відрізаними від Угорського королівства Тріаноном.

«Захід згвалтував тисячолітні кордони й історію Центральної Європи. Наша країна була перетворена в будинок смерті. Вони перекроювали Центральну Європу без будь-яких моральних докорів сумління, як перекроювали кордони Африки і Близького Сходу. Ми ніколи цього не позбудемось. I коли ми думали, що горда Французька та Британська імперії і лицемірна Американська імперія більше не можуть опуститися ще нижче, так опустилися - після Другої світової війни ми були кинуті без жалю комуністам. Поляки, чехи, словаки були винагороджені тим, за що ми були покарані. Нехай це буде вічним уроком для народів Центральної Свропи. Тому що ті країни, які отримали вигоду від Тріанона, через цикл самі були покарані власними Тріанонами», - сказав Орбан.

А так Орбан висловився про внутрішніх руйнівників історичної Угорщини 1918-1919 років: «Багато людей добровільно погодилися поховати Угорщину. Хтось не хотів німців союзниками, хтось хотів помститися Габсбургам, хтось керувався наживою, а хтось завжди ненавидів угорців. Вони згуртувалися один з одним, щоб стерти нас з лиця землі» [4].

10 лютого 1947 року в Парижі союзниками антигітлерівської коаліції підписано договір з Італією, Болгарією, Угорщиною, Румунією і Фінляндією, котрі були змушені змиритися з втратою територій та необхідністю виплачувати репарації, що дозволило їм повернути собі права суверенних держав. Згідно 3 цими угодами Угорщина була відновлена в межах 1937 р. (оби- 
два Віденські арбітражі було визнано недійсними, скасування збільшення територій Угорщини за рахунок Чехословаччини і Румунії), за винятком трьох сіл на південь від Братислави, які були передані Чехословаччині. Насправді це була помста Сталіна за те, що угорці досить завзято воювали на боці Гітлера i були одними з найкращих вояків гітлерівської коаліції [5].

Для Угорщини це означало, що кордони з сусідніми країнами, закріплені Тріанонським мирним договором, залишаються незмінними 3 тією різницею, що Закарпаття, яке належало Чехословаччині, стало частиною СРСР, а саме УРСР.

Таким чином, угорці, з одного боку, опинилися за кордоном своєї Батьківщини, не змінюючи місця проживання, $з$ іншого - перетворилися з панівної нації на національну меншину, яка стала найчисельнішою меншиною у Свропі.

Так, сьогодні приблизно 3 млн угорців проживають за межами країни, з них: в Австрії - 25 тис. 884 ос., Румунії - 1 млн 639 тис., у Чехії - 20 тис. ос., у Словаччині - 520 тис. ос., у Сербській Воєводині - 350 тис. ос., в Україні - 151,5 тис. ос., У Словенії - 6 тис. 243 ос., у Хорватії - 14 тис. 047 ос. [6].

Колишньому прем'єр-міністрові Угорщини Йожефу Анталлу (1990-1993) належать слова: «Біль Тріанона стукає в серці кожного угорця» [1, с. 399].

Ця проблема $є$ і сьогодні досить чутливою для угорського суспільства, угорського політикуму. Тому серед населення досить поширені настрої образи за втрачені території та своїх співвітчизників, котрі не за своєю волею стали громадянами сусідніх держав. Ситуація, яка склалася у цій царині, породила за сто років їі існування надзвичайно складний комплекс моральнопсихологічних, етнокультурних, соціально-економічних, а отже, й суспільно-політичних проблем.

Тому цю проблему активно використовують у своїй риториці провідні угорські партії. I не дивно, що парламентська коаліція ФІДЕС - Угорський громадянський союз - Християнська демократична народна партія досить активно здійснює цю політику.

Горбачовська перебудова, початок розпаду СРСР, оксамитові революції кінця 80-х років у Центральній та Східній Свропі 
спонукали угорців до пошуку в регіоні такої країни, на базі якої можливо відпрацювати пілотний проєкт такого ставлення до угорської національної меншини, яке б відповідало найвищим європейським вимогам.

Такою країною виявилася Україна. По-перше, в УРСР у 1990 році вже були політичні сили, що прагнули до розпаду Радянського Союзу й розбудови незалежної держави. По-друге, така позиція вимагала забезпечення міжнародної підтримки та визнання. По-третє, значна кількість українців проживала i проживає за кордоном та потребує відповідної уваги, а в окремих випадках - захисту з боку прабатьківщини. По-четверте, українські угорці проживають компактно, головним чином у Берегівському, Ужгородському й Мукачівському районах, що надавало можливість у перспективі створити автономний національний округ.

Завдяки зусиллям угорської та української дипломатії у кінці травня - на початку червня 1991 року в Будапешті, під час візиту Голови Верховної Ради України Л.М. Кравчука, було підписано серед дев'яти українсько-угорських документів і Декларацію про принципи співробітництва із забезпечення прав національних меншин. Цей документ на сьогодні $є$ основою угорсько-українських відносин та політики щодо забезпечення прав національних меншин. Декларація на час ії прийняття своїми основними засадами була значно прогресивніша Декларації ООН про права осіб, що належать до національних або етнічних, релігійних і мовних меншин, яка була прийнята Генеральною Асамблеєю ООН у грудні 1992 року, Рамкової конвенції про захист національних меншин, Свропейської хартії регіональних мов або мов меншин.

Декларація підтвердила намір обох країн виконувати всі норми й зобов'язання, що є в Статуті ООН, документах про права людини ООН, Гельсінському заключному та інших документах про безпеку і співробітництво в Свропі.

Цей документ гарантував надання національним меншинам обох країн широкі права. Особливо варто наголосити на пункті 5 Декларації, в якому й Україна, й Угорщина взяли на себе зобов'язання створити для національних меншин такий 
статус, який забезпечував би їм ефективну участь у державних справах, включаючи участь у справах, що стосуються захисту і заохочення їхньої самобутності, прийняття та виконання рішень, які мають відношення до регіонів їхнього проживання [7, с. 269-274]. Із цього пункту випливає, що будь-яка 3 національних меншин, яка проживає в Україні чи Угорщині, має право на створення національно-культурної автономії, а за певних умов, за згодою центральної влади, також заснування адміністративно-територіальної автономії.

Важливим положенням, зафіксованим у Декларації, стало заснування змішаної комісії з представників державних установ i, відповідно, національних меншин обох країн. Комісія була створена 14 травня 1992 р. та діє на підставі Положення, затвердженого Постановою Кабінету Міністрів України 11 червня 1994 р. «Про Українську частину Змішаної українськоугорської комісії з питань забезпечення прав національних меншин». За більш ніж 28 років роботи комісія показала ефективність своєї роботи, її члени спромоглися вирішити велику низку питань забезпечення прав нацменшин обох країн, що значно сприяло зміцненню довіри між Україною та Угорщиною.

На сьогоднішній день правовою базою співробітництва в питаннях, які стосуються української національної меншини, $є$ міждержавні, міжурядові й міжвідомчі двосторонні документи, укладені Україною з Угорською Республікою, зокрема:

- Договір про основи добросусідства та співробітництва (31.05.1991 р.);

- Декларація про основні напрямки співробітництва в гуманітарній сфері (31. 05. 1991 р.);

- Декларація про принципи співробітництва по забезпеченню прав національних меншин (31. 05. 1991 р.);

- Угода між Урядом України та Урядом Угорської Республіки про співробітництво в галузі культури, освіти та науки (4. 04. 1995 р.);

- Угода про співробітництво у справі повернення культурних цінностей, що потрапили під час Другої світової війни та в наступні роки на територію іншої країни (4. 05. 1995 р.).

Таким чином, можна стверджувати, що в українсько-угор- 
ських стосунках створені всі політично-правові умови для того, щоб національні меншини обох країн відчували себе захищеними й, з одного боку, мали тісні стосунки з материнською нацією, 3 іншого - були забезпеченими в країні проживання всіма можливостями для розвитку культурних, освітніх та національних потреб нацменшин. Але для цього й Україна, й Угорщина повинні чітко виконувати взяті на себе зобов'язання у цій царині.

Захист прав угорських національних меншин, які проживають за кордоном, відповідають національним інтересам Угорщини і не змінюються протягом тридцяти років. Ще раз зазначаємо, що, незважаючи на зміну урядових коаліцій у Державних зборах, усі без винятку політичні сили, які були при владі, підтримували саме цей напрям. Серед комплексу проблем, пов'язаних із захистом прав угорців за кордоном, Будапешт велике значення приділяє освіті рідною мовою.

У грудні 1991 року прем’єр-міністр Угорщини Йожеф Анталл і Президент України Леонід Кравчук підписали у Києві Договір про основи добросусідства та співробітництва між Угорською Республікою і Україною. Це був фундаментальний документ, що визначив найважливіші зобов'язання обох сторін: відсутність територіальних претензій між двома країнами та гарантії захисту прав меншин [8]. Стаття 17 цього документа говорить про те, що договірні Сторони у повній відповідності 3 «Паризькою Хартією для нової Європи» й іншими відповідними документами Наради з безпеки і співробітництва в Свропі заявляють про свою переконаність у тому, що дружні відносини між їхніми народами, а також мир, справедливість, стабільність та демократія вимагають, щоб етнічна, культурна, мовна і релігійна самобутність національних меншин користувалася взаємним захистом та для іiі забезпечення повинні бути створені всі необхідні умови. Сторони вживатимуть односторонніх i спільних заходів для сприяння виконанню цих зобов'язань у відповідності з підписаним 31 травня 1991 року документом «Декларація про принципи співробітництва Української РСР і Угорської Республіки по забезпеченню прав національних меншостей» - та Протоколом до неї. Детально про ці документи сказано вище. 
В Україні забезпечення прав і свобод національних та етнічних меншин гарантовані Конституцією. Так, згідно зі статтею 11 «Етнонаціональну структуру українського суспільства становлять українська нація, корінні народи й національні меншини» [9]. Визнавши корінні народи та національні меншини окремими суб'єктами політико-правових відносин, Конституція поклала на державу обов'язок сприяти розвиткові їхньої етнічної, культурної, мовної і релігійної самобутності. Надаючи українській мові статус державної, Конституція одночасно гарантує вільний розвиток, використання й захист інших мов національних меншин України. Крім того, Конституція проголосила рівність громадянських прав і свобод незалежно від етнічного походження, мовних або інших ознак громадян України, їхнє право на свободу об'єднання у громадські організації для захисту своїх прав і свобод, задоволення культурних та інших інтересів [10].

25 червня 1992 року Верховна Рада України ухвалила Закон »Про національні меншини в Україні», згідно з яким Україна гарантує громадянам республіки незалежно від їх національного походження рівні політичні, соціальні, економічні й культурні права і свободи, підтримує розвиток національної самосвідомості й самовиявлення. Всі громадяни України користуються захистом держави на рівних підставах. При забезпеченні прав осіб, які належать до національних меншин, держава виходить 3 того, що вони є невід'ємною частиною загальновизнаних прав людини. Стаття 3 визначає, що до національних меншин належать групи громадян України, які не $є$ українцями за національністю, виявляють почуття національного самоусвідомлення та спільності між собою [11].

Окремі аспекти захисту прав національних меншин регулюються Законами України «Про мови в Українській РСР», »Про освіту», «Про друковані засоби масової інформації в Україні», «Про свободу совісті та релігійні організації», «Про місцеве самоврядування в Україні» тощо [12].

Але, на жаль, усі ці нормативно-правові документи не беруться до уваги можновладцями, коли мова заходить про політичні інтереси. Петро Порошенко йшов на президентські вибо- 
ри 2018 року з лозунгом «Армія. Мова. Віра». Головним чином, набір цих трьох компонентів був направлений на електорат Західної України, оскільки в інших частинах країни п'ятий президент підтримки не мав. Зупинимося тільки на мові. Ідеологам виборчої кампанії було вкрай необхідно продемонструвати радикально налаштованій частині виборців, що влада готова змусити говорити українською всіх громадян України. Для цього був прийнятий Верховною Радою 5 вересня 2017 року Закон «Про освіту», стаття 7 якого говорить про те, що особам, які належать до національних меншин України, гарантується право на навчання в комунальних закладах освіти для здобуття дошкільної та початкової освіти, поряд із державною мовою, мовою відповідної національної меншини. Це право реалізується шляхом створення відповідно до законодавства окремих класів (груп) 3 навчанням мовою відповідної національної меншини поряд із державною мовою і не поширюється на класи (групи) 3 навчанням українською мовою [13].

Таким чином, 3 п’ятого класу діти, які навчаються в угорських школах Закарпаття, повинні переходити на студіювання українською мовою. Лише зазначимо, що за часів, коли область була у складі Чехословаччини, знаходилася під фашистською окупацією Німеччини, була частиною СРСР, більш ніж 25 років в Україні угорська національна меншина мала можливість отримувати середню освіту рідною мовою. За урядування П. Порошенка таку можливість у них забрали.

Усе це було здійснено у спосіб, далекий від практики демократичних держав. Ніхто не порадився 3 керівництвом громадських організацій, які представляють інтереси угорської національної меншини. Ніхто не задумувався, а яким чином влада може забезпечити функціонування цих шкіл, де взяти таку кількість україномовних викладачів, як створити умови для їх роботи в угорськомовному середовищі. Й урешті-решт, які міжнародні наслідки цей Закон спричинить для України, як це вплине на українсько-угорські стосунки, у тому числі з урахуванням міжнародних зобов'язань країни.

Однак, Верховна Рада України в порушення міжнародних зобов'язань держави та Закону України «Про міжнародні дого- 
вори України», у статті 19 п.2 якого говориться про те, що якщо міжнародним договором України, який набрав чинності в установленому порядку, встановлено інші правила, ніжті, що передбачені у відповідному акті законодавства України, то застосовуються правила міжнародного договору [14], приймає 5 вересня 2017 року Закон «Про освіту». Стаття 7 цього документу говорить про те, що особам, які належать до національних меншин України, гарантується право на навчання в комунальних закладах освіти для здобуття дошкільної та початкової освіти, поряд із державною мовою, мовою відповідної національної меншини. Це право реалізується шляхом створення відповідно до законодавства окремих класів (груп) 3 навчанням мовою відповідної національної меншини поряд із державною мовою і не поширюється на класи (групи) 3 навчанням українською мовою.

Саме це положення Закону викликало шалену критику 3 боку офіційного Будапешта. Угорські урядовці та політики оцінили ці нововведення української влади як спробу асиміляції угорської національної меншини, позбавлення прав вільно володіти рідною мовою. У свою чергу, Міністр закордонних справ та зовнішньої торгівлі Угорщини П. Сіярто заявив, що його країна блокуватиме всі кроки в напрямку євроінтеграції України в рамках програми «Східного партнерства» та прагнення Києва до членства в НАТО [15].

Подальші кроки угорських високопосадовців стосовно України показали, що ці слова не були пустими погрозами.

Зразу після прийняття Закону в угорських ЗМІ розгорнулася потужна кампанія критики саме 7 статті цього документа. Тільки за місяць було надруковано 136 статей на цю тему.

Спробуємо проаналізувати, як же угорські масмедіа висвітлювали проблеми загострення двосторонніх стосунків між Україною та Угорщиною у зв'язку з прийняттям цього Закону. Для цього скористаємося матеріалами угорського порталу «Медіаомбудсман».

Дослідження проводилися на основі вивчення публікацій у ЗМІ з 06.09.2017 по 29.09.2017. Аналізувалися такі видання: 24.hu, 444.hu, 888.hu, alfahir.hu, hvg.hu, index.hu, mno.hu, origo. 
hu, zoom.hu. Кількість статей на кожному порталі була такою: 24.hu: 11, 444.hu: 12 cikk, 888.hu: 18, alfahir.hu: 16, hvg.hu: 14, index.hu: 11, mno.hu: 30, origo.hu: 12, zoom.hu: 12 .

Такий інтерес до цієї теми в Угорщині пов'язаний з тим, що драматургія цієї теми з угорського погляду проста - українські націоналісти прагнуть лишити угорців Закарпаття права вчитися на рідній мові, що викликало несприйняття й навіть гнів угорської громадськості. Причому в своїх різких оцінках були єдині як ліві, так і праві партії. У критичних матеріалах на цю тему ніхто з авторів не згадав, чому саме після 2014 року українці прийшли до гасла «не існує нації без мови», що саме російська агресія спонукала їх до рішучих дій із захисту української мови. Більшість публікацій на цю тему носили інформаційний характер і не відрізнялися глибоким аналізом. Аналіз був зроблений лише на Átlátsz.hu та на hvg.hu.

Публікації щодо Закону з'явилися в угорських ЗМІ з 6 вересня 2017 р. Але на той час було не зрозуміло, який текст був остаточно прийнятий ВР України. 7 вересня 2017 р. медіапортали повідомляли про одностайне засудження угорськими політичними партіями українського закону. Більшість угорських інформаційних джерел повідомили про заяву Міністра закордонних справ і зовнішньої торгівлі Угорщини Петера Сіярто в Таллінні про те, що Україна нанесла удар Угорщині в спину (444.hu, 888. hu, hvg, index.hu, mno.hu, origo.hu). У той же день масмедіа повідомили, що парламенти Румунії, Болгарії та кримські татари попросили Президента Порошенка накласти вето на Закон. 10 вересня 2017 року на alfahir.hu була оприлюднена заява партії Йоббік, у якій вони закликали всі опозиційні сили (444.hu, hvg. hu, mno.hu) приєднатися до протестів щодо дій української влади, організованих Загальним рухом країни (444.hu, 888.hu, hvg. hu, origo.hu, Zoom). До цієї акції ЗРК також запросили Fidesz, але пресслужба партії на це відповіла, що «ми не беремо участі у театрі ляльок Сороса» (hvg.hu).

10 вересня 2016 р. Петер Сіярто заявляє, що Угорщина не підтримає жодного важливого для України рішення на будьякому міжнародному форумі. Наступного дня він наказав послу Угорщини в Україні I. Ідярто відвідати МЗС країни та заяви- 
ти, що Будапешт вважає 7 статтю Закону про освіту «соромом і ганьбою» (888.hu, hvg.hu, mno.hu, zoom.hu).

11 вересня 2017 року Міністр закордонних справ України Павло Клімкін (про це повідомили 24.hu, mno.hu, Zoom) заявив, що Україна обіцяє поважати мовні права національних меншин. У той же день 444.hu, Alfahír, mno.hu, hvg.hu, origo.hu говорять, що всі п'ять угорських парламентських партій вважають Закон про освіту України неприйнятним.

11 вересня 2017 року Петер Сіярто звертається до чинного президента, Генерального секретаря та Верховного комісара ОБСС у справах національних меншин, Верховного комісара OОН з прав людини, Генерального секретаря Ради Свропи та Комісара ЄС $з$ питань політики сусідства 3 проханням вплинути на Україну з приводу питань освіти національних меншин (mno.hu).

У наступні два тижні в угорських новинах ця тема практично не заторкувалася. Причина цього була в тім, що угорські 3МІ не володіли повною інформацією про ситуацію в Україні й розраховували на те, що Порошенко через протести в сусідніх країнах не підпише Закон. Саме тоді стало очевидним протиріччя між українською та угорською (і певною мірою румунською та болгарською) позиціями.

Для українців головним аргументом введення 7 пункту Закону було те, що це направлено насамперед проти російської мови. В угорських масмедіа висловлювалася думка про те, що угорцям та іншим національним меншинам країн СС дозволить продовжувати навчання рідною мовою.

Під час виступу Президента України Петра Порошенка на Генеральній Асамблеї ООН 20 вересня 2017 р. він заявив, що діти, які належать до національних меншин, повинні «вільно» говорити українською мовою після закінчення початкової та середньої школи.

22 вересня 2017 р. Андрій Парубій, Голова Верховної Ради України, підписав Закон (444.hu, 888.hu, alfahir.hu, mno.hu).

22 вересня 2017 р. усі новинні портали повідомляли про те, що Порошенко підписав Закон про освіту (24.hu, 444.hu, 888 hu, Alfahír, hvg.hu, Index, mno.hu. origo.hu, масштабування). 26 
вересня 2017 р. усі ЗМІ також повідомили про відповідь Петера Сіярто: «Угорщина в Свропейському Союзі заблокує і накладе вето на будь-які кроки, які могли б представляти подальший прогрес України в процесі євроінтеграції в рамках програми «Східне партнерство».

Mno.hu пише найбільш детально про реакцію в Україні на цю заяву, а саме публікації під заголовками: «Не бійтеся угорської загрози», «Холодна війна Орбана»). Після МТІ речник Кремля Дмитро Песков також оприлюднив свою заяву, в якій засудив дії української влади (24hu, а 888.hu, Alfahír та origo. hu).

28 вересня 2017 p. Alfahír, Index пишуть про негативну реакцію угорської національної меншини Закарпаття на Закон про освіту.

Заголовок новин, що стосуються Закону про освіту, можна розділити на три типи. Перший - це пряме інформування (наприклад: «Угорські організації на Закарпатті протестують проти поправок проти меншості до Закону про освіту України» 444. hu). Другий - віддзеркалює угорську урядову позицію (Петер Сіярто: «Україна вдарила Угорщину в спину» 444.hu) та третій - пропагандистські спотворення («Український парламент проголосував: освіта угорською мовою на Закарпатті заборонена», Alfahír, «Президент України підписав Закон про освіту, який викликав велике обурення в світі» (hvg.hu). Насправді Закон про освіту викликав обурення лише у чотирьох країнах: Угорщині, Молдові, Румунії, Росії. У даному випадку МTI вважає за необхідне показати реакцію в Угорщині як таку, що розділяє та підтримує увесь світ.

У подальшому темі освіти угорською мовою в Закарпатті ЗМІ Угорщини приділяли постійну увагу. Правда, ці матеріали публікувалися не так часто, як це було після прийняття Закону. Але тональність цих матеріалів у більшості випадках зберігалася. Наведемо тільки декілька прикладів. У липні 2018 року Андраш Ковач друкує на сторінках Інтернет-порталу origo.hu статтю «Закон про освіту: коли Президент України виконає свою обіцянку?» [16]. Автор наголошує на тому, що Президент України Петро Порошенко підписав підсумкову декларацію на 
саміті Україна - СС про те, що Закон про освіту країни повинен гарантувати права осіб, які належать до національних меншин, відповідно до міжнародних зобов'язань України.

3 ухваленням нового Закону про освіту добросусідські стосунки з Угорщиною закінчилися, хоч Будапешт був палким прихильником інтеграції України в СС та НАТО. Угорці підтримали угоду про відмову від віз між ЄС і Україною, одними з перших ратифікували Угоду про асоціацію Україна - СС.

Прийнятий Закон також суперечить європейським цінностям, міжнародним зобов'язанням України, Угоді про асоціацію між Україною та ЄС, Плану підготовки України до НАТО й двостороннім угодам. Перелічені угоди стверджують, що попередньо набуті права меншин не можуть бути відібрані. Однак, Україна робить це саме так.

В Україні 16 липня 2019 року набув чинності Закон «Про забезпечення функціонування української мови як державної». Закон, підписаний президентом Петром Порошенком 15 травня, за чотири дні до завершення його повноважень викликав безліч питань у відносинах із європейськими партнерами. I йдеться не лише про Угорщину, яка бачить у ньому чергові утиски прав угорської меншини на Закарпатті й тому була найяскравішою у претензіях до України. Було наперед відомо, що Закон критикуватиме також Свропейський Союз, який багаторазово та наполегливо просив Київ надіслати його на перевірку до Венеціанської комісії. Українська влада відмовлялася це робити, тим самим лише підтверджуючи: автори документа усвідомлюють, що критики Закону не уникнути.

Зрештою Закон потрапив до «Венеціанки» навіть проти волі України, а 6 грудня та завершила процедуру й ухвалила свої рекомендації. У чому їх суть.

Те, що державна українська мова повинна мати особливий статус і захист, у Раді Свропи повністю підтримують. I що особливо важливо, там усвідомлюють, що за часів СРСР вага російської мови на території України була суттєво вищою, і тому зараз державна мова вимагає додаткової підтримки. Одна з головних претензій експертів Ради Свропи до України - це брак ясності у тому, як будуть застосовуватися норми нового Закону 
на практиці та який захист отримають мови меншин. У тому числі через те, що проєкт Закону «Про меншини», який Рада зобов'язалася ухвалити не пізніше початку 2020 року, досі не поданий до парламенту.

Один із прикладів неясності, який наводить ВК, стосується норми про те, що «кожен громадянин України повинен володіти державною мовою». Це загалом правильна норма, зауважують у «Венеціанці». «Однак не зовсім зрозуміло, які наслідки чекають на громадян, які не виконують цю вимогу».

На думку експертів ВК, у низці випадків Закон про мову дозволяє навіть притягати людей до кримінальної відповідальності без чітко прописаних підстав.

Окремий блок претензій стосується застосування мов меншин державними посадовцями, які діють у екстрених випадках. Венеціанська комісія вітає те, що «в галузі охорони здоров'я, медичної допомоги та медичних послуг» Закон дозволяє на прохання особи надавати послуги не державною мовою. Але висновок ВК ставить питання: чому йдеться лише про медицину?

«Таку ж можливість варто надати всім службам, які працюють у надзвичайних ситуаціях, що становлять загрозу для життя, для фізичного чи психічного стану людей, наприклад, служби порятунку, пожежників тощо. Сюди також слід віднести установи для людей похилого віку, які не обов'язково є медичними закладами - оскільки такі особи часто належать до меншин і можуть не мати достатнього рівня володіння українською», - йдеться у висновках «ВенеціаТак само (і цілком доречно) ВК наголошує, що іноді є потреба спілкуватися не лише українською мовою 3 правоохоронцями чи навіть представниками армії. I тут доречно згадати про неслов'янські угорську та румунську меншини, представникам яких (особливо дорослим і людям похилого віку) може бути об'єктивно складно оволодіти українською.

«Венеціанка» зауважує, що у районах компактного проживання таких меншин (у тому числі в угорських містечках та селах) «держслужбовці могли б надавати державні послуги, особливо ті, що стосуються надзвичайних ситуацій, як українською, так і мовами меншин». ВК також нагадала, що це зобов’язання України перед Радою Свропи. 
А ще, на думку ВК, Закон встановлює занадто жорсткі вимоги для політичних партій та об'єднань громадян, зобов'язуючи їх приймати свої рішення виключно українською.

«Цей обов'язок є обмеженням свободи асоціацій, що тягне за собою право на самоорганізацію. Таке обмеження служить законній меті громадського порядку, оскільки робить можливим нагляд державними органами за діяльністю партій, асоціацій та інших юридичних осіб... Однак термін «установчі документи та рішення» не $\epsilon$ зрозумілим... Ця вимога повинна обмежуватися лише тими документами та рішеннями, які стосуються публічних функцій», - ідеться у рішенні ВК.

Насамкінець, варто виділити претензії «Венеціанки» щодо обмеження мови масмедіа, яких у рішенні чимало. Мовний закон посилює вимоги до мовних квот, збільшуючи частку вмісту української мови для національних та регіональних мовників із 75 до 90 відсотків, а для місцевих мовників - від 60 до 80 відсотків.

«Оскільки ці положення застосовуються і до приватних телерадіокомпаній, вони обмежують право на свободу вираження поглядів та право осіб, які належать до національних, релігійних та мовних меншин, на використання власної мови або культури... Вони залишають дуже мало місця для використання мов меншин», - вважає «Венеціанка», зауважуючи, що це рішення порушує положення низки міжнародних конвенцій, учасником яких є Україна. Також ВК виступає проти зобов'язання, накладеного на друковані засоби масової інформації, щодо випуску також україномовної версії [17].

Усі ці претензії та зауваження до українського Закону, що викладені в рішенні Венеціанської комісії, повністю підтримує i бере на озброєння угорська влада. Згодні з нею керівники громадських організацій угорців Закарпаття. Відповідна реакція була і в ЗМІ Угорщини.

Прийняття Закону «Про забезпечення функціонування української мови як державної» і його вплив на ситуацію з освітою угорською мовою в Закарпатті уважно відслідковувалося 3МI Угорщини. Наведемо лише декілька прикладів.

Так, новинний Інтернет-портал hvg.hu надрукував цілу низку статей на цю тему. Серед них назвемо «Угорські організації 
Закарпаття неодноразово протестували проти закону, оскільки вважають, що він скасовує всі мовні права меншин».

Президент Петро Порошенко підписав Закон про українську мову та повторив, що Закон про функціонування української як державної мови жодним чином не посягає на інші мови. Він також заявив, що сподівається, що після інавгурації обраного Президента Володимира Зеленського нове керівництво України - після аналізу законодавства - на практиці застосує норми, закріплені в Законі. У свою чергу, Товариство угорської культури Закарпаття (KMKSZ) та Угорський демократичний союз України (UMDSZ) у спільному листі попросили Порошенка не підписувати Закон про мову, оскільки вони вважають, що він принципово порушує права громадян України і значно погіршує становище угорської національної меншини [18]. «Парламент України відмовився від пропозицій про скасування Закону про мову, і зараз спікер Андрій Парубій також підписав документ. У документі відсутній лише підпис Президента Петра Порошенка».

Закон про українську мову, підданий критиці меншин, був підписаний спікером Андрієм Парубієм у вівторок після того, як парламент відхилив усі чотири пропозиції щодо скасування Закону. Закон про функціонування української мови як державної був прийнятий парламентом 25 квітня 2019 р. Угорські організації на Закарпатті жорстко протестували проти Закону, оскільки вони вважають, що він скасовує всі мовні права меншин. Закон зобов'язує використовувати українську мову практично скрізь, окрім приватних розмов та релігійних обрядів, i передбачає юридичну відповідальність та штрафи за порушення у використанні української мови правил і навіть позбавлення волі за її образу [19].

«Український парламент проголосував за законодавство, проти якого останнім часом гаряче протестують угорські організації на Закарпатті, оскільки вони вважають, що це скасує всі існуючі мовні права меншин».

За даними українських інформаційних агентств, для прийняття Закону було потрібно щонайменше 226 голосів, але його підтримали набагато більше - 278, у тому числі 106 депутатів 
партії Петра Порошенка». У Законі зазначено, що «мовні інспектори» забезпечуватимуть дотримання Закону. Голова Товариства угорської культури Закарпаття (KMKSZ) Ласло Брензович днями заявив УТА, що проєкт Закону є неприйнятним, оскільки він скасує всі мовні права меншин, якими вони користувалися досі [20].

Одна 3 провідних угорських газет Nepszava також значну увагу приділила висвітленню цієї теми. Ось тільки декілька публікацій, які з'явилися після прийняття Закону. «Угорська пропозиція щодо декларації НАТО-Україна була прийнята». Угорці Закарпаття ніколи не були у такій скрутній ситуації після того, як Президент Порошенко підписав Закон про українську мову. Держави-члени НАТО та Україна прийняли пропозицію Угорщини щодо відображення у спільній заяві НАТО-Україна угорської позиції щодо Закону. Як заявив Міністр закордонних справ та торгівлі Угорщини П. Сіярто, «Зрештою, наші пропозиції були враховані, спільна заява рішуче підтримує угорську громаду та закликає Україну дотримуватися міжнародних правил та стандартів міжнародних організацій у цій царині» [21]. «В Україні дуже суперечливий Закон про мову розслідує делегація Венеціанської комісії». Після візиту експертів Венеціанська комісія підготує висновок щодо імплементації Закону, який, як очікується, буде ухвалений правлінням на своєму грудневому засіданні, - пише УТА. Делегацію прийняв заступник Міністра закордонних справ України Василь Боднар. За інформацією Мiністерства закордонних справ, на зустрічі дипломат наголосив, що Закон прийнятий відповідно до Української Конституції, спираючись на досвід зарубіжних країн та попередні рекомендації Венеціанської комісії. За словами Боднара, прийняття такого законодавства було важливим не лише з гуманітарного погляду, але й з погляду безпеки через триваючу російську агресію проти України [22]. «Закон про мову, який піддався критиці національних меншин України та кількох міжнародних організацій, у вівторок підписав спікер парламенту Андрій Парубій, після того як законодавча влада відхилила подання опозиційних депутатів». Таким чином, Глава держави Петро Порошенко мав можливість підписати підтримане ним законодавство. Хоча 
міжнародні організації, включаючи Свропейський Союз, висловили застереження щодо Закону та закликали Київ звернутися за рішенням до Венеціанської комісії, цього не було зроблено. Обраний Президент Володимир Зеленський не підтримує цей Закон [23]. «Помста невдахи: Остання дія Порошенка порушує основні права нацменшин». Хоча Петро Порошенко пообіцяв поважати права нацменшин, Закон про мову, ухвалений у четвер, все одно буде штрафувати за використання рідної мови. Президент, який покидає свій пост і який поставив інтеграцію в СС як мету країни в Конституції та зазнав нищівної поразки на виборах президента, в останній тиждень своєї роботи підписав Закон, який іде проти духу СС, порушуючи основні права національних меншин. У парламенті, де Блок Порошенка досі перебуває в більшості, Закон підтримала майже кожна фракція, крім Опозиційного блоку [24]. Інтернет-портал 444.hu також досить докладно інформує читачів про український мовний закон. Назва статей: «П. Сіярто: Питання Закону про українську мову буде вирішено, коли воно буде прийнятне для угорців Закарпаття», «Конституційний Суд України визнав мовний закон про розширення прав меншин неконституційним», «Український Президент-переможець виборів Зеленський по-іншому ставиться до Закону про українську мову, ніж колишній лідер». Популярний Інтернет-портал 24.hu також активно висвітлював інформацію про мовний закон в Україні. Ось лиш декілька назв інформаційних повідомлень: «Зеленський вивчить Закон про мову», «Суперечливий Закон про мову був прийнятий українським парламентом», «Український уряд завдає шкоди угорцям Закарпаття», «Закон про мову: Україна відмовляється відповідати на вимоги Будапешта», «Угорські партії протестують разом проти Закону про українську мову». Перелік угорських масмедіа та статей, повідомлень, аналітичних матеріалів, які стосуються Закону «Про забезпечення функціонування української мови як державної» можна було б продовжити. Але для них загальним $є$ те, що всі вони незалежно від лівої чи правої направленості, провладної позиції чи опозиції гостро критично сприймають будь-які спроби створити перешкоди у використанні угорської мови угорцями, які проживають в Україні. 
Нову хвилю обурення угорської влади, наукової спільноти та загалом суспільства викликав прийнятий 16 січня 2020 року Верховною Радою України Закон про повну загальну середню освіту.

04 лютого 2020 р. Угорська академія наук прийняла постанову про проєкт Закону про мову в Україні, про що було повідомлено в УТА [25]. У цьому документі говориться про те, що з часу заснування Угорської академії наук вона відповідає за вільне використання угорської мови, а також за захист культурної та національної самобутності як в Угорщині, так і поза іiі межами. Академія стурбована тим, що проєкт Закону суворо обмежує право угорської меншини, яка проживає в Україні, вивчати угорську мову. Якщо він набуде чинності, Закон перешкоджатиме конструктивній інтеграції угорськомовного населення в українське суспільство. Право на навчання рідною мовою $\epsilon$ правом для культурної спільноти від дошкільної до університетської, від дитини до молоді. Постійне навчання мовою меншин у мультикультурному світі $є$ і гарантією виживання меншинних спільнот, і запорукою гармонійного розвитку особистості в цьому мовному та культурно складному світі. 05 лютого 2020 р. на сайті valaszonline.hu 2020.02.05 з'явилася стаття Барна Борбаша «В Україні реально нове безправ'я: 10 пунктів щодо закону, що задушує угорську освіту» [26].

У цій публікації мова йшла про Закон про повну загальну середню освіту, прийнятий Верховною Радою 16.01.2020р. Угорський журналіст «Valaszonline» звернувся до професора Іштвана Черничко, який очолює Дослідницький центр лінгвістики імені Антала Ходінки в Берегово, з проханням дати експертну оцінку 3 цього питання. У цьому документі, - зазначив науковець, - як і в 7 статті закону про освіту 2017 року, говориться про те, що навчання рідною мовою можуть отримувати представники національних меншин з країн $\mathrm{CC}$, а це угорці, румуни, поляки, болгари, у початкових школах, тобто 1-4 клас навчаються рідною мовою, а вже з 5 класу, з кожним роком кількість годин, які будуть викладатися державною мовою, буде збільшуватися. Далі угорський учений розказує про те, що Угорщина добилася від української влади перенесення термінів упровадження Зако- 
ну з 2023 року, а також про те, що в угорських школах не створені умови для вивчення української мови та літератури. Загалом у статті знову наголошується на тому, що Україна прийнятим Законом знову порушує свої міжнародні зобов'язання, які випливають із Європейської хартії регіональних мов або мов меншин, ратифікованої ВР країни у 2003 році. 4 лютого 2020 року на Інтернет-порталі index.hu була надрукована стаття «Що буде з вами, угорці Закарпаття?» [27]. У ній говориться про те, що в Україні прийнято новий Закон про освіту, і майже всі в Угорщині хвилюються за угорців, які тут проживають. Цим документом створено нові проблеми для угорців Закарпаття в отриманні середньої освіти рідною мовою. У публікації наголошується, що Міністерство закордонних справ Угорщини протестувало проти Закону про освіту 2017 р. та Закону про повну загальну середню освіту, прийнятого Верховною Радою 16.01.2020 р., на всіх міжнародних форумах. У той же час, дипломатичне відомство Угорщини сподівалося, що обраний у квітні 2019 р. новий Президент Володимир Зеленський скасує дію цих Законів, але ці надії не були виправдані. Натомість Угорщина з тих пір блокує вступ країни Східної Європи до НАТО. У статті «Київ прийняв поправку до Закону про освіту», яка була надрукована в газеті «Мадяр Хірлоп» 16 січня 2020 року також аналізується Закон про середню освіту [28]. Потрібно зазначити, що це одна 3 небагатьох публікацій, у якій інформація подана спокійним, неупередженим тоном. У вищезгаданому матеріалі сказано, що у грудні 2017 року Венеціанська комісія Свропейської Ради запропонувала Києву низку рекомендацій, для того щоб збалансувати Закон про освіту відповідно до міжнародних документів щодо захисту прав нацменшин. Вони включали перенесення виконання Закону до 2023 року, що український уряд прийняв 14 лютого 2018 року. Прийнявши нещодавно Закон про середню освіту, Київ стверджує, що виконав усі рекомендації Венеціанської комісії. Згідно з пресрелізом Міністерства освіти, мовна стаття Закону була розроблена після консультацій з представниками національних меншин з урахуванням рекомендацій Венеціанської комісії Ради Свропи. Закон поділяє меншини, які проживають в Україні, на три групи та визначає освіту, яка 
вважається для них відповідною. Прийнятий Закон дає право приватним школам самим обирати мову навчання, одночасно забезпечуючи вивчення української мови. У статті детально інформується про позицію віцепрем'єр-міністра України з питань європейської інтеграції Дмитра Кулеби щодо прийняття нового Закону. Особливий наголос робиться на його слова, що цей Закон допоможе покращити відносини між Україною та Угорщиною. 29 червня ц.р. заступник Міністра закордонних справ В. Боднар повідомив, що у кінці липня можуть зустрітися Президент України В. Зеленський та Прем’єр-міністр Угорщини В. Орбан [29]. Однак, ця зустріч не відбулася.

Про те, коли може відбутися візит прем'єр-міністра Угорщини Віктора Орбана в Україну, повідомив Посол Угорщини в Україні Іштван Ійдярто. Однак, як зазначив у інтерв'ю виданню «Інтерфакс-Україна» Посол Іштван Ійдярто, візит Віктора Орбана в Україну відбудеться, «коли умови дозволять». За словами дипломата, угода про дорожню карту, яка веде до візиту, полягала в постійних розмовах двох Міністрів закордонних справ - Дмитра Кулеби та Петера Сіярто, «які будуть рушіями відновлення або регулювання наших відносин». «Вони погодилися, що деякі інституції мають розпочати роботу, щоб ідентифікувати проблеми, відкрити шлях для подальших переговорів, двосторонніх зустрічей. $С$ три найважливіші 3 них: перша інституція - це міжурядова змішана економічна комісія, яка була паралізована у зв'язку з цією неприємною ситуацією у двох країнах. Незважаючи на це, в них був дуже довгий список тем, які не могли просуватися», - пояснив Ійдярто. Другою інституцією Ійдярто назвав спільну комісію з питань меншин, яка $€$ однією з найдавніших інституцій між двома країнами. I третє - найболючішими є теми, пов'язані з використанням мови, й особливо щодо освіти. Ми маємо звернутися до експертів, щоб також обговорити цю проблему. Це елементи, які допомогли прокласти шлях до зустрічі на найвищому рівні. Він зазначив, що зустріч співголів українсько-угорської комісії з питань національних меншин 14 липня була «абсолютно своєчасною і важливою», та водночас переважно процедурною й практичною. Ійдярто нагадав, що повної сесії цієї комісії не було з 2011 
року, а зустрічі співголів - з 2017 року. «Це дуже обнадійливо, це означає, що щось розпочалося. Угорщину кілька разів звинувачували, що ми намагаємося надати міжнародного характеру цьому конфлікту. Це не так. Наразі цей процес розпочинається, у нас $є$ партнер. Українська сторона зазначила, що після кількох реорганізацій у них є складнощі з формуванням необхідних учасників комісії, більшість державних інституцій, пов'язаних iз питаннями меншин, усе ще формуються. Але вони пообіцяли, що в серпні або вересні будуть призначені перші члени 3 української сторони. Тому є можливість, що восени комісія зможе зустрітися», - сказав він. Говорячи про те, коли очікувати засідання комісії з питань освіти, Ійдярто зазначив, що Міністерства освіти обох країн «незабаром домовляться, коли зможуть провести засідання» [30].

Потрібно зазначати, що при тому, що питання угорської меншини надалі відіграє значну роль у формуванні двосторонніх міждержавних українсько-угорських відносин, питання захисту прав меншин з об'єднуючого, цементуючого чинника, яким видавалося у часи початку цих відносин, поступово перетворюється у деструктивну проблему між державами. I, напевно, є найбільш тривожним те, що така атмосфера недовіри з висоти міжурядових стосунків поступово поширюється як у середовищі політикуму, так і громадськості двох сусідніх, безумовно приречених на дружбу й співпрацю сусідніх держав.

Українська влада, політикум повинні зрозуміти, з урахуванням угорської історії, що будь-яке угорське керівництво буде проводити політику захисту своєї національної меншини у сусідніх країнах і у тому числі у Закарпатті. Це можливо використати на користь України, а, ймовірно, навпаки через безглузду політику - на шкоду. Надзвичайно актуальним є знайдення правильного алгоритму для задоволення освітянських потреб угорської меншини. Тут потрібно враховувати специфіку угорської мови, яка належить до угро-фінської мови та входить до уральської мовної сім'ї і повністю відрізняється від української мови. Тому вимагати від випускників угорських середніх шкіл такого знання української мови, як і українських школярів, означає закрити їм шлях до українських ВНЗ. Необхідно також на 
державному рівні розробити програму підтримки задоволення культурних, освітянських, мовних потреб угорської національної меншини Закарпаття. Цим самим ми створимо сприятливий клімат в українсько-угорських стосунках, а це, у свою чергу, вплине і на позицію щодо України і керівництва Угорщини.

\section{Література}

1. Ткач Д. Сучасна Угорщина в контексті суспільних трансформацій: Монографія. - К.: МАУП, 2004. - 480 с.

2. Віце-прем'єр Угорщини: «Автономія - мета та майбутнє закордонних угорських меншин» URL: http://www.mukachevo.net/ua/ news/view/197237

3. Трианон 100: «Примирение» в «Карпатском бассейне» не состоялосьһttps://eadaily.com/ru/news/2020/06/09/trianon-100primirenie-v-karpatskom-basseyne-ne-sostoyalos

4. Orbán Viktor ünnepi beszéde https://www.kormany.hu/hu/aminiszterelnok/beszedek-publikaciok-interjuk/orban-viktor-unnepibeszede 1

5. Парижський мний договір. https:/www.jnsm.com.ua/h/0210P/ ?fbclid=IwAR2rFiaCR1BfeFUgCbQ1 vzpbBgJ89a6WG_5XOsZnkSaf bhQWSz1T5qcSCbo

6. Шипка Н. Угорська національна меншина як чинник формування українсько-угорських міждержавних політичних відносин (1991-2006 рр.) - Львів : Видавництво Національного університету «Львівська політехніка», 2007. - Вип. 19. - С. 208-216.

7. Декларація про принципи співробітництва між Українською Радянською Соціалістичною Республікою та Угорською Республікою по забезпеченню прав національних меншостей // Збірник чинних міжнародних договорів України. - Т.1. - К., 2001. С. 269-274.

8. Договір був укладений 6 грудня 1991 р. і набув чинності 16 червня 1993 р. Ратифіковано Постановою ВРУ N 2527-XII (252712) від 01.07.92 // Відомості Верховної Ради України (ВВР), 1992, N 37, ст. 552.

9. Конституція України. Відомості Верховної Ради України (ВВР), 1996, № 30, ст. 141.

10. Україна: утвердження незалежної держави (1991-2001). - К.: «Альтернативи», 2001. - С. 385. 
11. «Про національні меншини в Україні». Відомості Верховної Ради. - К. 1992, №36. - С. 529.

12. Україна: утвердження незалежної держави (1991-2001). - К.: «Альтернативи»,2001. - С.385.

13. Закон України Про освіту (Відомості Верховної Ради (ВВР), 2017, № 38-39, ст.380).

14. Закон України Про міжнародні договори України (Відомості Верховної Ради України (ВВР), 2004, № 50, ст. 540)

15. Угорщина продовжить блокувати засідання Комісії УкраїнаНАТО, - Сіярто https://day.kyiv.ua/uk/news/100320-ugorshchynaprodovzhyt-blokuvaty-zasidannya-komisiyi-ukrayina-nato-siyarto

16. Закон про освіту: коли Президент України виконає свою обіцянку?/ https://www.origo.hu/nagyvilag/20180710-ukrajna-natocsucs-magyarsag-helyzete-karpatalja.html

17. Венеційська комісія розкритикувала мовний закон: які зміни рекомендують Україні https://zmina.info/articles/veneczianskakomisiya-rozkrytykuvala-movnyj-zakon-yaki-zminy-rekomenduyutukrayini/

18. A törvény ellen több ízben hevesen tiltakoztak a kárpátaljai magyar szervezetek, mert szerintük felszámolja a kisebbségek valamennyi eddigi nyelvi jogát. https://hvg.hu/vilag/20190515_ukran_ nyelvtorveny_alairas_petro_porosenko

19. Leszavazta az ukrán parlament a nyelvtörvény visszavonására irányuló javaslatokat, és most Andrij Parubij házelnök is aláírta a dokumentumot. Már csak Petro Porosenko elnök kézjegye hiányzik a dokumentumról https://hvg.hu/vilag/20190514_Alairta_az_ukran_ nyelvtorvenyt_a_hazelnok

20. Az ukrán parlament megszavazta a jogszabályt, amely ellen a közelmúltban hevesen tiltakoztak a kárpátaljai magyar szervezetek, mert szerintük felszámolja a kisebbségek valamennyi eddigi nyelvi jogát. https://hvg.hu/vilag/20190425_ukran_parlament_nyelvtorveny_ elfogadas

21. Elfogadták a magyar javaslatot a NATO-Ukrajna nyilatkozathoz https://nepszava.hu/3055564_elfogadtak-a-magyar-javaslatot-a-natoukrajna-nyilatkozathoz

22. Ukrajnaban vizsgalja a sokat vitatott nyelvtorvenyt a Velencei Bizottsag kuldottsege https://nepszava.hu/3055050_ukrajnabanvizsgalja-a-sokat-vitatott-nyelvtorvenyt-a-velencei-bizottsagkuldottsege 
23. Aláírta az ukrajnai nemzeti kisebbségek és több nemzetközi szervezet által is bírált nyelvtörvényt kedden a kijevi parlament elnöke, Andrij Parubij, miután a törvényhozás elutasította az ellenzéki képviselök beadványait. https://nepszava.hu/3035944_szabad-utatkapott-az-ukran-nyelvtorveny

24. A vesztes bosszuja: alapveto jogokat sert Porosenko utolso intezkedese. nepszava.hu Publikálás dátuma 2019.04.26.

25. Постанова MTA про проект закону про мову в Україні https:// mta.hu/mta_hirei/a-magyar-tudomanyos-akademia-allasfoglalasa-azukrajnai-nyelvtorvenytervezetrol-110314

26. «В Україні реально нове безправ'я: 10 пунктів щодо закону, що задушує угорську освіту». https://www.valaszonline.hu/2020/02/05/ ukrajna-oktatasi-torveny-nyelvtorveny-karpatalja-szabalyozas/

27. «Що буде 3 вами, угорці Закарпаття?» https://index.hu/ kulfold/2020/02/04/mta_ukrajna_oktatasi_torveny_nyelvtorveny_ allasfoglalas/

28. Київ прийняв поправку до Закону про освіту https://www. magyarhirlap.hu/kulfold/20200116-kijev-elfogadta-az-oktatasitorveny-modositasat

29. Встреча Орбана и Зеленского может состояться в конце июля - замглавы МИД Боднар. https://interfax.com.ua/news/ political/671713.html

30. «Коли дозволять умови»: запланована раніше зустріч Зеленського і Орбана відкладається. http://www.mukachevo.net/ua/news/ view/1955772 


\section{Висновки}

Монографія є системним дослідженням угорської журналістики з часів її заснування 1705 року і по сьогоднішній день. У роботі представлена модель взаємодії влади і суспільства через 3МI, ведення суспільно-політичного діалогу на сторінках найважливіших медіаресурсів Угорщини, характерне для Центрально-Східного європейського регіону. В якості основних джерел взяті практично всі масмедіа Угорщини, від друкованих - газет та журналів до електронних - радіо, телебачення, Інтернет-видання, на сторінках яких представлені різні типи публіцистичних текстів. Аналіз друкованих матеріалів, підкріплений аналізом подій, що призвели угорську журналістику до iї сучасного вигляду, показує, що вона має багато спільних рис 3 європейськими масмедіа, та у той же час у неї $є$ і специфічні ознаки, породжені як національною культурою, так і національними традиціями.

Зміни на ринку друкованих видань Угорщини після падіння Берлінської стіни (1989р.) та зміни, які відбулися з цими трансформаціями в системі власності, способах управління i фінансування, призвели й до зміни змісту газет і журналів, що не могло не позначитися на діяльності журналістики загалом.

Сучасну угорську публіцистику неможливо розглядати самостійно, у відриві від процесу їі становлення й розвитку, оскільки вона є унікальним продуктом, чимось схожим, чимось не схожим на публіцистику інших країн Центральної та Східної Свропи. Це пов'язано з особливістю ведення суспільно-політичного діалогу на сторінках видань, а також з особливостями угорської мови, угорської культури, нації і з тим історичним досвідом, який вона пережила. Створення першої газети Угорщини під назвою Magyar Merкúr у 1705 році було продиктовано бажанням 
угорської знаті впливати на громадську думку й брати участь в управлінні економічними і політичними процесами, просвічуючи націю. Авторська позиція, закладена в перших газетних матеріалах XVIII ст., збереглася і в публіцистичних статтях сучасних видань. Якщо в XVIII ст. угорські газети вперше побачили світ, пережили хвилю популярності, кризу, пов'язану з наростанням революційних настроїв у Свропі, натиск Йосипа II, то в ХІХ ст. вони переживають новий етап розквіту, а в самому кінці століття угорські газети стають по-справжньому масовими. Змінюється не тільки склад редакції, а й стиль викладу інформації, значну роль у передових виданнях починають відігравати письменники, що активно продовжиться в ХХ столітті.

В Угорщині завжди знаходилися люди, здатні грамотно i красиво, а головне дохідливо пояснити зі сторінок газет, чим $\epsilon$ сучасна дійсність для них, угорців, чого варто побоюватися, кому і чому можна довіряти. Через події, що насичували зміни епох і державних систем, не можна однозначно визначити якийсь єдиний піковий момент, коли панувала на загальносуспільному Олімпі публіцистика. Такі моменти були і в XIX ст., коли в період ідейної підготовки і напередодні революції 18481849 рр. значним впливом володіла публіцистика Лайоша Кошута. Відповідно до думки відомого вченого, соціолога та публіциста Пала Тамаша, слід виділяти такі «золоті періоди» в розвитку угорської публіцистики в ХХ ст. По-перше, роки перед Першою світовою війною, які були важкими, але яскравими, емоційними для всієї журналістики загалом. На чуттєвому, інтуїтивному рівні й журналісти, і літератори усвідомлювали невідворотність великих змін. Цей період також підготував посправжньому цінні 1920-і та 1930-і рр. Про наступні періоди зазначимо далі.

Початок періоду 1918-1945 років характеризувався тим, що структура влади й уряду була повністю змінена, все більше революційних хвиль $з$ протилежними ідеологіями слідували одна за одною. Кожен новий уряд вимагав беззастережної підтримки від преси і у той же час вимагав від журналістів відповіді, чому вони працювали на попередніх керманичів. Таким чином, період, коли угорська преса діяла за загальноєвропейськими нор- 
мами, закінчився. Від неї вимагали брати участь у політичній боротьбі.

Після того, як 21 березня 1919 року до влади в Угорщині прийшли комуністи, вони встановили жорстку цензуру на діяльність 3MI, багато з яких були просто закриті.

Після поразки більшовицької революції, у 1920-х роках, під час уряду Бетлена, контроль над пресою повернувся до ліберальної традиції доби дуалізму. Хоча були деякі заборони на газети Újság, Világ, однак іншим часописам було надано державні субсидії, особливо це допомогло провінційній пресі.

1 вересня 1939 року прем'єр-міністр Пал Телекі, у зв’язку 3 початком Другої світової війни, оголосив надзвичайний стан, що означало, серед іншого, введення цензури преси та зменшення кількості газет.

Постанова уряду від 28 серпня 1940 р. значно розширила цензуру на всі види преси і включила до Комітету з цензури, крім представників прокуратури, Кабінет прем’єр-міністра, Мiністерства оборони, фінансів, закордонних справ та Генеральний штаб. Цензура провінційної преси здійснювалася місцевими прокурорами разом з поліцією.

З 1941 по 1944 роки, і до німецької окупації, концентрація влади у медіасфері, введення жорсткої цензури дозволили продемонструвати німцям, що їх вимоги до контролю над пресою виконуються.

Подальша німецька окупація Угорщини скасувала подвійність контролю над пресою, і навіть значною частиною угорської преси.

У жовтні 1944 року радянські війська вступили на територію Угорщини, розпочалося звільнення країни від німецької окупації. На наступний день після визволення Пешта від фашистів у столиці, 19 січня 1945 р., під контролем комуністів була започаткована газета Szabadság, яка видавалася щоденно. Комуністичні журналісти газети вперше зіткнулися 3 радянською цензурою, коли вони хотіли виступити проти жорстокостей окупаційних російських військових. Ерньо Геро - один із керівників комуністичної партії, був категорично проти найменшої критики в бік Червоної армії. У перші дні стало зрозу- 
міло, що свобода преси, принаймні, що стосується Радянської армії, не працює.

Таким чином, період 1918 - 1945 років з погляду структури, функціонуючих механізмів та технології преси закінчився - на авансцену історії вийшли нові ЗМІ. 3'явилися способи прискорення зв'язку, телеграф та телефон, друкарські винаходи, необхідні для газетного друку, включаючи фотографію, а також можливості їі публікації й різні процеси друку зображень.

Одночасно із заснуванням європейських радіокомпаній у 1924 р. розпочалися регулярні угорські радіопрограми. Радіо потужно розвивалося в Угорщині. Перші широкомовні передачі почалися в Угорщині навесні 1924 року з Наукового інституту Королівської пошти. Особливий поштовх цьому надав випуск у країні дешевих радіоприймачів. Проблеми з радіопрограмами виникли після гітлерівської окупації Угорщини, але $з$ приходом Радянських військ радіо знову запрацювало в ефірі.

Міжвоєнний період став зародженням угорської журналістики, заснованої на демократичних принципах. Незважаючи на авторитарну владу Хорті, в країні існували газети та журнали різних політичних спрямувань від крайніх правих до крайніх лівих. Цей досвід наслідували в дуже важливий час для угорської державності, після падіння соціалістичного ладу в період - 1989-1990 pр., використовується він і сьогодні, коли в Угорщині панує практично однопартійна влада.

Значення цього другого, міжвоєнного, періоду в тому, що формуються масова преса сучасного типу і принципи взаємин преси, влади і бізнесу. Гострота полеміки на національному рівні в цей час досягла свого піку.

Багато філософських ідей, політичних та громадських концепцій, які виникли в період між 1918 і 1945 рр., знайшли своє друге народження або цікаве переосмислення в сучасному житті угорської преси.

Міжвоєнний період став добою еталонної публіцистики. У цю добу творили безліч талановитих людей, яких хвилювали насамперед проблеми держави і нації, мови і людини. Яскраві голоси угорських публіцистів - Деже Костолані, Ференца Молнара, Ласло Немета, Лайоша Фюлепа й інших були почуті 
всим світом. Тріанонський синдром тяжким вантажем відбився в самосвідомості нації, поставив у епіцентр угорського образу ворога євреїв, масонів, більшовиків і лібералів.

Журналістика у період 1945 - 1956 років. Після закінчення Другої світової війни громадяни Угорщини жили надією на докорінні суспільно-політичні зміни, розраховували вони на свободу та незалежність преси. Після того, як була знищена галаслива й агресивна пропагандистська машина Салаші, потрібно було створювати нову медіаполітику. Дослідники історії преси цього періоду зазначають, що у цій царині на початку панував інформаційний вакуум. Так, наприклад, з 1944 року кількість опублікованих газет була менше десяти.

Ще один головний гравець у системі 3МI - радіо - мовчало місяцями, професійна служба новин, а також іiі флагман - УТА також лежало у руїнах.

Правове середовище, яке регулювало життєдіяльність преси та забезпечувало здійснення свободи думок, знаходилося у руйнації. Старі закони не працювали, а нові ще не були створені.

У 1946 році був прийнятий закон № I «Про державну форму Угорщини» у ньому було зафіксовано, що «одне з «природних $\mathrm{i}$ невідчужуваних» прав громадянина є право на вільне вираження власної думки».

Після прийняття цього закону уряд вжив низку заходів для забезпечення видання періодичних видань, а також щодо впливу на медіасистеми. Нормативно-правова база щодо преси того часу носила досить маргінальний та технічний характер, але головне, що вони не обмежували свободи думок.

У перші роки після звільнення преса Угорщини була дуже різноманітна і неоднорідна, що разюче відображало наявність багатопартійності.

До 1945 року угорський ринок щоденних газет демонстрував надзвичайно багатоманітну картину. Між двома світовими війнами були опубліковані сотні політичних щоденників і щотижневиків, у столиці було видано два десятки часописів.

Радянська армія мала всі ресурси країни для управління пресою. У цей період тільки з дозволу радянської влади можна було друкувати місцеві газети невеликими тиражами. Перша 
така газета угорських комуністів вийшла під назвою Népakarat 15 жовтня 1944 року в Орошазі.

Отже, у цей період масмедіа працювали в основному як газети для коаліційних партій, але кількість членів партії та кількість примірників значно відрізнялися. Формування громадської думки, найважливішим інструментом якої є преса, проходило на тлі боротьби між партіями. У різних статтях та звітах вони сперечалися, критикували один одного, здійснювали партійну пропаганду і мобілізували існуючих симпатиків.

Перші два - два 3 половиною роки епохи коаліції разом із усіма їі темними сторонами були «золотим віком» для угорської преси. 3 приходом до влади комуністів були розігнані партії та ліквідовані різні газети й журнали.

У 1948 році кількість газет скоротилася. Зі 134 органів залишилося тільки 8 провінційних газет та 11 центральних. Сім адміністративних районів отримували лише один тижневик.

Управління повітовими газетами перебрали на себе партійні комітети. Замість закритих щотижневих газет і журналів на початку 50-х років було започатковано набагато менше нових видань, але й ті знаходилися під суворим контролем.

У той же час, наступ на свободу преси супроводжувався значним погіршенням журналістських стандартів. Про це найкраще свідчать дані про освіту кореспондентів. Серед них вищу освіту мали трохи більше $25 \%$. У центральних газетах третина журналістів навіть не мала бакалаврської освіти.

Після націоналізації преси домінували не професійні чи літературні міркування, а ті, що забезпечували потреби тотальної пропаганди. Основна мета полягала не в інформуванні населення, а, маючи монополію на інформацію, надавати через цензуру дозовані новини, а то і поширювати неправдиву інформацію. При цьому влада виходила 3 того, що чим нижчий стандарт на інформацію про суспільне життя, тим простіше керувати та впливати на населення.

Вони також намагалися оволодіти так званою партійною мовою. У газетних статтях комуністичні журналісти використовували слова: «передовиця», «свобода», «демократія», «мир». 3 іншого боку, ворог може бути лише «реакційним», «фашист- 
ським» $\mathrm{i}$ «ворогом народу». В той же час, вони намагалися стерти з суспільної свідомості такі поняття, як Бог, нація, родина, молитва, церква, спасіння, любов до ближнього тощо.

Між 1949 та 1953 роками складалося враження, що журналісти наслідували стиль військових підручників: «виробничий фронт», «виробничі баталії», «сільськогосподарський фронт», «культурний фронт», «робочий фронт», «війна світу». Статті закликали «робітників до штурму». Виробництво було битвою, i будь-які промахи в роботі прирівнювалися до атаки противника.

Матяш Ракоші дав приклад вихваляння Сталіна: «Товариш Сталін - найкращий угорський учитель», «випробуваний», «далекоглядний», «улюблений», «мудрий керівник», «головний архітектор наших будівельних робіт», «улюблений лідер нашої партії», «наш заохочувач», «наш улюблений батько», «коваль нашого успіху», «вогнемет», «блискучий», «упевнений керманич» тощо.

Після смерті Сталіна у 1953 році докорінні трансформації відбулися і в угорському керівництві. Ракоші був замінений прем'єр-міністром Імре Надьом. Однак боротьба за владу ще була не закінчена, тому що Ракоші залишився першим секретарем ЦК партії, а Ерне Гер - найвпливовішим віцепрем'єрміністром, а також Міністром внутрішніх справ. За лаштунками почалася жорстка, відчайдушна політична боротьба між реформатором Імре Надьом і сталіністами, що підтримували Ракоші.

Коли політичне керівництво розкололося на два конкуруючі табори, той самий процес відбувся також серед журналістів. Деякі з них підтримували Імре Надя та його нову політику, але більшість продовжувала наполягати на керівництві Ракоші.

Таким чином, Угорщина підійшла до 1956 року, в якому відбулася Народна революція, у підготовці якої взяли активну участь засоби масової інформації країни. Звертає на себе увагу той факт, що угорські комуністи під керівництвом своїх московських однопартійців своїм недолугим втручанням у суспільнополітичне життя Угорщини наблизили народне повстання. I хоч з допомогою радянських танків вдалося Революцію задушити, 
цей перший у соціалістичному таборі паросток свободи розцвів у кінці 80-х - на початку 90-х років створенням демократичної, правової держави.

Період 1953-1956 рр. характеризує досить потужна діяльність журналістів. Як і будь-яке неординарне історичне явище, угорська революція породила яскраву публіцистику, яка прекрасно передає духовну атмосферу «будапештської осені», виконану одночасно з пафосом і трагізмом. Суттю публіцистики 1956 року, можна сказати, був пафос реформування існуючого ладу, без заперечення при цьому соціалістичної ідеї. Головним рупором була газета Спілки письменників Irodalmi Újság, яка за лічені тижні збільшила тираж 38 до 30 тис. примірників. Значний резонанс викликали також публікації в газетах «Esti Budapest», «Magyar Nemzet», «Szabad Ifjúság», «Hetfői hirláp». У 1956 р. у політичному дискурсі також спливли нові поняття. Так, наприклад, вираз «хомо комінтернікус» вигадав угорський публіцист та історик Арпад Пюнкьошті, який у книзі «Ракоші в боротьбі за владу. 1945-1948» якраз і аналізує діяльність одного з таких запрограмованих у Москві «хомо». У 1956 р. роль письменників у політичному житті також була значною. Невирішена політико-лінгвістична проблема міжвоєнного періоду зі словами «громадянин», «консерватор-народник» і «західникліберал» переживає новий етап у творчості сучасних публіцистів, оскільки місце, яке займала в XIX-XX ст. мова художньої літератури, переходить до публіцистичного стилю, мови ЗМІ. Треба також мати на увазі ситуацію з тим, що в Угорщині (як і в низці інших країн) існує традиція участі письменників у суспільному житті в якості голосу нації, совісті нації і т.ін.; за відсутності розвиненої демократичної системи волевиявлення вони намагалися iї компенсувати, брали на себе занадто багато, виступали від імені народу. В 1956 р. проглядалися явні претензії письменницьких кіл на роль альтернативної політичної сили. В Угорщині XX століття література - більше ніж літератуpa, а публіцист - це письменник, що втручається в політику. А сама політика, як ніколи, проникла в буденне життя людей. Насамперед вона робила це через мову. Політична риторика мови офіційних осіб комуністів пішла, іiі змінила мова інтелектуалів. 
Цей тренд до ускладнення і професіоналізації політичної комунікації не став переважаючим - угорський політичний словник був разом з тим досить спрощений, у процесі експериментів 3 традиційними, іноді й зовсім архаїчними елементами. Зазначимо, що феномен езопової мови набув поширення в Угорщині, як i в усіх країнах, які зазнали впливу соціалізму з його граничним контролем кожної букви. Оточені з усіх боків недоброзичливцями і шпигунами, журналісти й письменники виробили цікаву мову, яку часто в правлячих колах просто не розуміли: читати між рядків не завжди легко. Тому якщо на сторінки періодики проривалося інакомислення, то воно було найкращим, рафінованим. Тут можна говорити і про позитивний вплив тієї малої його частини, що навчила володіти думкою та мовою таких майстрів, як Петер Естергазі, Іштван Ванча, Густав Медьєші, на чиїх творах, у свою чергу, вже виховане не одне покоління. Національна свідомість - система рамок і поступок, що характеризує будь-яку націю, це похідна національного буття, яка, як у дзеркалі, відбилася в статтях публіцистів. У випадку Угорщини - малої нації - вона відіграє ще більш визначальну роль: чим менше дозволеного і прийнятного, тим більш концентроване все практичне життя всередині суспільства. Поряд з подоланням комуністичного минулого і інтеграцією в Свропу, набуттям себе в Європі, головна проблема угорської національної свідомості полягає в тому, як вирішити проблему розбіжності міждержавних і міжетнічних кордонів, враховуючи значущість угорської діаспори в сусідніх країнах і наявність проблем з іiї становищем.

Революція 1956 року постала внаслідок розбіжності прагнень здорових сил Угорщини реформувати сталінську модель державної влади з інтересами СРСР - тоталітарної держави, непридатної до перетворень, що не допускала, щоб країни, які потрапили до іiі зони панування, формували демократичний лад, відмінний від її моделі. Соціальна база й політична палітра Угорської Революції 1956 року давала підстави уряду I. Надя діяти саме у революційний спосіб: повалити сталінську форму правління, відновити повний суверенітет УНР, добитися нейтралітету на зразок Австрії і позбутися залежності від СРСР. Ці 
вимоги мали широку підтримку народних мас Угорщини, вселяли велику надію й серед українства. Революція та національновизвольна війна Угорщини 1956 року - найбільша серед усіх 34 країн комуністичного режиму світу, що змела сталінську модель державного устрою та забезпечила тріумф демократії. У Революції перемогли здорові сили нації. Вона випередила час, але зазнала збройної поразки через радянське втручання, угодницьку політику країн-сателітів Москви.

Провина за поразку угорської праведної справи лежить на СРСР та на бездіяльності західних країн. Жодна з країн світу не підтримала справедливу боротьбу Угорщини. Рішення ООН щодо засудження втручання СРСР у справи суверенної держави та щодо виконання смертних вироків лідера Революції та його соратників були декоративними. Зафіксований переможцями Другої світової війни поділ Свропи не дозволив Угорщині, як й іншим країнам і народам, вирватися зі сфери впливу СРСР та відновити свій суверенітет. Брутальне придушення народного повстання 1956 року і започаткованих реформ в Угорщині значною мірою підірвало авторитет СРСР на міжнародній арені, світові сили консолідувалися у своїх діях проти червоного імперіалізму.

А політико-правові й демократичні перетворення, прискорення економічного розвитку завдяки технологічним революціям у західних країнах виштовхнули соціалістичну систему на чолі з СРСР на узбіччя світового прогресу, оскільки через неспроможність мирно конкурувати вона зазнавала краху. Угорський чинник був вагомим і для піднесення українського національно-визвольного руху. Завдяки сприятливим міжнародним та геополітичним умовам (розпад СРСР і соціалістичної системи, демонтаж комуністичної диктатури) й наполегливій боротьбі країнам Центрально-Східної Свропи та народам пострадянського простору вдалося вибороти незалежність, подолати тоталітаризм і започаткувати формування демократичного устрою.

УСРП, яка на чолі з Яношом Кадаром прийшла до влади в Угорщині у 1956 році й керувала країною до 1990 року, зуміла вивести державу з політичної та економічної кризи, перетвори- 
ти їі в найуспішнішу серед інших членів соціалістичного табору. Звичайно, у цьому угорцям допоміг СРСР, що надавав країні значну економічну та фінансову допомогу. Тільки за рахунок постачання дешевих нафти та газу Угорщина мала зиску 6 мільярдів доларів США щорічно.

Новому керівництву Угорщини після 1956 р. дісталася тяжка спадщина. У суспільно-політичному житті панував страх, апатія та недовіра, в економіці - повна розруха. Під пильним контролем з боку Радянського Союзу Я. Кадар мав знайти ту золоту середину, яка б давала можливість, не викликаючи підозри Москви, провадити таку політику, що максимально відповідала б національним інтересам Угорщини за існуючих умов.

3 січня 1968 р. розпочався процес реформування угорської економіки. Однак, після відомих подій 1968 р. у Чехословаччині впровадження в життя угорських реформ було значно уповільнено, а після 1973 р. практично припинено.

На початку 80-х років угорський соціалізм переживав усі ознаки системної кризи. Керівництво країни, пам'ятаючи події 1956 р., продовжувало політику підтримання високого життєвого рівня за рахунок насамперед іноземних кредитів. Обсяг заборгованості країни за 80-ті роки збільшився вдвічі, іiі сума дорівнювала річному національному доходові країни. На той період Угорщина мала найвищу заборгованість на душу населення серед соціалістичних країн. Усе це призвело до значного дефіциту державного бюджету країни, інфляції, зниження купівельної спроможності населення, зростання безробіття. У суспільстві знову заговорили про кризу довіри до влади. Під тиском обставин УСРП повертається до ідей реформування економіки середини 60-х років.

У політичному житті також розпочалися зміни. На вибори до парламенту було дозволено висувати не одного, а кілька кандидатів. У засобах масової інформації все частіше з'являлися критичні виступи щодо економічної ситуації в країні, про становище угорців за кордоном, переважно у Трансільванії. Як правило, ці виступи залишалися «непоміченими» $з$ боку партійної еліти.

У цьому зв’язку потрібно звернути увагу на таку обставину. 
В угорському «соціалістичному» суспільстві завжди був присутній моральний, а за можливості й реальний спротив радянському диктату. Причому це неприйняття всього радянського не залежало від того, яку посаду людина обіймала в державнопартійній ієрархії. I тому щойно з'явилася невеличка можливість без особливого ризику розпочати опозиційну боротьбу, одразу почали формуватися різноманітні союзи, товариства, громадські організації.

Роль своєрідного каталізатора демократизації суспільства в ті роки активно відігравала Спілка письменників Угорщини. I хоч ЦК УСРП досить жорстко ставився до Спілки (1983 р. відповідні санкції було вжито до редактора журналу «Mozgo Vilag», a 1986 р. - розформовано редакцію літературного журналу «Tiszatai»), письменники не здавалися. У листопаді 1986 p. на загальних зборах Спілки до керівництва організації не було допущено жодного члена УСРП, що практично означало відкриту конфронтацію більшості письменників із владою. У середині 80-х років уже стало зрозуміло, що угорське суспільство готове до найбільш кардинальних змін суспільного ладу. Зупинка була лише за одним - наскільки Москва була готова відпустити Будапешт зі своїх обіймів. Тому прихід до влади в Кремлі М. Горбачова сприйнявся в Угорщині, як і в інших соціалістичних країнах Європи, надто оптимістично. Угорцям у цей момент, саме на цьому відтинку історії, потрібен був такий Генеральний секретар, який скаже: «Йдіть, куди хочете. До Європи - то до Європи, до капіталізму - то до капіталізму абощо». Саме так і сталося. На цьому, практично, завершується третій етап побудови «розвиненого соціалізму» в Угорщині й розпочинається четвертий етап - етап підготовки повалення тоталітарної системи та переходу до суспільства, що засновується на принципах демократії і ринкової економіки, впровадження багатопартійної системи.

Янош Кадар доручив письменникам та журналістам визнати, що 23 жовтня в Угорщині не було революції і закликав їх присвятити всі свої зусилля цьому поясненню для населення. Навіть у режимі Кадара журналісту все ж довелося працювати солдатом партії. Преса залишалася, згідно з ленінськими прин- 
ципами, колективним агітатором, колективним пропагандистом та колективним організатором.

Під час призначення журналістських кадрів усіх рівнів залучали політичну поліцію для перевірки їх надійності. Історія кожного кандидата досконало вивчалася, розпочинаючи від бабусь і дідусів. Попередні професії, місця навчання та роботи, систему стосунків, друзів, родичів, близьких родичів, подружжя, побратимів тощо. Вони вивчали ставлення кандидата до Радянського Союзу, партії, «соціалістичного будівництва», політичних кампаній, віросповідання тощо.

Окрім головного редактора, існувала редакція, яка в часи Кадара приймала дві форми. В одному випадку, редакція складалася 3 керівників, які працювали над газетою чи журналом: заступника головного редактора, редактора випуску, партійного секретаря. В іншому - це були представники спеціальних органів.

У 50-х роках через високу ізоляцію керівництво партії зосередилося майже виключно на внутрішньополітичній журналістиці. Щодо журналістів, які займалися зовнішньою політикою, то вони брали інформацію із зарубіжних інформаційних агентств. У добу Кадара в пресі часто було більше новин про третю світову війну, ніж про Угорщину. У холодній війні через протистояння двох великих держав та військових блоків усе вважалося важливим: В’єтнам, Ангола, Чилі, Нікарагуа тощо були на перших шпальтах провідних газет.

Давалися також інструкції щодо того, яку саме пропаганду слід вести, як викладати певні події, як пояснити проблеми, що не вдалося приховати. Наприклад, економічні труднощі 3 витратами на гонку озброєнь, злочинність, корупцію потрібно пов' язувати з впливом капіталістичного середовища. 3 іншого боку, увагу читачів потрібно було звернути на зростання виробництва та споживання, на безпеку існування в соціалістичних країнах, у тому числі Угорщини.

Преса епохи Кадара показала своєрідне обличчя дволикого Януса. Ідеологічні засади все ще повинні були повторюватися як «молитовний млин». Нудні, заповнені штампованими фразами, святковими реляціями газетні сторінки мали викликати інтерес у читачів. Політична пропаганда все ще ставила Лені- 
на прикладом політичного публіциста: «Стиль, міркування та мобілізація сили ленінської журналістики з тих пір слугували прикладом для всіх комуністичних публіцистів. Ленін завжди знаходив проблему, яка найбільше турбувала робітничий клас у той час, і писав про це. Його статті завжди сперечалися, аргументували, розкривали, вели за собою правильним шляхом».

Щотижневі газети також відігравали значну роль у інформаційному просторі режиму Кадара. Майже кожен соціальний прошарок суспільства мав свою щотижневу газету. Не було лише видання, що стосувалося внутрішньої політики.

При соціалізмі успішність письменників і поетів оцінювалася не ступенем їх таланту, а відповідно до міркувань літературної політики, й від цього залежала кількість примірників книг, у яких друкувалися їх праці.

Розпочинаючи з 1967 року режим Кадара розпочав боротьбу 3 антисоціалістичними елементами, насамперед сконцентрувавши свої зусилля на пресі та літературі. Саме серед журналістів і письменників партія бачила своїх головних ворогів. Використовуючи метод «батога та пряника», партійним функціонерам на певний час вдалося зменшити протистояння $з$ представниками творчої інтелігенції.

Але закрити рота всім не вдавалося. I час від часу в газетах, журналах з'являлися статті, в яких гостро критикувалася соціалістична дійсність, викривалися проблеми повсякденного життя угорського народу, висловлювалася незгода 3 політикою Радянського Союзу. За такі публікації звільняли з роботи головних редакторів, закривали видання.

Тим не менше, партії не вдалося зберегти монополію на правду, і рано чи пізно до пересічного угорця доходила правдива інформація, й урешті-решт народ Угорщини зробив свій вибір наприкінці 80-х років, змінивши політичний режим у країні.

23 жовтня (це дата початку трагічних подій угорської осені 1956 р.) 1989 року в органі уряду - газеті «Мадяр хірлап» - був опублікований текст конституційних поправок, які (за безпосередньої участі Ради міністрів на чолі з Міклошем Неметом) зачіпали 80 відсотків тексту Основного Закону. Таким чином, 
по суті в країні була прийнята тимчасова конституція, що замінила Конституцію 1949 р. Це означало, зазначалося у ЗМI, що закладена законодавча база мирного переходу країни до ринкової економіки, багатопартійної системи, в кінцевому рахунку - до зміни моделі, республіки замість «народної республіки». Фундаментальними принципами державного устрою Угорщини, згідно з тимчасовою конституцією, оголошувалися «громадянська демократія» і «демократичний соціалізм». Також було гарантовано дотримання громадянських свобод та прав людини, принципу багатопартійності, заборони на політичну монополію однопартійної системи. Під тимчасової конституцією затверджувалася необхідність вільного вибору такого уряду, який міг виражати інтереси народу і нести пряму відповідальність перед ним, поряд з введенням принципу поділу влади. Також було скасовано інститут Президії - його замінила президентська адміністрація, яка обирається парламентом. Спікер Державних зборів М. Сюрьош (який незабаром став тимчасовим президентом країни) оголосив про створення Угорської республіки, про що інформувала урядова газета Magyar Hírlap. В Угорській Народній Республіці система державного соціалізму була скасована де-факто і де-юре. Зміна моделі, або революція, сталася зовсім мирно. Але не тихо: ЗМК відіграли в цьому процесі чи не ключову роль. Сама ж Угорщина відіграла роль каталізатора, прискорила розпад усього соціалістичного табору.

Слід зазначити, кажучи про роль ЗМІ у зміні політичної моделі суспільства, що істотну роль, як у зміні режимів в Угорщині та інших країнах народної демократії в Свропі, так і в демонтажі всієї системи соціалізму відіграли процеси перебудови й гласності в Радянському Союзі та діяльність радянських медіа - це був свого роду «сигнал» про те, що час змін настав.

Різноманітні видання, які з'явилися або існували раніше, після 1989 року сформували особливу угорську палітру засобів масової інформації, де знайшлося місце лівим і правим друкованим органам, масовим і якісним виданням, національним i субкультурним газетам та журналам. Як правильно висловився медіадослідник Петер Байомі-Лазар, усі разом угорські ЗМІ 
того часу відбили існуючу тоді демократичну консолідацію політики. Слід також враховувати, що для такої невеликої країни, як Угорщина, кількість журналів, які відверто виступали за зміну існуючого ладу, була досить значною.

Різка зміна ідеологічної, культурної, моральної парадигми угорського суспільства в кінці 80-х - початку 90-х рр. ХХ ст. поставила перед публіцистикою важливе завдання - утвердити в суспільній свідомості нові ідеї і нові орієнтири. Причому, в силу обставин, що склалися, й традиційного розколу угорського суспільства на лібералів і консерваторів, ця задача вирішувалася в лівій та правій пресі по-різному. Як відомо, жодне суспільство не обходиться без ідеології, публіцистика є провідником ідеології в маси, тому лінгвістика «переконання» стає невід'ємною рисою публіцистичного дискурсу, найбільш помітною і затребуваною в епоху змін.

Окремим розділом у монографії розглядається медіаправо в Угорщині на сучасному етапі. Критична маса інформації, знань, нормативно-правових актів дозволяє висловити позицію про формування в праві такого феномену, що можна умовно визначити як медіаправо, дослідження юридичного забезпечення діяльності засобів масової інформації (далі - ЗМІ). Актуальність проблематики щодо медіаправа має важливе значення як для правотворчості, так і для правозастосування, а також для правової освіти та юридичної науки (зокрема, для розвитку теорії інформаційного права).

Після зміни режиму, яка відбулася в Угорщині у 1990 році, у країні діяв Закон про пресу, що був прийнятий у 1986 році. Державні збори країни внесли до нього поправки в січні 1990 року. Однак, вони стосувалися лише друкованої преси та не торкалися електронних 3МI.

У подальшому уряд Й. Анталла робив неодноразові спроби внести у Державні збори проєкт Закону про 3МI, але кожного разу ці зусилля провалювалися через рішучий супротив опозиції.

Почався процес, який повториться під час наступних змін уряду, нові керманичі, що прийшли до влади, замінили всі керівні кадри провідних 3MI, а на їх місце були призначені нові люди з новим баченням діяльності масмедіа. 
У 1996 році таки був прийнятий Закон про засоби масової інформації, що набув чинності 1 лютого цього року. Підготовку Закону здійснювали Міністерство юстиції і Міністерство культури та народної освіти, його обговорювали Погоджувальна рада коаліції, опозиційні й урядові партії, комітет з культури Державних зборів, державні секретарі відповідних міністерств та відомств на своїх засіданнях, а потім і уряд. 21 грудня 1995 року парламент прийняв Закон про ЗМІ з підтримкою на 90\%, не голосувала тільки фракція партії дрібних власників. 1996/1 Закон набрав чинності 1 січня 1996 року.

У Законі про ЗМІ Державні збори визначили основні принципи та правила мовлення. У межах цього було встановлено процедурні правила отримання прав на мовлення й визначено організаційні засади суспільних мовників. Одним 3 найважливіших положень Закону є створення Національної ради з питань телебачення і радіо (НРТР) та її Комітету зі скарг.

3 прийняттям Закону можна говорити про трансформацію інституційної системи у функціонуванні радіо і телебачення в Угорщині. Найважливішим елементом Закону є те, що базова структура діяльності цих 3МI, яка була введена в більшості європейських країн, упроваджена і в Угорщині: нею було започатковано, поряд із державними, комерційні радіо та телебачення. Таким чином, з позиції професійних, юридичних і фінансових принципів програми суспільного мовлення, як постачальник загальнодоступних послуг, можуть бути у приватній власності. У той же час, засоби масової інформації, що знаходяться в державній власності - Угорське радіо і телебачення, Дунайське телебачення - не могли мати комерційні канали.

У Законі про ЗМІ говориться, що одним з основних принципів $\epsilon$ те, що мовлення в Угорській Республіці є безкоштовним. Мовник самостійно визначає зміст мовлення й несе за нього відповідальність. Однак, мовник повинен поважати конституційний порядок, його діяльність не повинна порушувати права людини, і він не мусить розпалювати ненависть стосовно людей, народів, націй, національних, етнічних, мовних та інших меншин або проти будь-якої церкви чи релігійної групи. Мовлення не може бути направлене на явне або приховане пору- 
шення прав будь-якої меншини чи більшості, що грунтується на расистській ідеології.

У Законі сформульовано в якості одного 3 найважливіших принципів інформування те, що інформація про внутрішні та зарубіжні події і спірні питання, які становлять суспільний інтерес, повинна бути універсальною, фактичною, своєчасною, об'єктивною та збалансованою. Усі матеріали, які готуються до ефіру, за змістом і жанром не повинні віддзеркалювати погляди певної партії або політичного руху.

Прийнятий у 1996 році Закон проіснував 14 років. За цей час в Угорщині змінилося кілька урядів: соціалісти на чолі 3 Дьюлою Хорном; перший кабінет Віктора Орбана; потім два цикли правління соціалістів, які очолювалися Петером Медеші, Ференцом Дюрчані та Гордоном Байнаї. Закон про ЗМІ був так розроблений, що витримав усі спроби його змінити. Найголовніші питання, закладені в ньому, не можна було змінити простою більшістю. Було потрібне досягнення компромісу, передусім з опозицією. Критиці насамперед піддавалося положення про незалежність ЗМІ від політичних партій. Насправді правлячі партії користувалися своєю владою для того, щоб використовувати незалежні медіа в своїх цілях.

У результаті впровадження Закону в Угорщині склалася подвійна система 3МI. 3 одного боку, в деяких медіа-установах політичні інтереси брали гору над професійними аспектами та правдивим відображенням тих чи тих подій. 3 іншого - 3MI, що займалися суспільним життям і політичними подіями, стали заідеологізованими. У руках партій були зосереджені газети, радіо, телебачення. Масмедіа стали ареною виступів політиків, значно зросла їх роль у боротьбі за владу.

Виявилося, що Закон про ЗМІ не призвів до більш вільної, незалежної преси, оскільки вона стала полем для політичних ігор. Уряди змінювалися, але масмедіа, які Законом гарантувалася як незалежні, ставали частиною політичної здобичі чергового керівництва країни.

Позитивним результатом у медіасфері $є$ те, що в Угорщині склалася дуальна система 3МІ внаслідок набуття чинності Закону про 3МI. 
В установах, які керували ЗМI, професійні міркування часто замінювалися політичними інтересами, саме так приймалися рішення щодо стратегії медіа.

Зменшилася важливість засобів масової інформації, що належать до державних та громадських служб, національні комерційні телебачення охопили більшість глядачів. Комерційні канали стали більш конкурентоспроможними порівняно $з$ суспільним телебаченням. Ці програми значно трансформували ринок телебачення.

Підсумковий висновок епохи про те, що медіаконтент значно збільшився, став набагато демократичнішим, оскільки Інтернет став усюдисущим, ніж будь-коли раніше.

18 квітня 2011 року Державні збори Угорщини прийняли нову Конституцію - Основний Закон країни, яка набрала чинності 1 січня 2012 року. В цьому документі спеціальним параграфом 61 було визначено основоположні принципи діяльності 3МI. 22 липня 2010 року Державні збори прийняли Закон, що регулює засоби масової інформації та комунікації, згідно з яким Національне радіо й телебачення і Національний орган зв'язку були перетворені у Національне відомство засобів масової інформації та комунікацій (НВЗМІК). НВЗМІК є автономним органом державного управління, який бере участь у керуванні сферою комунікацій і здійсненні державної політики у цій царині. Цей орган обирається Державними зборами, він $є$ автономним, з незалежною правосуб'єктністю. Ця організація руйнує інформаційні монополії, захищає незалежність мовників та гарантує свободу вираження поглядів, контролює самостійність преси на основі конституційних принципів і повідомляє про цю діяльність Державні збори.

11 червня 2010 року депутати Державних зборів Андраш Чер-Палковіч та Антал Роган подали до парламенту проєкт Закону про свободу преси та захист медіаконтенту, який отримав назву медіаконституція. Закон був прийнятий парламентом 2 листопада 2010 року та замінив Закон про пресу, який діяв з 1986 року [5]. Він визначив, що означає медіаслужба, як здійснюється відстеження та пошук медіасервісів, як діє лінійний аудіальний медіасервіс, що таке медіаконтент та контент- 
провайдер. Це законодавство поширилося на весь медіаконтент, у тому числі й на Інтернет.

Ці два Закони, про які йшла мова вище, викликали різку критику в Свропейському Союзі, всі великі європейські періодичні видання вкрай суворо висловилися про них, вживаючи серед інших і такі визначення, як «шовіністичний». 3 моменту прийняття Закону своє занепокоєння висловили всі найбільші міжнародні інститути - ООН, Рада Свропи, ОБСС. Ці нові Закони, які набули чинності 1 січня 2011 року, призвели до повного контролю ЗМІ Угорщини з боку уряду, а це, у свою чергу, підриває демократичні цінності та авторитет Свросоюзу.

Не випадково Прем'єр-міністр Угорщини Віктор Орбан приділив таку увагу контролю за засобами інформації, оскільки вони і надалі визначають політичне життя країни й завжди чітко виявляють свою позицію стосовно правлячого режиму. Політичні сили, які приходили до влади в країні, завжди намагалися використовувати в своїх інтересах цей вплив друку і публіцистики зокрема. В Угорщині періодика в досить великій мірі визначає свідомість інтелігенції та й значної частини населення.

Після приходу до влади партії Фідес - УГП 29 травня 2010 року Прем’єр-міністром Угорщини стає знову В. Орбан. Виконавча, законодавча і судова влада Угорщини поступово зміцнювали зв'язки між собою та правлячою політичною силою, керованою Віктором Орбаном. Тепер ці гілки влади, які повинні бути незалежними, підтримують один одного і Фідес - іноді ненав'язливо, а іноді відкрито.

У 7 розділі було детально проаналізовано 61 параграф нової Конституції Угорщини, що набрала чинності 1 січня 2012 року, в якому було визначено основоположні принципи діяльності 3МІ. Також було досліджено прийняті 22 липня 2010 року Закон, що регулює засоби масової інформації та комунікації, і 2 листопада 2010 року Закон про свободу преси та захист медіаконтенту, який отримав назву медіаконституція. Ці нормативноправові документи повністю змінили медіапростір і значно посилили контроль держави за 3МІ.

У той же час «Фідес» не використовує характерних для будь-якого авторитарного режиму засобів масштабної адміні- 
стративної цензури, як і не застосовує прийнятного у м'яких диктатурах - ручного режиму управління за принципом «підтримуємо - терпимо - забороняємо». Цей принцип працював тільки в умовах панування державної власності. У той час поза колом державної власності перебували лише переслідувані владою самвидави демократичної опозиції, публікації яких безпосередньо доходили до декількох тисяч осіб. Після зміни режиму в сфері медіа виникла структура змішаної власності, яка нині контролюється партією «Фідес» за допомогою різноманітних репресивних засобів.

3МI, що знаходяться у власності держави, були поставлені під керівництво партії шляхом прямого застосування владних засобів (призначення комісарів, прямі директиви, цензура). Великі телеканали (RTL Klub, TV2) були деполітизовані (погрозами застосування санкцій, податком на рекламу). Критично налаштовані 3МІ заганялися в «гетто» (третирування з боку влади, відлякування рекламодавців). Тим часом, політична сім'я 3 допомогою державної підтримки та нелегітимного примусу створила власну медіа-імперію з приватних 3МI.

Новий режим здійснив одержавлення некомерційних 3МI та Угорського телеграфного агентства (УТА), не тільки заволодівши правами власності, а й контролюючи створюваний контент. Їхнє майно і співробітники були переведені у фонд при Раді у справах 3MI, була встановлена сувора цензура, й після загальної чистки одержавлених 3МІ в них прийшли віддані режиму кадри, причому іноді допускалися навіть співробітники праворадикальних ЗМІ. За допомогою безкоштовних державних інформаційних послуг був підірваний, практично ліквідований ринок незалежних інформаційних агентств, таким чином держава побічно впливає на зміст інформаційних програм приватних ЗМI.

«Фідес» підтримує лояльні ЗМІ передплатою і рекламними замовленнями державних та муніципальних установ і фірм. У той же час, партія обмежує свободу друку, мінімалізує доходи приватних медіа, побічно контролюючи їх за допомогою позбавлення державної реклами, залякування й «відмов» приватних рекламодавців. Тим самим вони домагаються розорен- 
ня 3МI, які допускають критику уряду, або принаймні їх відтискування в «резервацію» 3 невеликою аудиторією. Такими, на перший погляд, економічними засобами вдається усувати 3 ринку непокірні 3МI, якщо немає змоги зробити це по-іншому, наприклад, за допомогою прямого адміністративного примусу. Одночасно це деполітизує і найбільші приватні 3MI, змушуючи вдаватися до самоцензури.

Тим часом уряд, підкоряючись своїм інстинктам, за допомогою розподілу ефірних діапазонів грубо ліквідував критичні 3МІ або, влаштовуючи виставу для зовнішніх спостерігачів, замкнув їх у гетто вузької аудиторії споживачів-інтелектуалів. Можливо, інтенсивне спілкування у невеликих співтовариствах політично незалежного Інтернету, Facebook'a створює помилкове враження, що незадоволених урядом багато, але насправді обмін думками ведуть одні й ті ж люди і в одних і тих же співтовариствах.

Нова перемога «Фідес» на виборах 2014 р. забезпечувала партії збереження необмеженої влади. Віктор Орбан, як про це вже говорилося вище, отримав можливість ліквідувати дуалістичний характер керівництва владою і зробити експліцитно свою роль єдиного лідера.

Створення в жовтні 2014 р. Національного комунікаційного управління (НКУ) означало централізацію в двох напрямках. 3 одного боку, управління в обов'язковому порядку об'єднало та монополізувало комунікаційні завдання всіх державних і урядових органів, а також фірм, які частково або повністю належать державі. 3 іншого боку, воно стало займатися пов'язаними 3 цими завданнями: ринковими угодами й замовленнями. Тим самим, унеможливлюючи роботу автономних ринкових механізмів, воно, в той же час, «одержавлювало» все своє оточення і знищувало можливість без того рідкісних сепаратних операцій усередині владних структур. Ця установа прагне не тільки в широкому сенсі визначати суть комунікації державних установ та фірм, а й керувати іiї процесом, а також одноосібно приймати рішення про пільги різним гравцям медіасфери, якою нездійсненною не здавалася ця задача. Завдяки цьому йому практично вдалося вивести $з$ гри кілька пов'язаних з владою, насамперед 
3 Лайошем Шімічкою, медіа-агентств, за допомогою яких державна реклама розподілялася між різними, в тому числі недержавними, друкованими органами.

Суть змін у порівнянні з попереднім урядовим циклом у тому, що ті 3MI, які належать державі, перетворені в медіа 3 необмеженим бюджетом, вони здійснюють демпінг медійних послуг та прагнуть охопити всі жанри і вікові групи аудиторії й керовані безпосередньо, без всяких проміжних інстанцій. Великі комерційні телеканали купуються (TV2) або ж робляться спроби витіснити їх з ринку за допомогою державного примуcy (RTL Klub). У той же час, влада скасувала власну приватну медіа-імперію, і колективне сімейне керівництво змінилося безпосереднім одноосібним керівництвом Орбана.

Уряд Орбана у своєму прагненні захопити медіаринок пішов далі, було отримано право власності на некомерційні 3МІ й Угорське телеграфне агентство (УТА), що уможливило контроль над створюваним ними контентом. Відповідно, вся їх власність, журналістські кадри були передані у Фонд при Раді у справах 3MI, був запроваджений жорсткий контроль влади за змістом і розповсюдженням інформації, друкованої продукції, 3 цих медійних інституцій були звільнені небажані журналісти, їм на зміну прийшли вірні Фідес кадри, й навіть такі, які поділяли праворадикальні погляди. Уряд запровадив безоплатні державні інформаційні послуги, таким чином було нанесено нищівного удару по ринку вільних інформаційних агентств, що дало можливість владі опосередковано регулювати зміст інформаційних конвентів приватних 3МI.

Урядова коаліція знайшла ще один спосіб впливати на 3MI, так, видання, лояльні до влади, отримують від державних і муніципальних закладів рекламні замовлення. У той же час, ті медіа, які критикують уряд, автоматично потрапляють у немилість, їх позбавляють державної реклами, доходить навіть до того, що здійснюється тиск на приватних рекламодавців 3 тим, щоб вони не співпрацювали з цими 3МI.

Таким чином, Фідес карає своїх опонентів, добиваючись їхнього банкрутства або позбавлення їх читацької аудиторії. Якщо ці економічні методи не допомагають витіснити 3 меді- 
аринку непокірні 3МI, в хід іде адміністративний примус. У свою чергу, найбільші приватні 3МI, розуміючи всю небезпеку інформаційного протистояння владі, змушені вдаватися до самоцензури.

Таким чином, напередодні чергових виборів у квітні 2018 р. Орбан створив комплексну систему 3MI, яка успішно діяла по всій країні, забезпечуючи Фідес електоральну підтримку. Паралельно з цим влада проводила постійну боротьбу з опозиційними масмедіа.

Минула виборча кампанія в Угорщині остаточно розколола і суспільство, і медіаспільноту - хто за владу, а хто проти. Про 3МІ вже не говорять як про незалежні чи об'єктивні, а лише як про ліберальні чи консервативні, опозиційні чи провладні, партійні або комерційні.

Незалежні та об'єктивні 3МI не потрібні Угорщині Віктора Орбана. Та й журналісти з більшості угорських 3МI не хочуть бути об'єктивними та незалежними. Вони прагнуть захищати свою країну від ворогів разом із Віктором Орбаном. Такий вектор розвитку угорський Прем’єр назвав неліберальною демократією.

Тому Віктор Орбан без зайвих докорів сумління продовжує монополізувати угорські медіа та розбудовувати в Угорщині «неліберальну демократію», в якій 3МІ - це передовсім вартові режиму, а не його контролери й критики.

Ось у цьому є квінтесенція медіаполітики за часів урядування Фідес - УГС в Угорщині. Прем'єр-міністр Угорщини Віктор Орбан значну увагу приділяв і приділяє контролю за засобами масової інформації, оскільки вони займають визначальне місце у політичному житті країни. У кого в руках масмедіа, у того в руках і влада. Тому за десять років перебування при владі Орбан створив свою медіа-імперію, до керування якої він не допускає навіть своє близьке оточення. Зрозуміло, що це не тільки засіб пропаганди, але і джерело значних прибутків. Тому який би внутрішній чи зовнішній тиск не здійснювався на В. Орбана 3 приводу його медіаполітики, він не піде ні на який компроміс у цьому питанні й буде проводити свою лінію до тих пір, поки буде знаходитися при владі. 
В умовах прогресуючої глобалізації, в метушні швидко мінливих справ і подій людство не помітило істотне явище - зародження в середині 80-х pp. XX ст. нового виду ЗМІ. Не нового типу видання або радіотелепрограми, а саме виду засобів масової інформації! Їх утвердження в системі ЗМІ варто вважати: 1985 року - для США, грудень 1992 року - для України, коли мережеві ЗМІ стали звичайним явищем.

Протягом декількох років система мережевих ЗМІ в типологічному відношенні стабілізувалася. Здавалося, нових змін, у всякому разі функціонального характеру, не передбачається. Однак, вони відбулися: через 15 років, приблизно до 2000-2001 pp. появою в мережі радіо і телебачення. Ще незадовго до цього важко було таке уявити, однак різкий прорив у сфері високих технологій дозволив цьому здійснитися, що призвело до так званої мультимедійної революції. Цифрові технології не просто дозволили створити більш якісний контент, вони створили для ЗМІ нове медіасередовище. Уперше виявилося, що цикл замкнувся - всі засоби масової інформації опинилися в Інтернеті! Й представлені у вигляді онлайн-версій, і чисто мережеві. Знову виникло відчуття, що інтернет-журналістика - це лише форма подання інформації, яка не впливає на сутність змісту. Однак це, безумовно, не так: способи передачі, форми втілення та сприйняття інформації в мережі інші - й у психологічному, і в лінгвістичному, і в соціальному сенсах. Тим не менш, виникло враження стабілізації після 15 років існування електронних мережевих 3МI.

П'ятиріччя 2001-2005 рр. внесло суттєві зміни в глобальну систему WWW. Тоді ж, у 2000-2001 рр. почалися пошуки нових шляхів розвитку Інтернету, а точніше - його нової бізнесмоделі. Утім, тоді ж і незадовго до цього вже були створені нові сервіси, значущість яких у той час ніхто ще передбачити не міг.

У 1996 р. двоє аспірантів Стенфордського університету Ларpi Пейдж (Larry Page) i Сергій Брін (Sergey Brin) заснували компанію, названу ними Google. Своїм завданням вони поставили розробку ефективної технології пошуку інформації на підставі аналізу «зворотних посилань» (back links), що ведуть на даний сайт. 
У серпні 1999 р. у Сан-Франциско був створений портал Blogger - перший простий безкоштовний загальнодоступний сайт, на якому кожен користувач міг розмістити інформацію про себе.

У березні 2000 року в Лондоні кілька ентузіастів створили безкоштовний енциклопедичний мережевий проєкт під назвою «Нупедія» (Nupedia), відкривши однойменний портал. Розвиток цього проєкту знайшов відображення в здійсненні більш масштабної ідеї - створення безкоштовної, яка претендує на всеосяжність, всесвітньої енциклопедії, створеної ентузіастами на добровільних засадах. Новий проєкт, що отримав назву Вiкіпедії (Wikipedia), був офіційно відкритий 15 січня 2001 p.

У 2001 р. співробітники різних інтернет-компаній Кріс ДеВульф і Том Андерсон, маючи досвід роботи з різними сервісами, об'єднали зусилля для створення нового багатоцільового проєкту, який до середини 2003 року вилився у створення спільної компанії MySpace та відкриття однойменного сайту MySpace.com. Ідея проєкту полягала в об'єднанні численних сервісів у одному місці й, відповідно, можливості надання користувачам багатьох послуг одночасно.

Нова людина. Очевидно, що високі технології - це не просто вдосконалення техніки, прискорення процесів отримання й пошуку інформації, вони впливають на саму людину, змінюючи iii. Даючи значні можливості, технологія завжди щось забирала, звужуючи ії творчий потенціал. Так, друковані ЗМІ звузили систему сприйняття світу людиною, надаючи інформацію, оброблену автором, редактором, видавцем. Аудіовізуальні ЗМІ в готовому вигляді надали звукове та відеозображення, нав'язуючи людині образи навколишньої дійсності. Мережеві пішли далі: вони дають готові форми на все, що коли б людині не знадобилося, тексти забезпечені ілюстраціями, професійно підготовлені на всі випадки життя - словники та енциклопедії, газети і журнали, курсові та дипломні роботи, реферати для студентів, дисертації, книги й ін.

Тепер перейдемо до розгляду сучасного стану електронних засобів масової інформації в Угорщині. Розпочнем з радіо. У попередніх розділах ми детально вже писали про цей угорський медіаресурс, його історію та розвиток. 
31 липня 2015 року Угорське радіо, а також три інші громадські мовники, які були під керівництвом MTVA об'єднані в єдину організацію під назвою Duna Médiaszolgáltató. Вона $\epsilon$ правонаступником Угорського радіо та активним членом Свропейської мовної спілки.

Внутрішні мережі з штаб-квартирою в Будапешті й кількома регіональними відділеннями по всій країні, MR відповідає за суспільне мовлення на всій території Угорської Республіки. А також підтримує дев'ять регіональних студій, корпорація виробляє три загальнонаціональних угорськомовних радіоканали (Kosút, Petőfi, i Bártok), що охоплює весь спектр надання радіо громадського обслуговування, а четвертий канал (MR4) спрямований на національні меншини країни.

1 травня 1957 р. під час святкування Дня весни і праці в Угорщині почалося регулярне телемовлення. 2 липня 1957 p. вийшов перший випуск новин - телепрограма «Híradó» - новини. 18 серпня разом з Угорським радіо відбулося об'єднання Угорського телебачення в корпорацію «Угорське радіотелебачення» (Magyar Rádió és Televízió, MRT). На його основі з'явилася Міжнародна організація радіомовлення і телебачення, більш відома як «Інтербачення» (в його структуру першими ввійшли ЧССР, НДР, Угорщина і Польща).

Перехід на кольорове телемовлення завершився в 1971 році, в тому ж році почалися тестові трансляції Другого каналу Угорського телебачення. Ця декада стала найпродуктивнішою в історії угорського телебачення, оскільки загальний обсяг телемовлення становив тисячі годин. 12 травня 1974 року Угорське радіо й Угорське телебачення були об'єднані в Державний комітет з телебачення і радіомовлення (Állami Rádió és Televízió Bizottság).

1 липня 2015 року MTV, MR, Duna Televízió та Угорське телеграфне агентство були об'єднані в Duna Média (повна назва - Duna Médiaszolgáltató - «Дунайська медіаслужба»).

В Угорщині на сьогоднішній день працюють 13 каналів, які транслюються через супутникове телебачення FTA, а також існує розгалужена систем кабельного мовлення. Серед них: загальні й розваги - 19, новини і політика - 4, спорт - 13, доку- 
ментальні - 30, музика - 15, дитячі - 10, кіно - 25, HD TV - 50, регіональні - 9, для дорослих -1 .

Таким чином, в Угорщині створена і функціонує потужна система телебачення, провідні телеканали контролюються урядом В. Орбана, є, щоправда, й опозиційні канали, але їх обмаль, і вони не в змозі конкурувати з потужною системою державних електронних $3 \mathrm{MI}$.

На серпень 2020 року Угорщина у галузі інтернет-інфраструктури займає лідируючі позиції в ЄС, а за використанням Інтернет-сервісів знаходиться в середині серед країн спільноти. У рамках мережевого стовпа DESI Угорщина в 2020 році опинилася на 7-му місці, що на дев'ять місць краще, ніж у 2019 році, й сприятливішому, ніж середній рейтинг конкурентів у Вишеградській групі. У готовності 5G Угорщина має третю позицію в Інтернеті зі швидкістю завантаження не менше 100 мегабіт у секунду.

Серед країн-членів ЄС Угорщина посідає 14-е місце за рівнем використання Інтернет-послуг, просунувшись на 5 місць порівняно з 2019 роком. Перше місце Угорщина займає у використанні соціальних медіа (86 відсотків населення - користувачі).

Частка угорців, які використовують Інтернет-дзвінки, зросла, внаслідок чого Угорщина посіла 3 місце серед країн-членів ЄС у рейтингу 2020 року. В плані корпоративної інтеграції цифрових технологій, розвитку електронного уряду та цифрових навичок робочої сили Угорщина відстає від середнього значення для СС. У корпоративному інтеграційному рівні цифрових технологій Угорщина посідає 26-е місце, відстаючи від минулого року на два місця. Угорщина просунулася на два місця порівняно з 2019 роком, все одно на 24-му місці в рейтингу.

Платформи соціальних медіа мають найбільше користувачів у країні у 2019 році. Серед них найбільш популярні: Facebook, Messenger, Instagram, Linkedin, Pinterest, Twitter.

На ринку угорських Інтернет-новинних порталів представлені: Index, NCore, Freemail - Freemail, Origo, Blog, Hasznaltauto, Jofogas, HVG, Sports747, Hir24.

Підбиваючи підсумок сучасного стану електронних засобів 
масової інформації в Угорщині, потрібно зазначити, що країна у цьому сегменті масмедіа досягла за останні роки значних успіхів. Свій подальший розвиток отримали радіо та телебачення. Потужно ввірвався у медіапростір Інтернет. Усі провідні світові Інтернет-платформи соціальних медіа присутні в Угорщині. У країні також створено мережу угорських Інтернет-новинних порталів. У той же час, і в онлайн-середовищі зберігається тенденція активного втручання уряду Орбана та його оточення в контроль і управління електронними 3МІ. Практично всі головні угорські Інтернет-новинні портали контролюються владою, а ті, що знаходяться в опозиції, мають незначний ресурс і невелику аудиторію. Ця ситуація викликає гостру критику як усередині країни, так і за їі кордонами. Однак Орбан робить вигляд, що це його не обходить і що це внутрішні справи країни. Зрозуміло тільки одне, доки Фідес буде при владі, доти його політика щодо масмедіа буде незмінною. Орбан чудово розуміє: у кого в руках засоби масової інформації - у того в руках і влада, а владу в найближчі 10 років він нікому віддавати не хоче.

Насамкінець спробуємо проаналізувати, як масмедіа Угорщини висвітлюють проблеми в українсько-угорських відносинах, пов'язані з використанням угорської мови в освіті та повсякденному житті національної меншини.

Починаючи з 1990 року, всі уряди Угорщини у зовнішньополітичній діяльності визначали такі пріоритети: інтеграція до європейських та євроатлантичних структур, розвиток добрих відносин із сусідніми державами й захист прав національних меншин, що проживають за кордоном.

Останній напрям зовнішньої політики пов'язаний з так званим «посттріанонським синдромом», який уже протягом сторіччя присутній у суспільному житті Угорщини. Тріанонський мирний договір був підписаний 4 червня 1920 р. у Великому Тріанонському палаці Версаля між Угорщиною, з одного боку, i союзними державами Антанти - 3 іншого.

Договором передбачалися умови, за якими Угорщина втратила 2/3 своєї території з населенням до 3 млн своїх громадян, вихід до моря і флоту, 88\% лісових ресурсів, 83\% виробництва чавуну й 67\% банківсько-кредитної системи і відповідної кіль- 
кості культурних ресурсів. Її територіальні втрати були найбільшими у порівнянні з іншими переможеними країнами Четверного союзу.

До Румунії відійшли Трансільванія і східна частина Банату; до Югославії - Хорватія, Бачка і західна частина Банату; до Чехословаччини - Словаччина і Закарпатська Україна.

10 лютого 1947 року в Парижі союзниками по антигітлерівській коаліції підписано договір з Італією, Болгарією, Угорщиною, Румунією і Фінляндією, котрі були змушені змиритися 3 втратою територій і необхідністю виплачувати репарації, що дозволило їм повернути собі права суверенних держав. Згідно $з$ цими угодами Угорщина була відновлена в межах 1937 р. Для Угорщини це означало, що кордони з сусідніми країнами, закріплені Тріанонським мирним договором, залишаються незмінними з тією різницею, що Закарпаття, яке належало Чехословаччині, стало частиною СРСР, а саме УРСР.

Так, сьогодні приблизно 3 млн угорців проживають за межами країни, з них: в Австрії - 25 тис. 884 ос., Румунії - 1 млн 639 тис., у Чехії - 20 тис. ос., у Словаччині - 520 тис. ос., У Сербській Воєводині - 350 тис. ос., в Україні - 151,5 тис. ос., У Словенії - 6 тис. 243 ос., у Хорватії - 14 тис. 047 ос.

Ця проблема $\epsilon$ і сьогодні досить чутливою для угорського суспільства, угорського політикуму. Тому серед населення досить поширені настрої образи за втрачені території та своїх співвітчизників, котрі не за своєю волею стали громадянами сусідніх держав. Ситуація, яка склалася у цій царині, породила за сто років іiі існування надзвичайно складний комплекс морально-психологічних, етнокультурних, соціально-економічних, а отже, й суспільно-політичних проблем.

Тому цю проблему активно використовують у своїй риториці провідні угорські партії. I не дивно, що парламентська коаліція ФІДЕС - Угорський громадянський союз - Християнська демократична народна партія досить активно здійснює цю політику.

На сьогоднішній день правовою базою співробітництва в питаннях, які стосуються української національної меншини, $є$ міждержавні, міжурядові та міжвідомчі двосторонні документи, укладені Україною з Угорською Республікою. 
Таким чином, можна стверджувати, що в українсько-угорських стосунках створені всі політично-правові умови для того, щоб національні меншини обох країн відчували себе захищеними та, з одного боку, мали тісні стосунки з материнською нацією, з іншого - були забезпеченими в країні проживання всіма можливостями для розвитку культурних, освітніх та національних потреб нацменшин. Але для цього і Україна, і Угорщина повинні чітко виконувати взяті на себе зобов'язання у цій царині.

У грудні 1991 року Прем'єр-міністр Угорщини Йожеф Анталл і Президент України Леонід Кравчук підписали у Києві Договір про основи добросусідства та співробітництва між Угорською Республікою та Україною. Це був фундаментальний документ, що визначив найважливіші зобов'язання обох сторін: відсутність територіальних претензій між двома країнами і гарантії захисту прав меншин, у тому числі в сфері освіти.

В Україні забезпечення прав і свобод національних та етнічних меншин гарантовані Конституцією. Так згідно зі статтею 11 «Етнонаціональну структуру українського суспільства становлять українська нація, корінні народи й національні меншини» [7]. Визнавши корінні народи та національні меншини окремими суб'єктами політико-правових відносин, Конституція поклала на державу обов'язок сприяти розвиткові їхньої етнічної, культурної, мовної і релігійної самобутності.

25 червня 1992 року Верховна Рада України ухвалила Закон »Про національні меншини в Україні», згідно з яким Україна гарантує громадянам республіки незалежно від їх національного походження рівні політичні, соціальні, економічні та культурні права і свободи, підтримує розвиток національної самосвідомості й самовиявлення.

Окремі аспекти захисту прав національних меншин регулюються Законами України «Про мови в Українській РСР», »Про освіту», «Про друковані засоби масової інформації в Україні», «Про свободу совісті та релігійні організації», «Про місцеве самоврядування в Україні».

Але, на жаль, усі ці нормативно-правові документи не беруться до уваги можновладцями, коли мова заходить про політичні інтереси. Петро Порошенко йшов на президентські вибо- 
ри 2018 року з лозунгом «Армія. Мова. Віра». Головним чином, набір цих трьох компонентів був направлений на електорат Західної України, оскільки в інших частинах країни п'ятий Президент підтримки не мав. Зупинимося тільки на мові. Ідеологам виборчої кампанії було вкрай необхідно продемонструвати радикально налаштованій частині виборців, що влада готова змусити говорити українською всіх громадян України. Для цього був прийнятий Верховною Радою 5 вересня 2017 року Закон «Про освіту», стаття 7 якого говорить про те, що особам, які належать до національних меншин України, гарантується право на навчання в комунальних закладах освіти для здобуття дошкільної та початкової освіти, поряд із державною мовою, мовою відповідної національної меншини. Це право реалізується шляхом створення відповідно до законодавства окремих класів (груп) з навчанням мовою відповідної національної меншини поряд із державною мовою і не поширюється на класи (групи) 3 навчанням українською мовою.

Угорські урядовці та політики оцінили ці нововведення української влади як спробу асиміляції угорської національної меншини, позбавлення прав вільно володіти рідною мовою. У свою чергу, Міністр закордонних справ та зовнішньої торгівлі Угорщини П. Сіярто заявив, що його країна блокуватиме всі кроки в напрямку євроінтеграції України в рамках програми «Східного партнерства» та прагнення Києва до членства в НАТО. Подальші кроки угорських високопосадовців стосовно України показали, що ці слова не були пустими погрозами.

Зразу після прийняття Закону в угорських 3МІ розвернулася потужна кампанія критики саме 7 статті цього документа. Тільки за місяць було надруковано 136 статей на цю тему.

3 ухваленням нового Закону про освіту добросусідські стосунки з Угорщиною закінчилися, хоч Будапешт був палким прихильником інтеграції України в СС та НАТО. Угорці підтримали угоду про відмову від віз між СС і Україною, одними з перших ратифікували Угоду про асоціацію Україна - СС.

Прийнятий Закон також суперечить європейським цінностям, міжнародним зобов'язанням України, Угоді про асоціацію між Україною та СС, Плану підготовки України до НАТО та 
двостороннім угодам. Перелічені угоди стверджують, що попередньо набуті права меншин не можуть бути відібрані. Однак, Україна робить це саме так.

В Україні 16 липня 2019 року набув чинності Закон «Про забезпечення функціонування української мови як державної». Закон, підписаний Президентом Петром Порошенком 15 травня за чотири дні до завершення його повноважень, виклав безліч питань у відносинах із європейськими партнерами. I йдеться не лише про Угорщину, яка бачить у ньому чергові утиски прав угорської меншини на Закарпатті. Було наперед відомо, що Закон критикуватиме також Свропейський Союз, який багаторазово та наполегливо просив Київ надіслати його на перевірку до Венеціанської комісії. Українська влада відмовлялася це робити, тим самим лише підтверджуючи: автори документа усвідомлюють, що критики Закону не уникнути.

Зрештою, Закон потрапив до «Венеціанки» навіть проти волі України, а 6 грудня та завершила процедуру й ухвалила свої рекомендації. Суть їх у декількох словах така: багато положень Закону не відповідає взятим Україною на себе міжнародним зобов'язанням як у двосторонньому, так і у багатосторонньому форматі.

В угорських масмедіа, зразу після оприлюднення Закону, з'явилося безліч статей, повідомлень, аналітичних матеріалів. Для них загальним є те, що всі вони незалежно від лівої чи правої направленості, провладної позиції чи опозиції гостро критично сприймають будь-які спроби створити перешкоди у використанні угорської мови угорцями, які проживають в Україні.

Нову хвилю обурення угорської влади, наукової спільноти та загалом суспільства викликав прийнятий 16 січня 2020 року Верховною Радою України Закон «Про повну загальну середню освіту».

Усе це також знайшло відображення у ЗМІ Угорщини, викликало негативне ставлення угорського населення до української влади.

Загострення між Україною та Угорщиною у питаннях використання національною меншиною угорської мови у сфері 
освіти і повсякденного життя продовжуються. 29 червня 2020 року заступник Міністра закордонних справ В. Боднар повідомив, що у кінці липня можуть зустрітися Президент України В. Зеленський та Прем'єр-міністр Угорщини В. Орбан. Однак, ця зустріч не відбулася. Про те, коли може відбутися візит Прем’єр-міністра Угорщини Віктора Орбана в Україну, повідомив Посол Угорщини в Україні Іштван Ійдярто. Однак, як зазначив у інтерв'ю виданню «Інтерфакс-Україна» Посол Іштван Ійдярто, візит Віктора Орбана в Україну відбудеться «коли умови дозволять». За словами дипломата, угода про дорожню карту, яка веде до візиту, полягала в постійних розмовах двох Міністрів закордонних справ - Дмитра Кулеби та Петера Сіярто, «які будуть рушіями відновлення або регулювання наших відносин. Вони погодилися, що деякі інституції мають розпочати роботу, щоб ідентифікувати проблеми, відкрити шлях для подальших переговорів, двосторонніх зустрічей». Потрібно зазначати, що при тому, що питання угорської меншини надалі відіграє значну роль у формуванні двосторонніх міждержавних українсько-угорських відносин, питання захисту прав меншин 3 об'єднуючого, цементуючого чинника, яким видавалося у часи початку цих відносин, поступово перетворюється у деструктивну проблему між державами. I, напевно, є найбільш тривожним те, що така атмосфера недовіри з висоти міжурядових стосунків поступово поширюється як у середовищі політикуму, так i громадськості двох сусідніх, безумовно приречених на дружбу й співпрацю сусідніх держав. Українська влада, політикум повинні зрозуміти, з урахуванням угорської історії, що будь-яке угорське керівництво буде проводити політику захисту своєї національної меншини у сусідніх країнах i, у тому числі, у Закарпатті. Це можливо використати на користь України, а, ймовірно, навпаки через безглузду політику - на шкоду. Надзвичайно актуальним є знайдення правильного алгоритму для задоволення освітянських потреб угорської меншини. Тут потрібно враховувати специфіку угорської мови, яка належить до угрофінської мови та входить до уральської мовної сім’ї і повністю відрізняється від української мови. І вимагати від випускників угорських середніх шкіл такого знання української мови, як i 
українських школярів, означає закрити їм шлях до українських ВН3. Необхідно також на державному рівні розробити програму підтримки задоволення культурних, освітянських, мовних потреб угорської національної меншини Закарпаття. Цим самим ми створимо сприятливий клімат в українсько-угорських стосунках, а це, у свою чергу, вплине і на позицію щодо України керівництва Угорщини. 
Вищий навчальний заклад

«Університет економіки та права «КРОК»

\section{Д.І. Ткач \\ Журналістика в Угорщині: загальне та особливе \\ Монографія}

Комп’ютерна верстка: B.I. Гришаков

Підписано до друку 6/07.2020 р. Формат 60x84/16.

Гарнітура Times. Ум. друк. арк. 17,6. Наклад 60 прим.

ВНЗ «Університет економіки та права «КРОК»

Свідоцтво про внесення суб'єкта видавничої справи до Державного реєстру ДК № 613 від 25.09.2001 p.

Надруковано департаментом поліграфії

ВН3 «Університет економіки та права «КРОК»

м. Київ, вул. Табірна, 30-32

тел.: (044) 455-69-80

e-mail: polygrafia.krok@gmail.com 